\title{
BRITAIN, FRANCE
}

AND THE DECOLONIZATION

OF AFRICA:

FUTURE IMPERFECT?

Edited by

Andrew W.M. Smith

and Chris Jeppesen

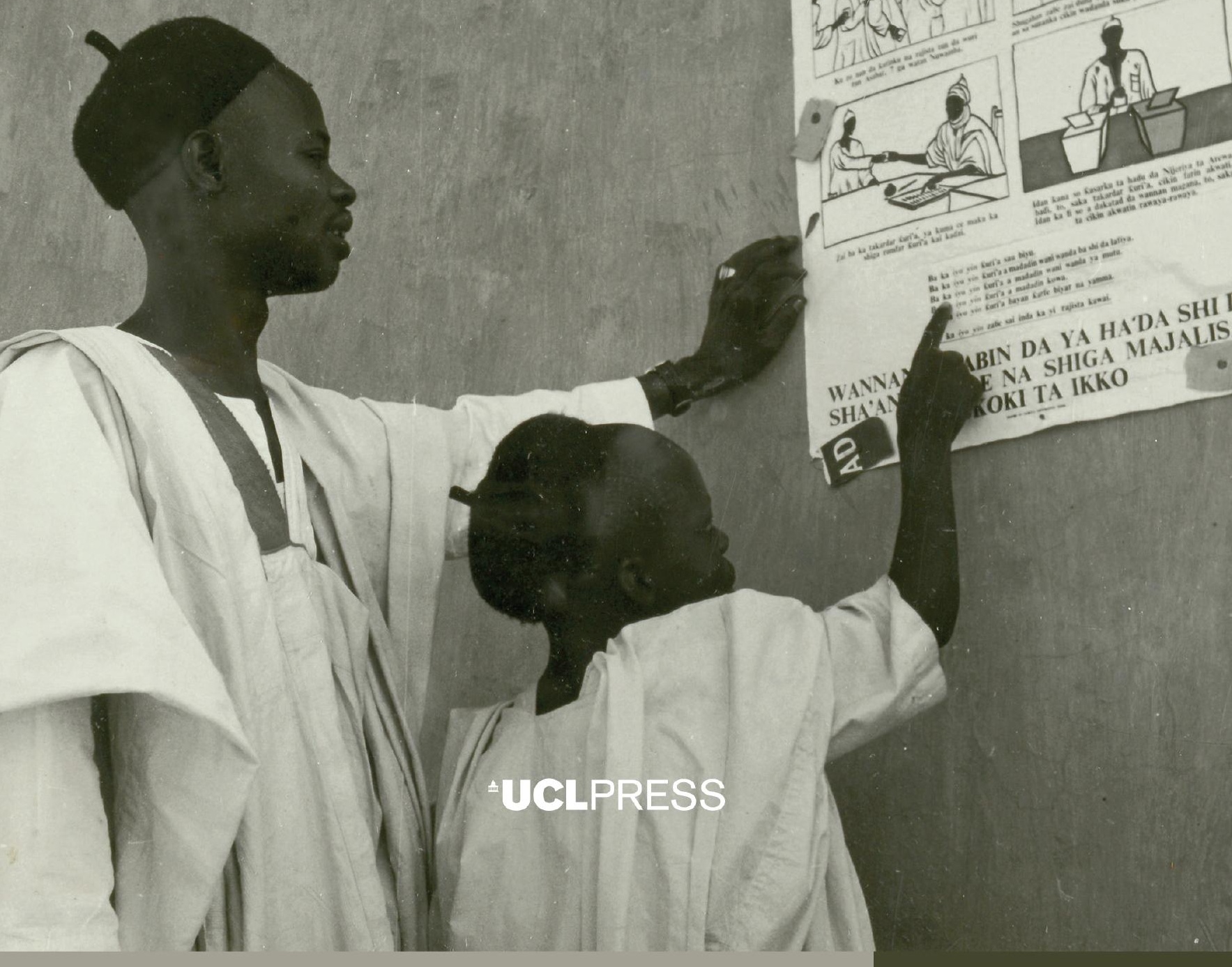





\section{Britain, France and the Decolonization of Africa}





\section{Britain, France and the Decolonization of Africa}

Future Imperfect?

Edited by Andrew W.M. Smith and Chris Jeppesen 
First published in 2017 by

UCL Press

University College London

Gower Street

London WC1E 6BT

Available to download free: www.ucl.ac.uk/ucl-press

Text (C) Contributors, 2017

Images (C) Contributors, 2017

A CIP catalogue record for this book is available from The British Library.

This book is published under a Creative Common 4.0 International license

(CC BY 4.0). This license allows you to share, copy, distribute and transmit the work; to adapt the work and to make commercial use of the work providing attribution is made to the authors (but not in any way that suggests that they endorse you or your use of the work). Attribution should include the following information:

Andrew W.M. Smith and Chris Jeppesen (eds.), Britain, France and the Decolonization of Africa. London, UCL Press, 2017. https://doi.org/10.14324/111.9781911307730

Further details about CC BY licenses are available at http://creativecommons.org/ licenses/

ISBN: 978-1-911307-74-7 (Hbk.)

ISBN: 978-1-911307-75-4 (Pbk.)

ISBN: 978-1-911307-73-0 (PDF)

ISBN: 978-1-911307-76-1 (epub)

ISBN: 978-1-911307-77-8 (mobi)

ISBN: 978-1-78735-003-8 (html)

DOI: https://doi.org/10.14324/111.9781911307730 


\section{Acknowledgements}

This book emerged from discussions at a conference organized by the editors at University College London (UCL) in 2014, which proved an inspiring and productive exploration of the field. We would like to thank all the participants for their input and their insight in shaping the ideas behind this work, as well as the funders of that conference: the Royal Historical Society, UCL History and the Joint Faculty Institute of Graduate Studies at UCL.

In addition, both editors would like to thank Margot Finn for her generous advice and willing guidance during our time at UCL. We are grateful to all the contributors to the volume for making this such an enjoyable and engaging process, while Chris Penfold, our editor at UCL Press, has shown much-appreciated forbearance during the publication process. Holly Smith and Susan Imrie both provided invaluable support, editorial advice and patience during the preparation of the volume. Likewise, we both owe great thanks to Penelope Smith for being born two weeks late and affording us the space to finish writing! 



\section{Contents}

List of figures

Introduction: development, contingency and entanglement: decolonization in the conditional

Andrew W. M. Smith and Chris Jeppesen

\section{Section 1 Development}

1 Nation, state and agency: evolving historiographies of African decolonization

Michael Collins

2 'The winds of change are blowing economically':

the Labour Party and British overseas development, 1940s-1960s

Charlotte Lydia Riley

3 'Oil will set us free': the hydrocarbon industry and the Algerian decolonization process

Marta Musso

\section{Section 2 Contingency}

4 Future imperfect: colonial futures, contingencies and the end of French empire

Andrew W. M. Smith

5 The dynamics of anti-apartheid: international solidarity, human rights and decolonization Robert Skinner 
6 'A worthwhile career for a man who is not entirely self-seeking': service, duty and the Colonial Service during decolonization

Chris Jeppesen

7 Protecting empire from without: francophone African migrant workers, British West Africa and French efforts to maintain power in Africa, 1945-1960

Joanna Warson

Conclusion: the conditional as a category

Chris Jeppesen and Andrew W. M. Smith

Afterword: Achilles and the tortoise: the tortoise's view of late colonialism and decolonization

Martin Shipway

Notes

Select bibliography $\quad 224$

Index 


\section{List of figures}

1 Map of African states with dates of independence 3

2 Map of newly discovered North African hydrocarbon fields, 1962

3 The original marketing material found inside Le Destin de l'Union française

4 The first page of extracts in front of the green folder in the archives at Aix

5 Cornut-Gentille's report 


\section{Notes on contributors}

Michael Collins is Senior Lecturer in International and Imperial History at UCL. He specializes in the history of empire and decolonization. He is the author of Empire, Nationalism and the Postcolonial World: Rabindranath Tagore's Writings on History, Politics and Society (London: Routledge, 2012) and the forthcoming Decolonization and Globalization since 1945 (London: I.B. Tauris). His current research looks at the 'federal moment' in world history after 1945, and the interest shown by anti-colonial intellectuals in constructing regional federations in formerly colonized territories.

Chris Jeppesen is a historian of twentieth-century Britain and the British empire. He completed his $\mathrm{PhD}$ at the University of Cambridge, exploring the motivation behind careers in the imperial civil services, and since then he has worked on the shifting significance of empire within British culture more broadly. He is currently Teaching Fellow at UCL.

Marta Musso is a researcher on the history of the oil industry and international development. Having completed her $\mathrm{PhD}$ at the University of Cambridge, she is currently Max Weber Fellow at the European University Institute. Her fields of specialization include international business history, energy policies, the economics of decolonization and the evolution of digital communication. She has published on the Trans-Mediterranean gas pipeline, Italian-French relations during the Algerian War and the evolution of business websites. She is a fellow of the Cambridge-Harvard Centre for History and Economics and one of the founders of Eogan, the European Oil and Gas Archive Network.

Charlotte Lydia Riley is a lecturer in twentieth-century British history at the University of Southampton. Before this she taught and researched at the University of York, the London School of Economics, and UCL, where she completed her PhD. Her work explores the Labour Party's approach to aid and development from the 1920s to the 1990s. She is interested in 
the end of the British empire, broadly understood, and questions about duty, morality and identity in British politics.

Martin Shipway is Reader in French and European Contemporary History at Birkbeck College, University of London. His work to date has focused on the French empire in Africa and Asia, and he has written a comparative account of European decolonization, Decolonization and its Impact: A Comparative Approach to the End of the Colonial Empires (Malden, MA: Blackwell, 2008). He has published widely on French colonial policy and administration in Africa, Madagascar and Indochina, and is currently working on a project that examines the French 'official mind' during the period of decolonization.

Robert Skinner is a lecturer in modern history at the University of Bristol. His research examines transnational anti-colonial activism in the post-war world, and he has published on the history of the anti-apartheid movement, including his book The Foundations of Anti-apartheid: Liberal Humanitarians and Transnational Activists in Britain and the United States, c. 1919-64 (Basingstoke: Palgrave Macmillan, 2010). His recent work has focused on the interconnected histories of Third World nationalism, pacifism and the global anti-nuclear weapons campaigns of the early 1960s.

Andrew W. M. Smith is a historian of the French and francophone world. His work focuses on concepts of centre and periphery, analysing various contexts in which this relationship has shaped developments within and beyond the structures of the modern state. In this context, he has written on minority nationalism in France and the decolonization of French West Africa. His most recent book is Terror and Terroir: The Winegrowers of the Languedoc and Modern France (Manchester: Manchester University Press, 2016). He is Teaching Fellow at UCL and the secretary of the Society for the Study of French History.

Joanna Warson completed her PhD in 2013 at the University of Portsmouth, under the supervision of Professor Tony Chafer and Professor Martin Evans (Sussex). Her thesis examined French policy in, and perceptions of, the British colony of Southern Rhodesia (Zimbabwe). Between 2013 and 2015 Joanna was Postdoctoral Research Fellow in the Centre for European and International Studies Research at the University of Portsmouth. 



\title{
Introduction: development, contingency and entanglement: decolonization in the conditional
}

\author{
Andrew W. M. Smith and Chris Jeppesen
}

The imperfect tense describes an indefinite ending: in the past, it is irresolute; in the future, it is conditional. In the aftermath of the Second World War, the vast African empires of Britain and France started to break apart in ways that seemed to defy the political will of the colonizers. By 1966 most of the African continent had gained independence and new nation states raised the standards of liberation. ${ }^{1}$ Looking back on the political reconfigurations of this period, it can appear that an unstoppable storm swept across the African continent during the late 1950s and early 1960s. Indeed, leading figures on both sides of the colonial divide regularly chose to remind diverse audiences at this time that events were being propelled by uncontainable, natural forces. Be it through Macmillan's 'wind of change', Nkrumah's 'raging hurricane' or the tides of history washing France out of Algeria, European colonialism appeared destined to be overwhelmed by forces beyond its control. ${ }^{2}$

Yet, as Frederick Cooper astutely reminds us, when explaining the end of European empires in the middle of the twentieth century, historians all too often fall into traps set by knowing how the story ends. ${ }^{3}$ The surety of the destination, however, should not make an arduous journey any simpler in reflection. Whether through violent confrontation or negotiated transition, possibilities for political change grew and shrank in the decades after 1945. There was no straight, single path that led to the end of empire, just as there was never one united voice raised in defiance of colonial rule. ${ }^{4}$ Across many territories the departing pageantry of colonial authority, typified in its last moment in the folding up and unfurling of flags, invoked a sense of order and control that was seldom 
in evidence as those ceremonies were conceived. ${ }^{5}$ New 'developmental' initiatives after 1945 profoundly changed the relationship between local people and the colonial powers. They generated new opportunities for negotiation, opened spaces in which claims could be made upon the state and provoked bitter challenges that pushed against the limits of colonial authority. The outcomes of these encounters were not preordained; unforeseen consequences created contingent moments in which the process of political change became redirected. ${ }^{6}$

The chapters in this volume coalesce around three central themes of development, contingency and entanglement to explore when and why such possibilities emerged, and also chart their disappearance during the period of 'late colonial shift' from around 1945 to $1970 .{ }^{7}$ Sifting through the complicated processes that shaped decolonization permits us to account for, to measure and to analyse the messiness and fluidity so often flagged up as beyond the terms of study. Cutting across traditional chronological frames allows us to look askance at the process of decolonization, and to consolidate different historiographies. Visions of the future were conceived in the conditional tense, and give us the sense of a future imperfect. These drew upon connections, movements and ideologies that had started to form during the interwar period but that were intensified and transformed during six years of global conflict. ${ }^{8}$ Profound political, economic and cultural developments in Europe and Africa inflected the imperfect visions of the future that arose, and make this period especially significant in understanding the end of European empires in Africa.

Decolonization resists easy definition or periodization. Like the process itself, writing the history of decolonization in Africa remains fraught and contested. In its shallowest and narrowest form, decolonization refers to the transfer of sovereignty from colonizer to colonized. Even though political and economic entanglements endured, the transfer of power represented a moment of profound realignment. This seemed to invite the view on both sides that the process had always been inevitable. For European powers, self-congratulatory Whiggish proclamations celebrated a job well done. ${ }^{9}$ In contrast, within newly independent African nation states, narratives of national liberation celebrated hard-won independence as the foundation myth for new national histories, born of struggle and achieved through the victory of nationalism over colonialism. These dichotomies quickly crept into initial retellings of the end of European empire, drowning out alternative narratives. Politicians and commentators emphasized points of fracture over enduring continuities, while scholars, often with one eye on the present, settled into arguments about whether independence was given, taken or inevitable. 


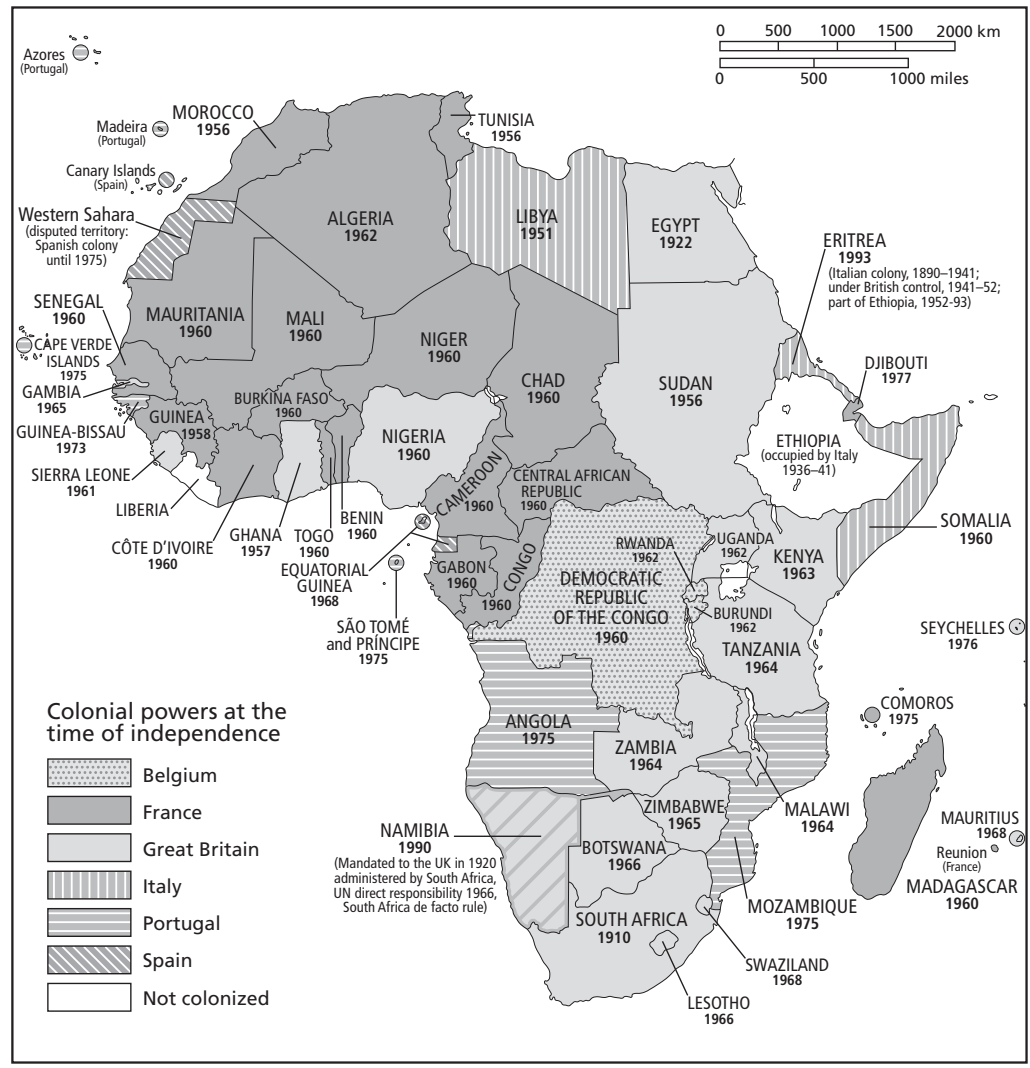

Figure 1 Map of African states with dates of independence

Over the previous two decades the field of decolonization studies has been transformed. ${ }^{10}$ Rather than focusing on shallow flag independence, explorations of deep decolonization range far beyond questions of territorial sovereignty, ${ }^{11}$ instead exploring what Senegalese poet and politician Léopold Senghor has called 'the decolonization of minds'. ${ }^{12}$ Entrenched binaries and teleological assumptions have been broken down, and smooth narratives running towards an inevitable end point disrupted. This is what Michael Collins explores in Chapter 1, which traces a number of important trends in the historiography of decolonization. Collins' in-depth historiographical survey is intended to stress the importance of perspective and highlight the ways in which discussions of decolonization have been shaped by their contemporary contexts. Issues of agency, discussions of legacies, and the compact of the imperial nation state all offer rich seams for interrogating the ways in which the end of European empires has been framed by historians. What emerges 
is a messy, contingent and contested constellation of intersecting and often competing processes, which cut across local, national, imperial and global contexts. Such distinctions were familiar to African opponents of colonial rule in the late 1950s. For Senghor, decolonization had to involve more than the transfer of political power. Writing in Le Monde in 1957, he explained: "By decolonization, I mean the abolition of all prejudice, of any superiority complex in the minds of the colonizer, and also of any inferiority complex in the mind of the colonized. ${ }^{13}$ Colonial authority never rested on juridical control alone. Its perpetuation depended upon complex systems of knowledge and power that facilitated the physical, racial, economic and linguistic subordination of colonial peoples. ${ }^{14}$

One of the great challenges of explaining late twentieth-century decolonization in Africa is how to capture the diversity of local particularity while threading this into a coherent overarching narrative that situates the broadly contemporaneous breakdown of European empires amidst the turbulent currents of post-1945 global politics. To achieve this, Martin Shipway has elsewhere stressed the need to triangulate "between "top down" and "grass roots" perspectives, and by comparing the various colonial empires [to] arrive at that curious entity known in the literature as the "colonial state". ${ }^{15}$ For Shipway, the colonial state was the prize for which colonial governments and nationalist opponents fought. Likewise, for John Darwin, the very idea of its 'lateness' changed the nature of the compromises struck between the colonized and colonizers, as broader global pressures met an ever denser mesh of local conflicts. ${ }^{16}$ By focusing on the colonial state not as a manifestation of European control but as a composite of competing systems of power, structures of sovereignty and channels of interaction, we can understand it as an unruly space in which divergent ambitions could be pursued. ${ }^{17}$ This encourages an analytical approach that is more openly comparative, allowing us to break down the conceptual borders of formal empires and recognize the resonance of British and French attempts to impose authority over a wealth of local communities and nations anew, while trying to resist the wider processes that eroded the basis of colonial legitimacy during the twentieth century. While these acted upon different empires in uneven ways, and provoked often drastically divergent responses, they offer, in Martin Thomas' formulation, new insight into how colonial powers decided between 'fight or flight'. ${ }^{18}$

By the late 1950s most observers recognized that significant change loomed on the horizon. Following Britain and France's humiliation during the Suez Crisis, a new confluence of pressures emanating in the metropole, colonies and wider international arena ensured that maintenance of the status quo could satisfy very few. For metropolitan planners, colonial 
resources and markets had not generated the desired boost to stuttering European economies, and, with anti-colonial agitation mounting, the costs of maintaining an empire rapidly appeared to be outstripping the benefits. ${ }^{19} \mathrm{~A}$ series of brutal confrontations between colonial authorities and local opponents across Africa and Asia highlighted the fragile foundations of European authority, whilst the rise of mass nationalist movements in many territories generated new expressions of a popular will for racial and political equality. ${ }^{20}$ These calls were amplified within global institutions and Cold War configurations, which provided new forums and vocabularies to strip colonialism of any lingering ideological legitimacy. ${ }^{21}$ And yet, even at this stage, few could confidently predict how long or what shape this transformation would take. ${ }^{22}$

This volume draws out the interplay between cultural, political and economic forces within and between European decolonization in Africa during the period of late colonial shift. Frederick Cooper has led this trend, focusing on 'the pushing and tugging at colonial relationships' and stressing the importance of the febrile period of decolonization over the assumed narrative of colonial decline. ${ }^{23}$ At both the level of the state and below, this was a process as defined by its lingering entanglements as it was by fundamental changes to formal structures. For metropolitan audiences, decolonization did not simply unfold elsewhere. As Elizabeth Buettner lays bare, it helped reconfigure European societies in fundamental ways. ${ }^{24}$ In capturing the fluid relationship between 'metropole and colony', Gary Wilder has reframed France as an 'imperial nation state', expanding the frame of reference to look beyond a hexagonal view of its colonial relationships, and privileging the nuanced and often messy transfers between politics, activism and the arts. ${ }^{25}$ In service of this understanding, the chapters in this volume consider micro-histories, memories and transnational debates, all of which are situated within the years around the end of empires. They chart a multiplicity of transformative forces within and beyond colonial borders, recognizing where processes were bound by geographic limits and where they spilled over. ${ }^{26}$ In considering these messy moments of late colonial tension and transformation, this volume develops three main themes: development, contingency and entanglement.

\section{Development}

Far from initiating a retreat from empire, the experience of the Second World War made European powers more determined to reinvigorate their African colonies in new ways. Post-war reconstruction at home would be matched by a restructuring of empire overseas. War 
had sapped European powers' economic and physical strength, but, more decisively, also undercut the moral basis of empire itself. ${ }^{27}$ In the aftermath of the war, and amidst the crystallizing polarities of the Cold War and the first wave of decolonization in Asia, the cacophony of voices raised in criticism of European empire grew in volume and number. ${ }^{28}$

A generation earlier, the Wilsonian moment's apparent promise for colonial peoples had dissipated amidst repressive coercion and brutal reprisal. ${ }^{29}$ In contrast, as Emma Hunter has explained, the period between the pronouncement of the Atlantic Charter (1941) and the United Nations' Universal Declaration of Human Rights (1948) 'marked a rupture in traditions of international political thinking. ${ }^{30}$ New international institutions enshrined self-determination as a universal goal, while a discourse of universal human rights threw the essential contradictions of imperial power into stark relief on a global stage - processes explored by Robert Skinner in Chapter 5. In consequence, European powers accepted that a return to the orthodoxies of the interwar years was no longer sufficient. In place of the old axioms of indirect rule, trusteeship and the mission civilisatrice, colonial development was placed at the heart of a reconceptualized colonial project. While ideas of colonial development had long roots reaching back to the nineteenth century, the post-1945 iteration seemed to mark a decisive shift that was both practical and discursive. ${ }^{31}$ Development became a lens through which diverse groups sought to spy very different futures; it was never monolithic in meaning, intent or outcome. As such, development initiatives created a web that spanned metropolitan and colonial contexts, and incorporated state and non-state actors. In revealing the gap between ideology and practice, development exposes the interplay of high politics, structural change and popular response. ${ }^{32}$ It offers an insight into the underlying dynamics of the late colonial shift and the contingent processes that shaped the final breakdown of European empires in Africa, as well as situating these within a wider Cold War context. ${ }^{33}$

Although reforming voices had been calling for greater intervention by the colonial state to tackle the problems of hunger, poverty, exploitation and disease since the 1930s, it was not until after the war that the resources required to realize these ambitions became available. Swept up in post-war optimism, metropolitan planners fervently proclaimed the potential for science and technology to deliver material improvement to both European and colonial societies. Few saw any contradiction in deploying technocratic expertise to improve standards of living and 
productivity through 'welfare' at home or 'development' in the colonies, while simultaneously boosting metropolitan economies. Although it was never confined to those on the left of European politics, this redemptive vision for empire, as Charlotte Riley documents in Chapter 2, found enthusiastic advocates in the British Labour Party. Riley stresses that for some members of Attlee and Wilson's Labour governments developmentalism came to define the transition from Empire to Commonwealth, even if that definition was not always meaningful for recipients of aid or decolonizing peoples. Colonial development schemes facilitated a reimagining of the relationship between colonial powers and colonized territories in the years after 1945, which created new forms of influence to protect key interests after the end of formal rule. The Labour Party emerges as a means of tracking changes in an evolving discourse of humanitarian aid, which had its roots in post- 1945 colonial development. This analysis stresses that the humanitarian work of the 1960s and onwards reflects the ways in which Labour ministers attempted to imagine an alternative colonial future in the aftermath of the war.

Far from constituting an expression of colonial hegemony, post1945 development remained a contested and contingent process of negotiation between European governments, colonial officials, commercial interests and local people. ${ }^{34}$ In Chapter 3, Marta Musso analyses the complexities of decolonization in relation to resource competition. By focusing on the discovery of oil in the Sahara, another aspect of the complex entanglement of empire is revealed. The interaction of states and non-state actors complicated negotiations considerably, drawing together conflicting partners and forcing political solutions to follow the impulses of business. Musso's chapter reconstructs a series of negotiations in which sovereignty and capital were crucial but uncertain. This offers a compelling illustration of how visions of the future could shape negotiations, and how development was contested and multidirectional. While the Algerian National Liberation Front (FLN) bartered off rights to those whom it could support, the French state sought to undermine North African solidarity by dealing with the Tunisians. A turbulent global political situation acted as a backdrop for these negotiations, in which the Suez Crisis and the 'battle of Algiers' served as vital considerations for the money men looking to invest in a viable future and French officials hoping to secure access to valuable resources. These multiple contingent judgements shaped the experience of development, and spanned the network of entanglements that criss-crossed the late colonial state.

In formulating their vision of a technocratic revolution, metropolitan bureaucrats took little account of how individuals and groups across 
Africa were also reimagining the possibilities for change now open to them. But indigenous populations never sat passively by while colonial officials remade the world around them. ${ }^{35}$ Local responses displayed understandable mistrust at attempts to interfere in established agricultural practices and the intimacies of domestic life. ${ }^{36}$ Lamenting such an attitude, Senghor said of late colonial development policy: 'The people of the overseas territories are more sensitive to the means of giving than the gift itself. More precisely, the problem is not the giving, but to discuss the gift between partners in the communauté on an equal footing. ${ }^{37}$ Colonial officials were left with little option but to pursue a pragmatic approach based upon negotiation and conversation, rather than compulsion, in order to achieve any impact at all. Even so, the reliance on violent coercion as a means of imposing order did not diminish. ${ }^{38}$ Events in Kenya and Algeria may provide the starkest reminder that the ending of empire could depend upon a brutal bloodletting, but this should not detract from the everyday forms of popular and political violence seen across almost all decolonizing territories. ${ }^{39}$

Development initiatives not only impacted on the physical landscape of colonial territories, they also asked (and often demanded) that Africans thought about themselves in new ways. ${ }^{40}$ After 1945 development sat alongside human rights as an emancipatory discourse. ${ }^{41}$ In recognizing colonial subjects' right to make demands upon the state, colonial powers opened a dialogue that, as Skinner explores in Chapter 5, African leaders would take in unforeseen directions, and in so doing create new possibilities for political transformation. In appropriating the language of development to make their own claims upon the state, African trade unionists, farmers, mine workers, ex-soldiers and politicians, as well as many ordinary men and women, demanded that colonial governments make good on abstract promises by delivering equality of pay, education, rights, welfare services and political reform..$^{42}$

Unsurprisingly, developmental colonialism never realized the beneficent promises many European officials liked to proclaim; neither did it equate to unbridled exploitation, however. ${ }^{43}$ Britain and France both continued to actively extract economic, strategic and diplomatic benefits from the grossly unequal relationships of empire, but they also embarked on a far-reaching series of interventions that created new opportunities for further change. Development initiatives infringed on the lives of indigenous people in new and increasingly intrusive ways. They opened alternative possibilities for political collaboration, participation and contestation that unfolded in unpredictable ways in the decades after 1945. It was this uncertainty that meant that, even in the mid-1950s, the shape and the 
extent of self-government remained ambiguous in many territories, and predictions of the future remained imperfect. ${ }^{44}$

\section{Contingency}

Contingency, as a tonic for inevitability, has become an increasingly important consideration when writing about the end of empire. It is a concept that is both vital in the possibilities it creates and ephemeral in the uncertainty it engenders. It invokes the conditional tense, and the sense of an ending, but avoids the surety of known outcomes. In prioritizing an anti-teleological reading of decolonization, this sense of the 'future imperfect' is a revealing lens through which to view the present of the past. By sifting through the conditional sense of what would, could and should have happened, we can find a new insight into how those projections of colonial futures were formed.

In Freedom Time, Gary Wilder unpacks how the perception of historical time and the projection of colonial futures energized anti-imperial activists just as it panicked national governments. ${ }^{45}$ The shifting scales of this 'freedom time', perceived during this moment of accelerated change, were both scalable and palpable. Administrators, activists and ordinary people not only conceived of different futures but held different understandings of time. ${ }^{46}$ When colonial administrators articulated the idea of - ever-diminishing - 'timetables for self-government', they were trying to impose order on the competing and clashing pressures that were reshaping the colonial relationship. ${ }^{47}$ The contestation over shaping these was more than a battle over specific points of change and the minutiae of detail; it was also a contest over the control of time. The perspective gained from looking back after the end of empire 'glosses over the contingency and sheer complexity of major historical crises, and the extent to which the impact of crisis led the actors involved to recast their actions retrospectively in terms of the "wider" historical picture'. ${ }^{48}$ Historians are often trapped by the timetables preserved in archival records, in which taxonomy seemingly leaves little room for chance. ${ }^{49}$

The 1950s, in particular, were a period of profound social, cultural and political crisis. There is both a historical and a historicized meaning to this idea of late colonial crisis. When writing about the history of decolonization, the 1950s signify, as Reinhart Koselleck terms it, 'a historically immanent transitional phase'..$^{50}$ The experience of profound change augmented the expectation of further change in the present. By looking at the 1950s as a moment of crisis, we can begin to unravel the mindsets that 
met the oncoming change. Yet there was also a contemporary reading in which events were pushing towards a moment that meant action, or some other reckoning. This destination was neither defined nor delimited by those responding, though it became clear that European empires could no longer exist as they had done for the previous half-century. Opportunities and threats were assessed in the context they arose, and in the late colonial state they seemed to many to augur some grand realignment. Untangling the historical constellations of those in the midst of this crisis (both real and imagined) allows us to better understand the crisis itself. Michael Collins has observed how the 'compression of the historical space between empire and nation-state' transformed alternatives and recast narratives while they were still being written. ${ }^{51}$ The broad 'horizon of expectation', as it was imagined by anti-colonial nationalists, administrators or the innumerable individuals of the British and French imperial nation states, stretched out far beyond what they had seen in the late colonial 'space of experience'. ${ }^{52}$ An anti-teleological reading allows the reconstruction of the ideational contexts in which people found it meaningful to explore alternatives, question their relationships to power and parse everyday impressions, whatever the outcome.

This sits uncomfortably with a narrative of inevitable decolonization, largely defined by the loud voices that echoed after the transfer of power. Looking at alternatives in their contingent context prioritizes different voices, and changes the tenor of their speech. Conditional readings conjure up nuance and uncertainty often lost to the seemingly definitive past. The poetry of Guinean artist and politician Keïta Fodéba provides a useful example. ${ }^{53}$ His poem 'African Dawn' was originally released in 1950, in a collection called Poèmes africains. From this point, Fodéba followed an impressive artistic trajectory that took his troupe, the Ballets Africains, all across the globe. In 1958 he became the interior minister of the newly independent Guinea, helping to define its culture and its systems of government, as well as its climate of brutal internal repression and the infamous prison at Camp Boiro. At this stage his work remained popular, as the 1965 reissue of his poetry attested. This revised edition contained important changes, however. Five words were added to the poem 'African Dawn': the line 'Yes, it was the dawn' became 'Yes, it was the dawn... the dawn of African freedom'. The act of alteration changes the character of the book itself, and imbues it with a certainty absent from the original. Fodéba was an artist long before he was Sekou Touré's red right hand. By recognizing and reconstructing these changes, we can salvage a contingent moment from oblivion, and better understand its context. ${ }^{54}$ Without privileging a dominant narrative, such as the coherent 
demands of strident anti-colonial activists or the defence of imperial loyalists, it becomes more possible to look at the contemporary history of the past, and to offer some analysis of the "quixotic space of premonition, probability, and speculation'. ${ }^{55}$ In this volume, a focus on the conditional offers a better means to triangulate competing perspectives in the late colonial state, and better understand the messy and many-layered process of decolonization.

In Chapter 4, Andrew W. M. Smith offers a vision of how the idea of contingency can be read into moments of indecision. By highlighting the simple, but crucial, element of uncertainty, we can read a different narrative in the viewpoints of contemporary actors. This chapter analyses three documents in historical context, while reflecting on the research stories that support them: a book by an academic bound to empire, extracts from African students' homework gathered by the colonial state, and a report by a colonial administrator at the end of his service. In each case, an anti-teleological reading of decolonization is combined with a material history of the source, and a reflection on the background of the authors. Recreating these ideational contexts allows us to recast the issues of the day on the day. Refocusing the narrative, in this social history of ideas, is not intended to supplant grander narratives but, rather, to illustrate the personal and intangible connections that supported the imperial nation state.

Beyond moments of indecision lay longer debates, which addressed the futures of African states and their people in a similarly contingent fashion. In Chapter 5, Robert Skinner analyses how the terms of human rights talk emerged out of a responsive relationship with their context, dependent on the many contingent turns of the decolonization period. This chapter looks at international anti-apartheid activism in the 1950s and 1960s, to examine in particular the vague and diffuse sense in which ideas of 'human rights' were deployed by activists. The definitions of 'human rights' that became dominant in the 1970s did not emerge from a static vision espoused by utopian radicals, nor was it a post facto imposition by colonial states but, rather, an illustration of how 'pushing and tugging' shaped the processes and discourses of politics in colony and metropole. Ideational contexts were not always static, nor easy to trace, and this chapter cuts across horizontal and vertical bonds to analyse a transnational discourse shaped by the 'freedom time' context of the late colonial state. ${ }^{56}$ Through this framework, individuals and groups sought new ways of mobilizing political protest, modes of action and participation in the light of decolonization. 'Solidarity' against apartheid, while resonant with older forms of liberal and socialist internationalism, 
developed in parallel with attempts to promote new forms of political engagement that transcended national borders - just as these borders increasingly came to mark, define and demarcate newly sovereign territories.

\section{Entanglement}

The transfer of sovereignty to successor governments may have marked the end of formal control, but widespread entanglements remained at both the level of the state and below. ${ }^{57}$ European non-governmental organizations (NGOs), businesses, charities, mercenaries and many others stepped into the spaces left by the retreating colonial state, often replicating previous inequalities of power in new forms. In recognizing the particular importance of post-war developmental impulses, and the contingent influence of perceived and anticipated change, the entanglements of the late colonial state are given fresh importance in this volume. This was not simply the product of neo-colonial exploitation but a more fundamental recasting of connections. The end of formal rule did not rend the relationship between Europe and Africa but simply unpicked some of the threads in a densely woven cloth. Many European officials in the late 1950s would have appreciated this view. Although they were increasingly prepared to accept that the end of formal control was becoming ever more likely, few believed this should necessitate a profound realignment in the relationship between Europe and Africa. ${ }^{58}$ As in Lynn Hunt's understanding of globalization, decolonization can be understood as a 'series of transnational processes in which the histories of diverse places become connected and interdependent'. In this iteration, decolonization is not a single coherent process but a multifaceted combination of forces working towards the dissolution of all vestiges of colonial domination, whether they were material, ideational, psychological or structural. Far from having ended with the passing of sovereignty, it remains ongoing. ${ }^{59}$

Decolonization's effects rippled far beyond the borders of newly independent states, to reconfigure European societies and global political thinking just as profoundly. ${ }^{60}$ For Todd Shepard, this took shape in French culture as a means of dealing with the trauma of imperial dislocation. ${ }^{61}$ Shepard's reading brought the importance of personal connections and interpretations to the fore, and discussed how opinions and narratives were constructed in public discourse. This is especially useful when considering those bonds that stretched beyond France itself and followed families, companies and relationships across the routes of empire. 
In Chapter 6, Chris Jeppesen offers another vision of entanglements that adapted to the end of formal rule, and sought to reforge themselves outside state control, yet still within the compact of the imperial nation state. Jeppesen's chapter addresses the reformulation of duty and service, reconfiguring imperial loyalties around individual aspirations and trajectories. In a parallel of the personal bonds and connections sketched out by Wilder in the French imperial nation state, the British Colonial Service and its recruits experienced a complex mixture of continuities, dislocations and reconfigurations. Many connections survived the formal transfer of power, proving adaptable and taking on the language of development to foster engagement in newly independent African states.

A drive to understand better how decolonization reveals fresh perspectives on the dynamics of power, agency and political reconfiguration across time and space has led transnational and global historians to move beyond a focus on the breakdown of twentieth-century empires. Rather than seeing this as a phase of late modernity unfolding within national history paradigms, they have instead used it to ask new questions about processes of global change and exchange from the late eighteenth century until the present. ${ }^{62}$ Central to this has been an approach that not only compares national empires but charts the flows between them. ${ }^{63}$ Joanna Warson's focus on entanglement in Chapter 7 teases out a meaningful discussion of how shared experience could shape visions of the future. British and French colonial officials struggled to contain West African populations that moved freely across colonial borders, even as they attempted to legislate around them. French officials feared that migrating workers would weaken their claims to developmental legitimacy, sensing a loss of manpower and prestige as people moved in search of work. Such negative assessments seemed to increase the likelihood that nationalist ideals would spread, and French officials worked to these predictions. These worries about what could and should happen encouraged the French to reach over porous borders, engaging directly in anglophone Africa and fostering increasing entanglements as a result of the shifting sands in the late colonial state.

Envisaging European empires as overlapping webs of exchange, across which travelled people, resources, capital and knowledge, has transformed understandings of how colonialism operated from the eighteenth century onwards. ${ }^{64}$ Decolonization, in this reading, is far more than an account of the ending of European empires. It is a globalizing force in its own right, which compresses gulfs of time and space to make possible new political configurations and imagined communities. ${ }^{65}$ Indeed, this volume recognizes Potter and Saha's call for a reconciliation 
of global and imperial history, and sets out with the intention of affording 'more agency to individuals, and recognis[ing] the crucial importance of choice, contingency and chance'. ${ }^{66}$ Imperfect visions of the future could draw on connections that cut across the colonial state just as they could reinforce some of the structures designed to manage it.

\section{Concluding comments}

The developmental turn of post-war empires was an important marker of change. By reconfiguring the relationships that spoke through the compact of the late colonial state, it relied on the triangulation of perspectives that this volume will explore. This change took place in contexts that were marked by a pervading sense of crisis and opportunity, however. This moment of possibility magnified the potential for change, and the relationship between space of experience and horizon of expectation was notably uncoupled. In this context, the entanglements of empire gained a new importance in configuring structures of power and motivating action in a postcolonial world. Sovereign borders could not contain the discourses that recast them, nor hope to stymie the developing appetite for their revision. Actors beyond the confines of the state acquired more prominent roles in defining the direction of newly independent nation states.

The processes described are not intended to be comprehensive but, rather, to serve as an exploration of emergent historiographical themes in a febrile setting for historical enquiry. By uniting different historiographical fields (both geographically and in terms of approach), this volume stresses the importance of the particular period of late colonial shift in understanding the complex relationship between Europe and Africa as the process of decolonization unfolded. It seeks to shed light on a moment of adaptation, in which confident projections of future developments were conceived even while the structures they relied on were reconfigured around them. In tackling the notion of human rights or development, anti-colonial activists and colonial officials alike drew on an ideational context that they were struggling to control. The forces of history, so evident in the vocabulary of the colonial leaders and European governments in the 1950s, were never as unitary, nor as simple as they were depicted. Rather, they converged on an imperfect future, conceived conditionally on bargains yet to be struck, and debates yet to be won. 
Section 1

Development 



\title{
Nation, state and agency: evolving historiographies of African decolonization
}

\author{
Michael Collins
}

As the title of this volume suggests, scholars of decolonization are increasingly looking at the connected or 'entangled' histories of empire and its aftermaths. From this perspective, decolonization was not a discrete process that marked a shift from empire to national independence but a multi-layered, multifaceted phenomenon. While decolonization had particular, specific causes and effects in different African settings, it was also shaped by wider, structural dimensions of empire that may be seen as systemic: the political and economic relationship between imperial 'core' and colonial 'periphery'; the colonial state in terms of its bureaucratic structure; ideologies of governance, 'development' and race; and emancipatory narratives of anti-colonial freedom and nationhood. Many of these aspects of empire and decolonization cut across particular imperial or national contexts and point us towards complex chronologies of change.

Looking back at the historiography of decolonization, we are reminded that it has been studied from quite different perspectives, and that this in turn has a strong bearing on the forms of agency that historians of decolonization have placed at the forefront of their analyses. For example, there is a somewhat paradoxical affinity between older accounts of decolonization, which see primary decision-making as taking place in the realm of high politics at the centres of empires, and the newer 'postcolonial approaches'. In the latter case, whether discussing economic theories of dependence and neocolonialism or cultural histories of European imperialism as an intellectual/cultural matrix, Europeans remain central to the exercise of power, control, change and continuity. When historians 
have emphasized African agency this has often (though not always) been within the framework of anti-colonial nationalism.

This is perhaps indicative of the fact that we are revisiting a problem that has concerned historians of empire for a long time: how to write the history of empire - or of decolonizing empires and new states - as a more or less integrated field of study. The focus on the 'entangled' nature of imperial aftermaths in this volume suggests that our understanding of when empire ended needs to be questioned and re-examined. The idea that empire continued in alternative forms after formal independence was gained is hardly new, but there is an awful lot more to this idea than was originally intended by protagonists of 'neocolonialism'. From a contemporary, 'presentist' perspective, the arguable failures of the postcolonial state in the formerly colonized world require us to look again at independence and its shortcomings. Recent studies have sought to question the empire/nation binary and re-examine the alternative decolonization paths that were not followed. ${ }^{1}$ In addition, historians have begun to pay far greater attention to ongoing postcolonial 'traumas' - specifically, cultural, intellectual and political - in former colonial metropoles. In all these respects, the relationship between the formerly colonized world and the European ex-colonial powers remains deeply interwoven.

\section{Imperial designs, metropolitan manoeuvres and moral legacies}

The older historiography of British and French decolonization has concerned itself with the question of how and why metropolitan political actors deemed it necessary to wind down their empires, and what this signified. In this sense, it has tended to take a metropolitan, or what is often more critically labelled a 'Eurocentric' perspective. The source of explanation for imperial contraction - as with its prior expansion was to be found in the political and economic sphere of decision-making at the centre of the empire. Even where the focus of study extended to colonized territories, the causal relationship moved from core to periphery. African agency eventually manifests itself in the form of a 'nationalist consciousness', whereby colonial elites at the metropolitan centre are able to negotiate a 'transfer of power' to newly independent nation states, ordinarily falling within a post-imperial power structure such as the British Commonwealth or the French Communauté of African states. Along the way, empire and decolonization are both 
bound up with a moral mission and continue to provoke questions about the legacies of empire.

From its earliest incarnation, imperial history was concerned with the expansion of European empires overseas, and as such the history of the colonized world became coterminous with the expansion of European territories and the incorporation of new lands and peoples into imperial structures of control. ${ }^{2}$ European colonization was the integrating force that brought the non-historical peoples of the world into the orbit of history itself. Although decolonization was not yet part of the lexicon of imperial historians, the question of nationalism was not entirely absent from the purview of interwar historians of empire. ${ }^{3}$ The end of the First World War had seen the British empire acquire new mandate territories, but also be challenged by a series of shocks arising from the emergence of nationalism in Ireland, Egypt, Iraq and - most importantly - India, as well as a new assertiveness from the dominions, notably Canada. They were writing at a time when imperial control appeared to be increasingly challenged, yet largely retained a confidence in Britain's ability to direct events and the trajectory of empire regardless of local challenges. ${ }^{4}$

From this broadly liberal perspective, not only was there no existential crisis of British imperialism, there was also a widespread belief in its moral purpose, its ongoing 'civilizing mission'. Challenges to British rule were natural developments along the road towards a British Commonwealth, which provided the ongoing justification for the British empire itself. Independence, when it came, would mean the steady achievement of 'free association', but this freedom was not something that colonized peoples would wrench prematurely from the grasp of an oppressive imperial power; it would be negotiated and given when they proved themselves ready. ${ }^{5}$ The focus for these historians of empire was predominantly constitutional. The 1917 Montagu-Chelmsford Declaration on India, and the subsequent 1919 Government of India Act, placed great faith in the possibilities of constitutional reform and gradual democratization. While this spirit of gradualism was to animate much of the interwar historiography on empire, the Second World War forced Britain into a more defensive, self-justificatory position with regard to its empire, and to more explicitly imagine its end. In his 1943 Argument of empire, aimed at US audiences sceptical of Britain's imperial status and intentions, Keith Hancock claimed that the British empire was the most extensive system of freedom that had ever existed in human history. Within the British empire, he wrote, 'monarchy grows into democracy, empire grows into Commonwealth, the tradition of a splendid past 
is carried forward into an adventurous future'. This was contrasted with what he evocatively labelled a 'sundered world of snarling nationalisms'. ${ }^{6}$

Similar interwar positions were also clearly discernible across Britain's political spectrum, albeit with a much clearer accent on 'development' and the socio-economic dimensions of future independence. Following Lord Lugard's Dual Mandate in British Tropical Africa (1922), the idea of 'indirect rule' - whereby local authorities would be preserved and colonial administrations govern through them, envisaging no significant social change along the way - was the paradigm for imperial governance not just for the British but more widely across Africa and beyond. In the interwar research of crucial figures such as Lord Hailey, as well as the large output in both the academic and popular press by Margery Perham on colonial development, we start to see the Lugardian orthodoxy questioned, and the significance of socio-economic change as a prerequisite for future decolonization come to the fore. It has been suggested that this intellectual emphasis on the social and economic underpinnings of 'detribalization' as a preparatory move towards independence pre-dates the Second World War in the form of the colonial development secretary in 1938, Malcolm MacDonald. In that year MacDonald asked the summer school on colonial administration at Oxford University: '[W] hat is the main purpose of the British Empire?' He answered that it was

[t]he gradual spread of freedom amongst all His Majesty's subjects, in whatever part of the earth they live... The spread of freedom in British countries overseas is a slow - sometimes a painful - evolutionary process [which had already resulted in the dominions evolving as 'completely free' and 'fully sovereign nations']... The same spirit guides our administration of the colonial empire. Even amongst the most backward races of Africa, our main effort is to teach those peoples to stand always a little more securely on their own feet. ${ }^{7}$

Bringing freedom as national independence onto the horizon for colonial Africa was something of an innovation in official circles. What is more striking, though, is the deep structural similarities of teleological thinking across the political and academic spectrum in Britain at this time. Empire was not a purely instrumental project, but a moral one directed from the centre. ${ }^{89}$

In historical scholarship, the transfer of power model - in which 'imperial design' explains not only empire's expansion but also its dénouement - held currency for some time, particularly for the generation that 
lived through the Second World War. ${ }^{10}$ For those on the left or centre-left, the imperial development and modernization efforts of the immediate post-war Labour government under Clement Attlee were matters of political and intellectual interest, a practical approach to social and economic change at home and in the empire. The more sympathetic readings speak of what is described as a 'conscious effort' on the part of the British 'to contain, if possible to collaborate with, and ultimately to transfer power to the accelerating force of African nationalism'. ${ }^{11}$ Accounts of this moment of post-war modernization could also be highly personal, bound up as it was with the hopes and aspirations of a generation of soldiers, scholars and reformers who struggled together and believed in the project of a 'new Jerusalem'. Echoes of this are to be found in Ronald Robinson's confident account of the role of Sir Andrew Cohen (permanent undersecretary at the Colonial Office alongside the Secretary of State, Arthur Creech Jones, and a key architect of Labour's plans for colonial reform) as the 'pro-consul of African nationalism'. ${ }^{12}$ Robinson wrote openly that Andrew Cohen was a friend, and he had in fact worked under Cohen as a research officer in the African Studies Branch of the British Colonial Office from 1947 to 1950, and later as chairman of the Cambridge conferences on development from 1961. These historiographical positions have been very much revised by more contemporary studies, but again we see the persistence - across the political spectrum, across interwar and post-war periods and well into the age of decolonization itself - of a Whiggish teleological view of empire as a pax Britannica and decolonization as a benevolent British-led project, whether constitutional or socio-economic, or both. ${ }^{13}$ Directed from the centre, featuring very little African agency at all, decolonization meant the flowering of empire's liberal, progressive seed. ${ }^{14}$

If the historiography of French Africa's decolonization has been overshadowed by the more dramatic and violent confrontations in French Indochina and Algeria, there was nonetheless a palpable French belief in a pragmatic 'managed decolonization' in sub-Saharan Africa - structurally similar though not identical to the British vision - that manifested in the Brazzaville Conference of 1944 and the creation of the French Union in 1946, leading to the Communauté of African states in 1958. As has been noted elsewhere, this gave rise to 'the stereotype of a more or less orderly transfer of power from Dakar to the Congo, formulated by stages and implemented without grave incident between 1956 and 1960'. ${ }^{15}$ The French counterpart to Britain's 'Whig' view of empire's end was neatly summarized in 1946 by Léon Blum, the prime minister, who spoke of 'our republican doctrine', in which 'colonial possession only reaches its final 
goal and is justified the day it ceases, that is, the day when a colonized people has been given the capacity to live and to govern itself'. ${ }^{16}$

That said, the idea of a French mission civilisatrice to match the civilizing mission of the pax Britannica was not always taken seriously by scholars of French imperialism. In 1960 Henri Brunschwig wrote that, while the 'humanitarian' angle was important for the British and their empire, in France it was post-1870 nationalism that provided the primary explanations for imperial expansion and legitimation. ${ }^{17}$ Early efforts to explore the concept more fully - particularly to examine its cultural dimensions - can be seen emerging, especially in the anglophone literature on the French empire, by the 1980s..$^{18}$ More recently a rich and varied literature has developed, much of it seeking to understand African perspectives. For example, Alice Conklin's 1997 book A mission to civilize: the republican idea of empire in France and West Africa offers a nuanced African perspective on the implementation of the Parisian policy debates explored in Raymond Betts' classic 1961 study, Assimilation and association in French colonial theory, 1890-1914. ${ }^{19}$ The role of religion has been a strong influence in the French historiography, helping to link together different understandings of how civilization was conceived and to stress the importance of the missionary element in realizing these visions. ${ }^{20}$ In the late nineteenth century and early in the twentieth, education was another vector for communicating the mission of the French state. ${ }^{21}$ In the interwar period we can see something of a shift in the civilizing mission away from a belief in the potential of assimilation towards a different type of cultural engagement. For example, Gary Wilder's The French imperial nation-state: negritude and colonial humanism between the two world wars picks up the problem of how race brushed up against humanist and rationalist justifications for the limiting of assimilation in the French colonial state. ${ }^{22}$

If the entire idée coloniale has now been subjected to severe historiographical criticism, it retains a certain salience in terms of postcolonial memory and the way in which the history of empire and decolonization is debated in France today. ${ }^{23}$ Much new debate centres on the teaching of empire and decolonization within schools. A 2005 law designed to 'show the nation's recognition of the national contribution of France's repatriate population' was the consequence of intense lobbying on the part of France's population of so-called pieds noirs, those citizens who trace their ancestry to the settler population in colonial Algeria. More commonly known as the law on the memory of colonialism, its fourth article called for school curricula to stress 'the positive role of the French presence overseas' and therefore of France's colonial history. It eventually 
provoked a fierce backlash and subsequently led the then president, Jacques Chirac, to rescind the law. ${ }^{24}$ Debates about imperial legacies have also crystallized around the idea of republicanism, and specifically the way that postcolonialism has clashed with ideas of neo-republicanism. ${ }^{25}$

In Britain, public debate about empire is often unhelpfully reduced to a 'balance sheet' approach. ${ }^{26} \mathrm{New}$ work on the violent repression of the Mau Mau Rebellion, as well as the high-profile court case of the Mau Mau plaintiffs against the British government, led to the discovery of a very significant cache of 'lost' or 'migrated' decolonization archives, increasing public awareness of some of the brutalities of decolonization..$^{27}$ Overall, however, the types of historians who are widely read by the public at large, as well as the media debates that this type of work encourages, tend to produce a 'for' or 'against' approach that dramatically reduces the complexity of colonialism. ${ }^{28}$ In these public debates, non-European agency has almost no role to play: only the deeds of colonizers feature, and most apparently still believe that, 'on balance', the British empire was a 'good thing' and its decolonization a largely benign or even benevolent process. ${ }^{29}$ The legacy of earlier historians, who believed so fully in Britain's benevolent imperial mission, still seems to resonate within public opinion. ${ }^{30}$ Even within the academy, questions of Eurocentrism, the failure to account for colonized agency, the lack of attention to colonial violence and the inability or unwillingness of some historians to take account of the prevalence of race within imperial discourse and governance remain some of the most contentious issues in the historiography of empire and decolonization.

The aforementioned ideas about decolonization as a relatively orderly transition, choreographed by metropolitan political elites, were being implicitly challenged by new strands of imperial historiography emerging in the 1960s. Ronald Robinson and Jack Gallagher's theory of imperial expansion, initiated in their famous journal article 'The imperialism of free trade' (1953) but developed most fully in their book Africa and the Victorians (1961), posited the politics of the 'periphery' as crucial to the decision-making undertaken by the 'official mind' in London (or Paris). By extension, then, decolonization could be interpreted as the consequence of the breakdown of collaborative relationship at the colonial periphery, which in turn shifted the balance of risk and reward for those seeking to prolong the imperial project. Despite the emergence of this 'peripheral theory', stressing the contingent and uncertain nature of imperial expansion and hence decline - and bringing a range of collaborators from the colonized periphery into the narrative - the implications for developing a richer sense of colonized agency were arguably stymied. 
Robinson and Gallagher still proffered an imperial framework that saw the ultimate decision-making role as lying within Europe's metropoles. The 'official mind' had to react to and take into account different 'peripheries', but it was still the main agent of historical change. ${ }^{31}$ Perhaps two generations of historians of Britain's decolonization have been heavily influenced by Robinson and Gallagher's concepts and analytical framework. 'Official mind', 'periphery' and 'collaboration' remained crucial categories of analysis. Beyond this, one of the definitive features of this style of scholarship is that the most utilized archives remain those of the former colonial powers, broadening through decolonization to encompass the foreign policy of the United States, the Cold War and international history. The emphasis is on the importance of high politics, strategic rationale and, above all, the decision-making power of politicians and bureaucrats at the imperial centre.

John Darwin, perhaps the pre-eminent historian of British imperialism and decolonization, is a vocal advocate for the ongoing importance of Robinson and Gallagher's work. ${ }^{32} \mathrm{He}$ also happens to be the target of some of the most intense and explosive historiographical criticisms in the field today. ${ }^{33}$ Ironically, Darwin is a staunch defender of the principle that the study of empire and decolonization should not be a morality tale of any kind, left or right, progressive or conservative - an approach that, again, takes inspiration from Robinson and Gallagher. Gallagher in particular offered 'an ironic, detached, and unsentimental view of the British Empire as a world system'. Empire was 'not a cause to defend or a grievance to denounce but a passing historical phenomenon', meaning that 'the history of empire as Gallagher and Robinson conceived it in the early 1950s was thus already a history for the postcolonial age'. ${ }^{34}$ It is this 'unsentimental' approach that provides the title for Bill Schwarz's review of Darwin's work, and seemingly also provides the main thrust of his critique. The problem, Darwin's opponents suggest, is that empire is not a 'passing historical phenomenon' but one that is still very much alive. The problem with Darwin's work, his critics propose - and the reason why he is unable to grasp the significance of empire's many afterlives - is that he is

hostile not only to the explanatory power now commonly accorded to matters of gender and race, but more generally to the conceptual significance attributed to the symbolic systems which give life in our daily existence; in the work of historical interpretation not only to gender and race, but to the social world, tout court. This marks not merely a professional spat, concerning this or that 
approach, a lowly question about the persuasiveness of a preferred methodology. The differences are serious and the stakes are high. In this Darwin is right: the controversy turns on what we can expect history to do. ${ }^{35}$

Darwin's contribution to the study of British imperial and decolonization is extraordinary in its range. Yet he is also very clear about what is and what is not important in the study of this history. Of primary explanatory value is the geo-strategic realm, and the decision-making of political elites in Europe's metropolitan centre. With regard to British decolonization, Darwin is well aware - indeed, he was a leading exponent of the view - that there was a 'fourth British empire' after 1945, in which modernizing forces sought to once again reconfigure the terms of imperial collaboration for a new age. Darwin too has discussed at length the 'late colonial state' and its historical significance. ${ }^{36} \mathrm{He}$ is well aware that there was more to the story of decolonization after 1945. But as a system - and therein lies the key to Darwin's historical register - the British empire was essentially broken and in terminal decline after the fall of Singapore in 1942. ${ }^{37}$

This is the aerial view of decolonization. Imperial history is surveyed from great heights, taking in the grand expanse of Halford Mackinder's 'World-Island' and Robinson and Gallagher's peripheries, but extending the analytical framework beyond a single core to take into account the broadest geopolitical shifts in modern world history, such as the rise of the United States' world power, fascism in Europe and Japan, China's imperial claims and so on. ${ }^{38}$ But in the plane, narrating the journey with Darwin himself, is an exclusive grouping of imperial grandees: the European, mostly but not exclusively British, political elites who form the centrepiece of Darwin's story. ${ }^{39}$ At one level, this seems eminently sensible: if the historical problem that Darwin has set himself revolves around questions of geopolitics and grand imperial strategy, these are the natural historical subjects to discuss it with. The reason why the debate about imperial and decolonization history gets so heated is the implication that this is not merely one way of looking at empire but, in reality, the most important. What Darwin's critics most object to is the absence of questions about race, violence and identity, and by implication the lack of attention to the historical experiences of those colonized subjects who literally disappear out of view when the empire is seen from such heights.

What the entangled historiography of decolonization suggests, unhappily for Darwin, is that, even when moral views of empire and decolonization are explicitly eschewed, the mere choice of subject 
matter and source material raises moral questions once again. Whether we look at interwar historians writing of empire as the steady unfolding of British constitutional liberalism, post-war modernizers and their historian sympathizers accentuating the developmental mission of decolonization, self-justifying politicians writing the history of decolonization as they act it out, popular debates about the legacies of decolonization, or historiographical disagreements concerning the proper focus of imperial and decolonization scholarship in the present, the old questions of Eurocentrism, morality and 'Who writes history?' have maintained their relevance. ${ }^{40}$

\section{From imperial centres to African agency: nationalism and its alternatives}

The critique of Eurocentrism is nothing new. It was, in essence, the first objection of anti-colonial nationalists. ${ }^{41}$ As national independence was mooted, and before a nation itself could be imagined, a national past had to be created. In terms of African history, nationalism, national or, more broadly, Africanist - historiographies seemed for a time to constitute a major rupture. ${ }^{42}$ Empire's end required new interpretations of the African past that would correct the tendency to view metropolitan political actors as the leading protagonists. Nationalism needed to be put centre stage. Nevertheless, the nation as a framework for writing history has proved to be problematic for a whole host of reasons, both political and analytical. For some, the seeds of postcolonial national identity were sown in rocky and unfertile ground. African nationalism was an elite-led phenomenon aimed at the capture of state power, with shallow roots in society. Empirically speaking, the myriad diversity of ethnic, linguistic and religious ties within often arbitrarily constructed borders essentially the creation of European colonial bargaining - rendered the postcolonial nation unstable and led to civil war, ethnic conflict, forced migration and genocide. At a more theoretical, normative level, the 'postcolonial' cultural turn of the 1980s and 1990s encouraged the idea of the nation as a discursive construct, often oppressive in its self-definition. There has since been a challenge to the anti-national orthodoxy, with historians reasserting the broad-based nature of some African nationalisms as well as the greater robustness of the African nation than is sometimes assumed. A different and newer historiographical turn has sought to re-examine and historicize the moment of political decolonization in the 1950s and 1960s, asking whether the nation state was the 
necessary and inevitable end of empire, and whether historians have sometimes wrongly attributed anti-colonial resistance to the category of 'nationalism'.

Post-war pioneers of an Africanist perspective such as Kenneth Dike and Jacob Ade Ajayi of University College Ibadan were seeking to place far greater emphasis on African agency and to develop African histories that stood apart from a unified 'imperial framework'. ${ }^{43}$ African (as opposed to merely imperial) history developed rapidly in the 1950s and 1960s when historians, in sync with the actual process of political decolonization itself, started to write alternative histories that did not simply portray the history of Africa as the history of the colonial powers. British repression in Kenya and Central Africa, as well as the underwhelming nature of Commonwealth membership, coupled with the brutal and ignominious collapse of the French empire in North Africa, stripped older explanations of credibility and created a potent opportunity to write histories of Africa freed from the clutches of an imperial narrative. Much of this new 'national' history aimed to examine the pre-colonial past, not taking European intervention as the beginning of history, and often searching for the pre-colonial roots of an ostensibly authentic identity and nationhood.

The new historiography was interested in African and local sources, including oral sources, which in many ways were the real innovation. ${ }^{44}$ In the 1950s scholars outside Africa - perhaps above all Roland Oliver also did much to shape the nascent discipline of African history. In 1948 the School of Oriental and African Studies (SOAS) appointed Oliver to a lectureship in the 'tribal history of Africa', the first of its kind. In collaboration with John Fage, then working in Ghana, Oliver also organized the first international conference on African history, in 1953, at which interdisciplinarity flourished, drawing on linguists, anthropology, archaeology, natural science and oral histories. Oliver and Fage produced the first textbook, A short history of Africa (1962), and the following year Oliver edited with Gervase Mathew the first volume of History of East Africa (1963). ${ }^{45}$ Immanuel Wallerstein, who published his Africa: the politics of independence in 1961, as well as Basil Davidson, Jean Suret-Canale and later Shula Marks and Catherine Coquery-Vidrovitch - among others sought to develop the historical study of African politics, nationalism and independence, looking from within colonial societies themselves. ${ }^{46}$ Much of the direction of travel here saw imperial history fragment into regional and national histories and a far greater emphasis on African initiatives and perspectives, with a palpable concern for politics and agency within colonized societies. ${ }^{47}$ 
Another early focus on African nationalism came from Henri Grimal's pioneering comparative study Decolonization: the British, French, Dutch and Belgian empires, 1919-1963. First published in French in 1965, and a landmark text in the study of decolonization, it offered a persuasive case for the central role of anti-colonial nationalism in the process of decolonization. Rather than sharing the strong Africanist focus of the early pioneers of Africa history, though, Grimal posited a different theory, one that has had an enduring influence in the historiography of decolonization. Anti-colonial nationalism was driven, Grimal proposed, by the process of colonialism itself and the dissemination of European ideas about nationhood and democracy, these being adopted by elites who then mobilized the masses in the face of increasing resistance to change on the part of the colonial powers.$^{48}$ Here the impact of European colonialism on African societies is maintained as an important focus of study, and the role of Europe returns to dominate the scene. In this sense, the historiography of empire and decolonization shared some core assumptions with those emanating from political science via modernization theory, essentially a focus on elite agency that sees that 'the student of political nationalism is concerned mainly with the attitudes, activities, and status of the nationalist-minded Western-educated elite'. ${ }^{49}$ Much writing on nationalism has adopted a similar 'dissemination' approach, seeing it as a fundamentally modern political ideology that has its roots either in Enlightenment ideas or in modern socio-economic change - or, indeed, a mixture of both. Either way, 'Third World' nationalism has often been seen as essentially 'derivative'. ${ }^{50}$ Grimal's perspective had important implications, however, for how theories of decolonization would reshape the study of imperial history. Whereas the new nationalist historiography pointed towards separation of nation - or at least region - from the prior imperial focus, Grimal strongly implied that imperial power and national resistance could not be so easily disentangled. A much more current historiography has stretched the chronological range of anti-colonial nationalism as a driver of decolonization to include the role of the First World War. The emphasis here is on interwar anti-colonialism and nationalism as fundamentally elite, intellectual projects - perhaps necessarily so - and hence the scope for including Africa beyond the activities of anti-colonial or pan-African intellectuals in London or Paris is somewhat limited..$^{51}$ Nonetheless, the methodological shift away from seeing nationalism as a separate development towards an emphasis on interaction, entanglement and networks of anti-colonialism is clear. ${ }^{52}$

Whether nationalism and the nation were elite-led constructs or notand the exact nature of any broader-based popular mobilization - remains 
a live debate in the historiography of decolonization and postcoloniality. Part of this discussion has focused around the 'second liberation' movements in Mozambique, Rhodesia, Guinea-Bissau and beyond, where armed guerrilla movements sought to cooperate with, some say co-opt, peasant movements into overthrowing the last vestiges of formal colonial power in sub-Saharan Africa, and 'envisaged a different kind of freedom, which would not merely substitute black faces for white ones, but transform the very nature of power itself'. ${ }^{53}$ In The wretched of the Earth (1961), Frantz Fanon talked about 'true' and 'false decolonization', and advocated a deeper, insurrectionary and essentially violent struggle against colonial power that would purge the body politic of the charade of flag independence, what he called the 'fancy dress parade and the blare of the trumpets' ${ }^{54}$ National movements that were actually in existence offered a 'bourgeois' form of decolonization that involved 'a few reforms at the top, a flag waving', while 'down there at the bottom' there remained 'an undivided mass, still living in the middle ages, still marking time. ${ }^{55}$

Earlier Africanist scholars, such as Basil Davidson, had often stressed peasant involvement in national movements. In terms of economic and military resources, Portugal was the weakest of all the European colonial powers in Africa, yet it resisted decolonization for the longest, fighting an anti-insurgency war in Mozambique into the 1970s. ${ }^{56}$ The Mozambican context thus gave rise to a large historiography looking at the nature of peasant mobilization, and hence at the form of anti-colonial nationalism that arose after and beyond the earlier wave of elite-led, primarily political movements. ${ }^{57}$ Rhodesia too provided a broad canvas for historical writing on later peasant mobilization in the anti-colonial struggle. ${ }^{58}$ Social mobilization and social conflict within national movements in the 1950s have now been re-examined through new intellectual perspectives. ${ }^{59}$ For example, while telling the story of colonial anti-insurgency in all its horrific brutality, scholars such as David Anderson have gone to great lengths to examine not just the suffering but acts of resistance and rebellion during the 'Mau Mau' campaigns of the 1950s..$^{60}$ Daniel Branch has taken the Mau Mau story further still. In his book Defeating Mau Mau, creating Kenya, the study of loyalist Kikuyu reveals the enormous complexity of Kenyan social movements and politicization, as well as the extent to which they sought to influence and manipulate each other and colonial authorities in ways that fundamentally challenge the category of 'nation' during decolonization. ${ }^{61}$

At the same time, an entirely different historiographical turn has sought to question the naturalness of nations and nationalism as vehicles for anti-colonial dissent. Here, rather than a search for new 
ways to look at nationalist mobilization, it is asked whether nations and nationalism were in fact the object of colonized subjects' political aspirations in the way that we often assume they must have been. In work by Frederick Cooper, a focus on alternatives to national frameworks and ways of thinking that did not see the nation state as inevitable prompts us to reconsider teleological assumptions about the nation in French and British Africa. As Cooper put it quite some time ago, 'The triumph of independence movements over colonial rule in Asia and Africa is another one of those metanarratives that needs to be rethought.' He has added that '[i]t is only hindsight that makes the territorial state seem like the wave of the future'. ${ }^{62}$ In contrast to the older, more African-centric literature on pan-Africanism, the focus here is on plans for federation involving French politicians in Paris, colonial officials in West Africa and a range of African national leaders and civil society groups: concrete political proposals to build upon pan-African ideals. ${ }^{63}$ As federated components of the empire came into being - and the 1956 loi cadre made power at the territorial level a reality - rather than treating metropole and colony separately the debates surrounding federal alternatives for a future French West Africa placed them firmly in interaction, being squarely debates about the future of France as well as Africa. ${ }^{64}$ Even if it quickly ran into the very difficult problem of how the citizens of these federated parts of the French Union could be equal with the citizens of metropolitan France, what is remarkable in Cooper's telling of this story is how far West African nationalists wanted to work, for a time, within the confines of a reformed, modernizing French empire. ${ }^{65}$ National resistance was a far more nuanced phenomenon than we may have been led to believe.

It has been suggested that, while the visions of French West Africa's political elites 'did not centre...on the compartmentalised spatial order that came into being with independence', elsewhere in Africa 'nationalist leaders and elites accepted the spatial order colonialism had imposed'. ${ }^{66}$ This reflects the current bias in this historiography towards the decolonization of francophone Africa. Nevertheless, what makes the experiments with federations in West Africa potentially all the more interesting for the study of African decolonization is that this 'federal moment' was also witnessed in British-controlled territories in central, southern and East Africa. ${ }^{67}$ Having carved the Central African Federation (CAF) out of Northern and Southern Rhodesia plus Nyasaland in 1953, some British colonial officials briefly flirted with the idea of formally federating East Africa in the early 1950s. This provoked much anxiety in Uganda, where Buganda sensitivities about their status within the Protectorate 
combined with wider concerns about an East African federation, which for them meant domination by the white settlers of Kenya, a spectre made all the more threatening by the now-existing CAF. In Uganda, attitudes towards East African federation remained less enthusiastic than in Kenya and Tanganyika. In all three countries, however, opinion polling in the region suggests an apparent groundswell of public support for federation. Nyerere's offer of June 1960 to delay Tanganyika's independence so that, together with Kenya and Uganda, a federation could be achieved - combined with the Nairobi Declaration of June 1953, in which Obote, Kenyatta and Nyerere ostensibly committed their nations to federation - suggests that the 'wind of change' may have been blowing in different directions; not simply towards national self-determination as the achievement of nation-statehood. Yet, as Samuel Moyn has pointed out in a penetrating review essay, if that is so, then why did the nation state ultimately achieve its universal triumph? ${ }^{68}$

Decolonizing states in Africa and beyond were faced with the challenge of multiple and competing sovereignties. In Uganda, the Buganda contested the legitimacy of the political unit created by the British Protectorate. In Kenya, loyalty among denizens of the Kenyan coast to the Sultan of Zanzibar clashed with efforts to create a unitary Kenyan nation, as did the Somali orientation of the shifta in Kenya's north. ${ }^{69}$ As Emma Hunter has argued, Tanganyika's United Nations trust territory status created ambiguities between British sovereignty and international jurisdiction. ${ }^{70}$ Across the continent, concrete proposals for statehood were imbricated in wider debates about African identity and fear of 'balkanization' - a word used explicitly and frequently in both West and East Africa. ${ }^{71}$ Although the federal tendency worked to accommodate and stabilize regional, ethnic and linguistic divisions belying national unity, arguably it was not in spite of but because of these divisions that the model of sovereign, unitary nation-statehood won out.

In Africa, as elsewhere in the decolonizing world, even while recognizing the artifice of the nation state, the 'Westphalian' model of statehood offered a 'principle of unity' that drew together 'the multiplicity of powers within the political realm'. ${ }^{72}$ This arguably served to concretize a direct link between anti-colonialism and the achievement of nation-statehood, with nationalism offering a catch-all solution within which all grievances against the colonial state could be mobilized to achieve independence. This reminds us, then, of the importance of the international dimensions determining the shape of sovereignty and the move to nation-statehood in the 1950s and 1960s, which Ryan Irwin and others have pointed to in a renewed historiographical focus on Africa's 
decolonization in international perspective. ${ }^{73}$ National frameworks could mask internal divisions in Africa, offering nationalist elites a way to rapidly integrate themselves into a liberal international order that also offered benefits for Western powers such as Britain, France and the United States in the context of the Cold War.

In some senses this appears to make decolonization a relatively contained phenomenon, rapid in its conclusion. In 1955 UN membership constituted seventy-six sovereign nation states, but only seven of these were formerly colonized states. By 1965, though, UN membership had risen to 117 countries, the vast majority of these new nation states having been created through decolonization, which had accelerated rapidly after the independence of Ghana and Malaya in 1957. ${ }^{74}$ In line with the debates about federation in the 1950s, however, this international perspective also emphasizes African agency, telling a story of how African (and Asian) states manipulated and shaped debates about nationhood in an international context from the late 1950s into the 1960s. Even if Erez Manela's 'Wilsonian moment'75 may not have been a moment for Africa, the post-war national moment saw sub-Saharan Africans vigorously assert ideas about race, pan-Africanism, statehood, equality and modernization in a new world in which the 'subjection of peoples to alien subjugation' ran against the UN Charter and could be deemed the very cause of international and interracial conflict. ${ }^{76}$

Advocates of new national histories, such as Kenneth Dike, were actively involved in the process of decolonization through asserting a national story separate from that of Europe. Even when European imperialism was brought back into the picture, there was widespread agreement that anti-colonial nationalism was a key part of the decolonization picture, whether because of the dissemination of ideas from Europe, socioeconomic processes of change, elite mobilization or more complicated patterns of popular mobilization. And the latest move to question the naturalness and inevitability of the nation state has already been called into question: an important new book by Michael Goebel addresses the question of alternatives to the nation, chronologically reframing nationalism in the interwar as well as post-war periods once again, and positing the 'various discourses envisaging a postcolonial world as competing or mutually complementary strands of nationalism, not as federalisms or regionalisms versus nationalism. ${ }^{77}$ Goebel's assertion is that, even if 'the nations that interwar anti-imperialist's imagined did not always coincide with the postcolonial states emerging in the 20 years after 1945', this alone is 'not a good enough reason not to treat these discourses as nationalist'. ${ }^{78}$ 
Whether nationalism must necessarily be such a large-tent phenomenon, so that anti-colonialism once again finds its proper resting place in the post-war nation state, remains a moot point. It is likely that the historiographical debate over the place of nations and nationalism in Africa's decolonization will continue for some time. Even now, the ongoing debate about nationalism and the nation state during post-war decolonization is yet another reminder that the field continues to surprise us with its vibrancy, with fresh questions and perspectives being churned up from the seabed of empires' ends as each new wave of critical thought crashes in.

\section{The colonial and postcolonial state}

Perhaps nowhere is this truer than in the area of the colonial state, in its late manifestations and its postcolonial legacies. The penetration of the colonial state into colonized societies - whether through taxation, the policing of labour unrest, surveillance, anti-insurgency or ostensibly more benign 'development' schemes - was itself a driving force of nationalist consciousness. But the historiographical focus on the state-distinct from, though historically and analytically connected to, the rise of anti-colonial nationalism - has brought into view a range of other important questions. The early Fanonist critique of an elite-led 'false decolonization', in which very little changed - and, crucially, core elements of the state and economy carried over in the transition from colonial to postcolonial periods - has evolved through various forms of analysis and criticism of the postcolonial state from within Africa itself. A different historiography, more imperial in its focus, has sought to bring the late colonial state into analytical perspective as something that marked both colonizer and colonized. Fanon's position would feed into postcolonialism, a mode of critical enquiry citing knowledge itself as a form of colonial power and control. Initially theoretical, concentrating on the sometimes overly abstract idea of discourse, one can detect the influence of this mode of enquiry in the new historiography of decolonization that advances a more empirical social history of ideas, seeking to elucidate the ways in which colonial knowledge was reified in state practice and social organizations that bridged the late colonial and colonial periods, for example through the field of 'development'. This has meant looking not only at the composition and support base for national movements but also at the nature of the state inherited from the colonial power. 
Economic explanations for imperial expansion were prominent throughout the twentieth century, and as early as 1957 an economic explanation for decolonization was being offered by Paul Baran in his seminal The political economy of growth. Baran argued that, whereas empires had previously been advantageous to the fortunes of international capitalism, after 1945, and increasingly into the 1950s, the politics of imperialism and the interests of international capitalism were at loggerheads. Where multinational businesses felt that they were well placed to work with new nationalist leaders, the intransigence of colonial rulers was likely to create anti-foreigner and anti-capitalist extremism that would play into the hands of the communist world. ${ }^{79}$ For this reason, European imperial powers were under huge pressure to facilitate a swift political decolonization, enabling the capitalists to carry on with business as usual, under new arrangements. The emergence of ideas based around 'dependency' or the neo-colonialism of markets and international organizations drew heavily on neo-Marxism and on the politics of the Cold War context out of which they emerged. Andre Gunder Frank's highly influential Capitalism and underdevelopment in Latin America (1967) provided a great deal of the theoretical apparatus for work on other parts of the Third World.

A classic example for the African context is Walter Rodney's 1973 How Europe underdeveloped Africa, a longue durée perspective on colonial exploitation leading right through to the postcolonial persistence of dependency. ${ }^{80}$ From a different political perspective, Ronald Robinson and Roger Louis' important article on 'The imperialism of decolonization' stressed the role of the United States, particularly through collaborations with Great Britain, in pursuing informal empire after decolonization as a means of fighting the Cold War. ${ }^{81}$ Broad ideas of dependency and 'neocolonialism' continued to resonate throughout the developing world, particularly in Africa and Latin America, through the 1980s and well into the 1990s. Opposition to the 'Washington Consensus' on neoliberal state reform, thought to be imposed on Africa via the 'structural adjustment' plans of the International Monetary Fund and World Bank, became a rallying cry. In terms of decolonization scholarship, one of the few historians to engage in a careful rebuttal of the arguments advanced by the dependency theorists was David Fieldhouse, who argued that, in fact, the emphasis on commodity exports in sub-Saharan Africa after independence was, first, 'not necessarily fatal to economic development' and, moreover, explanations for underdevelopment should place far more emphasis 'on the policies adopted by the new rulers of Africa, on the way these were carried out and, above all, on the political systems evolved 
to support the ruling elites'. ${ }^{82}$ Within the field of history, the economics of decolonization as it affected Africa remains an area of enquiry that is arguably in need of expansion, though the literature on the metropolitan economic dimensions of decolonization has been more thoroughly explored. ${ }^{83} \mathrm{~A}$ current contribution to the historiography has in fact subjected the whole idea of neo-colonialism to scrutiny, suggesting that, in East Africa at least, the claim that colonial structures of power remained in place after decolonization because former colonial powers had willed it to be so is too simplistic. ${ }^{84}$

To bring the dispute about neo-colonialism full circle, the critique of the postcolonial state has actually extended far beyond the realm of the economy to include, in some cases, calls for the establishment of a 'new trusteeship' to rescue the supposedly 'failed' African postcolonial state from itself. This debate probably reached its most heated point in the mid-1990s, in the context of strong disagreement about the bearing of structural adjustment in Africa. Perhaps the most controversial figure at that time was Ali Mazrui, the Kenyan-born author of many works in history and political science, who by the 1990s held a professorship in the humanities at Binghamton University, New York. Mazrui's interventions in the press calling for the 'benign colonization' of Africa by African hegemons (a Pax Africana) drew predictable outrage from many quarters, but were in fact provocative expressions of a wider anxiety about the viability of the African state. ${ }^{85}$ Attention has also been focused on the African state from the fields of political science and international relations, less out of a concern for African welfare than from a fear of the African 'failed state' being a seedbed of international terrorism. An early proponent of this thesis was Robert Jackson, who termed the African postcolonial state a 'quasi-state', which could survive only because the 'precipitous decolonization' in Africa had been facilitated by an international state system whose legal principles worked against the maintenance of domestic jurisdiction on the part of colonial powers, and hence encouraged a rapid decolonization process. ${ }^{86}$ The upshot, Jackson argued, was that ex-colonial states had been 'internationally enfranchised' with 'juridical statehood', but many of them have not 'been authorised and empowered domestically and consequently lack the institutional features of sovereign states, as also defined by classical international law'. ${ }^{87}$

While Jackson and others point the finger of blame towards the legacy of decolonization in the realm of international law, others have argued for a process of 'second independence', which takes into consideration the international realm but seeks to combine this with historical particularity and specificity in its search for solutions to the problems of 
the African state. ${ }^{88}$ According to Eghosa Osaghae, 'second independence' is a popular movement from below that calls for decentralized, sometimes federal forms of government that can meet the development needs of African people. ${ }^{89}$ As Paul Ekeh has put it, second independence - or what he calls 'second liberation' - is not about the violent guerrilla wars of the 1970s but 'about gaining democratic rights from post-independence domestic tyrants', which must be done by developing 'a sharp focus on the behavior of the state, especially in its uses of the public domain and its interaction with the institutions of civil society'..$^{90}$ For Africa, then, the debate about the postcolonial state hinges not simply on the colonial legacy but, equally, on the nature of postcolonial political participation, pointing us yet again to the interconnectedness of past and present when seeking to reimagine new future trajectories of political and economic development.

Despite the ongoing conceptual and political resonance of 'dependency', 'neo-colonialism', 'failed' or 'quasi' states, Osaghae's point about popular participation and interaction with the state reminds us once more of the importance of placing agency - or, put simply, just 'people' centre stage; this is something that, arguably, historians are more prone to doing than their political science and international relations counterparts. ${ }^{91}$ Mahmood Mamdani's Citizen and subject: contemporary Africa and the legacy of late colonialism (1996), for example, utilizes the concept of the 'bifurcated' colonial state, split between the direct rule of administrative colonial cities and towns and the decentralized, indirect rule of the rural areas. The legacy for Africa has been rural power structures that were not broken but, rather, further 'Africanized' and that maintained their coercive capabilities vis-à-vis rural labour. As such, questions of civil society, political leadership and collective action have become central to the analysis. ${ }^{92}$ Frederick Cooper's influential Decolonization and African society, published in the same year, shows how African workers and trade unionists interacted with and hence shaped French and British schemes for colonial modernization. ${ }^{93}$ Cooper posits the idea of colonial states as 'gatekeeper' states, which had 'weak instruments for entering into the social and cultural realm over which they presided, but...stood astride the intersection of the colonial territory and the outside world' ${ }^{94}$

The implications of this were that Africans under colonial rule sought ways to circumvent the colonial state's control of access to the world beyond its borders. At the same time, anti-colonial nationalist elites were aware that the power they were inheriting was limited, and indeed the reality was that 'the postcolonial gatekeeper state, lacking the external coercive capacity of its predecessor, was a vulnerable state, 
not a strong one'. As a consequence, ruling elites after decolonization have tended to utilize methods of patronage and coercion in order to maintain control of 'the gate'. In a political version of the economic 'resource curse', in which efforts to seize control of single or very limited economic resources such as mineral wealth or oil tend to lead to corruption and dictatorship, the gatekeeper state is vulnerable for the simple reason that anyone who seizes control of it must stay in power. No one can afford to lose control, because there are no avenues for wealth or other loci for power other than controlling the gate. Cooper suggests that the gatekeeper state concept helps us to look at the postwar era in its entirety, enabling us 'to explain the succession of crises that colonial and postcolonial states faced, without getting into a sterile debate over whether a colonial "legacy" or the incompetence of African governments is to blame'. ${ }^{95}$ The overarching point is that contextualized political action, fundamentally a problem of structure and agency, has shaped Africa after decolonization in ways that require more subtle forms of analysis than the 'culpability quest' that has sometimes seemed to predominate in the older literature. Social, economic, political and cultural structures in postcolonial Africa are neither imported nor indigenous, but have developed through the interaction of the said structures with African agents at all social levels, and in particular contexts.

The idea of the African state as a bridge between colonies and 'the outside world' takes us back to a historiography of the colonial and postcolonial state in which there is an alternative line of investigation: recentring the realm of imperial politics towards an emphasis on the impact of the state for both the colonizer and the colonized. Here, the debate does not ignore the role of the colonial state in Africa; far from it. Instead, it seeks to keep both colony and metropole in the same framework of analysis, and, in so doing, also points towards the ways in which the late colonial state in Africa had commonalities with colonial states elsewhere. As discussed above, historians have argued that the whole project of late colonial 'modernization' gave impetus to processes of social change that in turn increased demands for decolonization. At the same time, what Anthony Low and John Lonsdale famously termed the 'second colonial occupation' also gave rise to a new impetus for colonial economic development, science, technology and modernization schemes that would have ramifications for the colonial powers themselves, and indeed for newly emerging international institutions. ${ }^{96}$ The concept of the late colonial state therefore points not just to the politics of decolonization in the newly emerging nation state itself but also to the imaginings of continued 
colonial rule, in modified form, on the part of the politicians and policymakers in imperial centres after 1945. ${ }^{97}$

In Martin Shipway's comparative study of decolonization, the late colonial state - particularly in Africa - plays a central part in revealing connections between the late colonial and decolonizing experiences of Britain and France. Thinking about the view from London or Paris, Shipway argues that, even before the material and ideological shifts effected by the Second World War, colonial powers were having to work far harder to maintain the imperial equilibrium as they 'confronted the deeper continuities of imperial instability, or of resistance or challenge to colonial rule, or contemplated the sort of policy reforms which were to become commonplace after 1945 '. What is brought sharply into relief is the fact that any ideological division between 'liberals' and 'conservatives' in Europe after 1945 was simply false: both groups were intent on preserving empire 'in some shape or form' in order to at least 'manage the process of colonial change over the medium to long term. ${ }^{98}$ The added advantage of Shipway's emphasis on the late colonial state is that it provides another framework for thinking about agency from the perspectives of both the colonizer and the colonized. The evolving nature of the late colonial state's adaptation, contestation and rejection explicitly involved the colonized not simply as an undivided nationalist 'mass', represented by a handful of elite leaders, but a delineated range of actors and groups interacting with colonial powers, and each other, as the postcolonial state entered into view. ${ }^{99}$ On the other side of the spectrum, the project of late colonialism, varied as it was, required ongoing commitment from metropolitan actors that raises yet again the importance of decolonization and often specifically African decolonization - in which British and French academics, intellectuals, policy-makers and administrators continued to see themselves as having a major role to play. ${ }^{100}$

One area of interest that draws out the ways in which the colonial state had local, as well as comparative or even transnational, dimensions lies in the study of colonial violence and coercion. The previously discussed historiography on Mau Mau has been an important driver in this area, as has the vast literature on French colonial violence, particularly in Algeria. ${ }^{101}$ Yet colonial violence cannot be reduced to large-scale massacres or brutal acts of violence that captured international media attention. In fact, the everyday, banal nature of colonial violence is crucial to our understanding of colonialism and decolonization. The colonial state's capacity to police and control colonial populations at the local level was, as is now widely understood, heavily dependent on indigenous collaborators. ${ }^{102}$ This is turn shaped the politics of intra- and inter-ethnic 
violence that has been a marked legacy in the postcolonial era. Violence and coercion arose too in the context of the political economy that was fundamental to the daily workings of colonialism - indeed, that was arguably central to its rationale. For example, historians have explored the ambivalent effects of colonial taxation as a means of coercing natives into the labour force or to produce certain kinds of cash crops. ${ }^{103}$ As Ann Laura Stoler has made us aware, albeit from a South-East Asian angle, the repression of anti-colonial resistance often involved a blurring of the lines between political agitation, economic grievance and criminality, which brought labour relations very much to the forefront of the minds of colonial administrators and their police powers. ${ }^{104}$ Martin Thomas' recent seminal work on Violence and colonial order places great emphasis on the centrality of political economy to our understanding of how the colonial state reacted to and evolved its approaches to coercion, with the control and policing of labour unrest being central to this development. ${ }^{105}$ Thomas' work also makes a major contribution to a decolonization historiography that is comparative and transnational in its perspective. ${ }^{106}$ While going to great lengths to detail spatial and temporal specificity, Thomas borrows from more sociological and theoretical approaches to develop a cross-imperial comparison taking in British, French and Belgian policing regimes, revealing some of the 'distinctively colonial types of repression as written in the very formation of colonial states'. ${ }^{107}$

New work is now being done in an area of decolonization historiography that explores not just empire - or colony-specific case studies - but also the broader networks of knowledge and practice that offer another linkage between the late colonial, decolonization and postcolonial periods. Here we also see, either implicitly or explicitly, the legacies of postcolonialism's theoretical innovations at play, with an emphasis on the longevity of colonial 'power-knowledge' and the need to move beyond formal, flag independence to look at deeper processes of decolonizing in the realm of culture and intellect as well as the postcolonial state. ${ }^{108}$ At the level of Foucauldian discourse, the postcolonial turn has had a major sway in studies of the postcolonial state in Africa and the limits of decolonization as manifested in the legacies of international influence and control. ${ }^{109}$ James Ferguson's The anti-politics machine (1990) was a major interdisciplinary contribution, focused on the 'depoliticizing' effects of 'development' and 'modernization' discourses in Lesotho that substituted technocratic perspectives for the views of those actually being governed. ${ }^{110}$ In general terms, however, particularly when they operated most clearly as a form of theoretical, moral or literary critique of broad, abstract categories such as 'the imperial', 'Europe' or 'the West', 
the openings offered by the postcolonial turn have also arguably obscured and closed down some areas of investigation. As Stephen Howe put it in a typically trenchant critique, some of what emerged from postcolonialism, particularly in the 1990s, appeared to abandon the idea that colonialism was at its core 'a juridical relationship between the state and territory; one in which the colonizing state took complete power over the government of the territory which it had annexed. ${ }^{111}$ Others, such as Achille Mbembe, have articulated similar concerns about the abandonment of the political in favour of the discursive. ${ }^{112}$ As Andrew Zimmermann has put it, historians can sometimes be too keen to resist Eurocentrism by an exploration of the European racist discourses that inform it, rather than the non-European histories that Eurocentrism obscures. ${ }^{113}$

Much of the best literature now operates as a form of socialintellectual history, what might be termed a social history of ideas, in which the abstract notion of discourse is supplemented by a more concrete investigation of how forms of knowledge were developed and deployed in particular institutional or social contexts. This can be seen in the important work on both anglophone and francophone Africa of Christophe Bonneuil, which homes in on the crucial role of scientific thought in the processes of development that marked the late colonial and postcolonial state and 'played a central role in the making of this development regime and its maintenance after decolonization.. ${ }^{114}$ In recent years a very large literature focusing on decolonization and the legacies of empire has centred on these problems of development and scientific knowledge, again demonstrating the possibilities of studying the decolonization and postcolonial condition of Africa by drawing on the insights of postcolonialism and using a wider lens that seeks to incorporate international and transnational perspectives as well as the older metropole-colony perspective. ${ }^{115}$ The focus on science and development in Africa's decolonization has provided strong empirical grounds for such investigations. A new interest in the history of humanitarianism seeks to understand the shifting relationship of non-governmental humanitarian organizations in relation to colonial power and authority as well as the challenges of operating in newly sovereign postcolonial Africa. ${ }^{116}$

What is clear, then, is that, from many different angles, there is an enduring and in fact renewed interest in and emphasis on the nature of the state during and after African decolonization. Whereas many African historians have long asserted the importance of the state, and indeed the related concept of 'political economy', this is a move that constitutes something of a departure in terms of the 'New Imperial History', which has often tended to focus on questions of discourse and identity. 
Richard Price, a social historian of Britain who, along with many others of a similar generation and early training, took the 'imperial turn' in the 1990s, has pointed to the renewed vigour in the study of the history of the British empire and its decolonization, particularly in the wake of the 'linguistic turn' and its emphasis on culture; but he has also asked: 'Is it possible to write a history of Empire without considering political economy or without some notion of the state as a historical actor in the imperial process?'117

\section{Integration and new orientations}

There are now very many ways of thinking and writing about the history of African decolonization that point to a welcome openness and pluralism in the current historiographical climate, as well as new possibilities for 'unity' in terms of former imperial, postcolonial, regional and national historiographies engaging fruitfully with each other. The early incarnation of postcolonialism as a form of critique grounded predominantly in literary studies and high, abstract theory has largely passed. Amidst this ecumenicalism, it is clear that in the wake of the postcolonial turn there is renewed interest in questions of politics and economics, which engages with the concept of discourse but seeks a strong empirical basis upon which to investigate and identify the complex, multi-layered ways in which decolonization reshaped the lives of Africans. This means, for example, rethinking the terms under which the nation or national political unit came into being. Understanding these processes of imagining, adopting, adapting and contesting requires us to link social and cultural history to the business of the state and international politics. In fact, the colonial and postcolonial state offers an integrating analytical framework for a whole range of historical problems from the practice of politics and African agency, nationalism and its alternatives: control and coercion, territory and sovereignty, networks of knowledge and the enduring question of the moral legacies of empire. ${ }^{118}$

What is also clear is that decolonization is not simply about the end of empire as an event - even a prolonged one - that implies a more or less discrete historical object of study. In this sense, decolonization should not be seen as a point at which empire ceased to be important in the world, nor as the moment when nations recovered their autonomy from the shell of imperial domination. This is also a critique of triumphalist narratives, whether on the part of self-congratulatory former colonial powers or anti-colonial nationalist elites. As colonized 
and colonizer are brought back into the same analytical framework, those binaries are broken down. Decolonization ceases to be a teleological triumph, and is instead a messy, contingent, uneven and unresolved process of change in which our understanding of what happened in the past enables and constrains our sense of possible futures. Decolonization might thus be seen as a point at which certain aspects of a world shaped by empire fell away, while others continued and some morphed into new forms of power, exchange, integration and fragmentation. In adopting an anti-teleological approach such as this, we offer ourselves the intellectual space to examine the unrealized potentialities of decolonization beyond the 'empire-nation dichotomy' and to imagine the possibility of alternative forms of sovereignty - and hence of Africa's political future. ${ }^{119}$ 


\title{
2
}

\section{'The winds of change are blowing economically': the Labour Party and British overseas development, 1940s-1960s}

\author{
Charlotte Lydia Riley
}

Imperial entanglements drew not only on painful legacies of exploitation but also on laboured traditions of debating development. Towards the end of empire, continued imperial engagement was often predicated on the supposed bounties from colonial development programmes depending on the audience, for either the metropole or the colonial people; after decolonization, postcolonial engagement was framed by the ongoing legacy of expired colonial schemes. This chapter examines the Labour Party's approach to overseas aid and development at two key moments in the context of British decolonization, the 1940s and the 1960s. From the 1920s British colonial policy had become increasingly articulated through a language of 'progress' and 'development'. This was enshrined in British law with the Colonial Development Act (1929) and the Colonial Development and Welfare Acts (first passed in 1940). During and after decolonization, this approach was continued in Britain's relationships with the newly independent nations of the 'developing world', and the legacies of colonial policies, rhetoric and ideology can be traced in the Ministry of Overseas Development (established in 1964) and the Department for International Development (1997). After the empire ended, ideas about 'civilizing missions' and imperial burdens did not melt away; instead, they were absorbed into a wider dialogue about Britain's (and Britons') place in the world.

The contemporary construction of a British identity within the international community as a giver of aid, within a network of international and transnational humanitarian organizations, has been 
constructed within the ongoing legacy of British colonialism and decolonization. In turn, this international identity has shaped, and been shaped by, domestic British politics, with the rhetoric of aid and development having been enthusiastically embraced by the British left. This chapter explores the connections, ruptures and continuities between British development policies in Africa at the end of empire and in the newly postcolonial world. It spans the imagining of colonial futures, and revisits those late colonial dreams in post-imperial daylight. In doing so, it contributes to a wider discussion of how the British dealt with the transition from colonial development to postcolonial overseas aid - and from empire to the end of empire.

The chapter begins by exploring a specific moment in the history of colonial development, the period immediately following the end of the Second World War. Despite its position among the victorious Allied powers, this period saw Britain trying to come to terms with itself as a world power dwarfed by two superpowers, an economic powerhouse crippled by debts and supported by foreign governments, and an empire losing its territories. This decline of British power and prestige must not be exaggerated, however. The 1950s and 1960s saw economic growth and an increase in living standards for much of the population. Britain maintained an international diplomatic role, holding crucial positions in the United Nations and North Atlantic Treaty Organization (NATO), and, although the later twentieth century would see widespread decolonization, the seeds of that independence struggle were only just being sown in many territories in the British empire.

The history of British imperial rule in the post-war period has often focused on the struggles for independence and the gradual dismantling of the British empire in Asia, Africa, the Caribbean and the Middle East. The mobilization of the empire in the Second World War, arguably the point at which the empire was at its most cohesive, has itself been identified as responsible for the wave of decolonization seen in the post-war period. ${ }^{1}$ There was in fact, however, a concerted reassertion of metropolitan control over the empire in the immediate post-war period, often described, in Anthony Low and John Lonsdale's words, as a 'second colonial occupation'; it was perhaps instead this new 'intrusive and often haphazard imperialism of the era of reconstruction' that provided the 'fundamental watershed' for European decolonization. ${ }^{2}$ The period is therefore critical for the wider understanding of British overseas aid and development policies in the twentieth and twenty-first centuries; in many ways, the policies pursued in the immediate post-war period set the tone for the relationship between Britain and its (ex-)colonies in the 
following decade. Efforts to prolong empire in the period after the Second World War through developmental colonialism fostered lingering entanglements between Britain and Africa, not least within the Labour Party. This suggests important connections between this period and the Labour Party's approach to aid and development in the 1960s, when most of the British empire had been dissolved.

The Labour Party's engagement with the history of development can be used to explore not only the relationship between Britain and the developing world but also how a specific group within the (former) metropole perceived this relationship, and how this perception shaped Britain's aid and development policies. ${ }^{3}$ Focusing on the Labour Party enables the exploration of aid and development as a topic of political thought and an area of political policy that is sold in the domestic sphere but that operates in foreign climes; in this way, aid and development can be used as a prism through which to understand how Labour viewed itself and its key principles both at home and overseas. The history of aid and development policies can be used to elucidate the long roots of decolonization in European imperial history, as well as the practical, rhetorical, ideological and (above all) human continuities that blur the transition between living and dying empires. Throughout the twentieth century, development and aid policy occupied a specific space in political discourse, incorporating a number of different themes, including charity and philanthropy, progress and change, and the ongoing legacies of colonial rule. In this way, development (and, in turn, the developing world) can act both as a canvas, onto which ideas about the world could be projected, and a lens, through which attitudes can be examined and interrogated.

The issue of overseas aid and its relationship to colonial policy has been tentatively addressed in a number of edited volumes over the last decade; these have mostly focused on the connections between colonial development and other forms of humanitarian action, or the legacies of colonial development programmes in contemporary policy in ex-colonial states, and have tended to emphasize the role of non-governmental organizations (NGOs). ${ }^{4}$ Similarly, Michael Barnett traces the history of overseas intervention from the imperial age to the end of the Cold War, yet, by framing this history within a narrative of progression, he fails to emphasize the continuities between the periods under question. ${ }^{5}$ By contrast, Michael Jennings, in his work on development in Tanzania, highlights the continuities in personnel and approach between colonial and postcolonial development; this issue has also been addressed by Joseph Morgan Hodge, in his work on agrarian policy. ${ }^{6}$ Again, however, these texts focus mainly on NGOs and charities rather than official policy, despite the long 
history of intervention by former colonial metropoles in the developing world, and despite the fact that this intervention is irrevocably shaped by the colonial legacies of the relationship between nation states in Europe and the global South. As Hodge has argued, the European powers used the rhetoric of development to make claims that discontent among colonial populations was rooted not in political, racial and economic oppression but in 'substandard living standards and inadequate government services'. In this way, the British could focus on 'large-scale government planning and state-directed welfare schemes', to dismiss the inequalities inherent within imperialism as mere 'technical problems' that were easily remediable without the radical solution of decolonization. ${ }^{7}$ The contingent factor in this metropolitan analysis did not stem, therefore, from the inherent asymmetries of empire; rather, it was a more flexible relationship predicated on commitments to development itself inherent in the civilizing mission. This can also be extended into the postcolonial period, when the rhetoric around development and humanitarian aid served to maintain this dynamic, while eliding the ways in which underdevelopment was rooted in recent colonial history. By charting these debates on aid and the economy, we can gain some insight into the historical constellations that guided Labour policy-makers, and the winds of change that buffeted them. Enduring themes thereby emerge that allow for a sustained analysis of agency, intent and the entanglements that beset the Labour Party and British overseas development.

\section{British overseas development: a chronology}

The British empire had traditionally been managed through the idea that colonialism should pay for itself; the 'civilizing mission' professed by nineteenth- (and twentieth-)century colonialists was tolerated only because imperialism was itself profitable for the metropole. This profit could either be financial and tangible - oil from Nigeria, cotton from India, diamonds from South Africa, as well as the large revenues that Britain drew from imperial-preference trade and the sterling area - or more abstract, such as the increased power and prestige that Britain gained through its imperial position. But profit and power were at the heart of empire. ${ }^{8}$ Colonialism was based on 'conquest, exploitation and subjugation', impulses that might have been justified through Enlightenment claims to universal principles but that functioned only to deny these principles to the colonial subjects against whom they were employed. ${ }^{9}$ 
The 1929 Colonial Development Act can be read as a continuation of nineteenth-century imperialist exploitation, framed within a new discourse of 'development' that had become more popular in the interwar period; for example, the provision of 'technical assistance' to the colonies had been tentatively embraced in the 1920s, with improved staffing of medical, agricultural and scientific departments around the empire. ${ }^{10}$ The act had two purposes: to promote colonial development, and to benefit the British economy, which was suffering from high unemployment. As a report by the Overseas Development Institute (ODI) in 1964 describes, '[T]he second [motive] has been stressed in later comments'; although many people involved were doubtless motivated by progress in the colonies, it was as a panacea for domestic unemployment that the act was packaged and sold. ${ }^{11}$ In this it was a categorical failure: shortly after the act was passed, Wall Street crashed and the Great Depression took hold of the world economy, unemployment in Britain rocketed and the funds available for colonial development were severely curtailed. By January 1931 the act had provided work for around 13,000 men, out of 2.7 million registered unemployed. ${ }^{12}$

Nevertheless, enthusiasm for colonial development was not destroyed by the failures of the 1929 act. The first Colonial Development and Welfare (CDW) Act was passed in 1940, largely through the efforts of Malcolm MacDonald, the pioneering 'National Labour' Secretary of State for the colonies, appointed in 1938. The CDW Act moved away from the simple imperialist mercantilism of the 1929 Colonial Development Act to also provide for the development of welfare resources; MacDonald believed that, if Britain did not provide 'proper social services' for the colonies, then it would inevitably and deservedly lose them. ${ }^{13}$ The CDW Act was therefore 'authorised to make schemes for any purpose likely to promote the development of the resources of any Colony or the welfare of its people'. ${ }^{14}$ The British government could spend up to $£ 500,000$ a year on schemes either 'promoting research or inquiry'; another $£ 5$ million was budgeted every year until 1951 for all other projects. ${ }^{15}$ The CDW Act was administered directly by the Secretary of State for the colonies, rather than the Treasury, which had overseen the 1929 Colonial Development Act. The CDW Act of 1940 was hampered by the fact that 'the purposes of war' had to have 'the first call on the resources of the country, whether in men, material or money'. ${ }^{16}$ By the end of March 1946, however, 595 development and welfare schemes and 105 research schemes had been initiated, at a total cost of $£ 28,841,000 .{ }^{17}$

Even before the end of the war, Parliament had voted to increase the provision for colonial development and welfare in order that colonies 
should be enabled to pursue an active policy of development when peace returned'. The 1945 CDW Act, which came into effect on 1 April 1946, made available $£ 120$ million over ten years, with an annual limit of $£ 17.5$ million, of which $£ 1$ million could be spent on research. These figures enabled the planning of long-term development, with the realization that projects would initially require a smaller share of the funds because expenditure would increase as the schemes progressed; therefore, more than one-tenth of the overall funds could be granted in any one year. ${ }^{18} \mathrm{In}$ total, just over $£ 13.25$ million was spent in a combination of grants and loans under CDW Act provision between 1940 and 1947. The funds were split between residual Colonial Development Fund schemes, research projects, development and welfare schemes, and salaries and expenses accrued in the administration of the programmes, with the bulk of the amount, more than $£ 12$ million, being spent on development and welfare schemes. ${ }^{19}$ The CDW Acts also resulted in the creation of several research bodies and advisory boards. This included the Colonial Economic and Development Council, which was created by the Secretary of State for the colonies, Arthur Creech Jones, in September 1946 to advise on 'the framing and subsequent review of plans for economic and social development in the Colonial Empire' and on 'questions of general economic and financial policy'. ${ }^{20}$ In the post-war world, development was thus already established in the policy debates of the Labour Party. That it would continue to shape the party's approach to the future of the colonies was, in itself, unsurprising.

As well as mobilizing colonial resources for the demands of the metropole, colonial development could be directed at fulfilling the needs of the colonies themselves. Kathryn Tidrick, in her book on the relationship between empire and the English national character, highlights the transition from traditional British extractive imperialism to a different attitude, created through the 'erosion of the once sacrosanct idea that the colonies must be, if nothing else, self-supporting'. ${ }^{21}$ As Rita Hinden, the South-African-born Fabian economist pointed out, this focus on development funded only through locally raised revenue had historically meant that colonies became 'caught in a vicious cycle of low productivity, low revenues, and low expenditure', unable to afford public investment even when it might lead to higher profits. ${ }^{22}$ Tidrick draws a clear distinction between the 'old imperial system', whereby colonies had 'puttered along as virtually independent satrapies', and the new imperial attitude, which 'involved the Colonial Office intimately in economic planning for the empire' and 'forced the British government to take a more visible interest in colonial welfare'. ${ }^{23}$ 
This newfound concern for the living conditions of the colonial populations led to social welfare development that mirrored the contemporaneous implementation of the British welfare state. The development of health and education services was also supported by the provision of transport and communication services. This slow move towards developmental colonialism created a framework in which the post-war Labour government could engage with the British colonies. This was no mean feat, given the historic attitude of many Labour Party members towards imperialism as a global economic and political system. ${ }^{24}$ The Labour Party had engaged critically with colonial politics right from the beginning of its history; perhaps unexpectedly, this engagement was not framed around issues to do with labour or class-based inequality, but was more generally shaped by an understanding of 'the more purely moral case for human rights' and a critique of racial and political oppression through the colonial system. ${ }^{25}$ This framing of anti-colonial thought as a fundamentally moral issue, rather than as part of a broader structural critique, became central to the Labour Party's conception of its own relationship to imperialism - even when the party was itself an agent of imperial rule.

\section{The Fabian approach to empire}

In 1940, in response to the debates surrounding the Colonial Development and Welfare Act, the Fabian Society established the Fabian Colonial Bureau (FCB) in order to define clearly British left-wing thinking on imperialism. For twenty years it represented the most consistent left-wing intellectual response to the British empire, developing into an important policy group. It commissioned research, which was disseminated across more than sixty territories in a journal, Empire (from 1949, Venture); briefed Labour Party MPs, many of whom were asked to sit on parliamentary committees; and campaigned on issues including independence and constitutional progression, economic development, the exploitation of natural resources in the empire, and rural and urban land use. Many of the people involved in the creation of the FCB were to become influential in colonial government policy and academic study; as well as Arthur Creech Jones, who was its first chairman, Rita Hinden edited and wrote much of the FCB's journal; they were joined by Margery Perham, the influential historian and anthropologist, and W. Arthur Lewis, the development economist, as well as by Leonard Woolf, Frank Horrabin and Margaret Cole. To raise publicity for the organization, Creech Jones 
enlisted a panel of MPs to ask 'Questions in Parliament' on colonial issues, and the Manchester Guardian and the Reuters overseas correspondent were courted as sympathetic media contacts. ${ }^{26}$

The FCB was the 'sole political research group devoting its efforts to colonial affairs' during the period and, as such, had some public authority. The organization has been characterized as the 'only traceable Fabian influence upon the thinking of Members of Parliament' during Attlee's government (not least because of Creech Jones' dual role), and as the 'main inspiration' for Labour's imperial policies. ${ }^{27}$ The influence of the FCB was no doubt magnified by the previous lack of concentrated research within the Labour Party on imperial issues, which had been addressed only in the most 'cursory manner'. Within this policy void, the Fabians 'studied, debated, elaborated, criticised and honed down to desirable goals' the most vital colonial issues. ${ }^{28}$

The FCB certainly engaged in some blanket criticism of imperialism. For example, the prominent anti-colonialist author, and former Colonial Service medical officer, Norman Leys wrote a piece expressing anger at the social conditions of Africans in British territories, whom he believed enjoyed a 'place in society...nearer to that of chattel slaves than to that of freemen'. The group as a whole, however, fundamentally wanted to bring about a change, rather than an end, to British colonial rule in Africa. Leys himself shied away from promoting the dissolution of the empire as a solution to the problems he identified, instead suggesting equal franchise conditions between white and black communities in Africa as a way to address inequality. ${ }^{29}$ As a whole, members of the FCB exemplified the principle that it was possible to be anti-imperialist, in the sense of opposing imperial exploitation, without calling for the immediate decolonization of the British empire.

This accommodatory approach to imperialism became more politically expedient when the Labour Party, under the leadership of Clement Attlee, won the 1945 election and was forced to confront the reality of colonial rule. Rita Hinden wrote, in 1959, an outline of what Labour's options had been when it came to power in 1945 and inherited a vast colonial empire:

Enjoy it? No, that would have been a violation of socialist principle. Reject it outright, and so remain true to the anti-imperialism which socialists had always preached? Or, better still perhaps, accept the heritage, but with the determination to nurse and develop it for the advantage of its rightful owners till they themselves should have come of age? ${ }^{30}$ 
Colonial development provided the Attlee government with a way of engaging with the colonies that could be justified within the Fabian and socialist ideologies underpinning the Labour Party in this period, while maintaining a fundamentally paternalistic approach to colonial territories. This focus on development rather than the maintenance of colonial rule enabled the Labour Party to engage with the politics of colonialism while simultaneously critiquing others - including, importantly, the Conservative Party as a whole - for their supposedly exploitative and imperialist attitudes. This was a means of planning for an imperial future in which questions focused on the nature and quality of future engagement, rather than the nature of sovereignty. That debate took this form owed much to the assumptions that guided it within the FCB, reflecting a belief that the future was defined by looser bonds, and greater liberty, but not independence as such.

Before he became colonial secretary, in his work with the FCB, Creech Jones framed colonial development as part of a long-term trajectory that would eventually see self-government for the African colonies. He acknowledged that complaints about colonial exploitation were 'well founded' and that a critique of economic imperialism was fully justified; Africans had a right to 'bitterly complain' about the wealth 'drained' from the continent and the small amount returned from the 'huge profits' made from colonial goods. ${ }^{31}$ To rectify this, 'consultation and cooperation' with indigenous Africans was 'required in the planning of all future development', because local communities were knowledgeable about their own economies, infrastructures and societies. ${ }^{32}$ The FCB itself argued stridently against the imperialists who wanted 'to suggest that the British Empire is a blessing to the world, and, in particular, to the Natives'. ${ }^{33}$ Instead, the FCB promoted what it believed was a new attitude to empire, based on collaboration and cooperation between colonized and colonizers.

The FCB raised traditionally socialist concerns and applied them to the colonial territories. Creech Jones decried the fact that African wages were 'determined only by what is necessary to keep a body and soul together on a level as low as human existence can just manage', arguing that African agricultural workers would achieve acceptable living standards only when they received a fair price for the fruits of their labours. ${ }^{34}$ This rhetoric clearly echoed the earlier demands of socialists in the metropole. There was a focus within the FCB from the 1930s onwards on 'riots and strikes' within the non-self-governing empire, which did not 'suggest contentment' with the status quo and mirrored the political action taken by marginalized groups in Britain. ${ }^{35}$ Paul Kelemen, in 
his work on Kenya, has emphasized the development of 'trade unions, co-operatives and local government' as central to the 'specific contribution' of the Attlee government to 'post-war metropolitan thinking on Africa and on the colonial question'. ${ }^{36}$ Venture, the FCB journal, heralded in 1950 the 'existence of a thousand colonial trade unions with a membership of over 600,000' and celebrated the work of British 'trade union advisers who have brought the "know-how" of British unionism to the Colonies'. ${ }^{37}$

Writing in 1959, Rita Hinden summarized the interests of the FCB to include such typical Fabian and socialist priorities as

the establishment of trade unions and cooperative societies, schools and welfare services and the money to pay for them, grand projects of colonial development (and again the money to pay for them), irrigation, sanitation, the conservation of the soil, better prices for colonial products, [and] the establishment of new industries. ${ }^{38}$

These concerns, which included 'anything and everything that would relieve the pressing burden of colonial poverty', are clearly analogous to the welfare and labour issues that were demanded by Labour for British people in the metropole. ${ }^{39}$ They illustrate an identifiable left-wing approach to empire, which was co-opted into development policy in the post-war period by Creech Jones and an amenable Colonial Office.

Several historians have examined the connection between the Fabian Colonial Bureau and the Labour government's colonial policy in this period. ${ }^{40}$ Among others, Michael Cowen and Robert Shenton agree that post-war Labour governments' efforts at colonial development can be located in Fabian thinking, which they link to Joseph Chamberlain and the development of 'great estates' in the empire. Their article focuses on economic development, and investigates the role of Fabian ideology in formulating 'a doctrine of development which would meet the claims of liberalism within the contours of a socialist version of trusteeship'. ${ }^{41}$ Arguably, however, the Fabian influence is most discernible in social welfare projects. Decision-making about colonial development was governed by an ideological conviction that it was necessary to improve the standards of living for colonial populations in the short and long term, primarily as a method of creating self-sufficient colonies that could progress towards self-government. Creech Jones and the FCB fundamentally believed that territories were being held 'in trust for the native inhabitants', with the main aim of all colonial administration being 'to train the native inhabitants in every possible way, so that 
they may be able in the shortest possible time to govern themselves'. ${ }^{42}$ For the Fabians, colonial development was central to the creation of new democratic states.

Not everybody in government acquiesced in the Fabian ideals of social welfare development (over economic programmes), or progression towards self-government for the colonies. For many within the Attlee government, colonial development could be supported only if it was 'sufficiently remunerative' to justify British investment at a time of great economic difficulty. ${ }^{43}$ This is the wider ideological and practical context that led to the establishment of the Overseas Food Corporation (OFC), proposed by the minister for food, John Strachey; the organization was initially set up in connection with the East African Groundnuts Scheme in Tanganyika, perhaps the most infamous and ill-fated example of a post-war British colonial development project. As a response, the Colonial Development Corporation (CDC), supported by Creech Jones, was created to support 'development for new sources of supply of foodstuffs and raw materials from the Colonies', but again with a focus on profit for the metropole as well as development on the periphery. ${ }^{44}$ This type of mercantile development sat uneasily against the Fabian-inspired welfare programmes, and enjoyed only limited success. ${ }^{45}$ But the context in which colonial politics were being created, and the inherent tensions of bureaucratic politics, meant that these disagreements about the fundamental purpose of colonial rule had to be thrashed out between the Colonial Office, the Foreign Office, the Treasury and any number of other interested parties. ${ }^{46}$

In other words, many within the Attlee Cabinet were happy to support development that was aimed primarily at the economic progression of the metropole, although they were less willing to publicly admit that this was their main priority. Creech Jones, the Fabian Colonial Bureau and many within the Colonial Office, on the other hand, supported development policies that prioritized the needs of colonial governments and their populations (notwithstanding the thorny issues of minority government in the white settler colonies) over the desires and demands of the metropole. ${ }^{47}$ Frank Heinlein has highlighted the resistance by Colonial Office officials 'on moral grounds' to any development plans that might engender exploitation, or even the perception of exploitation, of colonial populations for British financial gain. ${ }^{48}$ In this way, development policies could be cast as a more 'moral' way to run an empire, which fitted into broader Fabian conceptions of how Britain should exist in the world. 


\section{Development and decolonization: managing the transition}

In this context, the Ministry of Overseas Development (ODM), which was established in 1964, can be seen both as the descendant of British colonial development policies in the first half of the twentieth century and the predecessor of British overseas development and humanitarian aid in the twenty-first century. It represents both a break in the narrativeas the first time that aid was delivered to a generalized set of recipients 'overseas' rather than to fellow imperial subjects - and a continuation of attitudes and approaches that were forged in colonial rule. Colonial development did not end with decolonization; instead, the metropole maintained its relationship with its former colonies through overseas aid and development programmes that clearly echoed the rhetorical and ideological approach to imperialism that was established during the postwar Labour government. ${ }^{49}$ This continuity was also evident in domestic party politics in Britain; throughout the second half of the twentieth century the Labour Party used the rhetoric of aid and development to identify itself as belonging to a particular tradition within foreign policy that could be understood as distinct from the Conservative Party.

The Colonial Development and Welfare Acts were renewed in 1949, 1950, 1955, 1959 and 1963; in addition, the Colonial Development Corporation continued to promote capital projects. These programmes were supported from 1961 to 1964 by the Department of Technical Co-operation (DTC), which was responsible for all technical assistance to foreign countries; alongside the DTC, the Commonwealth Relations Office controlled capital aid to Commonwealth countries, and the Foreign Office was in charge of all capital aid to foreign countries outside the Commonwealth. In 1964 these functions were all brought under one umbrella, when the ODM was created as an independent department by the first Labour government of Harold Wilson. The ODM represented the first British attempt to develop a cohesive overseas aid policy in a postcolonial context. It also, simultaneously, demonstrated how far British responses to the 'developing world' continued to be shaped by ongoing colonial entanglements.

When the ODM was created, its policies were clearly historically rooted in British imperialism, especially the post-war conception of colonial rule as enacted through social welfare and economic development projects. As I have argued, a section of the Labour Party self-consciously identified itself with an ethical approach to colonial rule, which it established through the rhetorical lens of Fabianism 
and in the context of ongoing debates about developmentalist colonial policies. By the 1950s and 1960s this approach had become more universally associated with the Labour Party as a whole, which was keen to define itself as having a specific approach to the colonies and former colonies. This was elaborated by key thinkers such as Barbara Castle, Tom Driberg and Judith Hart. For example, in one of Barbara Castle's electoral addresses in 1955 she criticized the Tories for spending $£ 5,800$ million on arms compared to $£ 69$ million on colonial development, and drew comparisons between these policies and their domestic approach, which also 'put wealth before social development'. Castle directly connected her views on overseas development to her broader political beliefs, writing that she was a socialist because 'people... are very much the same the world over: with the same needs and the same right to a decent life'. ${ }^{50}$ In this way, she worked to orient her approach to the developing world within the broader fabric of the Labour Party, which in turn served to exclude those from a separate political tradition.

The Labour approach to development in this period simultaneously demonstrated how far British responses to the 'developing world' were shaped by ongoing colonial entanglements. British aid was overwhelmingly concentrated within the Commonwealth, because Britain's sense of its own international duties and responsibilities remained closely tied to its recent imperial history. The Labour Party was keen to emphasize this continuity and maintain these ties with ex-colonial nations, as an internal positional paper makes explicit:

Perhaps Afghanistan, with a per capita income of less than $\$ 100$, is in greater need of capital investment than Ghana, whose per capita income is over $\$ 100$, but Ghana is our particular responsibility. If a choice has to be made, Ghana comes first... A multi-racial Commonwealth will not hold together for long if the mother country aids other states at the expense of its Afro-Asian members. ${ }^{51}$

Ghana, of course, had been officially independent from Britain since 1957, and had not been Britain's 'responsibility' for some time; the process of decolonization did not stop British governments, including Labour governments, continuing to conceptualize aid and development within the ideological framework and imagined community of the Commonwealth.

In this way, aid and development programmes worked to replace or replicate the old power structures and relationships of imperialism. At 
the same time, development provided a conceptual framework within which a modernizing Labour government could interact with colonies and former colonies, without undermining the party's rhetorical and ideological commitment to decolonization. As under Attlee, Wilson's Labour Party worked hard to ensure that its approach to overseas development was perceived as part of a broader Labour philosophy on politics and government. In fact, overseas development was characterized as fundamental to the Labour mission:

To the doctrinaire Socialist, the answer...is simple. We should participate wholeheartedly in the UN programme, even if it means increasing our own contribution to 2 per cent or more of our national income. What is economic aid, after all, but the global application of the basic tenet in the Socialist creed - from each according to his ability, to each according to his need? ${ }^{52}$

This type of rhetoric not only advocated for Labour to promote an active development programme overseas; it also drew on connections between Labour's foundational ideologies and overseas aid and development, which in turn served to create a connection between the Labour Party itself and these policies, both historically and in contemporary politics.

Overseas aid and development provided a framework for the Labour Party to talk about Britain's place in a rapidly changing world. In the early 1960s Barbara Castle and others within the Labour Party believed that the provision of British overseas aid was inefficient, spread as it was between several different government departments, and inadequate, given the urgent need for humanitarian, economic and technical aid around the world. In February 1964, eight months before the Labour Party would narrowly win the general election, Castle advocated passionately in the House of Commons for the creation of a specific government aid department:

We all dilate about the difficulties - and, heaven knows, they are immense; the amount of aid already voted is like a drop in the bucket of need, when we face it - but much more could be done. A Ministry of Overseas Development in this country...with Cabinet rank [would] show the importance which we in Britain attach to the challenge of the Development Decade... This country is full of warm-hearted people. They have shown this by their response to various voluntary bodies - Oxfam, Voluntary Service Overseas, and others. I believe that they would respond to this challenge if it was 
put to them... The wind of change is not blowing only politically. It is blowing economically, too, and it is for this potentially influential country to give the lead. ${ }^{53}$

Castle rooted state-led overseas aid and development within a broader context of both NGOs and transnational organizations, specifically citing the UN Decade of Development. She invoked recent imperial history - the 'wind of change' speech that Harold Macmillan had delivered in Ghana and South Africa in 1960 - to explain the need for aid at this particular time, locating British aid and development policies within the decolonization process. She also framed overseas development aid not as charity but as 'a vital factor' in the 'survival' of both Britain and the wider world; while this can be read against a backdrop of Cold War struggles for hearts, minds and resources in the developing world, it can also been seen as a call for the 'survival' of Britain's international role. Castle declared Britain a 'potentially influential country' in the field of development, a declaration that sits at odds with ideas of British post-war decline and hints at a further motive for aid and development policies beyond the continuation of colonial ties or a sense of responsibility for former imperial possessions.

Wilson's Labour Party worked hard to ensure that its approach to overseas development was perceived as part of a broader Labour approach to politics and government at home and in foreign affairs. In its 1964 manifesto, the party promised that a newly created ODM would coordinate both Commonwealth aid and Britain's work within the specialist agencies of the United Nations. Again, the manifesto drew upon classic Labour values to justify spending on aid: '[W]e believe that the socialist axiom "From each according to his ability, to each according to his need" is not for home consumption only.' The new ministry and the wider development policies were fundamentally presented as a way to deal with a newly postcolonial world; appearing in the manifesto under a larger section entitled 'A new role for Britain', with the subheading 'The end of colonialism', overseas aid was a way for Britain to take on a new role and thus to 'keep pace with the dramatic changes in the world scene'. ${ }^{54}$ This was an entanglement predicated on a long-running engagement with aid, and not fixated on concepts of sovereignty. By identifying itself with a progressive approach to the end of the empire, Labour could argue for a continuing role for Britain in its former overseas colonies without drawing accusations of neo-colonialism; this echoed attempts by Attlee's government to utilize colonial development to maintain British control over potentially volatile colonial citizens and territories, as well 
as reiterating ideas that British prestige was rooted in the maintenance of spheres of hard and soft power overseas.

As the first minister for overseas development, Barbara Castle oversaw technical and capital aid to both Commonwealth and nonCommonwealth countries, as well as scientific research and liaison with outside bodies. Both in the type of aid programmes enacted and in the language used to talk about aid and development, the ODM clearly drew on attitudes and expertise that were rooted in recent British colonial rule in the developing world. So, for example, in 1965 the department published an introductory report entitled 'Overseas development: the work of the new ministry', which stated that the motivation of British overseas aid was to 'help developing countries in their efforts to raise living standards'. This included 'reducing poverty and unemployment', but also 'fulfilling aspirations towards steady and continued social and economic progress' and thus 'the transformation of traditional societies into modern ones'. ${ }^{55}$ The rhetoric of 'modernizing' African, Caribbean and Asian countries, to restructure their societies in the model of Britain and other Western European nations, clearly drew upon Fabian thinking from the 1940s and earlier, as well as broader narratives of British colonial power from the nineteenth and twentieth centuries. While the Labour Party tried to frame its approach to the developing world within its wider progressive political policies, it is clear that the party also situated its approach within its own ideological history, which included far more collusion in imperial rule than it was comfortable to admit.

Under the Wilson government, the ODM funded development programmes around the world, though they were overwhelmingly concentrated in the Commonwealth and the few colonies yet to gain their independence. The ministry recruited some 2,000 people a year, including teachers, doctors, engineers, nurses, geologists, planners and economists, with an annual budget of more than $£ 200$ million despite cuts in the public spending allocation. ${ }^{56}$ In 1967 the Overseas Development Institute asserted that the ODM's work meant that overseas development aid had become 'an integral part of international relations and an important ingredient in international affairs' ${ }^{57}$ By 1970, Economic and Political Weekly reported, 'a remarkably well organised and articulate lobby' had been developed in Britain in support of overseas aid. That year Judith Hart, then Minister for Overseas Development, announced an increase in aid of 50 per cent over the next five years, which was greeted not with 'a quiet glow of satisfaction from the small group of aid specialists, and a snort from the Daily Express', but with demands from voluntary agencies, 
churches and other groups for an even more significant increase in spending. ${ }^{58}$ The Wilson government used this success to proclaim itself to be 'the guardian of those social values which market forces, left to themselves, will erode'; the identification of Labour with the 'moral' issue of international aid seems also to have been broadly successful among the electorate. ${ }^{59}$ This long-running colonial entanglement suffused Labour Party debates, with a focus on development considered more chiefly contingent than the issue of sovereignty.

\section{Conclusions}

This chapter has sketched out two examples of Labour's approach to overseas development, the first in the aftermath of the Second World War, the second, not even twenty years later, at a point when most colonies had gained their independence from Britain. The chapter has explored the ways in which development programmes were seen as preparation for independence - or to perform the idea of granting independence - or to manage the relationship between ex-colonies and the former metropole. For Arthur Creech Jones, and the Attlee government, colonial development policies were an 'ethical' way of doing imperialism; for Barbara Castle and Wilson's governments, development was a way of maintaining colonial ties in a postcolonial world and forging a new identity for Britain in a world without empires. In both periods, Labour governments cast aid and development as being fundamentally connected to the party's founding principles - whether Fabianism or socialist tenets of collectivism and labour rights. They imagined futures predicated on their own values, in which the contingent factor was the quality of and commitment to engagement, and not a broader focus on political sovereignty.

This rhetoric continued to be employed by the Labour Party throughout the twentieth century. For Tony Blair's government, in the late 1990s, overseas development became a fundamental plank in the newly proclaimed 'ethical' foreign policy, often in a way that served to deny or elide Britain's colonial legacy. It is tempting to see development policies moving smoothly from the Colonial Development Act of 1929 to the work of the Department for International Development (DFID) around the world today. The actual history of British development policy was more fractured, however. In its original incarnation, the ODM survived only until the Conservative victory in 1970, when responsibility for overseas aid was returned to the Foreign Office. When Labour returned to power in 
1974 it created a Ministry of Overseas Development again as an independent department. The Conservative government headed by Margaret Thatcher, in turn, restored control of overseas aid to the Foreign Office in 1979. In 1997 the Department for International Development was created when Tony Blair's government was elected with a landslide. It seems that, both during and after decolonization, the Labour Party maintained a belief in the importance of overseas development as something separate from foreign policy. More work needs to be done to address the ways in which the Labour Party has, historically, made a unique and conscious effort to associate itself with an 'ethical' approach to international relations, as well as examining exactly how the 'ethical' use of aid and humanitarianism was framed by the wider British political establishment and media.

There are also important questions to be asked about agency and the place of the developing nations themselves in this narrative. The British government, and the Labour Party specifically, vacillated on whether they wanted to implement development themselves based on their historic colonial 'expertise', or whether they wanted to facilitate development that responded to local requirements and demands in a way that would put power in the hands of local populations. In fact, it seems that, as imperial ties loosened and the duties of imperial rule were diluted, the act of granting aid and enacting development became more performative, and it became more important to emphasize Britain's role overseas and to justify continued British involvement in the developing world. For example, in 2009 the Conservative Secretary of State for development, Andrew Mitchell, announced the rebranding of DFID overseas as UK Aid, complete with a union flag logo. Mitchell stated that this was being carried out to make sure that 'emergency grain packets, schools and water pumps' could be 'easily and clearly identified as coming from the UK'; this would help Britain to receive 'the credit it deserves' for its overseas initiatives. ${ }^{60}$ Emphasizing British ownership of aid seems at odds with encouraging local agency over aid initiatives, but clearly delineates areas of British influence overseas and thus, presumably, is aimed at using this influence to strengthen British power and prestige on the world stage.

Pointing out that aid and development programmes, whether enacted by governments or NGOs, often reflect or even overlap with the ideology and rhetoric of colonial development programmes is not terribly groundbreaking. The fact that the relationships between ex-metropoles and ex-colonies continue to be structured by colonial entanglements is, after all, widely accepted. Nevertheless, the history of decolonization is often framed, both in scholarly works and in 
the popular imagination, as a moment fundamentally characterized by transition and change: revolutionary movements, the collapse of empires and the creation of new nation states. Unpicking entanglements and thinking about decolonization as a longer process, which started earlier and finished later than this narrative allows, can therefore be a fruitful exercise for historians. It also illuminates a debate in which the primary issue was not the discussion of sovereignty but the quality and capacity for constructive engagement. The history of aid and development, which starts at the high point of European imperialism and continues into the twenty-first century, and which represents a resistance to the end of imperialism, an attempt to manage that process and, finally, an attempt to maintain imperial entanglements after empires have collapsed, offers one possible framework for this discussion. 


\title{
'Oil will set us free': the hydrocarbon industry and the Algerian decolonization process
}

\author{
Marta Musso
}

1956 was a pivotal year in the entangled histories of North Africa and Europe. In June the negotiations for the establishment of the European Economic Community started in Brussels at the Château of Val-Duchesse, and they would continue until March the following year. In September the beginning of the outbreak of violence that went down in history as 'the battle of Algiers' marked the descent of the Algerian rebellion into open warfare. In October the nationalization of the Suez Canal Company by the most active African ruler, Egypt's Gamal Abdel Nasser, and the ensuing crisis that lasted until March, showed all the weakness of former European empires in post-war foreign politics. These facts are welldocumented developments in the history of the twentieth century. ${ }^{1}$ Less attention has been given, however, to another set of events that occurred in 1956 and that, at the time, was welcomed as a fundamental change for the economics and geopolitical position of Europe and Africa: the discovery of large reserves of hydrocarbons in the Sahara Desert.

The presence of hydrocarbons in northern Africa gave Europe, and especially France, a unique opportunity to develop a domestic oil industry. In fact, while the traditional production areas outside the Soviet bloc were a prerogative of a few large US companies (the so-called 'Seven Sisters'), the discovery of hydrocarbons in the Sahara on the part of French companies opened the possibility for European operators to develop a new oil district, closer to Europe and perceived as more protected than Middle East supplies. For France, this was not simply the occasion to boost its own domestic oil industry - the richest business of the post-war era - but to control a powerful geopolitical tool, and to 
retain its influence in North Africa. At the same time, for Algeria's Front de Libération Nationale (FLN), as for many newly independent governments, oil became the symbol and the basis of economic independence, its bargaining chip against the West and against France in particular. ${ }^{2}$ In this narrative of oil as power, two opposite views of the world's future alliance system unfolded. France tried to revive the idea of creating a Eurafrican space, an integrated system that would allow Europe to rise again as a global power thanks to energy independence. The Algerian fighters, on the contrary, promoted a nationalistic view of the oil industry against Eurafrica and against Europe, with the idea that oil would allow them to reverse the dependency pattern between Europe and Africa. In this complex political, military and economic scenario, oil companies played an intensively active role. Private and state-owned companies alike acted according to their own rules, interfering in the Algerian decolonization process through secret diplomacy, overt aid and mutual influences on the governments. Rather than promoting integration, the main effect of the hydrocarbon discoveries was to prolong the Algerian War and to aggravate the negotiations over the control of the Sahara, the one condition from which neither party was willing to give an inch.

This chapter aims to reconstruct the political and economic discourse around the Saharan reserves, from the moment of their discovery up to the Évian Agreements. The contingent visions of the future outlined during this period outline the importance of the oil industry in the Algerian decolonization process both on an ideological and a material level. The historiography of the Algerian War has generally focused on French and international politics, leaving non-state actors and the economic aspects of decolonization in the background. Given the fundamental importance that Algeria had in contemporary French history, and the messy political and social fallout of the war in both France and Algeria, it is perhaps of little surprise that non-state actors have been marginalized. Furthermore, national, diplomatic and even military archives are generally open and offer a vast amount of information; business archives are often more difficult to access. Reconstructing the history of the strategies of non-state actors, especially private companies, presents particular challenges, therefore. Yet, as this chapter will show, the role of non-state business actors was paramount in the unfolding of the war. In general, international industry followed the decolonization process closely, as shifting sands promised profits for the prudent. The withdrawal of traditional European control left open new territories in which to seize new economic opportunities; in effect, the Cold War could itself be read as a global competition to seize resources and new markets on the part of 
two opposite systems of power. ${ }^{3}$ While Algeria is an exception in the history of decolonization, because of its stronger ties to the metropole, the history of the oil industry in the Sahara shows that France was willing to accept Algerian independence as long as the new status of the country would not endanger French access to its oil resources. This was believed to be France's right not only because of its historical control over the territory, but also because of the sustained investments by which it had sought to develop the Sahara. Controlling these resources altered the contingent vision with which France plotted out Algeria's future. Maintaining this para-political entanglement became an important consideration for the French Republic. With that in mind, the difference between the political independence and the 'actual' independence of Algeria was very clear at the time, yet the latter was both much more elusive and much more difficult for France to accept.

\section{Europe's double dependency and the discovery of the Saharan resources}

The shape of the international oil industry in the 1950s and 1960s ably reflected the new world order that followed the Second World War. It promised its champions a political and economic prize, and seemed to be a vehicle through which to achieve Cold War dominance. Both the main powers had their own reserves, and their geopolitical influence meant that they could influence reserves that lay beyond their borders. This left little for Europeans to squabble over, and, as they sought to strengthen their position against the Soviet bloc, they tasked collaborative bodies with investigating the problem. In 1956 the Organisation for European Economic Cooperation (OEEC) published a report on the European energy needs outlook for the next decade. Its outlook was bleak: based on GDP and industrial growth projections in the OEEC area in relation to energy input, Europe's energy gap (the difference between total demand and indigenous supplies) was predicted to widen from 22 per cent in 1955 to 32 per cent in 1975. This in turn would mean increasing balance of payments problems and threats to the security of energy supplies, which could halt economic expansion and weaken the continent against the Soviet bloc. ${ }^{4}$

The energy deficit was a major headache for European political and economic actors. Between 1954 and1956 oil consumption in Europe had gone up by 20 per cent, a growth rate that did not seem to be slowing down in the short or medium term. ${ }^{5}$ As a consequence, oil 
imports were becoming an ever-growing burden on the balance sheets of European countries, and fears grew in parallel to the widening energy deficit that a sudden arrest in supplies would cause a new economic crisis. Forecasts expected total energy consumption in Europe to double over the next twenty years. ${ }^{6}$ The Hartley Report, commissioned by the OEEC and chaired by Sir Harold Hartley from the University of Oxford, suggested promoting domestic production through coal and nuclear energy, but this could be done only up to a certain point. It warned that the coal industry had little prospect of substantial increase, due to prohibitive costs, and that hydroelectric energy also would not plug the gap. The highest hopes were invested in nuclear energy, but the technology was still in its infancy and the electrical power it produced was not yet convenient. ${ }^{7}$ The most accessible and most efficient forms of energy in the decades to come would be oil and gas, which were very scarce on the continent. In the age of oil, Europe had become a territory of scarce energy resources. ${ }^{8}$

Throughout the 1950s and early 1960s the largest oil producer in the world was the United States, with 36 per cent of total production. The Middle East came second (24 per cent), followed by Venezuela (16 per cent) and the Soviet Union (13 per cent). The rest of the world combined accounted for only about 10 per cent of production. ${ }^{9}$ The Middle East was developing rapidly as the most important hydrocarbon area, however, not only as a producer (in 1964 it would surpass the United States) ${ }^{10}$ but as the largest basin of proven reserves (63 per cent in 1960, against 12 per cent in the United States, 6 per cent in Venezuela and 9 to 10 per cent in the Soviet Union). ${ }^{11}$ Furthermore, the United States was also the largest world consumer, with almost 500 million tons per year. From 1948 it had become an importer country, which had caused the Truman administration to implement a series of measures to limit overseas exports and to secure the largest quotas of imports from Latin America, which were seen as easier to defend than the Middle East in the case of a Soviet attack. ${ }^{12}$ In contrast, the communist bloc was able to provide for itself, with 130 to 135 million tons of annual production and consumption. ${ }^{13}$ This left Europe exposed as the world's third-largest consumer but producing only 3.5 per cent of its supplies. ${ }^{14}$ Once the United States had cut down on exports, Europe became inescapably dependent on Middle Eastern supplies for 90 per cent of its needs. ${ }^{15}$

Moreover, neither crude imports nor product sales were directly controlled by European actors. Supplies and markets were managed by a group of large Anglo-American companies that exerted an oligopoly outside the United States and Soviet Union, controlling more than 85 per cent of the rest of the world's fields and markets. ${ }^{16}$ These companies were 
five American enterprises (Standard Oil of New Jersey, Gulf Oil, Texaco, Standard Oil of California and Socony Mobil) and two European concerns (British Petroleum and Royal Dutch Shell). At the end of the 1920s, in order to stabilize the market and avoid overproduction crises, these large companies had accepted each other's relative standing both in the downstream sector (refining and marketing) and in the upstream sector (prospection and extraction), establishing a cartel through a series of informal but rigid pacts. ${ }^{17}$ This system created a seller's market in which prices and flows were established by the cartel, with very little room for free markets. ${ }^{18}$

The world's largest globalized industry by value was thus dominated by a strong oligopoly, which guaranteed stability in the market by controlling the supply of this vital asset. ${ }^{19}$ It caused some consternation in US administrations, however, and even more in Europe, where the cartel controlled between 60 and 90 per cent of the oil market. ${ }^{20}$ As Paul Frankel, the most important expert on the oil industry at the time, ${ }^{21}$ wrote,

[T] he oil companies involved have become, almost in a state of absentmindedness (a state of mind allegedly responsible for the formation of the British Empire), international institutions which perform a vital role for all the countries involved. At the same time they remain unmistakably private enterprises, responsible for and to their shareholders. ${ }^{22}$

Outside the cartel, only a few independent US companies were able to carve out niche pockets in the extraction and marketing of oil. These companies were relevant domestically both for production and marketing, but they did not have access to relevant oil fields outside the United States and therefore had a much smaller importance internationally. In effect, as Frankel noted, 'the only truly independent oil company [Standard Oil of New Jersey] is more balanced and self-sufficient than any other, depending on no one for either supply or disposal'. ${ }^{23}$ In 1960 Standard had a turnover of $\$ 8.9$ billion, half that of the French state. Shell, the second largest, owned a 10-million-ton tanker fleet, twice as big as the French merchant fleet. ${ }^{24}$ These non-state actors were titans in their own right.

A third category of oil companies was state-owned enterprises (SOEs), at the time almost exclusively European. They mostly conducted research within the national perimeters and in colonial territories, or they focused on the downstream sector, buying crude from the cartel and selling it on at national level, thus exerting some influence on domestic prices. The power of these companies was very limited compared to both the cartel and the US independents: in 1956 the American independent 
Sinclair could count on a capital of $\$ 100$ billion, while the Compagnie française des pétroles (CFP), the largest European SOE, had capital of only F34 billion. ${ }^{25}$ Before the Second World War European governments had not been excessively concerned with the power of the cartel, partly because oil was still much behind coal as an energy source, partly because the supplies had always been reliable. On the contrary, the US administration had fought to break the oligopoly tendencies on its domestic market. As the status of oil as a fundamental resource became evident, however, together with the economic and political power of the cartel, European states became concerned by their double dependency on Middle Eastern supplies and Anglo-American control over the industry. The importance of SOEs seemed to offer some corrective for the diminished status of Europe both in the Cold War and the energy markets.

This was the global energy paradigm in January 1956, when French probes finally struck oil in the Sahara. Hopes of discovering important new fields in the desert had been chased by the French government since the early days of the European oil industry; in the 1920s a geological study had suggested the possible presence of substantial quantities of hydrocarbons. ${ }^{26}$ After the Second World War France became the most active European country to promote the development of a national oil industry, with the Sahara providing a natural place to look for new reserves. In 1947 the Bureau de recherche de pétrole (BRP), the body that coordinated France's oil policy, launched a vast research campaign in the area. Four companies were created to explore around 150,000 square kilometres: SN REPAL, entirely state-owned and controlled by the BRP and the General Governor of Algeria; CFP-A, jointly owned by CFP and two French financial groups; the Compagnie de recherche et d'exploitation de pétrole au Sahara (CREPS), controlled by the state-run French concern Régie autonome des pétroles (RAP) with a minority participation by Shell; and Compagnie des pétroles d'Algérie (CPA), 35 per cent controlled by the BRP and 65 per cent by Shell. It is important to specify the ownership of the companies because the French oil code at the time was very strict: foreign companies were allowed to invest only through joint ventures with French bodies, and, though it was not specifically stated, no foreign enterprise could hold the majority of shares in a consortium. Shell was to remain the only exception, principally because of the personal relationship between Pierre Guillaumat, head of the BRP, and Shell's CEO at the time. This was to become typical of the cooperation between the French state and industry, which 'enabled targeted investment to be realized and guided by para-political interests'. ${ }^{27}$ The French government was hoping to develop the Saharan resources on an autarchic basis, but 
the extreme working conditions imposed by the desert and the complex geological structure of the subsoil did not make the area desirable to the international oil industry. By choice and by necessity, the French state had invested most of the capital in the research campaign. Finally, after four years of exploratory drilling, the efforts paid off: in January 1956 CREPS found 100 million tons of oil reserves in Edjeleh, in south-east Algeria; in June SN REPAL discovered the oil fields of Hassi Messaoud, with 600 million tons of proven reserves, and in December gas at Hassi R'Mel, one of the largest gas fields in the world.

France went from being the European country with the largest energy deficit to a significant producer country. ${ }^{28}$ This would become even more important over the coming months as the Suez Crisis unfolded. In order to be considered a producer country, however, France needed to ensure that the Sahara remained within its imperial borders - an idea that was increasingly contested by 1956 . As Algerian politics became more strained, and nationalist demands more sharply stated, the boon of energy resources were imperilled by a very different vision of the future.

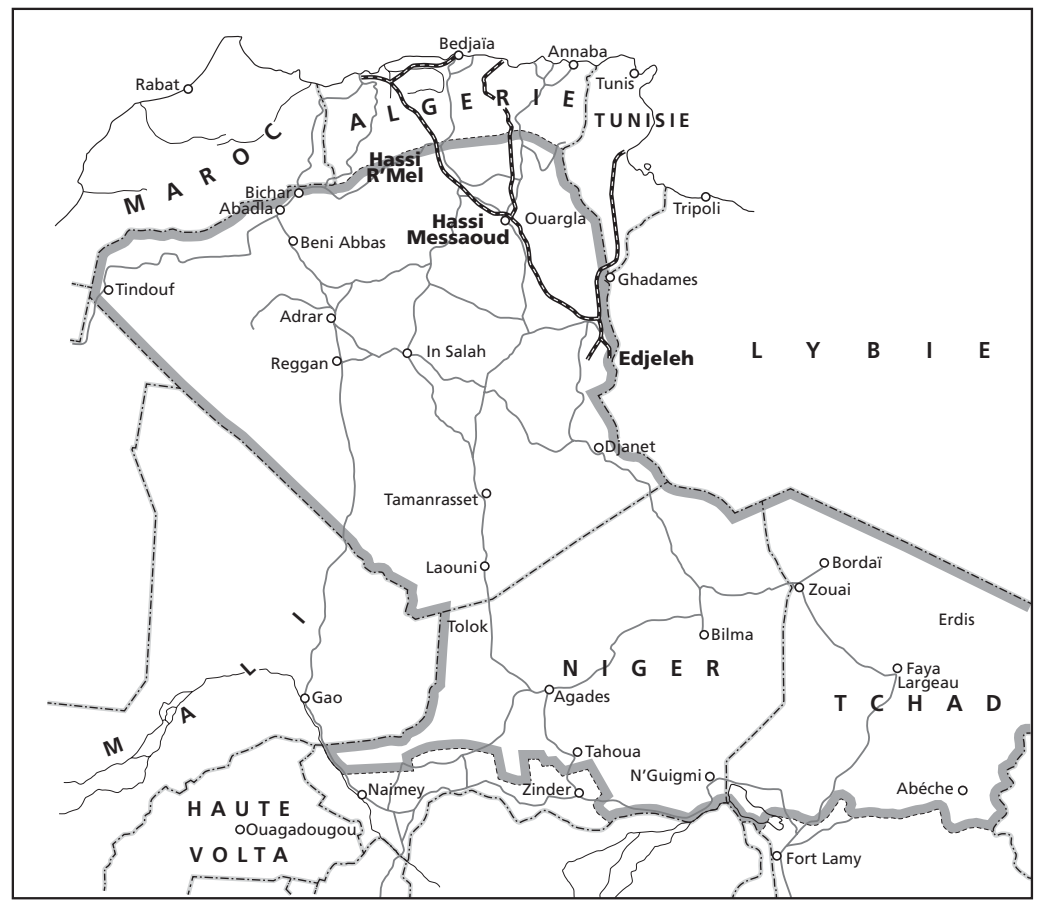

Figure 2 Map of newly discovered North African hydrocarbon fields (in bold), 1962 


\section{Controlling the Territoires du Sud: a new Eurafrica}

Up to the end of 1956 the Sahara remained chiefly a French concern. The fights against the Algerian nationalists were concentrated in the north of the country, and the desert was not of particular interest to the international oil industry, which preferred to exploit fields in the Middle East. Historically, Algeria comprised three départements, established in 1849 and all situated in the north (Oran, Algiers and Constantine). The conquest of the territories south of Mount Atlas only started in 1899, and was completed in 1902 with the establishment of the Territoires du Sud. These districts had a separate administrative system and a separate budget, which was under the jurisdiction of the General Governor of Algeria; effectively, they were a colony of the northern departments. ${ }^{29}$ Information on the area was scant: estimates of the population suggested somewhere between 1 and 4 million people, mostly nomadic Tuareg groups, of whom around 1.7 million lived within the French borders. ${ }^{30}$ The standards of living were lower than the rest of Algeria, with an annual average income calculated at 105 kilograms of wheat and F600 for the sedentary farmers, while the nomadic Tuaregs, who also owned tracts of land, could count on around 145 kilograms of wheat and F1,200. ${ }^{31}$ In the same year the average annual salary of a French manual labourer was F5,099. ${ }^{32}$

Nevertheless, it was widely known among the French authorities that the Saharan subsoil had a lot of potential, not just for hydrocarbons but also for iron, phosphate and other mineral riches. The desert had been at the centre of discussions on how to develop the area for a few years already, not only in terms of practical difficulties but as a motor to initiate and drive economic growth across the whole area. France was aware of the importance that Africa had in the new post-war geography, and it was determined to retain its African outlook while also building the European Community. In March 1957 Guy Mollet, the prime minister, was able to include the Overseas Territories in the European Economic Community, which entered into force on 1 January 1958. Paris was afraid that ignoring African demands for development would mean losing it to one of the superpowers: the United States or, worse, the Soviet Union. In contrast, the creation of a Eurafrican space geared to the Common Market could give Europe the possibility to rise again as a superpower. ${ }^{33}$

Already, in the years before 1956, a series of administrative bodies had been formed with this goal, such as the Bureau d'organisation des ensembles industriels africains (BIA), the European consortium for the development of African natural resources, and the comité des Zones 
d'organisation industrielle africaine (ZOIA). All of these were French bodies directly controlled from Paris, with the objective of coordinating mining exploration in French Africa and promoting the development of a local processing industry. ${ }^{34}$ The discovery of hydrocarbons significantly accelerated the process of administrative reforms. On the one hand, oil could provide France with the budget to implement a series of development projects; in the words of the French diplomat Erik Labonne, the Sahara could become the 'European Siberia'. ${ }^{35}$ On the other, it was fundamental to redefine the legal framework in which capital would be invested; between 1957 and 1958 a series of research permits expired and had to be reassigned. Both the will and the means of realizing a French foothold in African markets existed in the 1950s, and attempts to develop this imagined a Eurafrican future. The contingent factor of energy reserves remained both the biggest prize and the greatest liability in this quest, however.

Deciding on whose capital and which companies would be allowed in the Sahara was of fundamental importance for France's efforts to retain control over the area. A few weeks after the discovery of the Edjeleh oil field, in February 1956, Mollet declared from Algiers that 'the development of the desert is the great task of our generation'. ${ }^{36}$ Pierre Cornet, head of the financial commission of the French Union, wrote a book entitled Sahara: terre de demain (Sahara: land of tomorrow), published in October 1956. In this, he firmly supported reform in the area, stating that the development of the Sahara was a moral imperative for present-day France:

On our planet where, without truce, the mass of human beings multiplies at a dizzying speed, the immediate needs of their existence enjoin to the owners of unused space the duty to develop the resources or riches that can satisfy all human needs. ${ }^{37}$

With this new sense of urgency, a project that had been under discussion since 1953 was finally approved in January 1957: the creation of the Organisation commune des régions sahariennes (OCRS). The OCRS was an intergovernmental body for the management and development of the Saharan resources between the countries bordering the desert. ${ }^{38}$ Its main objective was the development of the oil industry and the necessary infrastructure, such as roads, landing fields and communication facilities. It harnessed the promise of increased employment opportunities for the local population, with assurances of an associated rise in standards of living. ${ }^{39}$ Under OCRS control, the borders of French colonial 
authority were redrawn; the north-east area of French Soudan (today Mali), and the north of Niger and Chad, all still belonging the French Union, were amalgamated with the southern Algerian territories, which were for the first time departmentalized in two provinces, Saoura and Oasis. These districts were put under the direct control of the newly established minister of the Sahara, and taken away from the administrative duties of the General Governor. This way, the Sahara was officially separated from the rest of Algeria and attached to the metropole. On a political level, the main objective of the OCRS was to create a strong juridical separation between the north and the south of Algeria; aware that the northern départements were slipping away from their control, the BRP and the French government wanted to create a legislative framework that would allow them to retain control over the Territoires du Sud even in the event of Algeria becoming independent. ${ }^{40}$ The creation of the OCRS was one of the signs that France was prepared to grant independence to Algeria, but not to lose control over what had been revealed to be the most strategic area of the former empire. The contingent factor governing France's colonial future was not the control of Algerian territory but the oil beneath its sands.

Retaining control over the Saharan riches thus meant that care had to be taken over the type of companies that could be granted extraction and selling rights in the area. Financial penetration by foreign industries, wrote Pierre Cornet, could become a Trojan horse to seize control over French territory: the origins of the capital for the development of the Saharan resources was therefore a primary matter. ${ }^{41}$ Initially, therefore, Guy Mollet's socialist government pursued an almost autarchic approach. Indeed, from the early 1950s the area had been subject to the envious gaze of foreign interests: since 1952 the British government had been requesting detailed information on the BRP's plans for the Sahara from its embassy in Paris. ${ }^{42}$ Up to 1954 the investments for developing the Saharan oil industry had mostly come from the state through the BRP; after this date, given the size of the investments required, two financial bodies were set up to channel private French investments. In March 1956 the minister of foreign affairs, Christian Pineau, openly criticized British and American encroachments on French territory and their desire to replace France in North Africa. ${ }^{43}$ Before the establishment of the Fifth Republic in 1958, French attitudes to development in Algeria oscillated between a nationalistic approach, which rejected incursions of foreign capital, and concern about the lack of foreign investment, both in terms of capital and of market outlets for the crude oil. The 
characteristics of the Saharan subsurface, the high costs of operations and a hostile climate deterred surveyors and made it very expensive to set up an oil industry; furthermore, the fact that foreign enterprises could not control more than 49 per cent in the joint ventures did not attract investments. Foreign companies also had to provide technical know-how and expertise; purely financial investments were not permitted. France lacked the know-how, the technology and the budget to run prospections in the Sahara alone, yet it was desperate to secure access to the area's hydrocarbons. Although the French government fancied foreign funds, it was not willing to abdicate control of this important resource in exchange.

There were many good reasons to justify this jealous guarding of control. First of all, the country wanted to develop its own national oil industry, in order to enjoy the enormous revenues that oil promised, and to develop the technical competence to run its own oil industry. Second, the BRP feared that the cartel, if it was let in, would implement the scarcity system that it was applying in the Middle East and Latin America, by strictly controlling production quotas and keeping crude prices higher. For the cartel members, the Sahara was mostly a competitor against Middle East oil, and it was in their interest to leave it underdeveloped. For France, in contrast, full-scale development of the resources and cheaper oil were an absolute necessity. A third reason, most important in the context of the Algerian War, was that French intelligence strongly suspected that the cartel was in contact with the Front de Libération Nationale. As early as October 1956 the aeroplane that was taking FLN's leader, Ahmed Ben Bella, from Morocco to Tunisia had been hijacked and the passengers arrested. Soon after the arrest the French press speculated that, among the documents confiscated from Ben Bella, there was an agreement between Aramco (Arabian-American Oil Company, the subsidiary of Standard Oil of California for operations in the Middle East) and the FLN for priority exploration and exploitation rights once the country achieved independence. ${ }^{44}$ The US ambassador in France, Clarence Douglas Dillon, denied the allegations, but also made sure that the documents would not be published. Mollet, for his part, lent weight to the rumours, even after it became clear that Algerian General Governor, Robert Lacoste, had leaked the information to the press without evidence. ${ }^{45}$

While documentary proof of the contacts between oil companies and the FLN is scant but present, it should not be a surprise that the attitude of the cartel took into account its wider position in the Middle East. Ben Bella's arrest caused many protests in the Arab world, and Aramco's vice president, James Duce, received a request from King Saud of Saudi 
Arabia to contribute to a fund for the prisoners. Officially, Aramco did not answer this appeal, but rumours about contacts between the company and the FLN continued throughout the war. ${ }^{46}$ This contributed to the mounting diplomatic tension between France and the United States with regard to Algeria, especially after then senator John F. Kennedy took an openly pro-independence stance in July 1957, soliciting President Eisenhower's administration to take a definite position in favour of Algerian independence and the internalization of the Algerian War. ${ }^{47}$ The United States, it seems, was no fast friend of French imperial interests in the Sahara.

For all these reasons, opening the Sahara's door to the cartel not only meant that France was letting the management of its immense resources devolve to powerful foreign bodies; it also meant opening the doors to industries that did not necessarily recognize French sovereignty over the territory and were independent enough to implement their own international policies. Nevertheless, the French oil elite faced a real dilemma, caught between the political and strategic risk of losing control over the Sahara and the need for the technical and financial means that only the American oil industry could provide. Furthermore, while concerns that the cartel would not adequately market Saharan oil were reasonable, its companies did have strict control over the European market. It would have been impossible to simply break this monopoly, especially given that the Saharan oil had higher costs of production and was therefore not competitive on the market. This explains why, during the very weeks that the Aramco/FLN scandal was unfolding and complaints against the international appetites over the Sahara multiplied, a delegation from the BRP was striving to persuade American oil companies to invest in North Africa.

In April 1957 Christian Pineau declared that France would not allow foreign companies to obtain research permits in the area; only three months later, however, Pierre Guillaumat contradicted him by declaring that, for the permits expiring between 1957 and 1958, there would be 60,000 square kilometres reassigned in the following months. ${ }^{48}$ His statement appeared to signal that France would adopt an open door policy. Nonetheless, the government was determined to keep the cartel out of its territories. In order to attract foreign capital and US technologies without surrendering to forces beyond France's control, the BRP tried to sign deals with the US independent companies only. While not quite as titanic as the cartel, American independents still had capital and technologies that were not available to the French oil industry. Because they did not have access to relevant fields outside their domestic territories, they would have a significant interest in fully exploiting the 
Saharan reserves, both in terms of extraction and of marketing. Likewise, they seemed more willing to accept the conditions imposed by the BRP, accepting minority shares in the joint ventures, and the inducement to sell the crude primarily in the franc area. Last but not least, although they represented an important lobby domestically, they did not have the international diplomatic leverage to implement their own policy. On the contrary, they could be excellent allies for France in putting pressure on Washington. ${ }^{49}$

The independent companies immediately showed a strong interest in the Sahara. In July 1957 the US Cities Service Company agreed to an exploration contract with SN REPAL. Sinclair Oil, Newmont Mining and Phillips Petroleum also applied for the new concessions in partnership with French bodies. By December 1957 six American and two British companies had been granted exploration concessions. On 11 January 1958 the first consignment of Saharan oil arrived under armed escort at the Algerian port of Philippeville, after travelling through a baby pipeline (6-inch diameter) from Hassi Messaoud to Touggourt, then via railway to the port of Philippeville and finally via tanker to Marseille. ${ }^{50}$ By April 1958 the Sahara was producing 1,200 tons of crude a day. ${ }^{51}$ The French desire to outsource development while maintaining control looked to be on the road to fulfilment.

While extraction took its first steps, however, discussions about the creation of a specific petroleum code for the OCRS became tangled up in difficulties. Throughout 1958 investments and the assignment of new concessions were slowed down by the lack of an appropriate framework. One of the main points of debate concerned whether or not to formalize the limit for foreign companies to own up to 49 per cent of shares. Imposing the limit would have automatically excluded the participation of the American multinationals to the Sahara, because the companies would not accept a joint venture with less than 50 per cent. In particular, this was the case for Standard Oil, which was interested in establishing a presence in the Sahara and to this end had been negotiating with CFP since 1957. A long debate ensued, against the backdrop of the Fourth Republic's collapse and the return of General Charles de Gaulle to power. Finally, a new petroleum code was approved in October 1958, though it was valid only for the Algerian provinces of the OCRS, and not for the rest of Algeria. This important clarification stressed the division between the territories, and sought to maintain political control of the development for the French Republic.

Soon after its promulgation, President de Gaulle made a trip to the Saharan oil fields, inviting the international enterprises to 
contribute to the development of the oil industry and the general economic growth of the area. On the same trip, de Gaulle announced the Constantine Plan, a general programme for the social and economic development of the Muslim population of Algeria; with this visit to the oil fields, de Gaulle linked the feasibility of the Constantine Plan to the development of the oil industry in the area. The new code was designed to attract foreign investment in the area, by introducing strong fiscal privileges and not placing a ceiling on foreign participation. ${ }^{52}$ In this matter, the new rule set the state free. The code was very favourable to the prospective concessionaires, more than the codes developed in the same period in Venezuela and Iran. ${ }^{53}$ At the same time, however, the state retained control over the origin of the capital invested and over possible changes in the internal control of the enterprises, with a substantial continuity in the BRP's approach of giving away exploitation rights only through joint ventures, and in exchange for technology transfer with France..$^{54}$

Soon after the promulgation of the new petroleum code, in January 1959, Standard, CFP and the government-controlled investment company Pétropar formalized the agreement for the creation of a joint venture in which Standard controlled 50 per cent of the shares. After signing a series of deals in a position of relative strength with the independents, de Gaulle and the BRP thought that the French position in the Sahara was strong enough to come to an agreement with the largest company in the cartel. In fact, de Gaulle was playing a subtler game. He worried that Standard might entertain talks with the FLN and be at an advantage should France lose the Sahara to the Algerian malcontents. Instead, de Gaulle hoped that, by coming to an agreement with the cartel, it would also be motivated to defend the status quo, thereby supporting French actions in the Sahara. ${ }^{55}$ France was seeking a corporate ally in a political conflict. The sole policy of these foreign companies, however, was to safeguard their investments and their interests in the area, regardless of political conflicts. As support for independence and the FLN was growing, interactions between Algerian nationalists and the oil industry in the Sahara intensified.

\section{The FLN and the oil industry}

With the new petroleum code setting the rules for the OCRS area and the entry of the majors, the Saharan oil industry boomed. Between 1959 and 1960 four new pipelines came into operation, and by 1962 the port 
of Bougie was handling more than 14 million tons of crude per year. Alongside the French and US companies, several European companies, from the United Kingdom, Germany and Italy, started to operate in the area. Production in the Sahara was expected to reach 20 million tons by 1963. ${ }^{56}$ As of March 1962, when the Évian Accords marked the end of the Algerian War, $£ 425$ million had been spent in the area to give value to the hydrocarbon reserves. ${ }^{57}$ At first glance, it seems that the oil industry was able to operate without any interference from the war. In reality, the construction of the pipelines and the general strategy for transportation was deeply affected by the conflict. As early as July 1956 all activities in the north had had to be abandoned because of safety concerns. A series of attacks on workers' camps, pipelines and railways required the deployment of military forces along all transportation routes. In November 1957 a team of CPA prospectors was attacked, and many were killed.

At the same time as these military actions against engineers and infrastructure, Algerian nationalists were monitoring developments in the Sahara very closely. Indeed, they were just as active as France in seeking the help of the international oil industry to affirm their rights over the desert. Echoing France's concerns about independence and control of the resource, the FLN repeatedly made clear to oil companies that it would consider any agreements made with French institutions to be void. They did show themselves willing to open the Sahara to international enterprises, however, as long as they recognized the sovereignty of Algerians over the territory. In an article dated 15 November 1957, the FLN official organ El Moudjahid wrote:

We understand that the development of such an immense territory requires technical and financial means that not even France can provide, let alone a nation subject to foreign domination for more than 125 years. [...] However, the Algerians intend to determine by themselves the conditions and modalities of these indispensable foreign contributions. [...] Only a free Algerian government will be entitled to approve such contracts and to grant concessions on the national territory. The foreign companies that have invested their capital in the Sahara and those who refer to the French government to obtain research permits are building...on sand. ${ }^{58}$

The approach of the FLN towards the hydrocarbon resources mirrored that of France, in both the geopolitical and economic spheres. Just like France, the FLN was firmly convinced that control over the oil industry would bring economic independence, prosperity and power to 
the nation; in other words, freedom. Also, just like France, the construction of integrated hydrocarbon transportation networks and a common market were considered a means of building a union with neighbouring countries, in order to gain more geopolitical power. For the Algerian nationalists, however, the Eurafrican perspective was utterly rejected, as well as that of being a part of the European Common Market. The OCRS was described as nothing more than a neo-colonial move:

France hopes to perpetrate in the Southern area a typical example of economic colonialism. In its traditional form, colonialism was characterised by an evident occupation that exploited the country; subsequently, it seized political power to ensure a regime of pseudolegality. Nowadays, an enclave system has replaced territorial occupation, allowing the intensive exploitation of the natural resources of the colonial area. The South of Algeria, with its economic and industrial potential, with its large energy resources under the sand, must now be extremely interesting for those who prefer this new direction of French colonialism. ${ }^{59}$

Against the dangers of economic neo-colonialism, the FLN pushed for a federation with Morocco and Tunisia to form a Maghreb Union, a project to be developed in parallel to the war of independence against France. Following Nasser's Philosophy of the revolution, the FLN claimed that, together with religion, oil was the unifying element of northern Africa, the weapon against colonial and neo-colonial powers. 'It is a fact that half the world's reserves of petroleum are still underground in the Arab regions,' wrote Nasser in 1952. 'The great catastrophe is that we do not know the extent of our strength. ${ }^{60}$ It was expected that the oil industry would provide the basis for joint industrial projects and for the development of an integrated economic system. In an article entitled 'L'indépendance...par le pétrole?' ('Independence...through petrol?'), El Moudjahid outlined that only a united Maghreb could use the Saharan reserves to promote an 'economy of liberation' founded on industrialization. ${ }^{61}$ A united Maghreb could count on a market of 25 million people, and an integrated energy network that would provide the capital to start the industrialization process.

It is interesting to note that the oil industry also attempted to present itself as a liberating force of development, whose mission was economic growth - providing the newly independent country promoted a free market and the free circulation of capital. In fact, developing countries represented perhaps the fastest-growing market for the oil industry. ${ }^{62}$ In the Petroleum Press Service, several articles were dedicated to the 
relevant role that the oil industry could play in the fight against global poverty. Capital formation was in fact one of the most urgent problems for developing countries, and the oil industry was a major contributor of capital, both through investments and through large sums paid to the local governments of producing countries. In 1957 alone the oil industry had poured \$2,200 million into the Venezuelan and Middle Eastern treasuries, without counting the income those treasuries received from further oil revenues. Overall, international organizations and governments from the free world had raised some $\$ 4,000$ million in funds for developing countries. ${ }^{63}$ 'The whole prospects of future peace and economic growth in all parts of the world would be seriously affected if the under-developed countries as a group were to fail to attain significantly higher standards of living within a reasonable time,' warned the Petroleum Press Service, which also invoked on behalf of the non-aligned countries 'a more enlightened attitude towards private capital'. ${ }^{64}$

Interestingly, up to the end of the war El Moudjahid barely discussed the possibility of nationalizing the oil industry. With regard to the private foreign industry, and especially the cartel, the attitude of the Algerian nationalists was similar to that of France. At times, the outwardly socialist El Moudjahid called for strong state control over the industry, showing antipathy for the cartel and the large multinationals. Indeed, in 1959 Algerian protests against penetration by Standard looked very much like the protests being simultaneously aired in the left-wing French press. On the other hand, the FLN did not want to antagonize forces that could become powerful allies. For this reason, while conducting sabotage and various other attacks, the Algerians also kept up their pronouncements that promised the oil industry very good deals on independence. In 1957 the French secret service, the Service de documentation extérieure et de contre-espionnage (SDECE), wrote that the FLN had secretly contacted foreign oil companies and reassured them that an independent Algeria would seek their collaboration and recognize their legitimate interests in exchange for their help. ${ }^{65}$ As we have seen, however, what the SDECE was reporting in its classified dispatches could also be read openly in the pages of El Moudjahid. The ambiguities of the Algerian position were every bit a product of gamesmanship, as were the French government's conflicting desires. Both saw oil as the contingent force that governed their vision of the future, and both sought to find corporate allies in this political war.

In this tug-of-war for the oil industry's favour, France gained an important advantage with the agreement between CREPS and the Tunisian government for the construction of a pipeline between the oilfield of Edjeleh and the Tunisian port of Gabés. ${ }^{66}$ The agreement caused a diplomatic 
incident between Tunisia and the Algerian nationalists and compromised the federative process in North Africa. Thanks to this pipeline, France found an alternative route to transport the oil to Europe without having to cross the war-ravaged north of Algeria. For the FLN, the agreement represented a stab in the back. In an open letter to the Tunisian government, it protested that, by signing a deal with a French company, Tunis had implicitly recognized the right of France to dispose of Algeria's riches, and was therefore taking the side of the colonizers. The FLN warned that it considered the contract equivalent to hostile military action against Algeria, because it severely undermined its strategy of sabotaging oil facilities. Furthermore, the agreement showed that Saharan oil could be immediately available, even with the war, and this incentivized international capital to side with the colonialist powers, damaging the struggle of all countries fighting for independence ${ }^{67}$ Each point scored in this game had broader ramifications in the battle raging over political control.

By the end of August 1958 the pressures of war forced the Algerians to back down on the pipeline crisis. El Moudjahid reported an official declaration of the FLN saying that, while the French-Tunisian agreement had 'deeply affected Algerian's public opinion and deteriorated the NorthAfrican front, the common action and Tunisian solidarity to the Algerian cause would continue notwithstanding the difference of opinion on the pipeline'. ${ }^{68}$ Any mention of implementing a common energy policy in the area disappeared from the pages of the newspaper, however. Diplomatic relations could continue in the circumstances, though the political fallout altered the future vision of independence. The federal project was undermined, in part, by relationships that fractured over oil and international investment. This influence on the future shape of Algerian sovereignty, and its envisaged relations with its neighbours, was shaped by the actions of non-state actors, and the incursion of commercial interests into geopolitics. The 1958 agreement with Tunisia was undoubtedly a victory for France, yet the FLN was also able to turn contacts with the oil industry to its own advantage. In particular, as will be analysed in the next section, the Italian national oil company was a precious ally during the peace negotiations in the town of Évian.

\section{The Évian Agreements and oil}

After the Algerian population had voted in a referendum early in 1961 to accept de Gaulle's proposal for self-determination, French-Algerian negotiations officially started on 20 May 1961, resuming several times 
before concluding in March 1962. For France, the main objective was not to be expelled from the desert, in order to maintain both the right to test nuclear weapons and control over its oil undertakings. ${ }^{69}$ De Gaulle tried to hold on to sovereignty over the Sahara till the bitter end, by proposing several reforms of the OCRS in the direction of a more internationalized management between France and African countries, including Algeria, Tunisia and Morocco. ${ }^{70}$ In order to favour the negotiations, in June 1961 the OCRS rules were changed so that 25 per cent of oil revenues would go to the Algerian Development Fund for the northern department; for the Algerians, however, full sovereignty over the southern provinces was non-negotiable. ${ }^{71}$

The position of strength from which the Algerian delegation, led by Belkacem Krim, operated was in part due to the fact that the Italian national oil company, ENI, was acting as a secret adviser to the FLN. ENI had been the main rival to France in the Maghreb area since the independence of Tunisia and Morocco in 1956, taking advantage of its diplomatic position as an alternative to the former colonial power to sign important agreements with both countries. France had formally protested to the Italian government over these contracts, considering them a foreign interference in the French area of influence. ENI went as far as refusing an offer to collaborate with France in the Sahara, openly proclaiming that it would enter the southern territories when the war had ended..$^{72}$ The involvement of a rival state-owned enterprise showed that France could not expect to have things its own way, and revealed the complexity of this brand of diplomacy. Its own enterprises had fought hard to carve out a niche for themselves, between the cartel and the independents, and France had hedged its approach against the competing nationalist demands. The Italians had followed this process with interest, however, envious of the space being opened up by the BRP. As such, ENI had been looking for a way into this contested marketplace for some time. Presenting itself as a rival to the colonial power meant that it could appear somehow neutral, shorn of the European symbolism that France carried with it, and that had scared off the FLN beforehand. This peripheral diplomatic manoeuvring cast a shadow over the future of France's vital interests, and the aspirations of Algerian nationalists.

During the negotiations at Évian, ENI provided the Algerian delegation with geostrategic intelligence: it shared detailed information on the state of the industry in the area, and consulted on the contracts and technicalities of the industry. ${ }^{73}$ ENI's information had been gleaned from various negotiations with the BRP, which included a trip to the Hassi Messaoud area. ${ }^{74}$ According to Mario Pirani, ENI's representative 
responsible for relations with northern Africa, the FLN's approach to the Sahara problem had originally been shaped by the Italian company's suggestions. While agreeing with the Algerians that they should not give up on sovereignty, ENI suggested that, in order to promote good commercial relations with France after the war, Algeria should agree to a shared management of the resources through a common agency. ${ }^{75}$ Otherwise, if France decided to cut imports from the Sahara, the Algerians would be left without the most important outlet for their oil. ${ }^{76}$

Whether or not it was the Italian company that had been the first to suggest this solution, the Évian Accords that ended the war on 18 March 1962 were indeed based on the creation of a joint French-Algerian Organisme technique de coopération saharienne. This certainly seemed to follow the pattern of the Italian advice. Algeria obtained full sovereignty over the southern territory, and France made a commitment to provide the technical, financial and cultural assistance to promote the economic and social development of the newly independent state. ${ }^{77}$ In exchange, France maintained all the rights of prospection, research and transportation that had been granted previously. Furthermore, for the next six years French companies would have precedence on concessions over any non-French and non-Algerian operators for equal proposals. While permit assignment remained the government's prerogative, the Organisme technique de coopération saharienne would manage the applications and draft the reports to assist in decisions. All in all, the accords are usually considered a victory for France, at least with regard to the oil industry. Even though legal sovereignty over the Sahara passed to Algeria, the new government committed to continue on the path laid out by France, and to maintain its interests unaffected. ${ }^{78}$ This sense of security is confirmed by the fact that, throughout the negotiations, French and international companies ran business as usual: in December 1961 the company CAMEL was established to transport gas from Hassi R'Mel; in March 1962 three new findings were announced. ${ }^{79}$

Nevertheless, the Organisme technique de coopération saharienne was a very weak body from the beginning. It was soon ousted by SONATRACH, the Algerian national oil company, established in December 1963. Just a few months after the declaration of independence sixteen of the companies operating in the Sahara established a consortium to build a third pipeline, connecting Hassi Messaoud to Arzew. The Algerian government refused permission to construct the pipeline, and assigned the works to SONATRACH. Unsurprisingly, the consortium companies did not accept being ousted by the newly established state company, and swiftly appealed to international arbitration. ${ }^{80}$ This 
froze the negotiations between the Algerian government and France for nearly three years, until a new agreement, the Association coopérative, or 'Ascoop', was signed in July 1965. This second treaty granted more privileges to the Algerians while leaving the Saharan code in place. Both Algeria and France trumpeted the agreement as a new model of statestate contracts between a consumer and a producer country, with oil as the basis for further cooperation and development projects between Algeria and France. Despite this optimism, however, the Ascoop was also destined to be short-lived. Disagreements immediately arose over the revision of the taxation system for oil revenues, scheduled for 1969. SONATRACH continued to seek, and continued to privilege, commercial and technical agreements with other countries rather than France, with the clear intent of differentiating its market outlets and acquiring technical competences independently. Cooperation had its limits, and neither party seemed willing to damage its own interests for the sake of progress.

The best-laid plans of negotiators were further undone as turbulent international events eroded French claims, and weakened the outlook for the Ascoop. During the Six-Day War between Israel and its Arab neighbours, in 1967, the Algerian government seized the moment to nationalize the American and British infrastructures, thus quadrupling SONATRACH's assets. Neither the British nor the American governments intervened, for fear of escalating the conflict. Most importantly, Algeria joined the Organization of the Petroleum Exporting Countries (OPEC) officially in 1969. Thanks to coordination with the other producer countries, the Algerian government gained the upper hand in the negotiations. When France refused to agree to new selling prices unilaterally imposed by Algeria in 1971, at the end of general negotiations between OPEC and the international oil companiestheAlgeriangovernmentdecided toend theAscoopagreement and to nationalize all the oil assets in the country, taking full control over the foreign presence in the Sahara. Contrary to what the French government had hoped, its state companies lost the most in Algeria. ${ }^{81}$ As for ENI, the sudden death of the company's president in a plane crash in October 1962 had caused a political and financial storm that forced the company to reduce its independent activities in northern Africa, and to simply sign a deal with Standard to buy Libyan oil. ${ }^{82}$ Neither state could break the cartel, and neither saw satisfaction through its manoeuvring in the Maghreb.

As the French politician Robert Bisson observed, the Eurafrican dream of a third bloc of power built on its mineral wealth and energy self-sufficiency died with the Évian Accords and the acknowledgement 
of Algerian independence. ${ }^{83}$ This failure was attributable not to African autonomy, however, but to the earlier inability on the part of French governments - probably the impossibility - of accepting a backward step in favour of new relations with Algeria. These new relations envisaged the development of a new oil production area independent from both the Soviet bloc and the US-dominated oil industry, yet the ongoing political tussles, and the guarded desires of all the parties involved, meant that complex entanglements could be undone only by cutting the knot.

\section{Conclusions}

In October 1957 the former freedom fighter and journalist Claude Bourdet published an article in France observateur entitled 'Sahara, no oil without peace'. In the article, Bourdet argued that the plan for developing the oil resources of the Sahara without first ending the Algerian War was just irrational propaganda:

The French were getting tired of this war, perceived as a useless waste of lives and of money. [...] It became important to the establishment to wave the flag of oil: 'Sure the war is expensive, but at the end of the day it is an investment to protect the Sahara. What are F700 or F1,000 billion per year, compared to the oil that will soon fertilise France? ${ }^{84}$

The great names of French capitalism, which had invested a lot in the companies seizing the land, needed to save what Bordet called 'their speculations'. Instead, France passed up the opportunity to use the Saharan resources to start the peace process, so that oil would become a vehicle for shared wealth between France and the independent African countries, including Algeria. Oil became the contingent factor that fundamentally separated the French and Algerian visions of the future, rather than the bond that could foster a lingering entanglement.

The French government showed itself willing to open its door to American companies, hoping that the US administration would thus back French interests in Algeria. Yet, despite all this scheming, Saharan resources were being handled with a mixture of short-sighted egoism and consumerism that did not take the local population into consideration. In a desperate bid to retain its resources, France was forced to change the motto 'No oil without a French Sahara' into 'No oil without peace'. ${ }^{85}$ Otherwise, warned Bourdet, when American companies took an interest 
in the Sahara they would indeed pressure Washington, but to end the war, not to continue it on the side of France - something the minister of the Sahara, Max Lejeune feared, saying: 'And it will be their peace, not ours. ${ }^{86}$ This chapter has explained, on the one hand, the hopes for economic integration invested in the oil industry, especially because of its tendency to favour long-term agreements and coordination between different actors. On the other, it has exposed the problem of legitimacy for France's influence in Africa, eroded at the expense of the globalized American industry. French development of the Sahara's oil was characterized mostly by the rush to seize as much control as possible, without creating solid bases for development. The oil industry in the Sahara did not bring Africa closer to Europe, barring short-term agreements wrought through tense negotiations; nor was it possible, at the time or in the subsequent forty years of European history, to develop a common energy policy. Beset by clashing visions of the road ahead, the decolonization of Saharan oil became a lost opportunity in the construction of an illusory Eurafrican dream. 
Section 2

Contingency 



\title{
4 \\ Future imperfect: colonial futures, contingencies and the end of French empire
}

\author{
Andrew W. M. Smith
}

Books can be objects as well as texts. At times, their material nature can speak of their cultural and political provenance just as much as the ideas contained within them. I found, perhaps, the clearest sense of this chapter tucked in the pages of an old book ordered online from a secondhand shop in Perpignan. It arrived in an envelope festooned with stamps bearing the portrait of Francis I, originally painted by Jean Clouet around 1530. This Renaissance monarch is perhaps remembered best as a 'great patron of the arts', ${ }^{1}$ yet he was also a significant force in expanding the horizons of France's early empire. ${ }^{2}$ Aptly, the envelope contained an aged and battered-looking copy of Le destin de l'Union française (The future of the French Union), written by Paul Mus and questioning the fate of that self-same empire some 400 years on. ${ }^{3}$

If the book's title was suggestive, its date of publication made it positively tantalizing. Released in 1954, the book poses important questions at an awkward moment of French imperial history. At first glance, its pages were frayed. In fact, they were largely uncut, and actually reading the book became as much a craft project as an act of research. But as I worked through these pages, slicing each with a blade to unlock its contents, a piece of the original marketing material tumbled out. This relic of its original release was a yellow (and yellowed) half-sleeve, with two words written prominently upon it: Indochina, and Africa. The word 'Indochina' is roughly crossed out with a stylized printed cross, while 'Africa' bears a question mark beside it. In fact, much of this chapter lies in the odd feeling that came of reading those two words. Juxtaposing the simple effacement and the lingering 
question highlighted an uncertainty that existed for only six years after the book's release.

This was a book being sold on its timely nature. With 'Indochina' emblazoned across the cover, it knowingly played on popular concerns about the French military defeat at Dien Bien Phu in May 1954, which marked the decolonization of Indochina. Invoking the fate of France's African colonies only exacerbated the tension. The publisher, Seuil, was using popular anxiety as a means of seizing the attention of readers. Evidently, France would cede her African territories between 1960 and 1962, answering the implied question and confining the future of the French Union to the scrapheap. That shift in perspective makes an obvious point about chronology, but raises more nuanced questions about contingency and perspective. By revisiting the conditional in this context, we get a real sense of its true identity as the future imperfect tense.

This piece of marketing material started a process of thought that drew me increasingly to wonder about divergent visions of the future during the 1950s: how confident projections became negotiated settlements, and imagined futures faded to difficult realities. The idea of 'what was going to happen' ineluctably shaped the ability of ordinary people to respond to these challenges and to conceive of their present. ${ }^{4}$ To explore this, I set Paul Mus' book against two other documents that seemed to complement its distinctive historical qualities: extracts from children's homework, gathered by a late colonial administrator seeking out dissent; and a summative report produced by a colonial governor at the end of his role, reflecting on his experience and political challenges to come. These three documents cut across categories to consider the questioning voices of commentators, children and colonial officials. With each document, we can learn more about the conditional questions posed by recreating the ideational context in which these questions were formulated. By reading along the grain of the archive, the historian accentuates the granular nature of the object of enquiry, and can make some attempt at the 'articulation of perspectives'. ${ }^{5}$ In this vein, we can consider, in the words of Ann Laura Stoler, 'colonial archives as sites of the expectant and conjured - about dreams of comforting futures and forebodings of future failures'. ${ }^{6}$

To consider the concept of colonial futures and contingencies, this chapter will analyse three specific documents in historical context. All these documents date from 1954 to 1956, all concern French involvement with sub-Saharan Africa in this late colonial period, and all offer some vision of the future untainted by our retrospection. This process of investigation aims to analyse the sources and their expired contingency, 
illuminating the possibilities they consider and the processes that constituted them. ${ }^{7}$ All three of these sources can be read against the grain of the archive. By considering the provenance of each document, I am also engaging in the process of, as Antoinette Burton terms it, 're-materialising the multiple contingencies of history writing'. ${ }^{8}$ Each of these documents has its own contingent story, relying on a certain serendipity in the archive. Yet serendipity belies agency. The ability of each to illuminate the concept of contingency in the late colonial state stems, in part, from their own material histories. This seems, at first, an intuitive observation, and reflective of common sense and good historical practice. Nevertheless, in trying to recover this expired sense of contingency from the unknowable, historical heart of the moment, we are drawn into a reflection on the sort of 'colonial common sense' described by Stoler. This 'common sense' governed things that were often not recorded, not because they formed some great secret or hidden truth but, rather, because they were commonly held and intuitively related to contingent factors that contextualized these impressions. ${ }^{9}$ By considering the research story behind each document, I am outlining the context of my own enquiry into the historical constellations that shaped these visions of the future, and the expired contingencies with which they engaged. ${ }^{10}$

Common sense held within it an internal logic of colonialism and power, and this is reflected in the archival collections that sprang from it. It is also reflected in the implied selectivity of documents that did and did not survive, whether through 'conspiracy' or 'bungle'. ${ }^{11}$ Within this search for expired common sense are examples of how some voices can be excluded and silenced from historical memory. ${ }^{12}$ The potential for incompleteness necessitates an acknowledgement of when we are attempting to work with fragments, and to 'mend the torn fragments of the past'. ${ }^{13}$ This is crucial when recreating the intellectual climate of the late colonial state, both among its critics and its defenders. In his piece On the concept of history, Walter Benjamin criticized the temptation for historians to 'tell the sequence of events like the beads of a rosary'. ${ }^{14}$ As observed by Todd Shepard, the end of the 1950s 'gave birth to the notion that "decolonization" was a causal force with an all but irresistible momentum'. ${ }^{15}$ The momentum transformed material produced during that time, and contributed to the way in which historians read the period itself. When Stoler advocates reading 'along the archival grain', it reflects this acknowledgement of material that has garnered a retrospective value. It is necessary, therefore, to consider not only the material but the methodology for gaining access to colonial futures and contingencies. 
Working against the teleological assumptions of history has opened up important discussions about the material we use to construct histories of the past, and, in particular, how people in the past considered the future. One of the most difficult aspects of recovering these past visions is in reconstructing an ontology of the common sense that surrounded them. We can focus our lens on a broad scope of the period, but much of our understanding of 1954 and the fall of French Indochina, for example, is conditioned by our understanding of its proximity to 1956 and the devolution of political power in the significant legal reforms of that year. Yet further, we can look to the fall of the French Fourth Republic, and de Gaulle's tenure during the unravelling of empire that followed from 1958 to 1962 . In looking at these documents, I am charting a path trodden by moderates, closer to the establishment and far less ambitious in their imagining of the future than diehards on either side of the debate. These documents illustrate fear as much as they do hope, and ideas about the future of empire that focus more on reworking colonial relationships than on recasting the terms of empire. In a sense, this chapter sets up a way of looking at the genealogy of these ideas, not among the top rank of thinkers or theoreticians but among administrators, academics and children. Recreating ideational contexts, alongside the research stories that form my own, allows for a constellation of micro-histories that relate to the broader historiographical discussion around historical contingency.

\section{The inside of pagodas: The Future of the French Union}

Back, then, to Paul Mus' book and my momentary unease at the discovery of its original marketing material. The unanswered question emblazoned on the cover contained within it the force of the expired contingency that inspired this chapter. Yet, in posing this question about the future of the empire, Mus was far from a marginalized voice. Although he had been born in Bourges, he was raised in Vietnam, attending school in Hanoi. Steeped in the fortunes of the French empire, he had taught Asian languages at the École française de l'Extrême-Orient, and served the Free French in Africa and Indochina. After the war he was the director of the prestigious École nationale de la France d'outre-mer (ENFOM) and professor at the Collège du France until 1950, when he resigned his ENFOM post in protest at French policy in Indochina to work at Yale University. ${ }^{16}$ The book itself was received well, and continues to be of use to academics. ${ }^{17}$ Indeed, contemporary reviews from figures such as Stanley Hoffman praised it over other works as the 'richest in substance 
and reflection' on the topic. ${ }^{18}$ Importantly, Mus' experience and personal history in the territory of French Indochina informed his reaction to its loss. He had been an influential figure in shaping the French Union project, and in 1944 had sought to persuade Henri Laurentie, the director of political affairs for the Ministry of Overseas France, to construct an engaged and participatory union: '[A]nother possibility for the idea of the French Union. ${ }^{19}$ The failures to realize this alternative vision formed part of his cumulative disaffection with the viability of the endeavour and the capability of France to realize these possibilities. His book is as pessimistic as it is outraged, and its colonial future is tainted by its proximity to this perceived calamity. Mus 'foresaw a future haunted by his historical present'. ${ }^{20}$

This book followed his more famous work, Viêt-Nam: sociologie d'une guerre, which had been published two years earlier. ${ }^{21}$ It represented an exasperation with the colonial project, following on the heels of the Indochinese War. ${ }^{22}$ Inside Le destin de l'Union française, however, there is some hope. Mus reads the conditional nature of France's imperial future, though it was diminished in the light of Dien Bien Phu. This loss is the event that stains his vision of the future, condemning the way that France had conducted her imperial policy, and confirming a narrative that had begun after France's own liberation led to the reassertion of colonial mastery in Indochina. As noted by Agathe Larcher-Goscha, 'The world had changed since the war, France had changed, and Indochina had

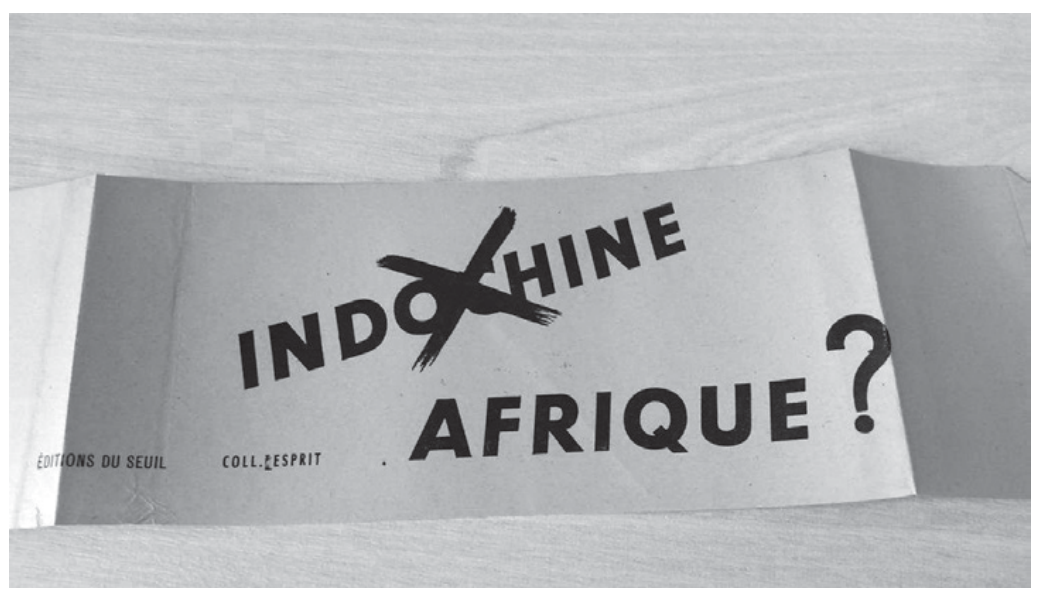

Figure 3 The original marketing material found inside Le destin de l'Union française 
changed, but the colonial relationship between Indochina and France remained the same, not in its administration but as an Ideal. ${ }^{23}$ Too much of the same old thing, from the same old mentality, Mus felt, would condemn France to losing her empire in its entirety. ${ }^{24}$ What was needed was flexibility, and a desire to engage with new options. He compared the formal French approach to more adaptive British policies:

We ought, I would say, to learn to love the exception, and not the one that proves the rule. Rather, the one that spills over the top, that invades, and swallows up every option but action. This attitude and stance is the part of the English naturalist. It is the counterpoint to the classicism on which we obsess, not least administratively but also constitutionally. Contrast the four little words that say it all, in the active social balance of the English language, 'it is not done', and that long word of ours, 'anti-constitutional.' ${ }^{25}$

Mus built this call for flexibility on his own cultural engagement with France's Asian colonies in particular, following a lifetime of academic work and lived experience. ${ }^{26}$ Emphasizing the influence of Mus' background on the writing of his contemporary history is not simply, as Richard Drayton observes, a mere epistemological game. Rather, 'it urges us to take stock of the foundations of our modes of historical subjectivity, and of the imagined human futures in which they are complicit'. ${ }^{27}$ Mus' pessimistic future reflected both his personal experience of loss and the broader climate of imperial uncertainty that haunted the late imperial state.

Mus' scepticism captured a growing trend of wary engagement with empire during this period. It was not the only frame through which the relationship could be understood or challenged, though. In 1956 the journalist Raymond Cartier publicly questioned the value of the French empire in the pages of the weekly journal Paris-Match. Cartier's articles provide an interesting insight into a current of opinion in the metropole. The three pieces, published on 11 and 18 August and 1 September, followed a visit by Cartier to West Africa. They contain three key messages within them: that overseas possessions were costing more than they contributed; that this was holding back France economically; and that this impediment could not be justified politically, as 'the emancipation of colonial people was unavoidable'. ${ }^{28}$ This stance has since been referred to as 'utilitarian anti-colonialism', and it spawned a contemporary movement, broadly known as Cartiérisme, that criticized colonial spending and instead advocated domestic 
investment. ${ }^{29}$ Why, he asked, is France wasting money on empire, when it could support more important causes closer to home? ${ }^{30}$ Yet, for those subject to the often cruel impositions of the colonial relationship, development might well be expected alongside the notional 'civilizing mission'. There is wrapped up in this debate a gap between rights, responsibility and agency.

Mus' book demonstrated that dissent was growing among commentators (even those once engaged in outlining the possibilities of colonial humanism), offering critiques of current policy and exhortations for reform. It denounced the complacency with which French administrators were allowing the empire to spin out of control. ${ }^{31}$ This cosy imperial consensus was also the one targeted by Cartier's articles. His refutation of the central logic behind imperialism, that it was politically and economically beneficial for the colonizer, offered a difficult prospect for contemporary media by challenging an accepted narrative. Cartier's view was rejected as, variously, 'the view from the Hexagon' and 'metropolism', stressing the insular nature of its perspective. Interestingly, it was also condemned as 'economically Maurassian', invoking the ultra-nationalist Charles Maurras, whose Action française had advocated an essentialist and exclusionary national identity that mingled with the fascistic currents of interwar Europe in an unpalatable way. ${ }^{32}$ Above all else, it callously used economic logic to cut through the social, cultural and political bonds that marked 'Greater France' as an overarching imperial entity. ${ }^{33}$ The curmudgeonly reaction from members of the press seems to indicate that they were as emotionally affronted as they were moved by Cartier's argumentation.

As one prominent British civil servant observed in 1967 after the end of empire: 'There was something inert about the white man's burden, and I don't think he expected it to get up and walk. ${ }^{34}$ This observation well describes the 'colonial common sense' that limited the French administration's willingness to endorse the agency of the colonized (or, at best, to endorse it with strict limitations) throughout the Fourth Republic. The milieu in which these administrative visions were formed affected the contingent limits governing their visions of the future. In the words of Frantz Fanon, 'The colonialists are incapable of grasping the motivations of the colonized. ${ }^{35}$ Paul Mus tapped into a sense of this judgement, citing a 'vicious circle' in which dehumanizing the subjects of empire led ineluctably to violence. ${ }^{36}$ Drawing on his own experience, Mus relates an illustrative anecdote: 'Few Europeans are really familiar with the inside of pagodas. ${ }^{37}$ When they are remarked upon, he says, people focus on the depictions of hell that they see painted on the internal walls. Yet, he 
warns, there is more to it. On the walls are traditionally depictions of the ten judges or kings who weigh souls after death, and send them to nirvana or to one of the many purgatories. The Western visitor, he points out, sees only hell, ignoring the tribunal, and the potential reward, as they lack the eyes to see them. ${ }^{38}$

Mus' work builds on his own imperial connections to counsel a more nuanced engagement with the concept of the French Union. This was, above all, an attempt to challenge the 'disconnect' of the French imperial mind, and an appeal to consider colonial subjects 'on the same level of humanity as the French'. ${ }^{39}$ He saw a future for the Union, but outside the formalism, inflexibility and violence he felt had characterized it to date, despite his attempts to counsel Henri Laurentie towards a reformed Union. Real reform, and not endless debates about the constitution, would offer something more tangible: 'A less legalistic and cramped definition of the French Union would better allow us to find a solution - or, dare one say it, perhaps to save it?' ${ }^{40}$ There was a marked difference between the abandonment called for by Cartier and the development advocated by Mus. The experiences of the long past clouded visions of the future, presenting stark moments of disjuncture. This disjuncture, in part, informed Cartier's jaded rejection of the value of imperial entanglement. His scaling of value is important, however: the value of development and the future, versus the value of self-interest and the present. Mus' valuation placed development and the future foremost, inspired by his own personal entanglement. At that moment in 1956, we can see the coexistence of multiple epochs during the same turbulent time, of distorted presents and emancipatory futures. ${ }^{41}$ Against this backdrop, disengagement with empire promised relief, but also abnegation of the future.

Mus continued to campaign for colonial humanism, even as France's policy continued to rehash the past errors it had committed. By ignoring the present, he felt, France was damning her future. In a letter to Le Monde in 1957 he extended this analysis:

Three years ago, when finishing a book on Le destin de l'Union française, I warned that we were, to my eyes, in the final moments when we could do something about it. Make no mistake on this point: we have not done it. We are now in the last hours where it is possible, by removing any qualifications, for us to introduce an alliance of equal peoples. ${ }^{42}$

He remained resolute in his commitment to a future that involved a peaceable settlement founded on ideas of sympathetic engagement. In 
this letter, he reaffirmed his sense of the present and of crisis, with France approaching a juncture. For Mus, this was something new, and particular to the present moment. He set this late colonial moment up as a sort of liminal space between the many wrongs of the colonial past and the uncertainty of an imminent future. In this same letter, Mus wrote: 'Two wars, a historic upheaval, and a new world outlook separate us from the recent past. ${ }^{43}$ The fallout of the Second World War and France's defeat in the Indochinese War increased tension and the sense of crisis. For Mus, this was a moment in which change needed to be actively defined. The French state, he felt, had to live in the present tense.

In Mus' flexible and empathic desire to recognize the agency of the colonized, we can see a very distinctive engagement with the future of the French Union. This gives us insight into the bonds formed in what Gary Wilder has termed the 'French imperial nation state', recognizing that the national republic could not be 'considered apart from the imperial nation'. ${ }^{44}$ Mus' personal loss is reflected in the broader loss of colonial society, and the severing of ties beneath the level of state (while acknowledging the inequality of these relationships). ${ }^{45}$ Through his work, we can access a personal sense of what would have happened, but for the inflexibility and unresponsiveness of the colonial administration. ${ }^{46}$ It seems apt that this was revealed through a very personal and contingent enquiry: cutting pages in a book and revealing old marketing material. These were tokens of a world in transition, and the question on the yellow half-sleeve was as much a marketing trick as it was a lament to the severing of Mus' own imperial bonds.

\section{A master and his dog: extracts from school homework}

I came across the second document in the Archives nationales d'outremer (ANOM), in Aix-en-Provence, during a course of research dedicated to the writing of an article on the loi cadre of $1956 .{ }^{47}$ The visit to ANOM was marked most memorably by meeting a group of elderly pieds noirs, the former settlers who had left Algeria following independence. I helped one of these men conduct some genealogical research, by helping him to use a computer in the catalogue room. He was looking for the birth certificate of his sister, who had been born in Constantine. He was, he claimed, too old to use computers. Delighted to be of assistance, I fell down a rabbit hole of research that was not my own, helping find relatives 
and reconstructing the legacy of a family who had been in Algeria since the nineteenth century. It went well and, as a result, I earned myself an invitation to lunch that day. This was an impressive affair, and much more than a meal for two. I had actually been invited to a friendly meetup of around eight pieds noirs, a veritable old boys' club. Presiding over festivities was a larger-than-life personality by the name of Guy - or, as his friends suggested I call him 'the Impresario of Aix. ${ }^{48}$

These self-described 'Algerian Europeans' formed part of the unanticipated exodus that surprised French authorities in the early 1960s. This tide of people was triggered by the end of French rule, provoking disbelief and denial "long after the movement had become a veritable groundswell'. ${ }^{49}$ For these men, in their lugubrious lunchtime reflections, Algeria had been lost, and its loss was definitive. That unexpected loss evoked a refusal to play any part in the future, or at least any future designed to develop an independent Algeria. As Shepard describes, the process of decolonization itself had led 'the unthinkable for most French intellectuals and politicians until the late 1950s, to become obvious to almost all in the early $1960 s^{\prime} .{ }^{50}$ Unearthing the roots of this pied noir family involved helping someone use archival technology to access documents produced in France relating to a historical narrative suffused with notes of loss and finality. These families, whatever their status or values, had been washed over by the tide of history.

The next day I returned to the archives to pursue my own research. I ordered a box with the reference ' 112 APOM.27', as it contained a ministerial report on 'Internal autonomy in the French Community' from 1958. This promised to give an official reflection on the late colonial state at the dawn of the Fifth Republic. The document that proved most interesting, however, was far less official, and, indeed, less circumspect. It was in its own sleeve, among a variety of documents that looked at the implementation of legal reform from the private archives of Louis Berthier, a longserving inspecteur des colonies (he had been appointed in 1942). The green folder bore no date, but simply the intriguing title 'EXTRAITS DE DEVOIRS SCOLAIRES' (extracts from school homework). It contained three typewritten pages, containing eight short extracts, from students ranging from fifteen to twenty-six. The responses are rich and interesting insights into the everyday understanding of colonial relationships. They also show how perspective altered visions of the future, and how unequal power relationships can be read from unusual sources. I photographed these documents in July 2008, though they were largely irrelevant to the project I was working on. They seemed important, however. For a long time the memory of these responses percolated, seeming to suggest some 
comparison with the lunch I had enjoyed with the 'Impresario of Aix' and his coterie of pieds noirs. Their memories, which were openly and joyfully shared, reflected a story of which I had been aware, of the lingering resentment of those forced to leave, their position on the political right and their hankering for a bygone era. Between the privileged voices of these men, and the subsumed voices of these school pupils, there was an important distance.

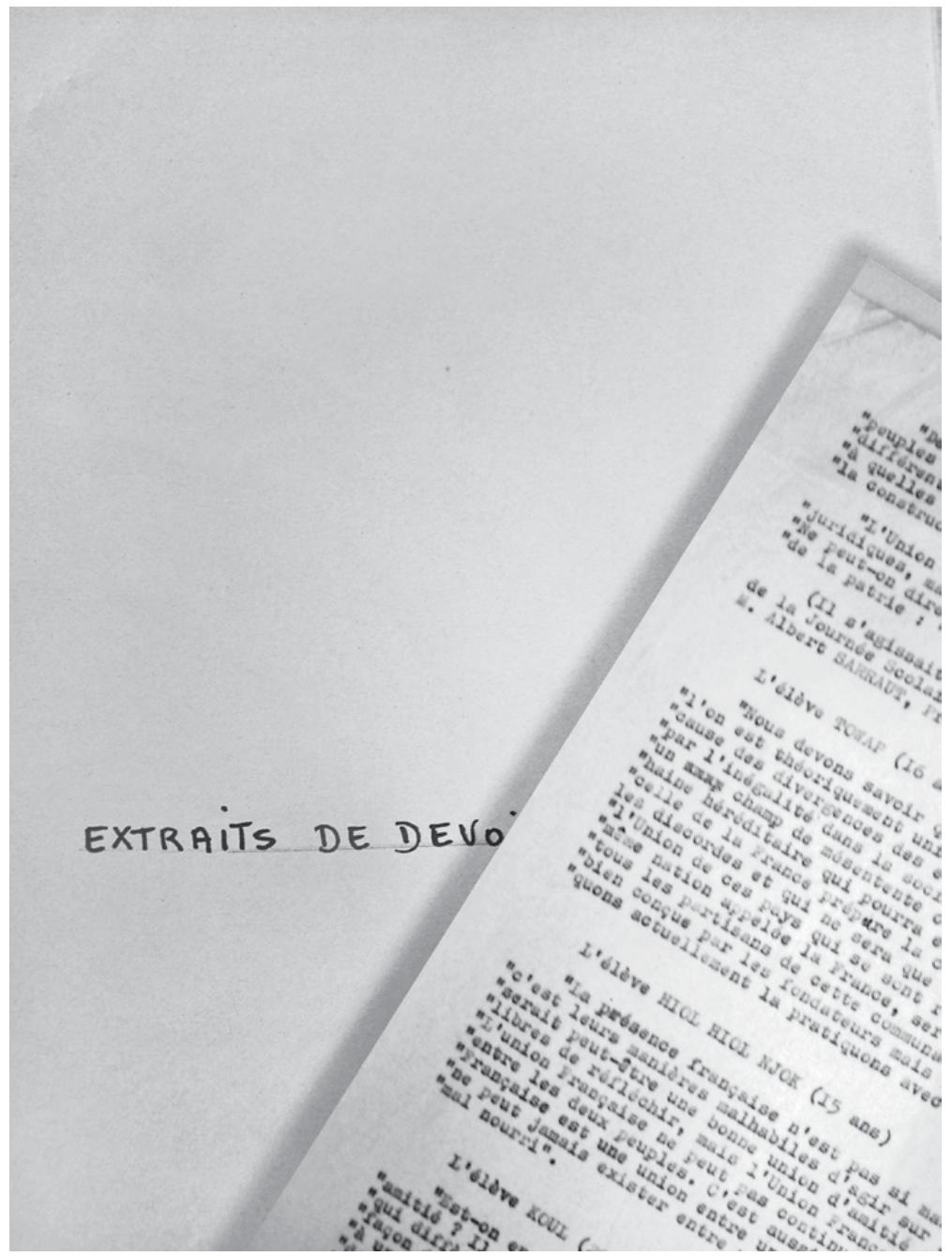

Figure 4 The first page of extracts in front of the green folder in the archives at Aix 
This homework was, in reality, submissions to the journée scolaire de l'Union française, a study day that sought to familiarize children in France and the colonies with the French Union, and France's ongoing development work. This was the brainchild of Albert Sarraut, an experienced politician (who had twice been prime minister in the Third Republic) and colonial reformer who had sought to ensure that France retained an interest in the colonies and remained committed to development. That he maintained a 'dream of colonial development' was evident in the interwar period, when he fought to 'sustain limited governmental, parliamentary, and public interest in colonial development'. ${ }^{51} \mathrm{He}$ published La mise en valeur des colonies françaises in 1923, calling for continued economic engagement with the colonies (a sort of opposite to Cartier's assessment). He viewed development as intrinsically bound to stable societies and the assumed goal of any civilizing mission. This task, he advised, involved the creation of the 'material well-being required for Western values to flourish'. ${ }^{52}$ Development could clash with the maintenance of peace in the minds of administrators, however, as can be seen in the French empire's schools, which maintained limiting curricula throughout the interwar period. After the Liberation, however, these schools became more open, and the values Sarraut promoted became central to their mission: 'The era of deliberate limits was over, but its educated products would be the major component of the first generation of African nationalists and government leaders. ${ }^{53}$ An interesting illustration of this importance can be seen in the fact that Paul Mus, the author of the first piece in this chapter, attended the Lycée Albert Sarraut in Hanoi, where he fostered his own imperial bonds. ${ }^{54}$ In this second document there is a sense of potential, of the importance of 'youth' to a durable colonial future. The belief was central to the orchestration of the journée scolaire in the first place. Yet, in these submerged voices, we also gain a sense of the blocked mobility of colonial youth, one of the precipitate conditions that imperilled the imperial status quo.

This post-war initiative was intended to continue that work, and Sarraut's position as president of 'l'Assemblée de l'Union française', until 1951, allowed him to establish a 'Prix de l'Union française', and later enabled the Assembly to develop the work by creating the study day. Established in 1955, the study day was held on the same day in both France and the colonies, usually in April, and promoted 'fraternal perspectives' between students. It promised a tempting reward that went beyond prestige: first prize took F50,000, second took F30,000 and third took F20,000. ${ }^{55}$ More than this, the winners (and those who were commended) could enjoy a 'colonie 
de vacances', ${ }^{56}$ spending a week in the south of France at Anglet-Biarritz. ${ }^{57}$ These opportunities for leisurely pursuit and scholastic recognition were valuable persuasive tools. Drawing young people into a system of reward engaged and encouraged them to become young foot soldiers of the concept of union. A trip to the Basque coast with a cohort of your peers, followed by a visit to Paris, offered an attractive lure for eager young minds. As such, the journée scolaire seemed an important and well-supported competition.

The prize was won in 1956 by Stelio Farandijs, a nineteen-yearold metropolitan student (of Greek parentage), who went on to have a glittering career as a champion of the concept of francophonie. ${ }^{58}$ In the 1980s Farandijs became secretary general of the Haut conseil de la francophonie, attached to the office of the French president. He became the perfect example of the competition's aims. Yet, clearly, not all respondents were young foot soldiers of the civilizing mission or francophile agenda. In the jaded climate of the late colonial state, the competition faced ridicule from both participants and observers. The Marxist journal La Pensée mocked the prompts with which schoolchildren were provided, under the headline 'No sign of the critical spirit!':

Each year, organised in France's educational institutes, there is a study day for the French Union. Here is the text from Marshal Lyautey which has been offered up for consideration by pupils of philosophy and elementary maths, just before the Easter holiday:

The successful man is always the one who holds an ideal, who loves action for the sake of action, who strives without cease, aims for the best, and puts in the effort, who doesn't spare the horses, and doesn't over-complicate things... Perhaps he'll die, but he will have lived!

To hell with reason! By inviting our school pupils to conflate a man of action and a dare-devil, university administrators are no doubt hoping to recruit the next generation of 'paras' to 'pacify' Algeria... ${ }^{59}$

Juxtaposing colonial violence with a fairly transparent attempt to avoid it showed up how little the competition could hope to achieve. This critical spirit was, perhaps, a cynical one, though the script provided by the competition organizers certainly seems a worrying way to live your life. This sort of prompt gives a useful indication of the sort of thing students were asked to engage with, though it also gives a good insight into the ways they could react against it. 
The responses included in the green folder can be dated contextually from neighbouring documents as having been for the competition in 1955 or 1956 . The prompt provided by the prize committee that year had asked students to consider the following:

The French Union is a constant creation that has its legal framework but depends more meaningfully on human connections. One can only speak of the French Union in the terms Michelet used to describe the Motherland: 'It is a grand friendship.' 60

The phrase 'constant creation' projects the colonial project into the future, casting it as an ongoing process that requires the active participation of its subjects. From the sampled extracts, the response of a fifteen-yearold pupil contains one of the most striking phrases. His name is given as Njok Hiol Hiol, and no other information is listed. We can discern from the distinctive name that the student was male and most probably from French Equatorial Africa (AEF). ${ }^{61}$ The only thing reported is an extract from his essay, which reads: 'The French Union is a union between a master and his dog, yet there can never be unity between a free man and a collared, ill-fed dog. ${ }^{62}$

Another response, from Nganso (nineteen years old), questions the sustainability of the French Union, offering insight into how the French defence of empire percolated into those territories perceived as peaceable:

The French Union has long been a constant creation, but since 1954, this French Union ceased to grow and has only shrunk. To tell the truth, there is a strong chance it will one day disappear altogether. It has not been long since Indochina went to war with France. One could ask why. The Algerians have risen and are also looking for their liberty. Monsieur Soustelle has seen the outcome of this rising and declared: 'If we leave Algeria, all of Africa is lost and France will cease to be a great power.' And can one really talk about the French Union in this day and age without talking about black Africa? If France loses Algeria, will the Paris-Brazzaville line be replaced by a Casablanca-Tunis line? And we should not forget that all the people of the French Union are waiting for their time to rise. In those circumstances, France may well shrink and cease to be a great power. It is an objective solution, my country need play no part in the French Union, nor in its particular problems, which seem to be in the process of being resolved anyway. ${ }^{63}$ 
Nganso's response echoes the historical writing of later years, offering a strikingly perspicacious account of the empire's ills. In particular, it sits well alongside this summary from Gary Wilder:

But by the 1950s, the French Union appeared to be an anachronistic and unrealistic attempt to retain an empire from which the Indochinese people had already separated and the Algerians were rejecting, Americans were undermining, and French capitalists were abandoning. ${ }^{64}$

These negative visions of the French Union seem to somewhat counter Sarraut's paternalistic vision of continued development as it was framed at the start of the 1950s. Here, we see more of the 'era of limits' that Peggy Sabatier ascribes to the interwar period. ${ }^{65}$ We also see a sense of frustration at work, a suggestion of the thesis that 'blocked mobility' promotes the emergence of nationalism. ${ }^{66}$ In the colonial sense, unequal relationships defined the French Union, despite the rhetoric, and this both characterized these responses and coloured their conditional view of the future. This, in turn, gave a sense of the Union as a 'frozen mosaic', which would limit the ambitions of Africans. ${ }^{67}$ Koul, a twenty-year-old student, wrote:

It seems less about friendship between countries, than about friendship between men. There are many examples that have shown the friendship of the French Union to be utopian. If it were a reality, what do we say to the movements of Indochina and Morocco, and to Algeria who follows the first two countries if not to independence then at least to their autonomy? It must be said that almost all the territories of the French Union want to follow this example [This last phrase is finely crossed out, but is perfectly legible]. ${ }^{68}$

Dismissing the promise of a utopian ideal, and predicting further instability, the elision at the end of this article is interesting. It would seem either that the courage to offer this criticism faltered, or that the half-hearted elision was itself a sort of challenge. There is a certain confidence both in the projections of these young men, who presaged colonialism's end, and in the aims of the competition's organizers, who hoped to inspire entrants to love the French Union. There is hope in the vision of the future described in Michelet's quote, and a disjuncture in the response of these few students. In the dwindling light of the late colonial state, it could be difficult to distinguish sparks from embers. 
For Elikia M'Bokolo, one of the key facets in the stability of AEF was the existence of an elite of petit-bourgeois African partners who had internalized the assimilationist ideology of French imperialism. ${ }^{69}$ Across the Federation, this class seemed neither capable nor desirous of formulating a coherent anti-colonial ideology. In AEF, there was a tiny minority of people who had experienced formal education, and this small elite tended to be close to the administration. ${ }^{70}$ As recently as 1955 the governor general of AEF, Paul Chauvet, ${ }^{71}$ had expanded the number of African teachers in the education sector in a programme designed to reintegrate returning graduates of metropolitan education back into the working life of the Federation. ${ }^{72}$ This sort of programme was intended, like the study day, to strengthen the connections between colony and metropole. Seeing this sort of criticism in the voices of these students is thus interesting for our understanding of the decolonization of AEF. These responses are a middle ground between anti-colonial nationalism and loyal collaboration. They were, after all, students being educated to a fairly high level, and atypical of many in francophone Africa, who lacked access to these resources. Likewise, they were participating in an international competition with a good degree of literacy and interesting critical ideas. Yet, in their rejection of the terms of the competition, they passed up the opportunity for a shot at its rewards.

In some ways, these respondents offered active resistance to the civilizing mission, rejecting its terms and refusing to be cowed. In others, though, they were simply cultural réfractaires, like those who evaded the Vichy government's forced work orders yet stopped short of armed resistance. ${ }^{73}$ The phrase crossed out in Koul's answer gives us some clue to this small act of rebellion, and the tenor of these young men gives us some insight into a quiet, growing frustration with imperialism. Differing perspectives inflected visions of the future. For French colonial officials committed to maintaining the bonds of this relationship, their imagined future entailed a new type of colonial attachment: more diffuse, perhaps, but bound by cultural entanglement. For those who felt that attachment like the leash on a 'starving dog', a little loosening of the collar was scant solace.

These responses give a real insight into the development of anticolonial ideas throughout the 1950s. In particular, the condemnation of these students helps to illuminate the way that popular opinion had moved beyond the control of colonial authorities, and the extent to which hopeful visions of the future were forced to confront increasingly negative realities. The potential of these young voices was frustrated, and chafed against optimistic imperial programmes designed to foster a sense of solidarity. These voices evoke a sense of future conflict due to lost opportunities. The loss described by the pieds noirs in Aix was 
definitive and retrospective. It noisily echoed tales about the fading of privilege, unlike the dissenting grumbles overheard in these snippets. The loss described in these extracts was one that did not fully envisage a future in which empire was categorically gone, yet they prefaced a turbulent future for the imperial status quo.

\section{On the spot: 'The political problems of French West Africa'}

The last document to be considered is a report written on 'The political problems of French West Africa' by the haut commissaire of French West Africa, Bernard Cornut-Gentille. The document itself was recommended during an anonymous review of the article that had sparked the archival trip to Aix en Provence mentioned in the last section. Yet it was accessed not through another archival search but through discussions and personal links. When looking for a copy, the only other reference that was obviously available was in the footnote of a piece by a prominent scholar on the subject. ${ }^{74}$ With a little trepidation, I contacted Professor Tony Chafer to ask if he knew where I could access a copy. As it turns out, he was the reviewer in question, and was happy to pass on a photocopy of the document that he himself had received from Joseph-Roger de Benoist, another prominent historian of West Africa.

The method by which the document arrived was fairly unusual, and, further, there is some ambiguity in the exact dating of this source. It can be deduced as arriving sometime between 1954 and 1955, before the announcement of the loi cadre, but after the battle of Dien Bien Phu. It is, then, strongly resonant of the difficulties described in the previous documents. Likewise, the method of its arrival charted connections in contemporary research, plotting out a logistical sense of an intellectual network. In this survey by a colonial official reporting to the civil servants of the Overseas Ministry, however, we can see another form of network at play, feeding back the analytical outcomes of colonial experience to the mechanisms of colonial control. The nature of this document's discovery reflects the para-political, often personalized nature of postcolonial Franco-African relations, and the system of administration that created it.

The document itself opens a vista on an older style of colonial administration as it came to an end. In its place, the development of new modes of imperial interaction threatened the basis of the colonial relationship. Between 1946 and 1954, according to Cornut-Gentille, West Africa had become the 'continent of fidelity'. ${ }^{75}$ Recognizing emergent 


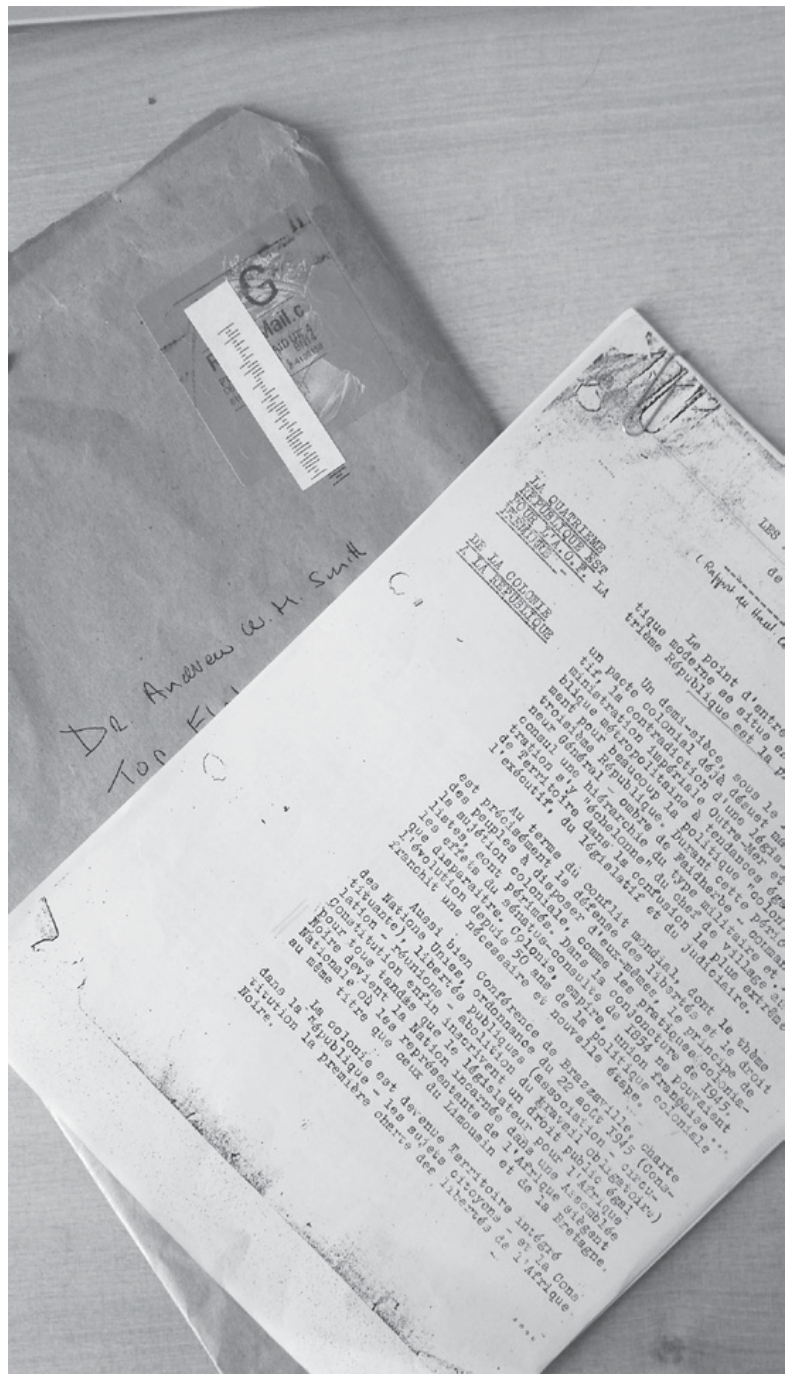

Figure 5 Cornut-Gentille's report

threats was a prudent attempt to manage that status and not a sudden inversion of old assumptions. Cornut-Gentille's report summed up well the task of reformers relying on an intricate knowledge of power structures and economic controls:

It is a fact that the French West Africa of 1954 appears to the casual observer as if it is an oasis in a world where many countries face a 
frenzy, and it is a fact that some 95\% of the Federation's elements are deeply committed to France.

However, it is a fact, too, that after seven years of living in Black Africa, I see, on the spot more than anyone else, the elements of concern that may trigger a more accelerated evolution than currently under way in French West Africa. ${ }^{76}$

The perspective of reformers who had experience of the territories clashed with an accepted narrative of colonial development being pursued in Paris. Just as the economic and cultural logic behind imperialism experienced challenges in the mid-1950s, so too did the political project of graduated autonomy that had been outlined at the Brazzaville Conference in 1944.

In France, the Fourth Republic offered a chance to renew engagement with the colonies, building upon a positive 'Brazzaville spirit" ${ }^{\text {'77 }}$ that followed the promises made by de Gaulle to France's African territories in 1944. These were promises made before France was itself liberated, offering an insight into the Republic that de Gaulle hoped to build. Yet there were important limits placed on the imagined future of colonial development:

The ends of the civilising mission accomplished in the colonies exclude any idea of autonomy, all possibility of evolution outside the French bloc; also excluded is the eventual establishment of self governments $[\mathrm{sic}]$ in the colonies, even in a distant future. ${ }^{78}$

This conditional view of the future established a firm contingent limit. Those limits were not simply practical, however, and they suffused the entire period of reform in the late colonial state. As Martin Thomas observes, 'Black Africans fixed on the hypocrisy of egalitarian promises that came hedged with colonialist presumptions about their limited capacity to run things themselves. ${ }^{79}$ Contingent limitations bred discontent and resentment, as expressed by the students mentioned earlier, and this eclipsed the reforming spirit of colonial administrators and postwar governments. Writing in 1956, the Marxist historian and renowned Africanist Thomas Hodgkin summarized the changing nature of colonial relationships for the European empires:

In our generation 'the colonial problem' means, principally, the problem of the relationship between Europe and its outpost communities in Africa, on the one hand, and the indigenous African 
societies on the other. Put crudely, it means: what adjustments, compromises, surrenders, must the European colonial powers and their settlers - make in face of claims of 'African nationalism'?

Hodgkin noted that African political institutions had to be understood and engaged with on their own terms, offering a sense that previous attempts to co-opt and countermand these institutions by the colonizer had failed to produce results. One feels Paul Mus would have applauded his willingness to learn.

Such an engagement can be seen in French colonial reform, notably the loi cadre of 1956, which sought to devolve power towards local assemblies, frustrating demands for equivalence. ${ }^{81}$ This built, in part, on the recommendations of the men on the spot who had witnessed the strains of existing colonial bonds. As Cornut-Gentille observed, the target was 'the new social strata that were developing, whose place was dependent on the future of the AOF [Afrique occidentale française] and therelationshipbetween Franceand Africa', ${ }^{82}$ AsFrederick Cooper outlines, the loi cadre rejected the policy of assimilation, dropping the emphasis on equality that had come from Brazzaville promises.$^{83}$ No more was the colonial state looking to build a separate but equal French Union; now the hope was to complicate and nuance those relationships in the hope of continuing entanglement. In this moment, Cornut-Gentille's report seems to enter into dialogue with the other documents, offering a connection built on differing perspectives. ${ }^{84}$ The dissenting students represented the figures most likely to be co-opted, and the clunkiness of the political measures designed to do this seemed to refer to the warnings of Paul Mus. Cornut-Gentille saw that future in the political institutions the French could create or foster, however, stating that 'the French are no longer an ethnic concept, they are a political concept' ${ }^{\prime}{ }^{85}$ This recognized a much more practical engagement, shorn of the idealism that had tended to mark visions of the future in the post-war world. As such, we can see this language prominently in the structures of colonial administration. In February 1957 a note prepared for the minister of overseas France, Gaston Defferre, by his ministry stated:

Whilst African and Malagasy deputies are largely men accustomed to the realities of power and prepared to accept the necessary compromises, African and Malagasy [popular] opinion is more sensitive than its elected representatives to absolutist ideologies and issues of passion. ${ }^{86}$ 
This report echoed Cornut-Gentille's thinking, especially on his return as minister of overseas France in June 1958. ${ }^{87}$ These echoes demonstrate a thread of institutional continuity, building on the accumulated knowledge of a ministry that relied on the first-hand experience of its administrators. The 1957 report proposed two solutions to this problem of public opinion: maintaining a strong line in debates, and attempting to support candidates for election in the territorial assemblies who accepted cooperation with France in order to give them the best chance possible. This mandated a strong information policy campaign of explaining the reforms, avoiding the 'real and serious threats' to the 'most reasonable parties and party leaders' ${ }^{88}$ Problematically, this seemed to echo Mus' political diagnosis, with instrumental engagement trumping any open offer of meaningful reform.

All this was undertaken with the intention of perpetuating a new vision of a colonial future, with a different, developed but durable relationship between the metropolitan centre and the colonial periphery. Far more than in any other economic or cultural arena, the management of political loyalties was undertaken with an eye on the possibility for contingent change. If the French Union was to be a 'constant creation', as proposed in the second document, then it fell to its administrators to guide that process. The worries expressed in the first document were that this guidance was lacking. Indeed, it does seem within Cornut-Gentille's report that there exists a certain anxiety founded on his perception of the colonial future. His nervous anticipation of contingent shocks moves his pen in the conclusion of the report, recognizing the cultural and political possibilities suffusing the senescent French empire:

This report, which is by necessity a synthesis, is therefore incomplete and inaccurate.

Incomplete because it insufficiently explores some questions and fails to mention certain others, whether through forgetfulness, or because they are secondary, or even because they do not need any new action.

Inexact because this depiction of the people and issues of the AOF tries to address change and not the problem of the present moment, never mind that of the future... ${ }^{89}$

These qualifications acknowledge the limits of Cornut-Gentille's ability to anticipate all potential outcomes. He was not an omniscient observer, and so this seems intuitive, yet, again, the need to articulate this in his report stresses a certain unease about the sense of what is to come. 
His report addresses the problems of the present moment, specifically indicating where they might impinge on future stability. His recommendations focus on ways to ameliorate the problems of today in service of a better imagined colonial future.

Cornut-Gentille's report gives us his own insight based on his experience. His reading of French West Africa's political problems is intricate, yet his willingness to endorse that vision is limited by his sense that events were accelerating. This was not just true for metropolitan colonial elites, however. Wilder quotes Léopold Senghor in a similar sense: '[T] govern is to anticipate [prévoir]..., to govern is to choose. In reality, choice is a function of anticipation [la prévision]. ${ }^{90}$ Senghor's pleas for a federal solution to the tensions that faced the unravelling of the French Union supposed that France's 'anticipation' was fundamentally based on a trust in the capacity of the French Republican system to weather these shocks. Yet, in Cornut-Gentille's report, there is a specific rejection of that ability to anticipate.

This document, received through an informal network in the contemporary context, illustrates the challenges facing the informal networks of empire. Cornut-Gentille was a 'man on the spot', making the choices that Senghor described. Yet his fear over his ability to inform these choices illustrates a changing appreciation of the agency of the colonized. Importantly, however, his recommendations do not settle on disengagement. ${ }^{91}$ He retained a belief in the lingering influence of the French colonial administration, and seems, in this, to foreshadow the lingering influence of informal networks typified by Jacques Foccart's African cell..$^{92}$ His conditional view of the colonial future outlines what he believed should occur, in the face of turbulence and reform, to best serve France's interests.

\section{Conclusions}

This chapter has explored contingencies and entanglements in the late colonial state, yet it has also offered some comment on contingencies and entanglements in the archive, interrogating our understanding of material and also our means of processing it. These colonial futures were anticipations of the journey ahead, and often saw adaptation and accommodation in the face of swirling possibility. Our ability to read this latent possibility with the same historical common sense is a difficult task of reconstruction. It cuts across archival collections, as it cuts across actors in the last days of empire. This point is reinforced by the flux of archival 
collections revealed at sites such as Hanslope Park and around issues such as torture in Algeria, and suggested by the ephemeral quality of contemporary digital archiving. ${ }^{93}$ The provenance of these documents, as highlighted in each of their research stories, itself raises questions about discovery and context. These challenging archival issues demonstrate that source bases in motion influence our point of observation.

Capturing the conditional in the late colonial state allows us to explore the assumptions and inferences that mapped out historical visions of the future. There was no static vision of what came after empire for France. Visions of the future were contextual and contingent, reflecting beliefs and assumptions about the agency and abilities of Africans and colonizers. Throughout the 1950s French officials planned for changes in the ways that they ran their colonial empires. The strains of the Second World War, increasingly assertive national movements and a changing international diplomatic climate all mandated a need to alter existing practices. Visions of the future could motivate nationalists to intensify their struggle when they saw their future at its most precarious. Worries about disorder could push the hand of colonial officials who sought to pacify dissent. From ordinary people to those statesmen and spokesmen at the very top, thoughts on how things would pan out could steer their minds and write their words.

These documents combine three personal perspectives on the future in the late colonial state, helping us to nuance an anti-teleological reading of the end of empire. They illuminate the ideational context in which questions about empire were framed, and help plot the historical constellations under which these actors laboured. They re-emphasize that behind every document is another person (or people), and that by sifting through a mountain of documents one is retreading the paths of the archive, and building on established narratives of the past. The first shows one man's personal connection to the empire and the loss of belief in the project that the changing relationship of the 1950s created. He offers visions of what would have happened, if only after the abandonment of the inflexible and unfeeling policies that led to the collapse of the colonial state in Indochina. The second shows the way in which submerged voices prefaced a sense of lost opportunity, especially when juxtaposed with loud voices mourning the losses of the past. This potential gives a sense of how empire could have developed, but for the unequal relationships that marred colonial education. The third lends insight into the 'man on the spot', his belief that the French could continue to control the situation, but his fears for the political problems that imperilled that influence. This, 
in turn, looks to what should have happened, offering its own excuses alongside the analysis. All three offer pessimistic views of the future, yet show variance in their rationale. None of these sources challenge our reading of the future of these colonies as independent nation states, yet all nuance our understanding of the context in which these debates took place. We gain a sense of how contingency governed and shaped visions of the future in the late colonial state, and how a sense of crisis crossed categories.

By combining these different aspects of the conditional, we can ourselves gain an insight into what might have happened, not in a counterfactual sense, but in the reconstruction of expired contingency. These points in the historical constellation of that moment were not fixed, nor permanent. Their visions were not simply carried along on the 'tide of history', nor buffeted loose by a 'wind of change', but were, rather, personal and insightful considerations of colonial futures based on personal situations and histories. The political and social climate that created the 'irresistible momentum' ${ }^{\prime 4}$ of decolonization was built on a dense network of contingent factors that promised an imperfect future. Reconstructing those conditional views and expired predictions is, in part, a work of reading along the archival grain and recognizing the contingency of our own enquiry that shapes our imperfect views of the past. Recognizing shapes in these historical constellations is not simply a work of confirmation but also one of discovery. 


\title{
5
}

\section{The dynamics of anti-apartheid: international solidarity, human rights and decolonization}

\author{
Robert Skinner
}

What might the activities of anti-apartheid activists in West Yorkshire tell us about the entangled histories of human rights and decolonization? Rights talk in places such as Huddersfield, far from the abuses of the apartheid system, was not the echo of a message transmitted from above, nor some revolutionary mantra taken up from below. Tracing the ways that these entangled histories were enacted by any number of grass-roots activists (in Britain, or, indeed, elsewhere), necessitates examination of how a flexible discourse of human rights took shape during a period of instability. Individual actors below the level of state spoke in concert with liberation movements fighting states, but in service of diverse aims. Rights talk in the era of national liberation was often contingent on sovereignty, and often became conflated with it as the message was taken up by broader - and transnational - activist networks. Looking at the evolution of these discussions allows us to understand how the turbulent context of the late 1950s and early 1960s shaped discussions of human rights well into the 1970s. In this reading, responsive and flexible definitions of human rights mapped onto a broader category of solidarity, which eclipsed an initial focus on individual political rights. This was a definition more contingent on the context of African decolonization than on the reality of newly sovereign African states.

To chart this mutable concept, this chapter first looks at the rights abuses in South Africa that triggered transnational protest movements and international grass-roots activism. This oppositional movement would help to define the language of human rights in apartheid South Africa against the language of decolonization as it took shape in the 
wider world. In part, this was a result of the networks it used to advance its cause. Petitioning the United Nations ensured that protests about South African rights abuses took on a colonial reference point. This was clear in the conflicting attitudes to violent struggle that separated movements with common cause; in the UN, postcolonial nations endorsed violent struggles to attain fundamental rights, while Western sympathizers often winced at the moral implications. Despite these differences of method, however, the discourse of rights was increasingly fixed to the discussion of nations and development. As postcolonial African nations began to speak of structural inequalities as ongoing forms of oppression, Western activists also took up an increasingly materialist language of rights. Yet, by the 1970s, this focus on structural reform and development was expressed in a way that distilled the legacy of the campaigns against racial violence and individual rights abuses that had taken place throughout the 1960s. By looking at transnational anti-apartheid activism and the interpretation of its legacy by distinct groups a decade later, we get a sense of how these debates had developed and been shaped by decolonization. The discourse on human rights, and its strong association with sovereignty and development, had been contingent both on the networks that made these calls and the forums in which they were heard.

Histories of decolonization tend to be, at the same time, histories of the triumph of the nation state. Even when recent scholarship has drawn attention to alternative possibilities, such as the federalist experiment in French West African territories in the aftermath of the Second World War, the narrative concludes with the ultimate succession of national sovereignty. ${ }^{1}$ Histories of human rights, meanwhile, have followed a similar orbit around the institutions of state and nation, tracing the emergence of a discourse of legal and moral entitlements that has become imbued with a disciplinary power over the actions of nation states. In some accounts, human rights are presented as a reflection of a cultural shift towards empathy and humanitarian universalism with its origins in late eighteenth-century Europe. ${ }^{2}$ More recently, human rights have been recast as a utopian vision emerging only in the 1970s, an entirely modern (or, indeed, postmodern) phenomenon. ${ }^{3}$ In this history, the 1960s has earned a poor reputation as a period in which, despite decolonization and an upsurge in radical idealism, the protection of individual rights and freedoms was locked in quiet retreat. Cold War calculations trumped universalist visions, and Soviet and US actions in Eastern Europe and South-East Asia overrode the high ideals of the late 1940s. Whatever student protestors, anti-Vietnam-War campaigners and anti-apartheid 
activists discovered in the 1960s, it was not a utopian vision of human rights. Until their 'breakthrough' in political discourse in the late 1970s, as Samuel Moyn has argued, human rights were weakly observed and little understood. ${ }^{4}$ This general observation - that, in international relations, human rights were largely defined in terms of, if not synonymous with, the narrower right of self-determination - might equally be applied to those groups and individuals in Britain expressing support for and solidarity with anti-colonial movements in the Third World. ${ }^{5}$ As Moyn's account implies, decolonization was a necessary precursor to the emergence of a human rights movement, as a new utopian vision that served as a response to the crisis of the postcolonial state. ${ }^{6}$

During the 1960s liberation movements saw the language of human rights as an appropriate medium for the articulation of struggles against regimes whose actions were in denial of emerging international norms of anti-racism, democracy and sovereign rights. The South African authorities provided a prime example of the deviation from these norms in their efforts to control political opposition by equipping themselves with an array of legal devices - banning orders, house arrests, extended powers to imprison suspects - that could be defined as threats to the fundamental rights of individuals. Although the articulation of rights language remained vague, functional and often subordinate to the primary aim of achieving 'liberation' and self-determination where it was denied, a coherent and coordinated articulation of human rights did, nonetheless, begin to take shape, partly in response to the ways in which the apartheid state demonstrated its readiness to abrogate individual rights. Antiapartheid activists deployed the language of human rights sporadically and instrumentally, but not purely as a synonym for sovereign rights. As postcolonial Third World states took up the language of human rights in the service of their own political agendas and to cultivate collective strength in global institutions, the meaning and form of 'rights' began to change. Western campaigners nonetheless sought to place individual rights at the centre of their conceptions of global political and social justice. This chapter explores these ways in which human rights, as a transnational discourse, reflected the entanglements of international institutions, state officials and social movements during the process of decolonization.

Histories of human rights and decolonization have tended, moreover, to limit their scope to discussions of rights talk within official circles. In the case of Britain, human rights have been seen as instrumental, deployed as protection against communism and totalitarianism, and intimately linked to the European Convention on Human Rights and its 
influence on key officials in the Colonial Office. ${ }^{7}$ The Bills of Rights introduced into the constitutions of former colonial territories were thus an attempt to tie postcolonial states into a transnational system of human rights. ${ }^{8}$ Roland Burke, in contrast, suggests that newly independent Third World states had indeed 'begun to transform the human rights project' themselves by the end of the 1960s; while the anti-colonial dimension of human rights history was by no means the ultimate expression of a utopian vision of rights, it nevertheless represented a reshaping of the agenda of human rights. ${ }^{9}$ Burke also demonstrates how the relationship between rights and self-determination was multi-stranded, suggesting, perhaps, that human rights might be presented as an assembly of contradictory and by no means consistent components - conceptual positions, expressed at critical moments within a particular set of institutions that came together in a formulation of 'rights'. Furthermore, he argues that Third World actors - even prior to formal decolonization - were often a driving force of human rights discourse not merely as a useful vehicle in the service of an anti-colonial agenda.

The idea that the struggles for independence in Asia and Africa were struggles for 'rights' was widely expressed, but invariably in ill-defined ways that tended to accord more closely with notions of natural rights defined by practice rather than pronouncement. Support for anti-colonial nationalism in the 1950s had tended to judge actions in the decolonizing world through the lens of the past. Rights could, in fact, be set within a civilizational discourse, albeit one that promoted the 'equal opportunity for all human beings to become civilized'. ${ }^{10}$ Protests against the South African policy of apartheid, for example, had employed the notion of 'human rights' from the late 1940s and early 1950s, but these tended to be declarative, serving more as an expression of the general moral impropriety of apartheid than a programme for the establishment of a universal rights regime. ${ }^{11}$ That notions of 'rights' were deployed in such a diffuse manner reinforces recent interpretations of the development of human rights in the post-war period that cast them as a loosely held utopian concept subservient to the more powerful idea of national sovereignty.

Instead, I would argue that post-war human rights discourses cannot easily be disentangled from the process of decolonization. Human rights in their narrower sense, conflated with the notion of self-determination, continued to maintain a moral efficacy for antiapartheid campaigners, but, with decolonization, the construction of an institutional structure around human rights - most particularly at the United Nations - provided a scaffolding that was both supportive 
of the struggle against apartheid and at the same time reflected its major concerns around justice, imprisonment and the rights of those engaged in armed struggle. The work of key UN bodies, including the Commission on Human Rights and the Special Committee on Apartheid, meant that human rights became firmly established as a central instrument against the apartheid state. Rather than seeing transnational activism and human rights as peripheral to the politics of the apartheid debate, this chapter suggests that human rights played a constitutive role in the dynamics of transnational anti-apartheid networks in the 1960s.

\section{International opposition to South African rights abuses}

South African race polices were a primary focus for debates around human rights in the late 1940s. They centred predominantly on complaints regarding the treatment of the Indian population, lodged by the government of India in 1946, as an international dimension of the endgame of empire in South Asia. Subsequently, human rights became a minor theme in the examination of the South African administration of the territory of South-West Africa (Namibia) by the UN Trusteeship Committee. ${ }^{12}$ In general, early international opposition to apartheid tended towards a diffuse moral condemnation of South Africa, until (at least) the mass arrests of South African anti-apartheid leaders in December 1956. The arrests and the subsequent Treason Trial, which eventually collapsed in 1961, accelerated the growth of international campaigns against apartheid, notably the International Defence and Aid Fund (IDAF), which went on to become one of the primary channels of financial assistance for South African liberation movements. ${ }^{13}$ The trial was also instrumental to the development of human rights movements in the United Kingdom, inspiring the formation of the campaign group Justice by a small group of British lawyers, whose members included the founder of Amnesty International, Peter Benenson. Another of its members, Gerald Gardiner QC, had been sponsored by Defence and Aid to observe the preliminary hearings of the Treason Trial in Johannesburg. In 1957 Justice was reconstituted as the British section of the International Commission of Jurists, and as such it drew back from active involvement in international campaigns but continued to 
work to position human rights on British domestic and colonial political agendas. ${ }^{14}$

The British anti-apartheid movement began to crystallize in the late 1950s, subject to the contingencies of decolonization and the Cold War. Anti-apartheid was defined not only as a negative campaign - against, and reactive to, apartheid - but also by a global politics marked by the ideological contest and very real existential threat associated with superpower tensions, as well as the nuanced differences between experiences of the end of empire across the world. Discussion of human rights tended to percolate into public debate only at moments of crisis, as in the wake of the Hola camp massacre in Kenya in 1959, or following the shooting of Pan-Africanist Congress supporters by the South African police at Sharpeville in March 1960. ${ }^{15}$ At these critical moments, the authoritarian impulse within the 'late colonial state' was revealed, pushing aside talk of 'development' and 'partnership' and underlining the moral case against colonialism. Human rights thus emerged as a point of reference in the politics of decolonization and the reframing of empire as Commonwealth.

Thus, in the wake of the shootings at Sharpeville, a cross-party group of British MPs drafted a petition calling for a Commonwealth convention on human rights. ${ }^{16}$ While, as Brian Simpson and Charles Parkinson have demonstrated, the Colonial Office had already begun to look more positively on constitutional bills of rights, the idea of a Commonwealth-wide convention seemed a wholly unwelcome proposition for government officials. Even within the Colonial Office it appears that there had been no conversion to the principle of legal protections for human rights; rather, it was recognition of their value in 'expediting Britain's withdrawal from her empire' that drove the shift in policy. ${ }^{17}$ For officials, then, the idea of human rights was instrumental for decolonization. In the eyes of the proponents of a Commonwealth convention, the suppression of political opposition in South Africa following Sharpeville was an ill omen for rights and liberties in a postcolonial world. But, in an unequivocal response, the British home secretary, R. A. Butler, argued simply that the viability of the Commonwealth was 'in great part due to the absence of this type of formal, institutional machinery'. He surmised that Commonwealth members would not welcome the imposition of 'rules of a central court or dictates of any convention'. ${ }^{18}$

The Sharpeville crisis precipitated a determined reassertion of authority by the South African prime minister, Hendrik Verwoerd, through both the suppression of the main black opposition movements and a consolidation of white support, embodied in the formation of a 
republic in early 1961. South Africa's exit from the Commonwealth later that year was a moment of triumph for Verwoerd, but one of despair for the British prime minister, Harold Macmillan, coming as a blow to his vision of a new Commonwealth. ${ }^{19}$ Ultimately, the South African policy of apartheid would provide a crucial point of reference in the development of a new, multi-racial conception of Commonwealth, not, however, one shaped by a formal conception of human rights. Butler's refusal to countenance a pan-Commonwealth convention defined the limits of official enthusiasm for transnational human rights frameworks in the early 1960s. While the practical benefits of human rights had begun to be recognized by senior civil servants, elected officials remained highly sceptical of any legally imposed definitions of rights.

The early 1960s did, however, witness the early growth of what would later be defined as 'grassroots human rights advocacy'. ${ }^{20}$ In particular, the launch of Amnesty International in 1961 saw the language of human rights deployed as a foundation for the depoliticized patronage of individual cases of injustice. The founders of the new movement were concerned with the sanctity of the activist as much as the salvation of the victim; Amnesty was a re-articulation of earlier forms of muscular Christianity as much as it was a new form of activism. ${ }^{21}$ Moreover, the Quaker and pacifist traditions that informed founders Peter Benenson and Eric Baker set Amnesty - in its early years - within liberal-humanitarian networks that had supported nascent anti-colonial and anti-apartheid campaigns in Britain. ${ }^{22}$ In 1963 Amnesty hosted a conference on the question of asylum in southern Africa, giving particular prominence to the 'increasingly threatened position' of the protectorates of Swaziland, Bechuanaland and Basutoland. ${ }^{23}$ Amnesty's intervention in discussions on colonialism in southern Africa is suggestive of the degree to which a discourse of human rights was shaped in the intersection between political and legal questions, between the regulation of movement across international borders and the political sensitivities that shaped the enforcement - or not - of these regulations. Shaped in the multiplicity of forces at play in decolonization and subject to the complex interactions associated with transnational activism, human rights became distilled into the narrower questions of legal rights, de-centring the issue of colonialism and sovereign rights. Moreover, the strong sense of moral propriety that shaped Amnesty's definition of 'prisoners of conscience' excluded the leaders of those African liberation movements that had embarked on armed struggle in the early 1960s. Thus Nelson Mandela, one of the principal architects of the turn by the African National Congress (ANC) to armed resistance, though unanimously accorded the status of prisoner of 
conscience following his arrest and imprisonment in 1962, was removed from the list as a consequence of his public assertions of the legitimacy of armed resistance against the apartheid state. ${ }^{24}$ Despite the ambivalence of Amnesty, the issue of South African political prisoners provided antiapartheid activists a conduit to connect a campaign for sovereign rights to international debates around the protection of human rights.

In late 1963 Mandela, alongside other leading members of the ANC/Communist Party armed group Umkhonto we Sizwe (MK), were tried for the capital crimes of sabotage and armed insurrection. On the eve of the trial, ANC leader-in-exile Oliver Tambo used an address to the Special Political Committee of the UN General Assembly to describe the actions of the South African government as 'genocide masquerading under the guise of a civilised dispensation of justice'. ${ }^{25}$ Two days later the General Assembly requested that South Africa 'grant unconditional release to all political prisoners. ${ }^{26}$ While Western states made little more than 'timid' approaches to South Africa, by the time the Rivonia defendants were sentenced to life imprisonment, in July 1964, their trial had served to energize transnational campaigns against apartheid. ${ }^{27}$ A key contribution to this came from the World Campaign for the Release of South African Political Prisoners (WCRSAPP), launched under the auspices of the Anti-Apartheid Movement (AAM) in November 1963. It was a coordinated international campaign, overseen by a small committee of MPs, anti-apartheid campaigners and South African exiles in London, and drawing on the support of groups from around the world. Eventually the WCRSAPP would submit a petition of nearly 200,000 signatures to the United Nations, while in Britain public attention was maintained through a series of vigils held outside South Africa House in London. It was in this matrix of state officials, non-governmental activists and exiled South African campaigners that human rights developed as an element of the discursive strategy of anti-apartheid. These networks intersected at different levels of national and international politics, with varying degrees of success.

The WCRSAPP had some influence through engagement with nongovernmental activists and organizations in Britain, and, as we shall see, was a point of entry for interaction with international institutions. Its impact on politics in South Africa itself was minimal, however. Although the worldwide campaign might be claimed to have had some influence on the decision not to impose the death penalty for the Rivonia defendants, the trial had dealt a severe blow to the effectiveness of the ANC as a liberation movement. ${ }^{28}$ Furthermore, less high-profile cases, such as that of Washington Bongco, who was executed in December 1964, 
despite providing momentum for the campaign, failed to attract international interest 'on the same scale' as the Rivonia Trial. ${ }^{29}$ Nevertheless, infringements upon the rights of political activists within South Africa continued to provide a critical point of reference for anti-apartheid campaigns. Even before the Rivonia Trial, international condemnation of the South African government's recourse to authoritarian measures had been heard. When the South African parliament approved detention of up to 90 days for individuals suspected of 'political' offences in April 1963, the International Commission of Jurists denounced the move as synonymous with Stalinism. ${ }^{30}$

Within South Africa, the most unswerving critics of the apartheid state's willingness to abrogate civil liberties and constitutional rights had been found within liberal opponents of the state, including the small Civil Rights League (formed in 1948), the National Union of South African Students and the Black Sash. ${ }^{31}$ During the 1960s experts examined the legal, psychological and moral consequences of the infringement of 'basic' and 'individual' rights enabled by legislation such as the 1963 General Law Amendment Act. ${ }^{32}$ These assessments tended, again, to define rights in their narrowest sense. Similarly, while it produced copious testimonies of the techniques of political suppression employed by the apartheid regime, including the use of torture on detainees, the WCRSAPP made little reference to the language of human rights in its publicity or private discussions before 1967.

Viewed in the context of the apartheid state, a coherent and consistent language of human rights had not emerged from a process of decolonization. Beyond South Africa, however, where colonial institutions had undergone transformation, new spaces opened up that had the potential to foster the elaboration of a discourse of universal rights. It was in the intersections between networks of anti-apartheid and rights activists, state institutions and international organizations, from the Commonwealth to the United Nations, that a language of human rights would be formed.

\section{International forums and colonial reference points}

During the 1960s the issue of apartheid became a unifying cause for Third World states whose leaders sought to hitch a language of human rights to their respective postcolonial priorities. Thus, the WCRSAPP highlights the ways in which the Anti-Apartheid Movement helped develop the institutional structures that incubated a discourse of rights 
in the service of Third World political identities. In February 1967 the WCRSAPP merged with a similar committee that had been established by the International Defence and Aid Fund in the previous year, and its frame of reference was widened to cover political prisoners across southern Africa. ${ }^{33}$ Under the sponsorship of IDAF, with the South African antiapartheid activist Dennis Brutus as the new director, human rights began to feature more prominently in its campaign rhetoric. This was, arguably, a function of its integration within networks associated with UN bodies, including the Commission on Human Rights. The UN Special Committee on Apartheid, which had first met in 1963, has been identified as a key site for the development of the instruments of human rights within the United Nations during the process of decolonization. As Roland Burke has shown in his detailed account, the efforts of representatives of Third World states in bodies such as the Special Committee revived the right of petition that allowed the United Nations to monitor human rights within individual states. ${ }^{34}$ The movements that had emerged in response to South African rights abuses were broadening their reach to campaign against rights abuses elsewhere. That these human rights discussions took place during the process of decolonization, as the late colonial state seemed to bow in the wind of change, inflected them with the language of sovereignty. The tenor of the discourse was contingent on its international context and its colonial reference points.

The international forums in which groups such as the WCRSAPP could operate saw their contributions shaped by the context of decolonization. The UN human rights seminar on apartheid, held in Brasília in 1966, provided one opportunity to exert international pressure on South Africa, and, together with the Special Committee, allowed groups such as the WCRSAPP to petition the world body. ${ }^{35}$ Although it allowed campaigners to mobilize a language of rights, however, the Brasília seminar demonstrated that groups continued to define rights in terms of sovereignty. The ANC, in its submission to the meeting, spoke of rights with reference to the UN Charter and its provisions against colonialism, and called for support for those 'fighting for transfer of power to the majority of the people'. ${ }^{36}$ While these accorded opposition groups the capacity to express their claims in an international forum, they would rarely elicit more than utterances of solidarity. The most concrete proposal to emerge from the Brasília seminar was for an International Day for the Elimination of Racial Discrimination, to be held on 21 March 1967, the anniversary of the Sharpeville shootings.

Similarly, rights talk played a muted and contingent role in discussions at the UN seminar on apartheid held at Kitwe, Zambia, in $1967 .{ }^{37}$ 
Nevertheless, the delegates at Kitwe did focus attention on issues that overlapped anti-apartheid and human rights concerns, notably the treatment of prisoners. By 1968 the UN Commission on Human Rights had established a working party to investigate the conditions of political prisoners. As such, the conduct of the apartheid regime was explicitly measured against key international human rights conventions, including the 1948 Universal Declaration, the International Covenant on Civil and Political Rights and the International Convention on the Elimination of All Forms of Racial Discrimination. ${ }^{38}$ The WCRSAPP became intimately connected to the networks and institutions that were tasked with carrying out this process, for example by supplying witnesses for the working party meeting in London in $1968 .{ }^{39}$ In the years following the Rivonia Trial, the fate of political prisoners became a core feature of the discourse of solidarity that characterized transnational anti-apartheid activism. Moreover, efforts to sustain public interest in the plight of the imprisoned leadership of South African liberation movements drew anti-apartheid campaigners into networks and institutions that - notwithstanding the limits of their sovereign power - provided a forum for the expression of a postcolonial language of human rights. Whether those institutions provided a viable basis for any progress towards national liberation in South Africa was another question entirely, however. In the aftermath of decolonization, apartheid became a fundamental concern of international organizations transformed by the participation of postcolonial nations, and, in the process, new visions of human rights would be advanced.

\section{What price human rights? Debates over violent struggle}

The twentieth anniversary of the Universal Declaration of Human Rights, in 1968, marked something of a low point in the hopes of those who had participated in the debates of the 1940s. The UN International Conference on Human Rights, marked by a series of attacks on Israel in the aftermath of the Six-Day War, was widely regarded as the nadir. ${ }^{40}$ The efforts to mark the anniversary bear further scrutiny, however, insofar as they demonstrate the entangled debates around human rights and struggles against white minority regimes in southern Africa. Following the General Assembly's decision to designate 1968 as International Year for Human Rights, the United Nations had called upon members to mark the twentieth anniversary of the Universal Declaration with intensified action on fundamental rights. States were urged to ratify 
key human rights agreements, including the International Convention on the Elimination of All Forms of Racial Discrimination, as well as the International Labour Organization conventions against discrimination in employment and equal pay for women. In Britain, plans for the Year for Human Rights were coordinated by a committee chaired initially by the former Archbishop of Cape Town, Joost de Blank, which instituted a subgroup tasked with exploring ways to assist the 'people of Britain's dependent territories to realise their human rights'. ${ }^{41}$

On one level, these discussions remained closely bound up with the language of sovereign rights and the anti-colonial struggle. At the same time, though, some began to move the debate onto new ground, seeking to bring human rights principles to bear on the matter of incipient armed insurgencies in southern Africa. During 1967 South African fighters had infiltrated Rhodesia alongside fighters from the Zimbabwe African People's Union, in search of a return route to South Africa. Operating independently in difficult terrain, the fighters were ultimately defeated after a series of clashes with the Rhodesian security forces. Although the mission ultimately failed, it demonstrated the capacity of MK fighters to engage in serious combat and marked a further escalation of insurrectionary violence across the settler colonies of southern African in the mid-1960s. ${ }^{42}$ While some contemporary observers regretted the apparent victory for the 'apostles of violence' within nationalist movements, serious discussion of the legitimacy of armed resistance to colonial rule began to suffuse public debate in the United Kingdom during Human Rights Year. ${ }^{43}$

It was here that the impact of the UN International Conference on Human Rights, held in Tehran in April and May 1968, was most strongly felt. The conference has been presented in recent accounts as a kind of farce, an opportunity exploited by its hosts to wrap their authoritarianism in the blanket of moral principles. Rather than promote the development of the human rights ideals first envisaged in 1948, the Tehran conference appeared to demonstrate that decolonization had resulted in the dominance of Afro-Asian blocs determined to promote visions of anti-colonial liberation over individual rights and freedoms. ${ }^{44}$ In advance of the meeting, Manouchehr Ganji, Special Rapporteur on apartheid to the Commission on Human Rights, had called for the United Nations to 'tirelessly reiterate its condemnation' of apartheid. ${ }^{45}$ The Tehran conference certainly fulfilled this aim. African states were particularly vigorous in their collective pursuit of a strong line on apartheid, eschewing compromise in favour of robust condemnation. ${ }^{46}$ South African race policy, the final statement declared, was a 'crime against humanity' because it 
represented an intense form of racial discrimination. The failure of South Africa, along with Portugal and the Rhodesian government, to respect the principles of self-determination was cast as a threat to international peace - a statement that would have seemed impossible to sustain only four years earlier. ${ }^{47}$ Here, the context of the campaign emboldened and inflected its language, ensuring that rights and sovereignty would mingle in the evolving discourse initially ranged at the abused rights of South African political prisoners.

If Tehran revealed - or, perhaps, underlined - the political expediencies that obstructed attempts to pursue human rights campaigns through the United Nations, the organization did provide an institutional framework within which NGOs could at least undertake transnational lobbying activities. Dennis Brutus, who attended Tehran as a representative of IDAF, reported that the conference had allowed him to establish contact with the governments that supported Defence and Aid (and provided a significant proportion of its income), but also to meet with NGOs to discuss the treatment of prisoners. ${ }^{48}$ It is, in fact, striking that the conference report payed close attention to the rights of those fighting against 'racist regimes' in southern Africa, recommending that all states 'take all possible steps to ensure that persons are not detained in prison for prolonged periods without charge', and noted that 'minority racist or colonial regimes' that 'frequently resort to executions and inhuman treatment of those who struggle against such regimes' should instead treat these individuals as political prisoners or prisoners of war. ${ }^{49}$ The IDAF (and WCRSAPP) were operating in networks that mingled rights talk with self-determination, against a backdrop of anti-colonial internationalism. In the late 1960s, though, this was conditioned by the context of violent confrontations between liberation movements and the lingering vestiges of settler colonialism.

It is significant that the language of human rights could be employed as a rationale for armed struggle, rather than being set in contrast to it. In September 1968 the Anti-Apartheid Movement held a conference on 'Human rights and the struggle against apartheid', chaired by the Liberal Party MP and AAM president David Steel, and also by John Ennals, chair of the AAM. ${ }^{50}$ The conference, whose speakers included ANC representatives Joe Matthews and Robert Resha, Guardian reporter Patrick Keatley and the anti-apartheid activist Ruth First, sought to demonstrate the extent of human rights abuses within South Africa, and thus show how African forces had been compelled to turn to violence in their efforts to obtain rights and freedom. These efforts do not appear to have achieved a great deal of success, and in the final months of Human Rights Year the AAM honorary secretary, Abdul Minty (who had also advocated on 
behalf of the WCRSAPP), used the Human Rights Year Committee bulletin to excoriate British failure to support freedom struggles in southern Africa. Individuals who had turned to armed struggle in their attempts to 'achieve their basic rights and dignity' were not, Minty argued, 'freaks, wedded to a philosophy of violence. ${ }^{51}$ For a member of a committee devoted to a year of educational programmes on human rights, Minty struck a pessimistic note, accepting that it was a 'major task' to inform people in the United Kingdom why African movements had resorted to armed resistance against white rule in southern Africa. For Third World leaders, notions of human rights seemed compatible with armed struggles undertaken in the just cause of liberation from colonialism; they seemed less so when viewed from the moral perspective of Western sympathizers. In the second half of the 1960s redefinitions of human rights were fostered by the advocacy of Third World states, and in particular by the impact of the ongoing crisis of colonialism in southern Africa.

\section{Individuals and (postcolonial) nations: development as human rights}

In his recent account of the international politics of anti-apartheid, Ryan Irwin has argued that human rights replaced nationalism as the 'thematic forefront' of debate in the late 1960s. ${ }^{52}$ As Burke has suggested, however, Tehran marked a shift from the standard of individual rights imagined in 1948 to one 'that emphasized economic development and the collective rights of the nation'. ${ }^{53}$ The late colonial context of rights talk was a contingent marker of its increasing conflation with sovereignty and colonial liberation. The flurry of efforts to build and sustain UN pressure on South Africa, Rhodesia and Portugal's colonial territories should be set within a wider narrative that describes an evolving human rights regime shaped by the increasing power of Third World nations in the General Assembly. As Burke demonstrates, the influence of the nonaligned bloc in the 1960s was hugely significant in the development of a human rights regime that could hold individual states to account. ${ }^{54}$ It was not the diminishing power of nationalism that marked anti-apartheid in the late 1960s but the burgeoning agency of the Third World nation state.

In 1966 the twenty-first session of the UN General Assembly had approved the International Covenant on Economic, Social and Cultural Rights. Dismissed as 'something of a curiosity' by some contemporary observers, Third World and Eastern bloc states welcomed it as a shift in the balance of human rights from individuals to nations. ${ }^{55}$ Together, the 
Covenant and the Tehran Conference define a moment at which postcolonial and non-aligned states had come to dominate the UN human rights agenda, while Western commentators remained squeamish about contemporary 'rights talk'. ${ }^{56}$ Some of the strongest advocates of this 'adjustment' of the principles of human rights were the heads of regimes that equated social and economic rights with the success of state-directed policies of development and modernization. ${ }^{57}$ In the late 1960 s it seemed that individualistic definitions of human rights were in abeyance, and political rights were deprecated in favour of a renewed focus on economic development. ${ }^{58}$ This shift of focus from personal, political rights and freedoms to social and economic rights distinguished the UN debates of 1968 from the discussions, over a decade earlier, at Bandung, where despite the efforts of Communist states - social and economic rights had been integrated alongside, rather than promoted above, more individualistic conceptions of freedom. ${ }^{59}$

By the late 1960s a distinctive Third World view, with an emphasis upon shared histories of colonization and attendant economic weakness, had come to mark debates around human rights. Western activists were, it seemed, prepared to adjust their own campaigns to suit the prevailing model of rights thinking, as shown when the IDAF and WCRSAPP engaged in UN forums. Indeed, the emphasis on social and economic rights seemed to present no barrier to those who had earlier argued that colonialism and apartheid were primarily repugnant due to their denial of individual rights. In February 1968 an editorial in Africa Digest noted the ongoing efforts to persuade governments to align their laws to the principles of the Universal Declaration, but acknowledged that very real economic and political constraints had made African states 'cautious in committing themselves on Human Rights' ${ }^{60}$ In particular, it noted that obligations towards refugees had been difficult to fully honour in the context of the population displacement that had resulted during the process of decolonization; indeed, by the mid-1970s Africa could be regarded as 'the continent of refugees' ${ }^{61}$ In this context, new definitions of human rights were beginning to emerge in postcolonial political discourse, shaped more by the contingencies associated with the process of decolonization than by any formal transfer of power.

But economic conditions could also become a point of reference for rights claims in themselves. Quoting from article 25 of the Universal Declaration, dealing with the 'right to a standard of living adequate for the health and well-being of himself and his family', the Africa digest editorial called for new thinking and 'greater generosity' in Western aid programmes. At a stroke, development could thus be cast as a human 
rights campaign, states could be conceived as rights-holders, and the responsibility for action returned to the former colonial power. This line of thought had precursors in the concerns over 'neocolonialism' that had emerged in Third World thinking at the end of the 1950s, and had been picked up by Western campaigners thereafter. In 1962 the antiapartheid activist Michael Scott had told the UN Special Commission on Colonialism that a peaceful transition to a postcolonial world was bound up with struggles against 'injustice and tyranny and unnecessary poverty and deprivation of rights. ${ }^{62}$ By the latter part of the 1960s, however, African officials, such as Ibrahima Boye, the Senegalese secretary of the UN Commission on Human Rights, were beginning to suggest that economic development was a more pressing issue for Africans than Western concepts of 'fundamental rights'. ${ }^{63}$

Away from global institutions, the focus on economic development fostered a new, materialist strand of Western humanitarian discourse with an emphasis on the capacity of Third World states to deliver economic and social progress, particularly in postcolonial Africa. Beyond the rights advocacy of the AAM, this represented a parallel but distinct grass-roots movement growing out of NGOs engaged specifically in issues of development. In January 1968 a group of individuals associated with organizations such as Oxfam and Christian Aid came together to articulate their sense of an emerging crisis in the so-called 'developing world', subsequently published as the 'Haslemere Declaration'. ${ }^{64}$ This group bridged the transition from rights as an individual issue (as represented by the WCRSAPP and AAM) to a focus on the nation as guarantor of rights, emerging from the postcolonial debates of the United Nations. On the surface, rights talk was absent from the Declaration: political and economic independence and self-determination were highlighted as intimately linked to the eradication of 'human suffering and deprivation', but no attempt was made to suggest that such suffering was a betrayal of any universal standards. ${ }^{65}$ Rather than viewing Third World poverty as a breach of rights in itself, the Haslemere Declaration saw impoverishment as a symptom of an exploitative system that threatened Western civilization: '[A] system that can no longer respond to the individual abroad will deny human rights to those at home. ${ }^{66}$

The Haslemere Declaration was intended to be a programme of practical measures to rebalance what its authors perceived to be the unequal and exploitative frameworks of international trade and economic relations. While it did not rely on references to fundamental and universal values or rights, it was evidently influenced by contemporary attempts to reframe the parameters of debate around development, trade and 
aid, such as the Algiers Charter of Economic Rights for the Third World, drafted at the first meeting of the Group of 77 ministers in October 1967, and the Arusha Declaration, announced by the Tanzanian president, Julius Nyerere, in February the same year. The Arusha Declaration was explicitly referenced by the Haslemere Group as something that should be supported by developed nations, which 'should welcome and sympathise with attempts to create societies different from their own'. ${ }^{67}$ As Moyn has noted, however, the Arusha Declaration, although cast within the moral framework of the Universal Declaration of Human Rights, made only minor reference to the 'dignity of the individual' and certainly did not position human rights as any kind of universal code regulating the behaviour of states. ${ }^{68}$ Nevertheless, the Haslemere Declaration signalled, as did the 1968 Africa Digest editorial, that formerly colonized nations might construe social and economic development as a right in itself.

Economic inequality could, moreover, be positioned as a continuing form of personal oppression that drew formerly colonized peoples, alongside subaltern and deprived groups elsewhere, into humanitarian discussions with a global focus. In March 1969 the Haslemere Group announced plans to hold a convention on Third World poverty at the Roundhouse in London, the spiritual home of 1960s radical intellectualism. The organizers of the 'Poverty is violence' conference invited speakers who they perceived to be 'representatives of the Third World', who included the Anglican bishop and anti-apartheid campaigner Trevor Huddleston, the Black Panther leader Bobby Seale and the Roman Catholic Archbishop of Olinda and Recife, Dom Hélder Câmara. It was the latter's contribution that was, perhaps, the most significant, in that it elaborated a cyclical relationship between the 'violence' of structural social and economic inequality, violent revolt on the part of the oppressed and violent authoritarian repression. ${ }^{69}$ Câmara, in his subsequent fulllength treatise on poverty and violence, acknowledged the difficulties faced when seeking to make connections between material structures and principles of rights: 'It is not done', he noted, 'to talk too much about justice, rights, structural changes. ${ }^{70}$ The extent to which Câmara and the Haslemere Group were consciously seeking to embed campaigns around material inequalities within a discourse of rights is not clear; this was, arguably, the language of what Michael Barnett has called 'alchemical humanitarianism', rather than human rights. ${ }^{71}$ But these interventions illustrate the extent to which the language of rights could be remoulded in the light of the unfinished business of decolonization, with an emphasis on the social and economic, in contrast to the fundamental political, and individual, aspects of the 1948 Universal Declaration. 
In the wake of the Roundhouse convention, AAM activist Robert Hutchinson proposed a 'Haslemere-style' campaign focused on southern Africa. He argued that 'British capitalism [was] buttressing the racist regimes of southern Africa and collaborating with those regimes to exploit and dehumanise the (mainly) African workers', and called for 'publicity and direct action' against the British businesses involved. ${ }^{72}$ Early in 1970 the Haslemere Group launched a targeted campaign against Barclays Bank, centred on the public condemnation of its investments and activities in South Africa. ${ }^{73}$ The Barclays protest campaign, with its emphasis on individual direct action, was timed to exploit the public interest that had been aroused by the distinctive 'Stop the seventy tour' campaign against sporting connections with South Africa - an action that has been seen as revitalizing the anti-apartheid movement in Britain, effectively exploiting the repertoire of 1960s radical politics in the cause of anti-racism and human rights. ${ }^{74}$ Human rights had long been equated with civil liberties in British political discourse, but the connection between civil rights and anti-racism suggests the domestication of central tenets of anti-colonial and anti-apartheid campaigns.

In a striking example of this impact, the Huddersfield 'Stop the seventy tour' campaigners announced in July 1970 that they would continue as a 'human rights' group, given the success of their campaign. They set up an anti-racist education campaign and provided practical advice on civil liberties issues, symbolically connecting the legacy of advocacy groups such as the WCRSAPP into the materialist discourse on human rights that had emerged in response to the ongoing decolonization process. ${ }^{75}$ While the experience of one regional group of activists cannot be considered generalizable, there is a sense in which this shift of emphasis was representative of the trajectory of human rights activism in Britain in the early 1970s. That human rights were equated with civil liberties reflected a long and continuing trend in British political discourse. The practical focus on anti-racism suggests a domestication of the central tenets of anti-colonial and antiapartheid campaigns, precipitating a shift of emphasis towards racial tension within postcolonial Britain. Looking at how campaigns about the Rivonia Trials, UN conferences on sovereignty and changing attitudes to humanitarianism among NGOs all percolated down to this group of anti-apartheid activists in West Yorkshire helps to draw out the entangled histories of human rights and decolonization. Human rights constitute a fluid and flexible discourse, continually subject to historical contingencies; during the 1960s the process of decolonization was a primary factor in shaping the definition of 'rights talk'. 


\section{Conclusions}

The process of decolonization was critical for the development of human rights in the post-war period. By the end of the 1960s freedom from colonialism was understood as a self-evident necessity, underpinned by the most fundamental 'right' of self-determination. The conflation of human rights and sovereignty by anti-colonial movements seemingly generated anxiety as much as hope, as the call to 'seek ye first the political kingdom' was gradually recognized as a slim guarantee of human rights in the broader sense. ${ }^{76}$ Nevertheless, the call for 'rights' in the anti-colonial movements of the 1960s became more than a straightforward exposition of the right to self-determination. The notion of human rights underwent a form of mitosis, with distinct and divergent discourses of Third World 'rights' emerging, including the strong (and troubling) sense that the postcolonial state could be conceptualized as a rights-holder. 'Grass-roots' forms of human rights advocacy, exemplified by movements such as Amnesty International, had focused on the rights of the individual, and legal protections of those rights, through asylum, freedom from arbitrary imprisonment and adherence to due legal process, but Third World governments began to claim the 'right' to social and economic development, reframing the development state as the primary agent of human rights. Western activists, nevertheless, continued to place the protection of the individual human at the centre of human rights discourse. It is significant that one key strand of Western anti-apartheid solidarity, embodied in IDAF, framed its campaign in support of South African liberation movements around concerns for the rights and well-being of individuals, and sustained its work through a network of anonymous mediators.

Decolonization also shaped the terrain upon which the concerns of Western anti-apartheid activists were played out, however. The unmaking of the colonial world meant that those networks and relationships that had fostered anti-colonial struggles for independence became transnational, both functionally and ideologically. In functional terms, supranational institutions such as the United Nations and the Organisation of African Unity provided transnational spaces in which anti-apartheid activism was enacted; in ideological terms, however, these same institutions, led by representatives of former African and Asian colonial territories, fostered the development of an instrumentalist view of human rights. During the 1960s apartheid emerged as a central focus of concern at key international forums (well beyond the dysfunctional debate in Tehran), in which anti-racism and human 
rights helped to stabilize 'decolonization at the international level'. ${ }^{77}$ For international anti-apartheid activists, 'solidarity', which had initially connoted a more straightforward advocacy of fundamental principles of sovereign rights, had come to be set within the framework of Cold War geopolitics and 'neocolonial' relations within the world economy. In this context, human rights - defined in terms of social and economic rights - became a way of framing debates around development and neocolonialism. The Haslemere Group thus exemplified early steps towards a critique of the structural inequalities of the decolonized world, and demonstrated how the debate had taken shape, from West Yorkshire to the 'Third World'.

Human rights, as an 'empty vessel' into which all manner of ideas and concepts could be poured, was an obvious choice of discursive framework for Western activists seeking to reconfigure their own agendas in the light of the transition to independence in Africa. At the same time, apartheid had become one of the primary issues around which human rights campaigns came to be defined. Human rights discourse was instrumental in shaping anti-apartheid activism in the 1960s, but, equally importantly, apartheid was a critical point of reference that shaped the parameters of human rights discourse at local and global levels. Above all, the unresolved question of apartheid served as a reminder that the process of decolonization was ambiguous and incomplete. Even when the nation state had emerged as the single possibility for postcolonial independence, decolonization continued to exist as a process of becoming, marked not by its possibilities but by its limitations. The ongoing existence of colonialism and apartheid in southern Africa was a constant reminder that Africans' experiences of independence were contingent upon their place in the world. Apartheid was both metaphor for, and lived experience of, African dependency. 
Section 3

Entanglement 



\title{
6
}

\section{'A worthwhile career for a man who is not entirely self-seeking': service, duty and the Colonial Service during decolonization}

\author{
Chris Jeppesen
}

Writing in 1955, Kenneth Bradley, a former district officer in Northern Rhodesia and then director of the Commonwealth Institute, ended the updated edition of his Colonial Service recruitment pamphlet, A career in the Oversea Civil Service, with these words:

If you agree with me that the Commonwealth and Empire are our proudest heritage, and that to serve the Colonial peoples is the greatest privilege and the finest opportunity for practical, constructive and selfless service to humanity which you are ever likely to be offered, then for you this may be only THE BEGINNING... ${ }^{1}$

In so doing, Bradley evoked the core quality of idealistic service, which for him stood at the heart of Colonial Service identity and mission. This updated version of the 'white man's burden', repackaged for a post-war audience, continued to draw upon many of the entrenched tropes within Colonial Service lore. Duty and sacrifice in the service of others had been proclaimed the driving force behind colonial careers since the late nineteenth century, and widely celebrated as such in popular depictions of empire throughout British culture. ${ }^{2}$ The image fostered of benign and beneficent colonial rule had always found enthusiastic support among the upper middle classes, who had dominated professional careers across empire since the late nineteenth century. ${ }^{3}$ Bradley hoped that by stressing the enduring importance of these qualities, even as the structures of the British empire fundamentally altered, he could inspire a new generation 
to take up this 'historic duty' and complete the vaunted journey towards colonial self-government in a multiracial Commonwealth.

This edition, revised from the original 1950 version, The Colonial Service as a career, did indeed highlight important changes in the ambition and character of colonial rule in the post-war empire. ${ }^{4}$ Gone were images celebrating the district officer (DO) as the embodiment of colonial authority, replaced instead with photos illustrating partnership and equality between British officials and indigenous people. In a tidy metaphor for broader changes, a chapter entitled 'Empire building' had been renamed 'Nation building', and it stressed that progress towards the Commonwealth was now the fundamental objective of colonial rule. While those who responded to Bradley's rallying call would find that 'the beginning' proved far nearer to the end than anyone suspected in the mid-1950s, it is clear from the testimonies of many Colonial Service recruits in the final years of empire that his words still resonated. ${ }^{5}$ In 1960 alone, the same year as Nigerian independence and a year before three more colonial territories followed suit, the Colonial Service made 816 new appointments to all departments across Africa, to add to the 18,000 colonial officials still serving in empire. ${ }^{6}$

Yet Bradley's pamphlet served a more instrumental purpose than a self-congratulatory celebration of selfless service and colonial progress. Despite the declarations of Colonial Office recruiters and retired grandees, colonial officers, unsurprisingly, were never motivated by altruistic sentiment alone. Throughout the Colonial Service's lifespan, the appeal of careers in empire rested upon a competing mix of utopian idealism and narcissistic egoism. Adventure, power, status and prospects were always as important to colonial careers as any impulse to service. ${ }^{7}$ Concerned at sharply falling application rates across the 1950s, the Colonial Office first approached Bradley to produce an 'inspirational' piece of propaganda to convince sixth formers and undergraduates that meaningful career opportunities were still on offer. ${ }^{8}$ Ultimately, his reassurances had little effect. By the end of the decade the Colonial Service could fill just over half the available positions each year. Once the career had forfeited its security, the Service laboured to sustain its recruitment cycle among its traditional audience. In spite of the not insignificant number of appointments, it appears that, for the majority of elite young Britons in the 1950s, empire became less important sentimentally precisely because it became less rewarding materially. ${ }^{9}$

It does not follow, however, that this group simply turned inwards as the empire started to be dismantled. Instead, they sought out new opportunities beyond the framework of the colonial state that would allow 
them to experience life in decolonizing territories. It is no coincidence that the end of a Colonial Service career coincided with the emergence of overseas voluntary organizations, nor that, as applications fell, the numbers employed in private commerce or development initiatives increased. At first glance, these appear to highlight a rupture in the dominant ideas of service and duty, with the old guard's outdated appeal marginalized in favour of a new 'modern humanitarianism'. ${ }^{10}$ Yet this perspective omits important strands of entanglement that ran between the colonial state and new forms of postcolonial overseas engagement. Even as many voluntary and development organizations very deliberately sought to distinguish themselves from the preceding colonial regime, they nonetheless approximated the vocabulary of service, and drew upon organizational associations that had been integral to a Colonial Service career. ${ }^{11}$ Opportunities that at first glance seem to have disappeared with the end of Colonial Service recruitment survived well into the postcolonial period, but came to be articulated in new and innovative terms to ensure relevance for a generation that did not hold Britain's colonial connection as timeless.

Until relatively recently, accounts of British decolonization have paid little attention to how the end of empire reconfigured metropolitan culture and, in turn, was itself shaped by currents of domestic change. On the one hand, while imperial historians have unpicked every minute detail of successive governments' colonial policy, only rarely have they situated the arena of high policy within a wider popular context. ${ }^{12}$ On the other, historians of post-1945 British history have been equally reluctant to incorporate wider global perspectives into their accounts of domestic social change. In explaining the profound transformations that followed the Second World War, accounts tend to emphasize the creation of the welfare state as the driving force behind the democratization and modernization of British society in the late twentieth century. When the empire does appear, it tends to be either as an anachronistic remnant of atrophying social hierarchies or else a costly burden that determined national decline. ${ }^{13}$

Efforts to move beyond these narrow parameters have delivered rich results. Since the 1980s the new imperial histories have escaped the realm of high policy to demonstrate how Britain's possession of a global empire profoundly reconfigured domestic culture and ideas of Britishness. ${ }^{14}$ By collapsing the entrenched binary of metropole and periphery to consider 'home' and 'away' as mutually constituted, this scholarship has charted how popular conceptions of race, gender, class and nation were transformed through encounters in empire and, in turn, 
shaped the relationships between local people and Britons living and working across imperial territories. ${ }^{15}$ Even so, until the last decade the principal focus of these studies tended to extend backwards from the early twentieth century, thus giving little account to the period of decolonization. Happily, this historiographical neglect has started to be redressed through a series of groundbreaking studies that bring together the histories of the post-war and postcolonial/imperial. ${ }^{16}$ This has allowed historians of post-1945 Britain to begin to map, in Jordanna Bailkin's elegant formulation, 'the afterlives of empire', revealing a complex mixture of continuities, dislocations and reconfigurations within decolonization's enduring imprint on metropolitan culture. ${ }^{17}$

The application of these approaches to studies of the Colonial Service has moved more slowly. During and beyond the lifespan of empire a wide literature has proliferated on its institutional frameworks, demographic profile and role in colonial administration; rarely does this corpus satisfactorily capture the Service's place within metropolitan culture during the period of decolonization, however. ${ }^{18}$ Recent analyses of the ideological and cultural dynamics of the imperial civil services have delivered enlivening results, but these tend to focus on the period before 1939. ${ }^{19}$ Long-established research traditions among scholars of African history have done much to reveal the limits of colonial authority in the field, the often insuperable gap between metropolitan expectations and local realities, and the racialized, gendered nature of colonial governance. ${ }^{20}$ Entirely understandably, however, the focus on African contexts means that it is not always immediately clear how such perspectives connect to changing conditions in Britain. Larry Butler and Sarah Stockwell's recent edited volume on Macmillan's 'wind of change speech' refreshingly demonstrates the possibilities for fresh insight offered by exploring more carefully the ideational relationship between high policy and popular reception, and metropolitan rhetoric and its reception in African territories. ${ }^{21}$

To borrow and adapt Martin Shipway's formulation, by triangulating our view of the Colonial Service during the period of late colonial shift to capture the relationship between official policy, attitudes among serving officers and the Service's position within wider British culture, we gain a more textured picture of the workings - and failings - of the late colonial state, as well as how decolonization impacted domestically. ${ }^{22}$ In so doing, the continuities and ruptures that emerged as British society adjusted to the loss of empire are brought into sharper relief. ${ }^{23}$ As Elizabeth Buettner has recently shown, the transformative effects of decolonization resonated as strongly and deeply in Britain as they did in 
newly independent African states. ${ }^{24}$ By considering post-war British history within a transnational framework, and the history of decolonization as an important element within post-1945 British history, we can better capture how the end of empire created new possibilities for Britons to engage with the wider world, just as it closed off others. ${ }^{25}$

To trace these ruptures and entanglements, this chapter examines the Colonial Service's 1950s recruitment crisis to explore why relatively few responded to Bradley's entreaties. It begins by focusing upon the role and ethos of the Colonial Service after 1945. Drawing upon previously underused recruitment literature, Colonial Office interview and training reports, as well as retrospective accounts written by former colonial officials, I explore how ideas of service and duty were understood within the Service. Until the end of recruitment these remained conditioned upon assumptions of class and gender, which determined who was deemed suitable to exercise authority during the late empire. What emerges are a series of contradictions that went to the heart of Colonial Service identity and that made a colonial career appear increasingly anachronistic in the context of late 1950s Britain.

Stepping back from the specifics of Colonial Service recruitment, the second half of the chapter situates a colonial career within the broader cultural landscape of 1950s Britain to examine how changing ideas of service and duty among Britain's social elite meant that fewer and fewer were convinced the empire offered a meaningful, or attractive, career option. The chapter concludes by briefly considering one alternative way in which young Britons embarked upon service overseas. Overseas voluntary organizations, principal among which was Voluntary Service Overseas (VSO), helped to fill the void left by the end of a Colonial Service career, but in so doing relied upon networks and institutional entanglements forged during the final decade of the colonial project.

\section{A gentlemanly service? The Colonial Service after 1945}

If the growing size of the Colonial Service is anything to judge by, even in the late 1950s few British officials had any inkling as to the strength of the wind about to blow through Africa. Throughout the twentieth century the Colonial Service remained the bureaucratic backbone of British colonial authority, and, as such, an integral part of the colonial state. ${ }^{26}$ In the aftermath of the Second World War it underwent unprecedented expansion in both size and ambition as the Colonial Office sought 
to realize its revised mission, announced in 1943 by the Conservative Secretary of State for the colonies, Oliver Stanley, to guide 'Colonial peoples along the road to self-government within the framework of the British Empire' through partnership, progress and development. ${ }^{27}$ This policy gained new scope, impetus and, most importantly, funding under the post-war Labour government. ${ }^{28}$ With the arrival of Arthur Creech Jones at the Colonial Office in 1946, the old orthodoxies of indirect rule and trusteeship stood ready to be swept aside through a vast, transformative developmental initiative. ${ }^{29}$

Characterized by John Lonsdale as 'the second colonial occupation', the Colonial Service expanded from some 7,000 European officers in 1936 (of a total cadre of 200,000) to 11,000 in 1947 (of 300,000) and to 18,000 in $1956 .{ }^{30}$ Across an increasingly diverse range of fields, the Service sought to harness technocratic expertise to facilitate the economic, material, political and civic development of colonial societies in preparation for self-government. ${ }^{31}$ Unsurprisingly, this change of emphasis was never intended as a purely altruistic act to precipitate the steady winding down of colonial power. ${ }^{32}$ Rather, colonial development offered a means to salvage the reputation of colonialism in the face of growing international criticism and Cold War pressure, as well as to boost Britain's stuttering economy in the aftermath of the war. Few policy-makers or officials saw a fundamental contradiction in these aims, confident that British expertise could bring material progress both at home and across empire.

Before 1939, and in the immediate aftermath of the war, Sir Ralph Furse dominated recruitment to all branches. He had worked in the Colonial Office since 1910 and served as director of recruitment from 1931 to 1948. After the First World War Furse's concern that the Colonial Service's reputation compared badly to the Indian Civil Service and Sudan Political Service drove him to raise its profile among the group whose applications he most coveted, the upper middle-class gentleman. To attract applicants, he relied upon a close network of public school and Oxbridge talent spotters to flag up likely candidates, followed by a personal interview at the Colonial Office. ${ }^{33}$ This ensured a large degree of homogeneity in the type of individual who applied, as well as offering Furse the opportunity to probe 'the imponderables of character'. ${ }^{34}$

Furse's ideal colonial official, and DO in particular, fitted a clear mould: educated at public school and Oxbridge, preferably with a family member who had served overseas, physically fit and good all-round 'officer material'. This ensured that the Colonial Service's institutional ethos aligned with the core values of the English gentleman: amateur, 
sporty, self-controlled and, broadly, conservative in outlook. To critics, this list translated as incompetent, unintelligent, sexually repressed and reactionary. Until the mid-1950s, though, the figure of the gentleman not only received wide public acclaim but was considered by many commentators to be the epitome of Englishness. ${ }^{35}$ Central to gentlemen's claim to constitute a natural ruling elite, at home and in empire, was a discourse of service and duty. Since the mid-nineteenth century this had oriented around the patriotic constellation of Crown, nation and empire.$^{36}$ Nebulous qualities of character and a spirit of fair play, learnt on the sports pitches of school and college, made the gentleman a dutiful defender of the underdog (or peasant African) but also imparted the moral courage required to ensure unflinching resolve in his duty to uphold British prestige. ${ }^{37}$ Of course, this ideal rarely translated into reality, but that should not detract from its influence on Furse's vision for the type of man he believed should stand as the bedrock of the British empire. ${ }^{38}$ Even among those who had not attended a public school, of whom there were more after 1945, this remained the proclaimed archetype towards which to aspire. ${ }^{39}$ Furse's vision found affirmation in print, and subsequently on screen, where the DO was typically conjured as bronzed, taciturn and morally steadfast. Clad in pristine white, khaki safari suit and pith helmet, to audiences across Britain these figures became the embodiment of British colonial power. ${ }^{40}$

Sabine Clarke has rightly observed that this stereotype's enduring traction has too often blinded historians to the growing diversity of the Colonial Service after $1945 .{ }^{41}$ In probing beneath the Colonial Service's much-proclaimed esprit de corps, Christopher Prior reveals a richer array of opinions and characters than the uniformity so celebrated in hindsight suggests. ${ }^{42}$ Rapid expansion after 1945 led to a greater mix of backgrounds among recruits. This was particularly true in the technical services, but also affected the profile of the Colonial Administrative Service (CAS). In contrast to the 1930s, when 77 per cent of recruits came from schools belonging to the Headmasters' Conference, between 1947 and 1956 this proportion dropped to 57 per cent. Among agricultural scholars, the split was almost equal. Although beyond the scope of this chapter, it is also important to stress the impact of the huge increase in the number of women appointed after 1945, an area that requires further attention. ${ }^{43}$

Change was slow, however. For much of the 1950s those in senior positions were members of the CAS appointed by Furse, who often found it difficult to reconcile their own experience in the colonies with the new expectations being articulated in London after the Second World War. This created a tension that went to the heart of the Colonial Service's 
identity: it could embrace the new technocratic agenda but, in so doing, diminish the role of the CAS; or it could resist London's modernizing proclamations, to reassert the traditional authority of the DO, who knew best his district and what his Africans most needed. ${ }^{44}$ The result was an unhappy compromise that satisfied few.

\section{Resistant modernizers: Colonial Service recruitment during the 1950 s}

As the 1950s progressed, the Colonial Office took care to present a modernizing and progressive empire, not as a crutch to fading British power but of service to humanity at large. Yet it still stressed a sense of duty and sacrifice, embedded in upper middle-class identity ${ }^{45}$ In preparation for a recruitment lecture at Cambridge in 1952 entitled 'The Colonial Service: my job', the organizer suggested: 'The general theme might well be: a life of difficulties, frequent disappointment and uphill work amidst environments which are often unfavourable, but offering a challenge which we, as a Nation, are called upon to meet, and a job which is infinitely worthwhile. ${ }^{46}$ Even more forthrightly, a 1955 recruitment poster pronounced it 'a worthwhile career for a man who is not entirely self-seeking. ${ }^{47}$ A declared commitment to the (exceedingly) steady progress towards a multiracial Commonwealth ensured that such pronouncements carried a distinctive inflection compared to those made a generation earlier.

Recruitment publicity echoed this point. Bradley was not alone in adopting typically Whiggish tones to remind potential applicants that they were just as beholden to ensure the successful transformation of empire into a multiracial Commonwealth as their predecessors had been to 'build' it in the first place. A 1956 report outlining how serving officers should approach recruitment lectures at schools stressed:

The vital point is that men are still wanted and there is a job to be done which is worth doing. There may be risks attached to it, and there are few jobs worth having which are entirely without risks, but there are opportunities also and above all the opportunity of assisting, not as some would have it, in the closing down of the colonies but in the development of the Commonwealth. ${ }^{48}$

The Colonial Office's message was clear: while the basic role of a colonial officer might be changing, this did not mean that the transition to selfgovernment should endanger long-term career prospects. 
Pre-deployment training was remodelled so as better to prepare officers for the challenges of managing a 'modern empire'. Lectures in economics, anthropology and history stressed that colonial peoples were not 'primitive' or 'backward' but 'underdeveloped' and that recruits' primary role would be to assist in the development of colonial societies. ${ }^{49}$ All officers, regardless of which branch they served in, were expected to bring expertise that would further this process and should expect to work alongside educated Africans in preparation for self-government. Contemporary and retrospective accounts testify that this message started to resonate among recruits. Although this was often conditioned on the assumption that self-government remained some years off - a sense always corroborated by senior officers - a growing number stressed their desire to undertake 'worthwhile service' in helping indigenous people to 'run their own affairs' or assist in the development of 'emergent nations'. ${ }^{50}$

Recruiters envisaged this spirit of friendship and progress forming the basis of relations between colonial officers and local people. After 1945 the Colonial Office showed itself well aware of the need to tackle the instinctive racism underpinning many of the axioms of trusteeship and indirect rule. ${ }^{51}$ Although this did nothing to curtail the racialized violence that often characterized the run-up to independence, nor challenge entrenched views among senior officers or white settler communities in Africa, it did lead to greater scrutiny of applicants' attitudes to race. Recruiters and training supervisors were quick to praise those recruits with 'progressive' attitudes. Many training reports recorded with satisfaction efforts by cadets to surmount racial divisions by cultivating friendships with African students or locally recruited cadets also on the course. These attitudes, recruiters believed, were vital to securing the bonds of intimacy required to bind the Commonwealth together in perpetuity.

Yet, even as public proclamations suggested a changing dynamic, entrenched attitudes among serving officers undermined efforts to connect with a younger generation. For all the talk of a new technocratic era, the Colonial Service never fully embraced the post-war agenda. Senior officers, almost all of whom had risen through the ranks of the district administration, remained loath to surrender the DO's pre-eminence in favour of a new technocratic elite, believing that technical expertise or knowledge of Africa still mattered less than character and conditioning. Recruiters consistently reaffirmed their enduring faith in the solid over the spectacular, championing the 'dependable', 'hard-working', 'wellmannered' and 'healthy' all-rounder. While many recruits gained praise for their willingness to engage with the abstract problems of colonial 
administration, this was always deemed a bonus rather than essential. 'Secretariat type' remained loaded with sneering inference, just as 'ideal bush officer' carried high praise.

Appearance, as a mark of underlying character, had always carried great weight in assessing applicants, and this continued into the 1960s. Officers were expected to be outgoing and sporty and to exert an air of effortless authority. Those who cultivated a less fastidious appearance or lacked the confidence and poise of the public school prefect or 'officer type' found it far harder to win the affirmation of recruiters. One undergraduate who enquired as to the possibility of applying was cryptically dismissed as "might be arty and "international"', another as '[p]olitically minded - doubtful'. ${ }^{52}$ This often went hand in hand with assumptions about class background and political inclination. One bearded grammar school recruit, who had also attended a redbrick university, was assessed by his interviewer:

I doubt... if he has been suitably realistic in considering whether the actual life and work is what would suit him; my feeling is that he may be rather given to facile enthusiasms rather than analysis and reflection... He is also a member of the United Nations Students Association and is very interested in work of this kind... I would like to have seen him without his beard but nevertheless he appears quite civilised. ${ }^{53}$

Interviewers often assumed that applicants from 'working-class backgrounds' would have a 'chip on their shoulder', or worried that they might be angry young men with subversive views on empire. If they were appointed, it was stressed that they should be sent to a strict district commissioner to be 'toughened up'.

Concerns over appearance acted as a proxy for deeper fears about whether those recruits who lacked the traditional conditioning would be able to cope with the realities of daily life as a DO or adapt to the social atmosphere of the colonies. In contrast, the 'right kind of background' frequently compensated for other deficiencies. Most sought after were those with family connections to overseas service. In recommending two candidates in 1950, the supervisor on the Cambridge training course, a former DO, observed: ' $\mathrm{X}$ has all the background of family service and the sincerity of thought that we could desire... What I liked especially about these two was the absence of materialism in their idea of the Service as a career. ${ }^{54}$ More importantly for many recruiters, these candidates were seen to bring a 'grounded and realistic' outlook to their job. These 
apprehensions linked inextricably to the growing political uncertainty surrounding the colonial project. Many senior officers continued to see the maintenance of law and order as taking priority over unduly hastening the process towards self-government through citizenship or mass education schemes, and that required tough, level-headed young men, not 'starry-eyed do-gooders'. ${ }^{55}$

Schoolmasters and college tutors remained well aware of these priorities. Echoing their interwar counterparts, referees highlighted outdoor interests, sports or an 'adventurous spirit', but moral leadership and honesty still counted for most. ${ }^{56}$ Indicative of the general tone is one college tutor's reference for a public-school- and Cambridge-educated applicant in 1960:

$[\mathrm{H}] \mathrm{e}$ is not by any means brilliant academically. But on the other hand, he is a very charming man, full of the social graces and with a great mass of common sense. He is possibly the sort of man who can be described as 'the salt of the earth'... I think that he is the sort of man who, while not brilliant, would make a very steady and reliable administrator. He is scrupulously honest, kind and humble, and I take pleasure in recommending him for an appointment. ${ }^{57}$

While direct reference to an applicant's 'gentlemanly credentials' gradually faded away, thinly veiled class inferences bubbled between the lines. 'Salt of the earth' evoked a modern gentleman of the meritocratic age, able to operate among all types of people but still defined by incontrovertible virtues of honesty, common sense and self-restraint. ${ }^{58}$

By tracing the efforts to attract new recruits during the post-war period we can begin to map the gap between the Colonial Service's rhetorical positioning and what this meant in practice. Attempts to explain the Service's role at the end of empire to a domestic audience exposed contradictions that went to the heart of the late colonial state. While a new inflection emphasized Commonwealth over empire, this endorsement was never unconditional. Misgivings over the pace of change reflected senior officers' resentment at having 'their service' overhauled by London bureaucrats. In this respect, the idea of 'duty' at the end of empire still accentuated patriotic and institutional obligations over the broader humanitarian emphasis that was starting to be heard more regularly across wider British culture. Recruits had to understand that their role was to maintain order and implement the decisions of their senior officers, not to set off on a reforming crusade. ${ }^{59}$ As had always been the case, the call to 'service' remained demarcated by carefully bounded 
limits. Many recruits chafed against these restrictions, but in the increasingly turbulent atmosphere of late empire senior officers would not compromise hard-headed realism for idealistic sentiment.

\section{Still a job to be done? Service, duty and British culture during decolonization}

If the recourse to a 'gentlemanly code' had been intended to assuage fears among a traditional audience, it largely failed. Nor did it resonate loudly enough with the new meritocratic elite reaching adulthood in the era of universal secondary education and the welfare state. Frustratingly, records of rejected applicants no longer survive. Nor is it possible to establish with any clarity why an individual chose not to apply. Nonetheless, from the extant records, it seems clear that the Colonial Service's institutional ethos not only determined the type of individual appointed but, just as significantly, heavily influenced who applied in the first place. As in many other areas of British culture after 1945, ideas of service, duty and character took on a more democratic inflection, becoming less associated with noblesse oblige and more with service to humanity at large. ${ }^{60}$ For those considering their career options in the late 1950s, empire could still represent an exciting, exotic and idealistic outlet for ambitions that could not be realized in the restrictive climate of home. ${ }^{61}$ Even as the Colonial Office persisted with long-established recruitment strategies, appealing to their traditional audience, many individuals sought a colonial career for reasons far more nuanced than a straightforward commitment to Britain's ongoing colonial status. When imagining the future career possibilities available in empire, many accepted that fundamental change was coming but also that the chance to play a part in that process, whatever it might involve, was a risk worth taking.

Colonial Office efforts were stepped up to reassure an increasingly sceptical audience of undergraduates, parents, school and university authorities alike that long-term, attractive career opportunities remained on offer ${ }^{62} \mathrm{H}$. H. McCleery, supervisor on the Cambridge Colonial Service training course, noted that fears over job security held heavy sway over potential undergraduate applicants: 'My experience has been that they are chiefly afraid of the political uncertainty. A man may have a keen sense of mission, and yet shrink from committing himself to a job which may turn bad on him while he is still in the early 30s... ${ }^{63}$ Even at the very end of the decade, interviewers promised at least ten to fifteen 
years' service. While several recruits remember these assurances sounding unrealistically optimistic at the time, they remained in line with government timetables for withdrawal from East Africa by the mid-1970s. ${ }^{64}$ Revealingly, the word 'career' was not removed from publicity posters until 1959, only three years before recruitment stopped, and even then the move sparked an angry response from senior officers fearful of the effect on applicants. ${ }^{65}$

Nevertheless, despite these efforts, recruitment rates continued to decline. The Colonial Service's dependence upon networks rooted in a narrow social clique meant that peer and personal affirmation was frequently crucial in directing individuals towards an application. Once parents, teachers and college tutors sensed a decline in career opportunities, or serving officers fed back negative criticism, the entire recruitment structure began to crumble. Similar problems had paralysed Indian Civil Service recruitment in the 1920s. ${ }^{66}$ By the mid-1950s morale among serving officers was in sharp decline, leading to growing numbers of resignations and frustrated letters to British newspapers. Perhaps most damagingly, serving officers increasingly warned potential applicants, including their own children, not to apply. ${ }^{67}$ Recruitment talks at universities drew ever smaller audiences, and even then a significant proportion attended in order to heckle over oppressive policies in Africa. ${ }^{68}$ The university appointments boards confirmed mounting undergraduate reluctance to apply, and by the end of the decade declared themselves no longer prepared to promote the Colonial Service. ${ }^{69}$

Elite career patterns did undergo a noteworthy shift during the 1950s. Full employment, and the gradual phasing out of national service after 1957, allowed for a more relaxed attitude towards finding a career. ${ }^{70}$ Traditional service careers became less popular, with fewer entering the armed forces, clergy or civil services, while the number joining business or engineering firms grew significantly. ${ }^{71}$ Opportunities to fulfil such roles overseas proliferated, often promising better terms of service than those offered by the Colonial Service. ${ }^{72}$ Contract terms gave individuals welcome flexibility while allowing them to accrue experience that would only increase future employability. In contrast, many young colonial officers who joined the Service in the early 1950s with the expectation of a full career increasingly feared that their experience in empire would leave them poorly placed to find new employment in Britain only a decade later. ${ }^{73}$

In the post-war climate, professional competence and technocratic expertise became the maxims of the new meritocracy; ability rather than conditioning would determine individual opportunity. ${ }^{74}$ 
Following the expansion of the grammar schools under the 1944 Education Act, by the mid-1950s a growing number from outside the upper middle class proceeded to higher education. ${ }^{75}$ Often labelled 'angry young men' by those such as Colonial Service interviewers, this group built a mounting critique of the gentlemanly ruling elite in the early 1950s, which erupted into visceral hostility following the Suez Crisis. Voices from across the political spectrum lambasted and lampooned the gentlemanly creed as antediluvian and anachronistic, without relevance to modern British life. ${ }^{76}$ The empire caste drew particular ire in these attacks, further fuelled by the series of 'colonial scandals' that broke in the late 1950s. ${ }^{77}$ Certainly, some grammar school recruits found the Service's institutional ethos infuriating. For Elwyn Thomas, agricultural officer turned novelist, the whole service could be scathingly dismissed as 'middle class from top to bottom, an outlet for the minor public schoolman, with his home in the suburbs the parson's son, the axed army officer's, using it as a ladder to improve himself socially, with its artificial air of gracious living and its milkround of orders and decorations. And how they love it!'78 Nonetheless, it is important not to exaggerate a sense of rupture. ${ }^{79}$ As the changing profile of Colonial Service recruits after 1945 highlights, a significant number of grammar-school-educated and redbrick graduates gained appointments and went on to build successful careers across all colonial territories. Problematically, however, they never applied in sufficient numbers to satisfy demand, while at the same time public school applicants also started to dwindle. ${ }^{80}$

Far from being unresponsive to the destabilizing climate of decolonization, the public schools' ethos during the 1950s and 1960s reflected a carefully crafted compromise. Contrary to the picture of moribund inertia that characterizes many depictions after 1945, they successfully met the dual challenges posed by the breakdown of empire and rising social mobility. By the late 1950s the most forward-thinking (and financially secure) institutions acknowledged that, to retain significance in the changing educational landscape, they had to reappraise core elements of their ethos. ${ }^{81}$ As they became less preoccupied with their role as nurseries of empire, so they placed less emphasis on a gentlemanly code of character, sport and manners. ${ }^{82}$ The focus fell instead on the need to retool elite young men to withstand emerging challenges at home, while seizing new overseas opportunities beyond the limits of empire. This did not entail the abandonment of their traditional values but, rather, their evolution to ensure relevance for a generation that did not take imperial status for granted and appeared intent on questioning the orthodoxies of their parents. ${ }^{83}$ 
Imperial achievements remained enshrined within the fabric of school buildings and traditions while leadership and character were preserved as core qualities, and it remained expected that ambition should lead public school boys to positions of power and influence. Yet little overt mention of colonial affairs appeared in the day-to-day culture of the schools, while an ambivalent shrug rather than any great outcry greeted decolonization. Time-honoured summons to imperial duty were dismissed with growing irreverence; The Monmouthian reported facetiously, in 1954, that one Colonial Service recruit was currently undergoing training 'to be a better bearer of the white man's burden'. ${ }^{84}$ Debates on imperial controversies barely surfaced but, when they did, tended to endorse moves towards a Commonwealth of nations. ${ }^{85}$ School magazines reported virtually nothing on colonial crises, while reports from old boys living overseas became an increasing rarity. Although the Colonial Office remained committed to sending the occasional speaker to talk on Colonial Service careers, so did many other organizations looking to attract public school recruits. School culture never lost its tone of reactionary, nostalgic conservatism, but when pupils became animated their focus was invariably domestic. Censorship, university access, sexual morals, the position of the public schools in the education system or class more generally all received and provoked far greater interest than the end of empire. ${ }^{86}$

Headmasters sought to prepare young men for a post-imperial future with greater competition from across society. Boys were still wholeheartedly encouraged to retain broad horizons and to view the world as an open field of opportunity; the end of empire did not mean that Britain's global role was over, and certainly should not, as one headmaster warned, predicate a retreat into a parochial 'tending of his own back garden'. ${ }^{87}$ Yet the fact that these would not be within the nexus of empire was not something to be lamented. ${ }^{88}$ Luminaries at speech days acknowledged that the empire project was changing but saw this as something to celebrate. This did not mean a cleavage with older traditions but, rather, their natural evolution into future triumphs. Returning to his old school, Haileybury, in 1957, Clement Attlee, Labour prime minister from 1945 to 1951, was careful to make this point:

The old imperialism which flourished when I was here has changed its character and now we have a great Commonwealth of Nations and I believe that the old Haileyburians of the East India College would have seen that as the fruition and not the frustration of its work. But it certainly does not mean that there is no need now for people to go out to the ends of the earth. There is that need. It is 
just as great as ever, although sometimes the work to be done is on rather a different plane - not so much ordering people about as co-operating - and I believe we shall still find Old-Haileyburians all over the world. ${ }^{89}$

The message was clear. For a new generation of elite schoolboys, just as eager as their predecessors had been to experience and exploit opportunities across the globe, the end of empire did not have to necessitate the abandonment of personal ambition. Rather, it merely required an adjustment of attitude and new emphasis on humanity rather than empire. ${ }^{90}$

\section{VSO: from ageing service to young man's challenge}

The Colonial Office never wavered in its promise of a career offering enterprising young people variety, a sense of service and adventure. These attractions did not evaporate upon the climax of empire, nor did schools cease to produce the type of character who had formed the mainstay of recruits throughout the twentieth century. So, what openings emerged to replace the void left by the disappearance of a career in empire? The late 1950s saw a blossoming of a student volunteer movement, which included growing numbers volunteering overseas. ${ }^{91}$ While this reflected a wider global trend, the origins of Britain's largest overseas volunteer organization, VSO, demonstrated especially close links to the late colonial state. ${ }^{92}$ This is not to suggest that volunteer schemes were based upon a desire to perpetuate colonialism, though some levelled these criticisms at the time. Nonetheless, as Jordanna Bailkin's recent portrait of VSO deftly sketches, its founding ideology drew upon long-established themes within the Colonial Service's recruitment message but sought to reconfigure these in order to energize a new generation of Britons to undertake service overseas. ${ }^{93}$ It is within this process of evolution and realignment - of which VSO offers one glimpse - that we can start to explore the entanglements that shaped the cultural landscape of decolonization. ${ }^{94}$

Voluntary Service Overseas was founded in 1958. The creation of former Colonial Service official Alec Dickson, it was intended to provide elite school leavers with the opportunity to undertake a year's voluntary work overseas before they started university. He feared that the vacuum left by the end of national service and the growth of the welfare state would inhibit young people's development into responsible citizens by 
closing off opportunities to undertake service for others or to mix with those from different backgrounds. ${ }^{95}$ But he also believed that the end of empire would deprive young people of a valuable outlet for these ideals, a concern held by other colonial officials at the time. When writing in The Times, Dickson quoted one serving officer:

Twenty years ago they would have been an obvious choice for an Assistant District Officer. Now of course he is more likely to become a History master at a school in Britain... I only hope the contracting of bounds of empire do not cut off such young men and the people of other races from mutual co-operation..$^{96}$

Family connections to overseas service shaped Dickson's own background. His father had been a civil engineer working across the globe, while his older brother joined the Colonial Education Service in North Borneo. Having started a career in journalism in the 1930s, Dickson served in East Africa during the Second World War, where he launched a mobile propaganda unit aimed at buttressing British support among the local population. ${ }^{97}$ After returning to Europe to participate in more resettlement work, he joined the Colonial Service in 1948, and was posted to West Africa as a social development officer, where he remained until $1954 .{ }^{98}$ In this role, he participated in a number of mass education and community development training schemes, intended to inculcate leadership and teamwork values, which the Colonial Office identified as essential to shaping responsible citizens in preparation for self-government. ${ }^{99}$

The philosophy Dickson developed during this time informed much of his subsequent trajectory. ${ }^{100} \mathrm{He}$ believed vehemently that the optimism, energy and innocence of youth represented the surest means of breaking down racial and cultural barriers in a decolonizing world. ${ }^{101}$ In so doing, individuals gained through selfless service to others. ${ }^{102}$ Dickson was convinced that the era of 'development' could not be successful if it relied only upon 'expatriate expertise' or impersonal aid packages. It required instead a process of reciprocal teaching and friendship between European and local elites; development had to rely upon human interaction to tackle the mundane problems of daily life. ${ }^{103}$ At the heart of his philosophy stood an amateur ideal, which ran against prevailing technocratic trends but emphasized the same ethos of worthwhile service to others proclaimed in Colonial Service publicity and which reflected Dickson's own educational background at public school and Oxford during the interwar years. ${ }^{104}$ 
Dickson first approached the Colonial Office in 1956, hopeful that his vision would chime with their focus upon community development and ideas of Commonwealth. Although he was not rejected outright, he met with considerable circumspection. ${ }^{105}$ Wary of sending a young, untrained cadre of volunteers into increasingly politically unstable societies, many in the Colonial Office preferred to rely upon trained experts rather than well-meaning amateurs. ${ }^{106}$ Dickson's personal reputation within the Service was equally problematic. ${ }^{107}$ Failing to find the affirmation or financial support required, he turned instead to missionary groups already engaged in development work overseas, and in early 1958 persuaded the Bishop of Portsmouth to pledge his support in an open letter to The Sunday Times. ${ }^{108}$

VSO conspicuously and deliberately eschewed any mention of, or allusion to, colonialism; Portsmouth couched his appeal in the same language that had come to dominate Colonial Service recruitment literature, however. These opportunities would be of 'inestimable benefit to the development of the Commonwealth' and provide the foundations for mutual respect between the peoples of newly self-governing nations and Britain. At the root of the proposal lay an acclamation of the value of humanitarian service: 'Equally urgent is the need for the best of our young people - in their difficult period of transition before university or career - to have the opportunity of doing something worthwhile, where it is most genuinely needed, and seeing a bit of the world into the bargain. ${ }^{109}$ In articulating a new vision of British engagement with the wider world, VSO clearly distinguished itself from the colonial state; volunteers would not be taught to govern arrogantly but to better themselves through immersion in a new culture and working alongside peoples who were their equals. ${ }^{110}$

Nonetheless, in a variety of ways, Dickson's Colonial Service connections were essential to establishing VSO. ${ }^{111}$ When identifying projects, he found ready support among more progressive officers, who helped arrange placements across five territories for the first batch of volunteers. Following initial success, VSO quickly grew in popularity and ambition, and by the early 1960s it was receiving over 1,000 applications per year. ${ }^{112}$ Two more former colonial officers were appointed to expand Dickson's one-man show and assist with day-to-day administration. ${ }^{113}$ Edward Chadwick became deputy director, having previously been pivotal in pioneering community development programmes in Nigeria, where he had also been Dickson's superior. ${ }^{114}$ Another ex-Nigeria DO, Gilbert Stephenson, was charged with developing the public affairs and fundraising operation. ${ }^{115}$ Its governing council exhibited a similar 
profusion of colonial connections. Although VSO began without any formal government support, the Colonial Office quickly offered its implicit endorsement. The Secretary of State for the colonies, Alan Lennox-Boyd, received the first volunteers at the Colonial Office before their departure and remained an active and enthusiastic supporter. ${ }^{116}$ Following the success of the first year, however, the British government offered more significant patronage. In 1959 the Colonial Office provided a $£ 9,000$ grant and helped expand the scope of placements across the Commonwealth. ${ }^{117}$

It quickly became clear that VSO targeted the same social elite that had formed the bulwark of Colonial Service recruits. Dickson and his colleagues relied on ready access to public school networks to generate interest, with the first eighteen volunteers coming from public schools. Although the background of recruits expanded in the second year, with a roughly equal split between public and grammar school pupils, VSO remained an elite concept and organization. ${ }^{118}$ The Daily Express did not miss this point, noting in 1959 that it was 'an organization for public school and grammar school boys'. ${ }^{119}$ Volunteers were selected according to criteria that bore remarkable resemblance to Colonial Service recruitment procedure, and, indeed, during the early years included a retired Colonial Service resident on its interview panel. ${ }^{120}$ Personal references lauded precisely the same qualities considered so important among colonial administrators. ${ }^{121}$ Reviewing the second year of service in 1959, The Times included examples of several testimonials, written by headmasters, that most certainly would have won the approval of a Colonial Service selection board: 'Head of school, captain of rugger; cricket and boxing colours; leader of school orchestra, chairman of art society; under-officer, Combined Cadet Force. A boy of strong character, moral and physical courage, integrity and vision; is shrewd, mature, versatile and energetic.. ${ }^{122}$ Promoting its initial success, a VSO publicity release celebrated the 'very high standard of volunteer' and reminded readers that ' $\mathrm{h}$ ] alf of those volunteering for the first projects had been head boys who had already won open scholarships'. ${ }^{23}$

Despite fundamental differences between an application to the Colonial Service and a year or two spent on VSO, volunteers' experiences had much in common with what an earlier generation eagerly anticipated upon an application to the Colonial Service. ${ }^{124}$ All recruits wrote letters back to Dickson, which became publicity to attract more young adventurous volunteers, promising experiences that Stephenson likened to the lot of a DO. ${ }^{125}$ But relying so heavily on former colonial officers to implement a radical new philosophy quickly exposed tensions between paternalistic ideas of service among an older generation and the new emphasis on 
friendship. In 1961 the British Council complained over Stephenson's monthly newsletter, reporting that volunteers in Ghana had been angered by his 'smug and self-congratulatory' tone, which 'tended to suggest that people overseas were comic and extraordinary'. Stephenson's background as an interwar DO came to the fore as he commented on 'darkest Ethiopia' and Thomas Gray's Ode on a distant prospect of Eton College and endorsed a quotation from a volunteer in Bechuanaland: 'The minds of the people are those of children who need help desperately if they are to take on the responsibilities of what are to them at the moment merely romantic dreams, not even political ideals.' ${ }^{126}$

British Council entreaties stressed that, for VSO to be a success in newly independent nation states, it was 'absolutely fundamental' that volunteers and organizers alike accepted those among whom they volunteered as 'dignified human being[s], and the equal of the white man in every respect'. Any trace of 'patronage or condescension or ridicule' would undermine the entire basis of overseas voluntary service, as ' $[\mathrm{t}]$ he African is no longer prepared to be done good to by people who do not in every way show that they accept him as an equal. ${ }^{127}$ Moving slowly beyond the established parameters of colonial rule to construct new relationships between young Britons and indigenous people took time and adaptation. For all the innovation that Dickson's vision promised, it also suggested the possibility for a continuation of more traditional perspectives. Despite some initial grumbling among colonial governors that VSO recruits were ill-suited to the challenges of colonial territories, the general impression is that many officers responded well to the injection of youth. ${ }^{128}$ Nonetheless, just as former Colonial Service officers had to adapt to new and uncertain terrain, so young Britons were also able to start to explore the new dynamics and relationships made possible in a postcolonial world.

The presence of independent-minded teenagers prepared to challenge (or ignore) entrenched social and racial protocols exposed deeper tensions between the volunteers and an older generation of expatriate Britons living across colonial and newly independent territories. ${ }^{129}$ One volunteer outraged the governor's wife in Sarawak by arriving for dinner at the residency dressed in a sarong, but the dispatch of the first female volunteers in 1961 sparked new points of concern, particularly surrounding their interactions with local men. ${ }^{130}$ In Malaya, the local Anglican archbishop complained to Dickson at one female volunteer's behaviour, while another sent in 1962 was reported to the high commissioner for having an 'affair' with a local Sikh man. Despite being interviewed about her behaviour she remained resolute that she had nothing to be ashamed 
about, and, when asked what her parents would think, responded that 'they do know and raised no objection'. In spite of the accusations, the volunteer made an overall favourable impression, with the high commissioner observing traits for which many a male colonial officer had won praise: '[S]he is the least volatile of the girls, calm, intelligent and serious... She is obviously the only girl in the party likely to have taken "A" level in pure and applied maths.' ${ }^{131}$

Indeed, many volunteers appeared determined to challenge local preconceptions by conspicuously disassociating themselves from the pomp of the colonial period. In a newspaper interview with the Malay Mail, the aforementioned volunteer made it clear that she wanted to challenge Malays' 'two dimensional view of Britain - all pomp and pageantry and straw cottages' which had been so rigorously maintained by the colonial elite: 'I had to assure them there is a seamy side to Britain too. It really meant tearing down some pretty solidly built illusions.' ${ }^{132}$ Records testifying to volunteers' motivation or their post-university careers are not readily available. ${ }^{133}$ Nevertheless, it is worth mentioning that at least two 1959 VSO volunteers joined the Colonial Service, with McCleery praising one's idealism, progressive racial attitude and the galvanizing effect of his year in Sarawak. ${ }^{134}$ A third VSO volunteer, also appointed to Northern Rhodesia in 1961, withdrew because he did not think Africa somewhere to take his fiancée; all his referees drew attention to the 'sense of vocation' he had gained through his volunteering, however. ${ }^{135}$ Even so, a somewhat cynical response from his Colonial Service interviewers wondered whether his 'idealism' and 'sincerity' masked a 'naivety' and lack of 'toughness' that would prove problematic in the field. ${ }^{136}$

\section{Conclusions}

In 1962 Sir Ralph Furse published his memoirs. For a title, he chose the name of a mythical Greek bird snarer, Aucuparius, and in elegiac tones acclaimed the system he had created and the Colonial Service as he wanted it remembered. At the book's heart ran a paean to the gentlemanly code of service and duty that defined Furse's essential sense of empire. ${ }^{137}$ Like the title, however, his central theme sat uncomfortably in the context of early 1960s Britain, its nostalgia for a vanishing empire in stark contrast to Anthony Sampson's contemporaneous dissection of a calcifying nation. Furse received positive reviews in the conservative press, particularly from former colonial governors, ${ }^{138}$ but others were already more circumspect. 
Writing a year later, a former Kenya DO, John Nottingham, eloquently exposed the flaws at the heart of Furse's 'apologia':

It is arguable that had our colonial civil servants been less snobbish and paternal, had they been selected for their brains rather than their 'character', such disasters as the emergencies in Kenya and Nyasaland would have been avoided. Sir Ralph and the Oxford clique have much to answer for. Their manifest good intentions may not be a sufficient plea in mitigation. ${ }^{139}$

The tensions and contradictions that stood at the heart of the Colonial Service's ethos after 1945 produced competing visions for what shape the future should take. Ultimately, recruiters' staunch attachment to long-established tropes of character and conditioning sat uncomfortably within the changing domestic climate, making it impossible for the Colonial Service to adapt successfully to the waning of imperial power.

The same year also saw the end of Dickson's association with VSO following a series of clashes with Whitehall over future ambitions. Even as a further 243 volunteers were dispatched to forty-nine territories across the globe, the arrival of President Kennedy's newly formed Peace Corps made many in Westminster worry that Dickson's amateur ideal was simply not adequate for the United Nations' Decade of Development. Throughout the 1960s VSO's reliance on government funding grew, and with the increased funding came increased pressure to refocus on graduate volunteers and technocratic expertise. ${ }^{140}$ Even so, the promise of service to others, adventure and unique experiences overseas continued to hold as much appeal to young audiences as careers in empire had for a previous generation. Interestingly, the funding of VSO schemes in the twenty-first century was proposed by the Overseas Service Pensioners Association as one strategy to rehabilitate the colonial record '[i]n view of the fact that the ideals and motives of people who wanted to serve overseas were very much the same'. ${ }^{141}$

VSO, as embodied in Dickon's philosophy, gave voice to a particular vision of the future that some Colonial Service officers imagined possible, though could not accommodate. The links between the two organizations, both conceptually and tangibly, emphasize the ways in which this was a future imagined on the basis of a changing empire, and one that sought to underline the constant of duty amidst a turbulent climate. These physical and mental entanglements ensured that the end of empire was not the final point of decolonization, and, 
instead, demonstrate one way in which vast interconnected networks of power, spanning Britain, her former colonies and the many individual lives shaped through this association, would endure in new ways. Continuing today, VSO has so far sent over 50,000 volunteers to undertake 'worthwhile service' overseas. 


\title{
Protecting empire from without: francophone African migrant workers, British West Africa and French efforts to maintain power in Africa, 1945-1960
}

\author{
Joanna Warson
}

The study of France and Africa in the late colonial period has frequently centred on francophone Africa. This francophone bias, in turn, is closely intertwined with the growing importance of Africa to France as a means of great power status from the post-war period onwards. The humiliations suffered during the Second World War, alongside the vital role that France's African colonies played in the defence of Free France, enhanced the significance of maintaining an empire, particularly in Africa. ${ }^{1}$ A clear declaration of this sentiment was made at the Brazzaville Conference in early 1944, organized by the French Committee of National Liberation, to signal France's commitment to reform and development in Africa. ${ }^{2}$ Yet, despite recommending significant reforms to the French colonial system, 'any possibility of evolution outside the French imperial block' and 'the eventual creation, even in the distant future, of self-government in the colonies' was explicitly ruled out. ${ }^{3}$ Thus, in spite of the growing tide of anti-colonial nationalism in the post-war era, the French maintained the belief that 'the only independence they [the Africans] will want will be the independence of France'. ${ }^{4}$

With a few notable exceptions, ${ }^{5}$ France's dogged commitment to maintaining its colonial sphere has contributed to a scholarly neglect of French involvement in areas of the African continent outside their traditional sphere of influence. Similarly overlooked are the connections between francophone and non-francophone territories. In the post-war period, however, African interconnectivity was greater than ever before, with the Second World War bringing 'to light the strategic and economic 
importance of the continent as a whole'. Henceforth, according to one official from the French Ministry of Foreign Affairs, francophone and anglophone Africa were 'closely intertwined with each other'. ${ }^{6}$ Thus, at a time when the momentum for freedom from European rule was starting to grow in Africa, connections across colonial boundaries increased. These connections highlight the extent to which the decolonization process was not bound to the inevitable creation of new nation states. Within these connections was a contingent vision of transnational engagement, which prioritized migration, communities and diaspora over the borders of the nation state. Although there has been a rise of comparative histories of decolonization in recent years, ${ }^{7}$ there remains only limited work on the connections between the ends of empire in the twentieth century. ${ }^{8}$

It is the aim of this chapter to challenge the francophone bias of the existing literature concerning Franco-African relations in the post-war period, while simultaneously bringing to the fore previously unknown connections between the ends of European colonial rule on the African continent. It will achieve this aim through an exploration of French responses to the mass migration of francophone Africans to neighbouring British West African colonies in the aftermath of the Second World War. The first part of this chapter unpicks French views of francophone African migrant workers living in neighbouring British colonies, focusing particularly on French concerns about the negative consequences of this migration for francophone Africa, notably in terms of labour shortages. These fearful colonial futures steered the hand of French administrators, worried about their subjects being attracted by British colonial policy or anglophone African nationalism. In the second part, this chapter addresses French efforts to respond to this threat, both within its colonies and beyond the borders of francophone Africa. This case study exemplifies the entanglements of the late colonial and decolonization eras, and offers a new insight into the ways in which France sought to preserve its African empire in the post-war period. In so doing, it offers new perspectives on the end of European colonial rule in francophone Africa specifically and the decolonization processes of the twentieth century more widely. The artificiality of colonial territorial boundaries created both concern and opportunity for colonial powers and peoples. The exchanges between anglophone and francophone Africa speak of the porousness of colonial boundaries but also of the ability of local people to traverse the identity groups that colonial authorities sought to place them in and, in the period of decolonization, that nationalist groups sought to impose. The fluidity and exchange were key to the 
social relationships across the region, but they also presented a problem for postcolonial national governments trying to control newly cemented national borders.

\section{Expatriate francophone Africans - or the external threat to the French empire that came from within}

The migration of francophone Africans seeking employment to neighbouring British territories began in the interwar period. Enticed by the availability of lucrative jobs in gold mines and cocoa plantations, Africans from Upper Volta (now Burkina Faso), Togo, Soudan (Mali), Niger, Dahomey (Benin) and the Ivory Coast flooded across the borders into anglophone Africa. The Gold Coast (Ghana), in particular, was viewed as an 'El Dorado, a Mecca for men who want to get rich quick'. For those migrating to anglophone Africa, particularly from poor French-ruled territories such as Niger and Soudan, the Gold Coast was 'a real earthly paradise, where it was possible to make money quickly, especially as affluent goods are not expensive'. ${ }^{10}$ It was not merely the opportunity for enrichment that encouraged francophone Africans to seek employment in neighbouring British territories. Workers were also enticed by the prospect of lower taxes, greater freedoms and, above all else, the opportunity to escape the constraints of forced labour and other labour obligations in French-ruled territories. ${ }^{11}$ Therefore, according to Romain Tiquet, migration can be understood as a protest against colonial constraint. ${ }^{12}$ How did they respond to the labour regimes in British colonies? Did their mobility allow them to circumvent colonial control in both contexts?

The porous and artificial nature of colonial borders further facilitated migration between francophone and anglophone Africa. The movement of people around West Africa was not something new in the colonial era but, rather, built on long-standing patterns of migration established prior to the arrival of Europeans on the continent. This meant that, in spite of the establishment of colonial borders in the late nineteenth century, many African social groups lived divided between French-ruled and British-ruled territories. This was an entanglement that both pre-dated and outlasted European imperialism. Those from the south-east of the Ivory Coast, for example, had relatives living in the Ashanti region of the Gold Coast, while the frontier between British Togo and French Togo 'divided many tribes in two'. ${ }^{13}$ Similarly, the Songhay and Zerma people from areas that became part of Niger and Soudan had long traditions 
of migrating southwards to the Gold Coast. ${ }^{14}$ Therefore, many arriving in British West Africa from francophone Africa would find themselves living alongside members of the same tribe, or perhaps even the same village. ${ }^{15}$ Moreover, in the view of two French ethnographers sent out to study these migratory movements in November and December 1950, European expansion in West Africa in the latter decades of the nineteenth century reinvigorated this north-south migration, as the 'pacification' of the region by the British and the French enabled people living in the north to resume contact with members of their family or social group. ${ }^{16}$ Thus, migration was 'a habit' for the Zerma, the Songhay, the Mossi, the Dagomba, the Bambara and the Fula, to name but a few. ${ }^{17}$ By 1946 an estimated one million francophone African migrant workers were living in Britain's West African colonies. ${ }^{18}$

For the French colonial administration, preoccupied with sustaining influence in francophone Africa after the defeats and disappointments of the Second World War, the presence of a substantial number of French subjects in British West Africa was a grave cause for concern. In the first instance, the voluntary 'exodus' of workers to the Gold Coast contributed to long-standing manpower shortages in French West Africa. ${ }^{19}$ In the words of Frederick Cooper: 'Not only was death reaping the harvest of African labour [in French-ruled territories], so too was Great Britain. ${ }^{20}$ French officials were conscious of this problem and, from the 1930s onwards, discussed measures to reverse the outflow of the African workforce. Under the Popular Front government (1936-1938), officials contemplated providing workers with incentives that mirrored methods employed in British West Africa, such as paying workers a share of the harvest, a common practice in the Gold Coast. ${ }^{21}$ Wages also increased during the Popular Front period. ${ }^{22}$ Nevertheless, a persistent belief that Africans had to be compelled to work, and the resulting commitment to forced labour, limited the extent to which French labour reform could be implemented in the colonies in the interwar period. Thus, large numbers of francophone Africans continued to flow across the borders into British West Africa in pursuit of work. ${ }^{23}$

The abolition of forced labour by the French in Africa following the promulgation of the Houphouët-Boigny law on 11 April 1946 contributed to a shift in patterns of migration from francophone to anglophone Africa, with temporary seasonal migration replacing permanent relocation in Britain's West African colonies. ${ }^{24}$ The reduction in labour obligations in the French colonies did not stem the flow of workers entirely, however, as had been hoped by the French colonial administration. ${ }^{25}$ Moreover, while the Second World War stimulated economic 
growth in the Gold Coast, it had negative consequences in francophone Africa, prompting a new rush to the Gold Coast as soon as the borders reopened. ${ }^{26}$ By 1949 an estimated 800,000 francophone Africans lived in Accra alone. According to the Africa-Levant Department at the Quai d'Orsay, the French Foreign Ministry, this meant that the capital of the Gold Coast was home to 'the largest group of French [nationals] resident overseas' ${ }^{27}$ The persistence of this movement into the 1950s is evidenced in a 1955 letter from the French consul in Accra to the Governor General of Overseas France, which described how 'for many years the indigenous populations of our territories have come willingly and in great number to the Gold Coast in search of work'. ${ }^{28}$ This voluntary expatriation took on a new significance in the paradoxical post-war era, in which, in spite of a renewed commitment by the French to maintaining their African colonies, France's hold over its empire was increasingly fragile. ${ }^{29}$ In August 1944 the commissioner for the colonies contacted those responsible for colonial affairs at the Free French Mission in Accra, outlining the French Committee of National Liberation's serious preoccupation with the continued problem of workers 'abandoning their country for the Gold Coast'. ${ }^{30}$

Across the globe in the post-war period, European colonial powers, and in particular Britain and France, moved towards an interventionist 'developmental' colonial state, in the hope that it would make their empires both 'richer and more politically legitimate'. ${ }^{31}$ This shift towards development and reform, in turn, formed part of what Martin Shipway has described as the 'late colonial shift': a fundamental reassessment of the colonial project by colonizer and colonized alike. ${ }^{32}$ This was a contingent moment in the charting of France's colonial future. Although they were not unique to France, these concerns were particularly acute in the French case, given the importance attributed to empire in Africa both in literal and abstract terms. For France, having an African empire was a necessary prerequisite for the restoration of its great power status. Thus, the need to halt the outflow of migrant labour to anglophone Africa struck at the heart of efforts to restore French grandeur after the defeats and disappointments of the Second World War.

France's efforts to reassert its position on the African continent through development and reform were epitomized by the recommendations set out at the Brazzaville Conference of 1944, which included increased African political representation and investment in development projects. ${ }^{33}$ When it came to the francophone Africans resident in British West Africa, there were concerns that this population might be insufficiently aware of the post-war advances in French colonial policy 
as a result of their physical location outside the French empire. In a report following a visit to Lagos in July 1948, the French vice consul to the Gold Coast highlighted the limited attachment to the newly named French Union among francophone African migrant workers living in Nigeria. More worrying still were the sentiments of the most advanced and influential members of Nigeria's francophone African community. According to the French diplomat, évolués living in Lagos saw the French colonial administration as 'excessively meddlesome and not very democratic'. ${ }^{34}$ Moreover, their loyalties were not with Dakar or the French Union but with their territory of origin (in this case Dahomey), and any attachment to France was attributed to familial ties in French territories and the desire to benefit from French protection while living in a British-ruled territory. Worse still, in spite of the new constitution, the francophone African community in Nigeria allegedly closed their eyes to advances in French colonial policy and continued to affirm their hopes for a complete transformation of French administrative methods. ${ }^{35}$

The fast-paced political evolution of Britain's African colonies in the post-war period did little to ease French concerns. The changed internal and international context in the aftermath of the Second World War was acknowledged by the British Colonial Office and contributed to the formulation of a new British approach to African policy, based on notions of 'political advancement' for the continent. ${ }^{36}$ In Nigeria the Macpherson constitution of 1951 led to the replacement of indirect rule with semiresponsible government, while in the Gold Coast a parliamentary system of government was introduced in the wake of the Accra Riots of 1948 . The first elections were held in 1951, with the Ghanaian nationalist who went on to become the first president of an independent Ghana, Kwame Nkrumah, and his Convention People's Party (CPP) emerging victorious. While Ronald Hyam has challenged the extent to which these British policies constituted a strategy of decolonization, it is nevertheless clear that the majority within the UK government accepted the fact that Britain's African colonies would eventually achieve their independence. ${ }^{37}$ The position was expressed openly as early as 1938, when the Secretary of State for the colonies, Malcolm MacDonald, asserted that 'the ultimate, if distant, aim of British colonial policy was the evolution towards selfgovernment', ${ }^{38}$ though this did not necessarily mean independence within a national framework.

By contrast, and as has already been noted above, France remained steadfastly committed to maintaining its African empire. For the French, as Cooper notes, 
the one point which was an absolute, from de Gaulle on down, was that the empire would remain French. The war had proven the value of the empire to France, and the post-war recovery would require both an efficient empire and one whose legitimacy was secure. ${ }^{39}$

This, in turn, contributed to French fears about the spread of anglophone African nationalism among its colonial subjects, evidenced by the concerns raised on several occasions during the 1950s about the potential impact of visits to francophone African territories from Ghanaian nationalists. ${ }^{40}$ Unsurprisingly, there were also fears about the susceptibility of francophone Africans living in anglophone Africa itself, especially those resident in the Gold Coast, sometimes described as les Gold Coastiers. As Jean Rouch, researcher at the Musée de l'Homme, acknowledged in his 1954 report on migration in the Gold Coast, this British-ruled territory was 'the most evolved country in West Africa' in political terms. ${ }^{41}$ This was something attributed to Britain's view of the Gold Coast as the 'pilot African colony', where the policy of self-government could be tested out and refined. ${ }^{42}$

More worrying for the French colonial administration, however, was a growing interest among French colonial subjects residing in the Gold Coast in the Ghanaian nationalist leader, Kwame Nkrumah. The Zerma people, in particular, were active supporters of Nkrumah and the CPP, evidenced by reports of members of this group attending CPP meetings, wearing symbols and shouting slogans that glorified the party and singing songs in praise of Nkrumah. ${ }^{43}$ In 1954, in spite of legislation passed by the British colonial authorities preventing French subjects from voting in legislative elections in 1954 (previously it had not been necessary to be a British subject in order to vote in the elections for local councils), the Zerma demonstrated their support for Nkrumah at the polls, evading legislation by registering themselves as Hausa (natives of Nigeria who, like the Zerma, frequently migrated to Accra). According to investigations carried out by Rouch, some 1,600 out of 2,000 Zerma questioned in Accra voted in the 1954 elections, in spite of the risk of a $£ 50$ fine or three months in prison. ${ }^{44}$

To the French colonial administration, therefore, the presence of francophone Africans in British West Africa created a potential threat to the French empire that came from within but was enhanced by the situation without. This, in turn, demonstrates the way in which concerns about maintaining France's African colonies were not solely concentrated on the francophone world. Rather, the presence of a large number of France's colonial subjects outside its traditional sphere of influence led 
certain individuals and groups to look beyond the borders of the empire in order to shore up power within it. This, in turn, reveals the existence of a much wider French vision of the African continent than has previously been explored by scholars, bringing to light often overlooked connections across colonial borders.

\section{Implementing French colonial policies in anglophone Africa - or protecting the empire from the outside}

France's response to the 'exodus' from its colonies was, like the threat itself, twofold, looking both inwards to the situation in the colonies and outwards to the British West African setting. With regard to the former, there were calls for reforms of French colonial policy, particularly when it came to labour, in an attempt to entice Africans back to French-ruled territories. As in the interwar years, these calls for reform frequently centred on the need to reproduce British approaches towards labour in the francophone African setting. For example, in 1944 the administrator charged with the colonies at the Free French mission in Accra called for the benefits and conditions available to workers in the Gold Coast to be introduced in French West Africa, notably higher salaries, improved working conditions and a diminished administrative burden, in line with the situation in British West Africa. In summary, he argued that 'we must as far as possible create the conditions at home [in French West Africa] that attract workers to the English'. ${ }^{45}$

In the post-war period it is possible to identify several instances of the French colonial administrators seeking to achieve this aim, with increased wages and improved workplace conditions and benefits. The most striking example, however, was the decision to abolish forced labour under the Houphouët-Boigny law of 1946. The 1944 report discussed above made an explicit recommendation concerning the prestation (a policy whereby taxes were paid in the form of forced labour), arguing that the system 'profoundly fatigued' the native populations of francophone Africa ${ }^{46}$ Moreover, the group of African deputies who, in February 1946, submitted to the National Assembly a proposed law abolishing forced labour in all overseas territories made reference to the problems concerning labour migration to British West Africa, arguing that forced labour provoked 'total dissatisfaction of natives in regard to France and an increasingly massive exodus'. ${ }^{47}$ The French National Assembly subsequently approved this African proposal, and forced labour was abolished in the colonies. 
It is apparent, therefore, that, although the French largely failed in their objective to reverse the outflow of labour to British West Africa, there was an important link between the presence of a substantial francophone African population in Britain's African colonies and the evolution of French colonial policy in the post-war period. While there were certainly other factors that informed French colonial policy during this era, ${ }^{48}$ it is nevertheless important to acknowledge the influence of French and francophone African experiences in, and knowledge about, British West Africa, particularly when it came to questions of migration from francophone to anglophone Africa. French efforts to adopt British colonial labour initiatives after 1945 also stand in contrast to the position set forth by Alexander Keese that, despite being 'interested and aware of what happened in British Africa', French colonial administrators 'strongly disagreed with developments' in anglophone Africa and gathered information 'not to learn from British reforms, but to understand if developments on the British side of the border could lead to unrest amongst populations in French Black Africa'. ${ }^{49}$ While the latter statement is certainly true, it is apparent from the above discussion that, in certain instances, British colonial policy was an important reference point for the French.

The second element of the French response to the perceived threat posed by the presence of a substantial francophone African population in anglophone Africa concentrated on British West Africa itself. Up until 1946 the official French presence on the ground in British-ruled African territories was minimal. A liaison office in Accra, linked to the British resident minister in the Gold Coast, had responsibility for the whole of British West Africa. ${ }^{50}$ The only other official French mission in the region was a military and administrative transit post in Lagos. ${ }^{51}$ Many of the employees at these offices were French military personnel, a legacy of their former status as Free French missions. ${ }^{52}$ Both offices were also staffed by employees of the French colonial companies that had operated in British West Africa since the late nineteenth and early twentieth centuries, including the Compagnie française de l'Afrique occidentale (CFAO), the Société commerciale de l'ouest africain (SCOA) and Chargeurs Réunis, as well as other individuals active in West African commerce. ${ }^{53}$ The Lagos post is a striking example of the role played by private actors in the official French presence in anglophone Africa, with an agent of Chargeurs Réunis serving as the head of the post, and two former retailers who had been active in West Africa serving as subordinates. ${ }^{54}$ The participation of private individuals in French diplomatic posts in British West Africa, in turn, can be traced back to Paris' decision in the interwar period to 
station consular agents in Accra and Lagos under the supervision of the French consulate general in London, thus according these offices a large degree of independence and leading to a blurring of the lines between official and non-official French action in anglophone Africa. ${ }^{55}$

In the immediate aftermath of the Second World War, certain individuals at the Ministry of Foreign Affairs and the Ministry of the Colonies (from 1946 the Ministry of Overseas France), as well as a number of 'men on the spot' in London, Lagos and Accra, sought to take control of the situation and formalize the French presence in British West Africa. They sought to make an asset for the future from this imperial entanglement. In early 1945, for example, Henri Laurentie, the director of political affairs in the Ministry of the Colonies, asserted in correspondence with the liaison mission in Accra that it was 'essential that France be well represented in the British colonies on the West Coast of Africa'. ${ }^{56}$ Although there was some delay in responding to this perceived imperative, ${ }^{57}$ a French consulate opened in Accra on 1 October 1946. ${ }^{58}$ Two days later, on 3 October, a chancellerie détachée opened in Lagos, which was responsible to the French post in Africa and had similar functions to a vice consulate (and was frequently referred to as such)..$^{59}$

Various factors underpinned the formalization and expansion of France's diplomatic presence in anglophone West Africa. British activities across the region were an important point of reference from the outset. The UK government's plan to replace the resident minister in the Gold Coast with an under-secretary dependent on the Colonial Office, for example, led to calls from the director of political affairs at the French Ministry of the Colonies for the liaison mission in Accra to be replaced by a consulate. The former, it was argued, had been created specially to collaborate with the resident minister and, therefore, was no longer fit for purpose. Instead, a more formal diplomatic presence was required in order to ensure productive Anglo-French collaboration in the future. ${ }^{60}$ In this respect, the French were responding directly to British demands, notably those from the resident minister in West Africa, Harold Balfour. During a meeting with the administrator responsible for the colonies at the French liaison mission in Accra in January 1945, Balfour criticized the limited functions of the existing French office, calling for a greater administrative or consular presence that would enable 'closer collaboration between the British and French colonies in West Africa' ${ }^{61}$ It is noteworthy that the British consulate general in Dakar, Senegal, was cited as a potential example in this respect, providing further evidence of the importance of the British model in Africa in shaping French policy towards the continent. ${ }^{62}$ 
Alongside the significance of British activity and Anglo-French cooperation, concern for French colonial subjects was paramount in informing the systemization and expansion of France's diplomatic presence in Britain's African colonies. A report prepared by Guy Monod, following a mission to Africa in early 1946 on behalf of the Ministry of Foreign Affairs, stressed the importance of establishing consulates in Accra and Lagos so that indigenous migration from francophone to anglophone Africa could be studied in situ. ${ }^{63}$ France's new consulates in British West Africa were not solely responsible for observing francophone African residents, however. They were also tasked with 'discrete action' towards this colonial population. ${ }^{64}$ Much of this activity focused on improving French colonial subjects' knowledge and understanding of France and its empire, because, as has been noted above, it was believed that the French effort in Africa was 'unknown' among these populations. ${ }^{65}$ Thus, during a visit to Lagos in 1948, the French vice consul to the Gold Coast went to great lengths to stress the benefits of French rule to francophone Africans living in Nigeria, highlighting 'the social, economic and political achievements' of France as well as 'the dedication and work' of French doctors, teachers, missionaries and administrators. ${ }^{66}$ In addition, the French diplomat made requests to Paris for photographic propaganda that could be disseminated among France's expatriate colonial population, including documents depicting the work carried out by the Office of Niger, the port of Dakar and the Pasteur Institute. Images of sporting activities, sessions of the general councils, art exhibitions, 14 July celebrations and opening ceremonies for new buildings, it was hoped, 'would give the image presented a more lively appearance'. ${ }^{67}$ In a similar vein, in October 1949 three advisers to the Assembly of the French Union (Mitterrand, Plagny and Moullec) visited Lagos with the principal objective of making contact with French African subjects resident in Nigeria. Although no large-scale propaganda efforts formed part of this visit, the three Frenchmen did participate in a meeting organized by the Association for French Africans and attended by the French vice consul in Lagos, where they spoke of 'the role and the action of the Assembly of the French Union and the links that unite the metropole and its overseas territories' ${ }^{68}$ These initiatives, in turn, aimed to ensure the loyalty of France's colonial subjects and, thus, help sustain the French empire.

Alongside these direct attempts to secure the allegiance of expatriate colonial subjects, there were also more indirect strategies to foster a sense of French identity among the francophone African community. One striking example of these efforts was the French social centre, which opened in Lagos in 1949 on the initiative of the vice consul in Nigeria, 
Georges Tourot. ${ }^{69}$ According to an interview with Tourot published in the Daily Times, the centre aimed

to eclipse any known scheme of social welfare service ever promulgated in Lagos Colony. The idea behind this modest beginning is to develop the centre into a Club, where French Africans will meet in one cohesive organisation instead of, as at present, frittering away their energy and financial resources in different institutions, thus engendering feelings of rivalry between the leading personalities in the French African community. ${ }^{70}$

In a dispatch to the Ministry of Foreign Affairs, Tourot himself described the aim of the social centre, and the consulate in general, as being

to put into practice the principles of the French Union. We not only initiate the gathering together and protection of our African nationals, we also justify and prove in a way that is in our interest that we support their social development as part of the duties arising from our presence in Africa. ${ }^{71}$

Services offered by the centre included free financial and legal advice, French and English language classes, sports and youth organizations and social events. ${ }^{72}$ The centre also organized monthly visits from a doctor employed by the Health Service in Dahomey. ${ }^{73}$ The success of the social centre in achieving its aims was highlighted in the Ministry of Foreign Affairs' praise of Tourot's work upon his departure from Lagos in 1951. In particular, the report emphasized Tourot's role in 'bringing together the French community in Nigeria', a task that was believed to be 'important and difficult'. ${ }^{74}$ Similarly, in the Gold Coast, French diplomats offered support and services for francophone Africans, including social events. On 14 July 1948, for example, chiefs and other representatives of different indigenous communities were invited to a reception to mark the occasion in the garden of the consular residence in Accra. In the evening a number of these Africans who were deemed to be évolués were invited to join the European French population for a dinner party. ${ }^{75}$ According to The African Morning Post, there 'was dancing to the tunes of a radiogram', with the party continuing until 'about 1 am the next day'. ${ }^{76}$

French consulates in British West Africa played an important role in the lives of francophone Africans resident in the region. It is unsurprising, therefore, that, to many francophone Africans, the French consul was akin to a 'commandant de cercle', the French equivalent of a British 
district commissioner. As such, French colonial subjects resident in Accra or Lagos called upon these diplomats to resolve the multiple difficulties in their lives. According to the French consul in Accra, Charles Renner, ' $[\mathrm{N}] \mathrm{o}$ business is too large or small for one [a francophone African] to come to him [the consul] for advice.' Entanglement at state level was reflected in the contact sites between communities, with the fulfilment of everyday social functions helping to steer policy higher up the chain. As such, the consul might be called upon to admit complicated rights of inheritance, arbitrate a dispute, search for a woman who had left her husband, obtain reimbursement for a debt or facilitate entry into a school or a money transfer. ${ }^{77}$ The extent of this workload led those on the ground to request additional support from the Ministry of Foreign Affairs, notably additional personnel to deal with colonial administration. ${ }^{78}$ The significance of French diplomats in the lives of francophone Africans resident in British West Africa is further evidenced by the participation of a number of 'distinguished natives of French territories' in the reception to mark the departure of Tourot from his post in Lagos in April 1950. ${ }^{79}$ The consul was, therefore, pivotal in the lives of many francophone Africans resident in anglophone Africa, taking on a role that far exceeded that of a normal consular agency.

Thus, despite being overseas representations, French diplomatic posts in West Africa also fulfilled the functions of the colonial administration. They sought to act on behalf of the Ministry of Foreign Affairs and the Ministry of Overseas France simultaneously and took on the roles of colonial administrators despite the fact that they were physically located outside the borders of the French Union. This is a situation that was explicitly set out in the report on Monod's visit to Africa on behalf of the Ministry of Foreign Affairs in 1946. According to this document, the principal objective of the new posts in British West Africa was to execute colonial policy. ${ }^{80}$ In a similar vein, the French consul in Accra described in a 1950 dispatch 'the particular character' of the French post in Accra, as it was 'situated in a colony surrounded by French territories, with several hundreds of thousands of people from these territories with French citizenship'. ${ }^{81}$ The fact that many of those who served at the French consular posts in British West Africa had experience of work in the colonies underlines this blurring of the lines between the colonial and diplomatic functions of the posts in Accra and Lagos. Prior to his posting in Lagos, Tourot, for example, had worked for sixteen years within the French colonial administration. ${ }^{82}$ Similarly, a 1945 note from the French post in the Gold Coast to the British colonial secretary described how the French consul in Accra 'will be assisted by one or two officers having experience in colonial 
affairs'. ${ }^{83}$ The colonial function of France's diplomatic offices in British West Africa is further evidenced by the importance that the Ministry of the Colonies ascribed to these missions. ${ }^{84}$ By establishing a formal diplomatic presence in anglophone Africa, the French were, therefore, conducting colonial policy outside their colonies with the aim of protecting the empire from the outside. This, in turn, reveals the existence of a much wider French vision of Africa in the post-war period, which extended beyond the colonial context to include the continent as a whole.

\section{Conclusions}

French fears about the susceptibility of francophone Africans to anglophone African nationalism - with the exception of those from the French mandate of Togo - proved to be largely unfounded. A report from the French consul in Accra, from 1955, for example, claimed that the French African emigrant, even one who has lived [in the Gold Coast] for a number of years, does not consider it home'. ${ }^{85}$ This claim was supported by some discreet investigations carried out by the French consul into whether there was any demand for a French language school for the children of francophone African workers resident in the Gold Coast. The response was resoundingly negative, with nearly everyone surveyed recorded as saying that they wanted their children to be raised in their country of origin, that is to say, in a French territory, because they would like to maintain their links there'. The growing number of Africans applying to the French consulate in Accra for a French passport further enhanced the French conviction in the loyalty of francophone Africans to the French Union. ${ }^{86}$

This type of evidence also contributed to the belief that francophone Africans had little interest in British West African politics. Any political engagement - such as the support given to Nkrumah by the Zerma, discussed above - was soon reduced to competition between different native groups. Characterizing these migrants by the boundaries they crossed, therefore, can obscure the significance of their links to the communities of their birth. These migratory populations did not draw on their mobility as a strong point of identity; rather, it was the memory of their lingering social and cultural entanglements that marked the nature of their migration. Francophone Africans living in Accra, for example, attempted to demonstrate that they had the same rights as other foreigners resident in the Gold Coast, namely those from British-ruled Nigeria. ${ }^{87}$ There was also the growing perception that the experience in British West Africa actually increased francophone African loyalty to the French Union. 
The report from the French consulate in Accra in 1955 discussed above asserted that the francophone Africans of the Gold Coast were troubled by the political evolution in this British territory and feared the prospect of living under a government that was entirely composed of Africans. ${ }^{88}$ Their vision of the colonial future had, in turn, been developed in reference to their long-standing entanglement with francophone Africa. In a similar vein, Rouch concluded in his report on migration to the Gold Coast that it would be absurd for colonial administrators to consider these emigrants 'as agitators ready to preach a crusade for the independence of French Africa' as a result of their preference for the French system over the British. ${ }^{89}$ In particular, Rouch argued that francophone Africans failed to understand the British approach and thought that the British wanted to leave the Gold Coast because 'they don't like Africans'..$^{90}$ For both the migrants and the colonial administrators who governed them, the contingent possibilities of their future in anglophone Africa were defined by their francophone entanglement.

Although French fears about the threat posed by francophone Africans resident in British West Africa proved to be unfounded, this case study is significant for our understanding of France's approach to the African continent during the age of decolonization. It demonstrates how the interconnectivity and interdependence of the African system in the post-war period forced France to look beyond its colonial borders with a view to maintaining its sphere of influence in Africa. Of particular concern were French colonial subjects who, by living and working in anglophone Africa, posed a potential challenge to French colonial rule that was simultaneously internal and external. French attempts to deal with this perceived double-sided threat, in turn, influenced France's approach not only to its colonies but also to the African continent as a whole. With regard to the former, French efforts to prevent the migration of its colonial subjects to anglophone Africa influenced some of the reforms implemented in the post-war period in an attempt to ensure that francophone Africa remained French. In the case of the latter, initiatives aimed at providing for colonial subjects living in anglophone Africa prompted the systematic expansion of France's formal presence in Africa outside its colonial empire. This, in turn, set the stage for a much wider French engagement with the African continent in the post-independence period. ${ }^{91}$

Thus, in contrast to much of the current literature, which has emphasized the particularity of France's relations with francophone Africa, the responses of the French to their expatriate colonial subjects demonstrate the existence of a much wider French approach to the African continent 
from the post-war period. Colonial problems were not confined solely to the francophone African setting, and colonial policy was not informed purely by experiences within the French empire. Rather, during the age of decolonization, challenges to French colonial rule, along with efforts to resolve these potential threats, were entangled with events in anglophone Africa. Unpicking this web of entanglements is vital to fully understanding the end of French rule in Africa and its aftermath, as well as wider processes of decolonization in the twentieth century. 


\title{
Conclusion: the conditional as a category
}

\author{
Chris Jeppesen and Andrew W. M. Smith
}

The ways in which the future is forecast, when we speak in the conditional, are intimately bound up with our assessment of the present. After the Second World War, when this volume has stressed the notion of a late colonial shift, there was a period of profound change, creating a mass of swirling possibilities in Europe and in Africa. In 1950 Keïta Fodéba described an 'African dawn', as the ruptures of wartime and imperial conflict interrupted the rhythms of village life. ${ }^{1}$ There was a sense, for some, that natural forces were undermining empire, but also that they could spark its renewal. For European powers, this late colonial shift offered the chance to reconstruct empire as a modernizing force committed to development and an essential, stabilizing structure within the new constellations of Cold War rivalry. For those living under colonial rule, new claims could be made for economic and political equality, while white settler communities saw the chance to assert a colonial future that might entrench white control in Africa. All the while, for anti-colonial political and intellectual elites, it seemed that a global discourse of rights should secure colonial emancipation.

The conditional assessment of empire was not simply the task of states. Ordinary people, activists, businesses and even historians all imagined their own futures. As demonstrated by Michael Collins in Chapter 1, these visions were not limited by, or within, bounded spaces or official channels. Instead, they ranged across local, national, imperial and global forums to try and make real the ambitions hoped possible. Removing the definite ending from our imperfect view of the past does not necessitate a counter-factual discussion of flags and federations, but can open a smaller window on a social history of ideas inflected by the context in which they emerged. This volume has sought to stress the uncertainties of the end of 
British and French empire in Africa as a means of interrogating the contingent nature of the decolonization process. Competing visions of what this change might entail vied throughout the 1950s, and, in turn, created new openings that promised alternative futures, regardless of their realization. In emphasizing three central themes of development, contingency and entanglement, the essays in this collection have sought to tease out how some of those futures were imagined, why some succeeded and why others fell away. As Frederick Cooper notes: 'Imaginative projects have material consequences.' ${ }^{2}$

Colonial development was central to this reimagining. The reshaping of colonial societies never unfolded as European planners hoped, however; Africa would not be Europe's blank slate. Far from revealing the hegemonic, modernizing power of empire, development schemes often exposed the limits of colonial authority and the necessity for negotiation. Development became a field in which competing claims on the future could be made, and, simultaneously, the battleground upon which those visions were resisted. In charting the distance between metropolitan ambitions and local realities, the chapters in this volume suggest fresh insight into how development initiatives contributed to the contingent ends of empire. In Chapter 2, Charlotte Riley traced debates about aid and development within the Labour Party from the post-war moment, when policy-makers still imagined a bright colonial future, to the postcolonial world, when development remained central to policy-makers' vision of progressive engagement with African states. Continuity in personnel and ideas ensured that the transfer of power did not precipitate a fundamental rupture in development policy but that new initiatives often built upon enduring colonial entanglements. In Chapter 3, Marta Musso looked at how Algerian oil became a contingent factor at the turbulent end of French empire in North Africa. Throughout the War of Independence a range of actors on both sides, at and below the level of the state, sought to exploit the developmental promise of hydrocarbons to cultivate allies, dominate debates and make deals in pursuit of a vital resource. In both chapters, we see how the promise of future developmental engagement was wholly contingent on ideas of sovereignty defined in the conditional. European powers emphasized developmental entanglements to ensure continued access to markets and resources, while newly independent governments often forfeited sovereign control over territorial resources to preserve economic ties to Europe. Understanding the conditional sense of decolonization helps to explain the performative aspect of continued European involvement in Africa. Between aid parcels branded with the Union Jack and ephemeral Saharan oil contracts drawn up by the embattled French 
state lies an insight into how the politics of development were contested during the ongoing process of decolonization.

Each aspect of these contests was refracted through the many individual perspectives that made up the imperial nation state. By looking at the ways in which individual decisions formed amidst the rapidly changing climate of the 1950s, we can begin to cut across those perspectives to consider how those living through the ends of empire responded to the wider changes unfolding around them. In Chapter 4, Andrew Smith argued that, by understanding the way these visions of the future were shaped by specific moments in the late colonial state, we can better untangle the ongoing process of decolonization. By placing specific documents within their ideational context, it is possible to look more closely at the ways in which discourse was shaped by the broader entanglements that surrounded it, both personal and political. In Chapter 5, Robert Skinner considered how the concept of human rights took on a new inflection as the process of decolonization accelerated. Skinner showed that the history of human rights, and its strong association with sovereignty, was contingent on the entangled history of decolonization. From Sharpeville to the United Nations, on to West Yorkshire and back to southern Africa, networks of transnational activists emerged from the particularities of local violence. Amidst the breakdown of empire, these networks became essential conduits in mobilizing global opinion against the enduring iniquities of white rule in Africa. In both these chapters, we can see how a dense, interconnected and diverse range of debates shaped and were shaped by the end of European empires and the ongoing process of decolonization. By tracing the discourse, or studying the moment in which these ideas were framed, we get a sense of how placing decolonization in the conditional tense opens new opportunities for analysis.

Focusing on these moments and on these discussions means looking at the messy ways in which formal empires split apart. From this, we gain a pronounced sense of the complex mental and material entanglements that survived flag independence. In Chapter 6, Chris Jeppesen looked at changing ideas of service and duty in the late colonial state. The Colonial Service's recruitment crisis in the 1950s exposed the irreconcilable tensions between its traditional institutional ethos and the new priorities of the revised colonial mission. As careers in empire lost their popular appeal, new organizations, such as VSO, offered alternative opportunities for service and adventure overseas. The links between the two organizations emphasized the ways in which this was a future imagined on the basis of a changing relationship between Britain and colonial territories, but 
one that sought to emphasize the constant of duty amidst a turbulent climate. The porosity of colonial borders ensured that entanglements existed not only between 'metropole' and 'colony' but between empires themselves, despite the best efforts of cartographers to demarcate European empires as discrete territorial units. In Chapter 7, Joanna Warson charted the dense networks of labour, kinship and trade that crossed colonial borders and imperilled imperial sovereignty. Labour migrancy between anglophone and francophone West Africa exposed the insecurities of flagging empires and highlighted the limited ability of the late colonial state to impose control on the actions of indigenous people. Looking at how colonial administrators sought to untangle these links shows how they themselves imagined the future of African development and projected French influence forwards. Both these chapters captured the late colonial state as a contested space in which the 'official mind' sought to impose control on the turbulent currents starting to erode colonial authority. Exploring these often futile efforts reveals the internal contradictions that stood at the heart of Britain and France's revised colonial missions. The desire to impose a vision of a consensual and ongoing colonial future through often frenzied planning belied the limits of colonial control in the everyday lives of many indigenous people. Yet this planning also made possible unexpected, though enduring, entanglements between newly independent states and postcolonial powers.

The contradictions of decolonization need not hinder its discussion, nor limit our frames of analysis. In looking at the three key themes of this volume - development, contingency and entanglement - it is clear that they overlap and intersect as analytical categories. This is a productive tension for understanding the ways in which imperial legacies lingered and systemic inequality persisted, even as new languages of liberation found an ever greater audience. The force of the future imperfect lies in its conditionality, and, in trying to rescue that sense of the conditional, the entanglements of the late colonial state gain traction. In this space delimited by time instead of place, we can gain an insight into the importance of the post-war moment as a period in which processes of change were accelerated, and perceptions of the future recast. Exploring visions of the future can open up a sense of the late colonial shift as it occurred, privileging an anti-teleological reading of these transformative decades. By seeking to untangle the asymmetric interactions of individual actors, larger global networks and specific governments, the link between imagining and acting the end of empire becomes clearer. Using the conditional as a category, 
we can begin to unpick the developmental, contingent and entangled threads of the imperial nation state as it planned imaginative projects in Europe and Africa.

By 1965 Keïta Fodéba envisaged a 'new dawn of African freedom'; winds had seemingly calmed and tides ebbed, leaving behind only the crumbled remnants of Britain and France's African empires. As this volume has sought to explore, however, decolonization was never an irresistible force of nature but a contested, uncertain and contingent toand-fro, which unfolded in the conditional and left entangled pasts to shape future possibilities. Bright though Fodéba's new dawn seemed in the mid-1960s, it should not blind us to the blurred alternatives glimpsed in the twilight of empire. 


\title{
Afterword: Achilles and the tortoise: the tortoise's view of late colonialism and decolonization
}

\author{
Martin Shipway
}

As the battle of Borodino draws to its wearied and bloody end, in volume three of War and peace, Leo Tolstoy reflects on a day that, while militarily inconclusive, ultimately led to the defeat of Napoleonic France, 'a country on which, at Borodino, for the very first time, the hand of an opponent stronger in spirit had been laid'. Turning the page, Tolstoy then turns his attention away from his narrative, to the problem of historical time and causation, drawing a parallel with Zeno of Elea's best-known paradox, 'whereby a tortoise that has a head start on Achilles will never be caught up by him, even though Achilles is walking ten times faster than the tortoise'. ${ }^{1}$ In the time it takes Achilles to reach the tortoise's starting point, the tortoise will have gained on him, and so on ad infinitum; the mathematical resolution of the paradox need not detain us, though Tolstoy dismisses it perhaps too readily as a 'fallacy'. But the way in which Tolstoy expounds his analogy with the 'search for the laws of historical movement' offers some cautionary lessons for us as historians of decolonization.

Writing in the 1860s, at a distance from the events of 1812 similar to our own from the climactic 'year of Africa', 1960, Tolstoy's perspective on the entire Napoleonic period offers the loftiest of 'aerial views' (to borrow from Michael Collins): '[A]n extraordinary spectacle - millions of men in movement. Men drop their normal occupations and rush from one end of Europe to the other, plundering, slaughtering one another, experiencing triumph and despair, and the whole business of life is disrupted for years to come...' ${ }^{2}$ Tolstoy, of course, had his own agenda: not only the condemnation of war and all its works, but also an assault on the 
myth of Bonaparte's genius, and more generally on the agency of 'great men'. If his alter ego is Count Pierre Bezukhov, wandering the battlefield at Borodino, excited but uncomprehending, the exemplar of his view of history is Marshal Kutuzov, who alone understands that history will take its course however he intervenes, and who finally recognizes that there is nothing left to do but die. 'And die he did.'3

Just as Achilles does, of course, outpace the tortoise with ease ('as any fule kno', Nigel Molesworth might interject, looking over Count Lev Nikolayevich's shoulder), so it sometimes seems that our object of study, the end of the European colonial empires, may all too readily, as Tolstoy puts it, be 'blown away like dust, leaving no trace behind, simply by selecting a greater or smaller discrete unit for analysis'. ${ }^{4}$ Especially greater. On the one hand, the 'twenty-year crisis' of post-1945 decolonization was played out, as I have argued elsewhere, at the hectic pace and accelerating timescales of l'histoire événementielle. ${ }^{5}$ This necessarily left room for contingency, or, as one might put it more plainly - recalling Harold Macmillan's possibly apocryphal quip that it was 'events, dear boy, events' that he most feared - for things to go wrong. From this perspective, decolonization and its aftermath were so ragged and unpredictable, so much a matter of hurried negotiations and hastily improvised, if grandly executed, 'transfers of power', followed by more or less orderly imperial retreats, and by greater or lesser degrees of post-colonial chaos, that actors at the time necessarily found themselves reaching for larger explanations: trysts with destiny, national liberation, 'freedom in poverty rather than riches in slavery', winds of change, tides of history or even, quite simply if tautologically, a newly invented 'decolonization'. On the other hand, returning to Frederick Cooper's dictum, already quoted by the editors at the outset, given that 'we know the end of the story', not only do we all reach for some larger explanation as to why decolonization happened - and I do not need to renavigate the terrain so comprehensively mapped out by Michael Collins in this volume - but we also most likely subscribe to the view that it was somehow 'inevitable'. And yet, though we as historians of decolonization might concur that the dying colonial empires, like Napoleon, were defeated at the 'hand of an opponent stronger in spirit', we might nonetheless resist either or both of the two broad theses expounded by generalist historians on an ideological continuum extending from Niall Ferguson to Eric Hobsbawm, by public commentators and by our own undergraduate students: either that the inevitability of the end of colonial empire was so irrefutable as to require no further explanation, other than perhaps a misplaced nod of congratulation to the British on how 'well' they managed their imperial retreat; or, 
conversely, that it was so trivial or so cynically stage-managed an event that the underlying forces of (Western) imperialism, racial domination or globalization continued largely unchecked, or indeed were reinvigorated by the process.

The historian of decolonization, blinking in the late afternoon sunlight of Kew or Aix-en-Provence after another day in the archives, may tend rather to the tortoise's perspective. Here, the tortoise looks apprehensively over his shoulder (and, if he was a colonial official, he was almost certainly male) as Achilles bears down inexorably, perhaps urged on by Walter Benjamin's 'angel of history', as deployed so evocatively by Benedict Anderson. ${ }^{6}$ And yet, that same official continues writing, planning, reforming, accumulating document after document, box after box. Although no more distant from us than Pierre or his more courtly friend Prince Andrey from their creator, reconstructing the point of view of this late colonial 'official mind' offers something of a puzzle: what did these individuals think they were doing? Setting the agenda for a transnational approach to decolonization and globalization, Martin Thomas and Andrew Thompson have proposed a beguiling psychological explanation:

Many acknowledged that the old ways of colonial dominance were becoming untenable. Yet few applied the logic of this insight to their particular colonial difficulties. Supporters of empire instead argued time and again that, despite the countervailing evidence in other places, either resisting rebellion or imposing limited reforms in others might yet achieve success. This was neither blind reaction nor unreconstructed imperialism. Rather, it was something more: a problem of cognitive dissonance, a failure to recognise that the internationalisation of colonial problems and the transnational networks of anti-colonial opposition made the local containment of colonial problems impossible to achieve. ${ }^{7}$

Rooting around in a second-hand bookshop recently, I was reminded that 'cognitive dissonance' has been used before to explain 'ideological polarization', for example during the Cultural Revolution in China. ${ }^{8}$ Persuasive as the idea may be of British or French (and, one might think, even more Belgian or Portuguese) officials grappling to bridge the 'disconnect' between their belief systems ('If I just keep moving, Achilles will never catch me') and what they saw happening around them, the concept turns out, on closer inspection (and as Paul Hiniker's title suggests), to be a variant on the conventional juxtaposition of 'ideology' and 'reality'. As Gary Wilder has argued, this conceptual pairing of opposites has given 
rise to an enduring 'analytic of failure' in French colonial historiography, according to which " "failure" is treated as the condition and horizon of knowledge about colonial history', presupposing a 'narrative of progress against which reformers' failure and success may be easily evaluated'. ${ }^{9}$ It may simply be that Wilder's 'analytic of failure' applied to interwar colonial humanism is at risk of transmuting into a post-1945 'analytic of futile intransigence'. ${ }^{10}$

In any case, I find myself unwilling to break faith entirely with the subjects I have encountered in the archive. As a doctoral student coming fresh to historical research, but mindful of the self-deceiving protagonists of French and German literature I had encountered as an undergraduate, I once asked my supervisor, John Darwin, what I should do if I simply could not believe what the documents were telling me (I do not recall exactly about what, probably French official reformist intentions in Indochina). Darwin's bemused advice - and he was perhaps most concerned that I should not lose the momentum of writing - was along the lines of 'Just tell it as you find it'. ${ }^{11}$ It was good advice, though the historiographical moment for 'Whiggish' belief in a 'planned' decolonization had already passed, ${ }^{12}$ and, in the case of my own research, the 'myth' of Brazzaville et seq. did not bear close scrutiny. As Wilder also urges us, rather than 'enacting' the rights and wrongs of colonial history, or our disagreement with the values of its (imperial) subjects, we need to 'work through' the debates and discourses as we find them. ${ }^{13}$ Andrew Smith's notion of 'expired contingency', expounded in this volume, seems to me to be more congenial than the sustained suspension of disbelief suggested by a diagnosis of 'cognitive dissonance'. It allows us, at least in the first instance, to take at face value the arguments for alternative 'imagined futures' or for the 'future imperfect', as set out by the editors - and not, counter-factually, because of what 'might have happened' but because they may, with patience, lead us to a fuller explanation of what did.

All historians no doubt have epiphanies in the archives of the kind recounted by Smith, but I hope I may be allowed the indulgence of telling one of my own, as it advances my argument. Somewhere in the 'Affaires politiques' files at Aix I found a scrap of squared notecard on which was written, in the unmistakable handwriting of Governor Henri Laurentie, director of political affairs, something like 'Hô - sam[edi], 20h - rue Jasmin'. ${ }^{14}$ It appeared to be the record of a dinner invitation; the address in the sixteenth arrondissement of Paris, was, I guessed, Laurentie's service apartment. With no more precise information to go on, I tucked the memory away, and did not mention it in my doctoral thesis or in the book that followed. ${ }^{15}$ When, much later, I met Laurentie's sons, the memory 
resurfaced, and I put the question to the younger son, Jean: yes, the dinner took place ('How did you know that?'), sometime in August 1946; Jean was present, and 'Oncle Hô' dedicated a children's book to him. ${ }^{16}$ What transpired at the dinner we will never know, nor what they ate, drank or smoked. And, though it is not likely that Laurentie was offering Hô the job of Governor General of the proposed new Federation of Indochina, the occasion also hardly seems like the encounter of men contemplating - on either side - the impending irretrievable breakdown in relations between the French Republic and Hô's fledgling Democratic Republic of Vietnam. At this point, certainly, the tortoise is well out in front...

Although he was its principal author, Laurentie, for one, had been arguing against the Indochinese federal project within French official circles, at least since the Japanese overthrow of the Vichyste administration of Indochina on 9 March 1945, on the grounds that France had been, in the words of Pierre Messmer, 'physically and intellectually wiped from the face of Vietnam', and that therefore an accommodation needed to be reached with Vietnamese nationalism. ${ }^{17}$ Even earlier, late in 1944, Captain Paul Mus claims to have advised Laurentie to use the term 'French Union', rather than the then preferred 'Communauté, as it would more readily accommodate a sovereign Vietnam. ${ }^{18}$ Returning for a moment to Andrew Smith's objet trouvé, the publicity slip on Mus' 1954 publication Le destin de l'Union française, though the meaning of the inscription 'INDOCHINE X AFRIQUE?' was clear enough in 1954, in the wake of Dien Bien Phu, the message might also be taken as acknowledging a much earlier foreclosing of certain possibilities, though, by the same token, the opening out of others.

Thinking again about Laurentie leads me back to the late colonial state, which is central to an understanding of all three conceptual strands at the heart of the present volume: development, contingency, entanglement. The late colonial state is a curiously elusive entity that did not actually exist at the time, any more than 'decolonization' existed as a generalized concept much before the late 1950s. One of the few historians to write about it at any length is John Darwin, in an incisive article published in $1999 .{ }^{19}$ And yet, in his magisterial The empire project, Darwin prefers to write about colonial governments, for example in the context of an (also fictional) 'fourth British Empire', of which the 'most self-confident face' was the so-called 'second colonial occupation' (that is, the late colonial development regime evoked by Charlotte Riley and Chris Jeppesen). ${ }^{20}$ Looking back at Decolonization and its impact, I realize that I used the colonial state, late or otherwise, largely instrumentally, as the optic through which my 
comparative approach was most effective; a way of bringing the otherwise disproportionate weight of British imperialism into scale with French and other colonial states that I wanted to consider. The onset of the colonial state's 'lateness', which I characterized as a 'late colonial shift' (an idea that appears to have gained some purchase in the literature), seemed to me to be crucial to understanding the ways in which the post-1945 crisis of colonial empire eventually resolved itself into decolonization. And, though others have written about a French 'empire-state' or 'imperial nation-state', in particular Frederick Cooper and Gary Wilder, both of whose work has been immensely influential on my own thinking, it sometimes seems that only my Portuguese colleagues persist with the idea of a late colonial state as such. ${ }^{21}$ Indeed, when Miguel Bandeira Jerónimo invited me in 2012 to present the idea of the British and French late colonial state to a seminar at Brown University, Cooper suggested that it was not that late (as Portuguese late colonialism came later), was not really colonial any more and was certainly not a state - so all I was really left with was 'the'. He was, I think, teasing. Finally, and here I accept mea culpa, though I followed through the late colonial shift to the endgame of decolonization, time, space and flagging momentum ensured that, like late colonialism itself, my work petered out at the moment of 'flag independence'; although reviewers have forborne to mention it, the reference to 'impact' in my title, the vestige of earlier ambition, was no longer fully justified.

Reading the essays collected in this volume has been a pleasurable and intellectually profitable experience, and I was both flattered and slightly unnerved by the invitation to contribute this afterword, by virtue of my status as an 'established scholar' (where 'established' might be taken to mean either superannuated or comprehensively outflanked). I hope I can rise to the challenge with three brief concluding comments to suggest how the essays reflect where we find ourselves in our understanding of the contingencies and entanglements of late colonialism, the late colonial state in particular and the transition to the post-colonial state. First, and starting with a statement of the obvious, all these chapters (apart from Michael Collins' formidable historiographical survey) are written from the perspective of imperial or (soon-to-be) post-imperial actors, and thus reflect, for the period of decolonization, what Cooper has termed 'thinking like an empire'. ${ }^{22}$ In his recent Freedom time, Wilder too takes an approach 'that begins with empire as an optic emphasiz[ing] the real, if problematic ways that colonized peoples were members of imperial political formations', and 'proceeds from the fact that European states did not simply surrender colonies but abandoned their overseas populations'. ${ }^{23}$ As these essays show, this same optic may also embrace the 
'real, if problematic ways' in which those at the imperial centre thought about empire, and how a late imperial perspective conditioned, focused or indeed compromised their thought and action. Imperial, perhaps, but not necessarily imperialist, the voices that emerge from these pages include: officials of a more or less reformist persuasion; recruiters to the Colonial Service seeking to rebrand the career they were offering, as well as their increasingly sceptical recruitees; British Labour Party members and policy-makers wriggling on the hook of their own predilection for late colonial interventionism; oil executives, including those of rival European nations (early-adopting neo-colonialists, perhaps, seeking to profit from impending decolonization); and human rights activists in the English shires, reconciling their concern for individual human rights with the overriding priority of a collective right of self-determination.

Secondly, the essays confirm a view that, if the late colonial state was not perhaps very state-like, it was - or, in the editors' preferred future imperfect tense, would be - becoming more so. (It may be worth recording here that, in French, the conditional is used also for reported speech; as Le Monde might have reported in November 1954: 'Selon M. Mitterrand, l'Algérie, ce serait la France...' In other words, the conditional embraces both point of view and intention.) Just as John Darwin's title draws on Adam Smith's contention that the British empire in 1776 was 'not an empire, but the project of an empire; not a gold mine but the project of a gold mine', ${ }^{24}$ so too we might suggest that the late colonial state was 'the project of a state', but one that never fully got off the ground before decolonization intervened. The postcolonial landscape was strewn with the wreckage of late colonial state projects that failed to make it off the runway - in particular the various federal projects that Collins has studied ${ }^{25}$ as if decolonization were some geopolitical prequel to Ken Annakin's 1965 film Those magnificent men in their flying machines. What all these projects had in common, including those that remained mere blueprints for flying machines, like the plans for a Federation of Indochina, was that, more than the project of a gold/copper/tin/uranium mine, oil well or rubber/ coffee/sisal plantation, they embodied the ambition of what we might call, following Michel Foucault, late colonial rationality or 'governmentality', understood as

the ensemble formed by institutions, procedures, analyses and reflections, calculations, and tactics that allow the exercise of this very specific, albeit very complex, power that has the population as its target, political economy as its major form of knowledge, and apparatuses of security as its essential technical instrument. ${ }^{26}$ 
In seeking to open up analytical space for the idea of an imagined Franco-African federalism, as championed by Léopold Senghor and Aimé Césaire, Wilder urges us to go beyond what he calls 'methodological nationalism' - that is, to see decolonization as something other than 'a series of dyadic encounters between imperial states...figured as powerful nations and [colonized peoples] as not yet independent nations ruled by foreign colonizers'. ${ }^{27}$ This is, at the very least, an interesting mind game, identifying the ways in which our thinking is predicated on 'methodological nationalism', such as my own characterization of the late colonial state, in 2008 , as 'in some sense the prize over which colonial governments and nationalist political forces were fighting', ${ }^{28}$ or indeed David Low and John Lonsdale's highly influential concept of the 'second colonial occupation'. ${ }^{29}$ As my fellow contributors seem to demonstrate, Wilder's suggested alternative approach is the logical corollary of tracing the trajectory of the late (and soon to be defunct) colonial state, whether this comes from the perspective of French proconsuls fretting over the impact of inter-imperial migration or the evolution of the British left's development policy. Even the stratagems of the French official mind to secure a French future for Saharan hydrocarbons, it might be argued, were held in tension with late colonial rationality, whether in the form of de Gaulle's 1958 Constantine Plan for Algerian development, which was to be funded by the Algerian bonanza; or of the Common Organisation of the Saharan Regions (OCRS), which, though one of the least 'state-like' of late colonial projects, was not without appeal to local Tuareg populations who otherwise found themselves at the margins of the future states of Mali and Niger - or indeed to Mali and Niger themselves, which briefly, before Algerian sovereignty dictated otherwise from 1962, glimpsed the possibility of a share of oil revenues. ${ }^{30}$

Thirdly, and most importantly, what emerges from the essays in this collection taken as a whole is a fuller, more complex understanding, but in many ways a more straightforward one than our conventional 'methodological nationalism' allows, of what happened to the late colonial state as it passed through the turbulence of the decolonizing endgame. Reading through Foucault's Security, territory, population lectures (and even while recognizing that Foucault himself would soon take his concept in radically different directions), ${ }^{31}$ I was struck by the parallels between his subject and ours, in his historical account of the evolution in statecraft from the Renaissance to the modern period, from an overriding preoccupation with the maintenance of sovereignty over a given territory, which was associated with Machiavelli's advice to the prince, to a concern with 'people and things', and hence to 'governmentality'. The key relationship, 
it seemed to me, for example in his depiction of the 'Westphalian' state system (from 1648), was the relationship between sovereignty and governmentality (or 'reason of state'). Turning to the late colonial empires, it is this relationship, between an ongoing if challenged imperial sovereignty and the forms of an interventionist, welfarist late colonial state (also a 'security state'), that we address. ${ }^{32}$ The question then arises, which is not considered by Foucault (or indeed by those authors who led me to Foucault, Wilder and Véronique Dimier), ${ }^{33}$ as to what happens (as, Paul Mus argued, had already happened in Vietnam in 1945) when imperial sovereignty is withdrawn. Only a preliminary answer is suggested here, lest this afterword outrun its allotted space, but, on the evidence presented in this volume, it would seem to be the case that the processes of late colonial governmentality simply continued, albeit in a transfigured or transmuted form. Achilles outruns, and possibly even laps, the tortoise, and yet the progress of the tortoise continues. 


\section{Notes}

\section{Introduction}

1 This volume focuses primarily on a comparison between British and French decolonization in Africa, but we are conscious that the Portuguese empire did not decolonize until the 1970s. See Miguel Bandeira Jerónimo and António Costa Pinto (eds.), 'International dimensions of Portuguese late colonialism and decolonization', special issue of Portuguese Studies, 29:2 (2013).

2 Martin Shipway, 'The wind of change and the tides of history: de Gaulle, Macmillan and the beginnings of the French decolonizing endgame', in Larry J. Butler and Sarah Stockwell (eds.), The wind of change: Harold Macmillan and British decolonization (Basingstoke: Palgrave Macmillan, 2013), 180-94.

3 Frederick Cooper, Colonialism in question: theory, knowledge, history (Berkeley, CA: University of California Press, 2005), 22-32.

4 Emma Hunter, Political thought and the public sphere in Tanzania: freedom, democracy and citizenship in the era of decolonization (Cambridge: Cambridge University Press, 2015), 3-4.

5 For a comparative analysis of the political context of European decolonization, see Martin Thomas, Bob Moore and Larry J. Butler, Crises of empire: decolonization and Europe's imperial states, 1918-1975, 2nd edn (London: Bloomsbury, 2015).

6 Frederick Cooper, 'Reconstructing empire in British and French Africa', Past and Present, 210:6 (2011), 196-210.

7 Martin Shipway, Decolonization and its impact: a comparative approach to the end of colonial empire (Malden, MA: Blackwell, 2008), 12-16.

8 Michael Goebel, Anti-imperial metropolis: interwar Paris and the seeds of Third World nationalism (Cambridge: Cambridge University Press, 2015); Susan Pedersen, The guardians: the League of Nations and the crisis of empire (Oxford: Oxford University Press, 2015); Leslie James, George Padmore and decolonization from below: pan-Africanism, the Cold War, and the end of empire (Basingstoke: Palgrave Macmillan, 2015).

9 Sarah Stockwell and Larry J. Butler, 'Introduction', in Butler and Stockwell, The wind of change, $1-19,3-12$.

10 See especially Frederick Cooper, Decolonization and African society: the labor question in French and British Africa (Cambridge: Cambridge University Press, 1996); Todd Shepard, The invention of decolonization: the Algerian War and the remaking of France, 2nd edn (Ithaca, NY: Cornell University Press, 2008); and Elizabeth Buettner, Europe after empire: decolonization, society, and culture (Cambridge: Cambridge University Press, 2016).

11 Els Bogaerts and Remco Raben, Beyond empire and nation: the decolonization of African and Asian societies, 1930s-1960s (Leiden: KITLV Press, 2012), 8-18; Jost Dülffer and Marc Frey (eds.), Elites and decolonization in the twentieth century (Basingstoke: Palgrave Macmillan, 2011), 2.

12 Léopold Senghor, 'La décolonisation', Le Monde, 4 September 1957.

13 Ibid.

14 Frantz Fanon, The wretched of the Earth (London: Penguin Books, 1977); Ngũgĩ wa Thiong'o, Decolonising the mind: the politics of language in African literature (London: Heinemann Educational, 1986); Arjun Appadurai, Modernity at large: cultural dimensions of globalization (Minneapolis, MN: University of Minnesota Press, 1986), especially 89-113.

15 Shipway, Decolonization and its impact, 8. 
16 John Darwin, 'What was the late colonial state?', Itinerario, 23:3/4 (1999), 73-82. See also Miguel Bandeira Jerónimo and António Costa Pinto (eds.), The ends of European colonial empires: cases and comparisons (Basingstoke: Palgrave Macmillan, 2015).

17 Joanna Lewis, Empire state-building: war and welfare in Kenya 1925-52 (Oxford: James Currey, 2001).

18 Martin Thomas, Fight or flight: Britain, France, and their roads from empire (Oxford: Oxford University Press, 2014), x. For an insight into the ways in which British and French colonial administrators deployed similar solutions after the Second World War, despite differing mentalities, see Véronique Dimier, Le gouvernement des colonies, regards croisés francobritanniques (Brussels: Éditions de l'université de Bruxelles, 2004).

19 Tony Hopkins, 'Macmillan's audit of empire, 1957', in Peter Clarke and Clive Trebilcock (eds.), Understanding decline: perceptions and realities of British economic performance (Cambridge: Cambridge University Press, 1997), 234-60; Andrew W. M. Smith, 'Of colonial futures and an administrative Alamo: investment, reform and the loi cadre (1956) in French West Africa', French History, 28:1 (2014), 92-113; Alexander Keese “"Quelques satisfactions d'amour-propre": African elite integration, the Loi-cadre, and involuntary decolonization of French Tropical Africa', Itinerario, 26:1 (2003), 33-57.

20 David Anderson, Histories of the hanged: Britain's dirty war in Kenya and the end of the empire (London: Wiedenfeld \& Nicolson, 2005); Caroline Elkins, Imperial reckoning (London: Henry Holt, 2005); Martin Evans, Algeria: France's undeclared war (Oxford, Oxford University Press 2012); Benjamin Stora, Histoire de la guerre d'Algérie, 1954-1962 (Paris: La Découverte, 2004); Sylvie Thénault, Histoire de la guerre d'indépendance algérienne (Paris: Flammarion, 2005); Sylvie Thénault, Violence ordinaire dans l'Algérie colonial: camps, internements, assignations à residence (Paris: Odile Jacob, 2012); John Iliffe, Africans: the history of a continent, 2nd edn (Cambridge: Cambridge University Press, 2007), 242-44, 253-60.

21 Mark Mazower, No enchanted palace: the end of empire and the ideological origins of the United Nations (Princeton, NJ: Princeton University Press, 2009), 149-89; Samuel Moyn, The last utopia: human rights in history (Cambridge, MA: Belknap Press of Harvard University Press, 2010), 84-119; Odd Arne Westad, The global Cold War: Third World interventions and the making of our times (Cambridge: Cambridge University Press, 2005); Mark Philip Bradley, 'Decolonization, the global South, and the Cold War, 1919-1962', in Melvyn P. Leffler and Odd Arne Westad (eds.), The Cambridge history of the Cold War, vol. I, Origins, 1945-1962 (Cambridge: Cambridge University Press, 2010), 464-85, 470-85; Christopher J. Lee (ed.), Making a world after empire: the Bandung moment and its political afterlives (Athens, $\mathrm{OH}$ : Ohio University Press, 2010).

22 Frederick Cooper, Citizenship between empire and nation: remaking France and French Africa, 1945-1960 (Princeton, NJ: Princeton University Press, 2014); John Darwin, The empire project: the rise and fall of the British world-system 1830-1970 (Cambridge: Cambridge University Press, 2009), 610.

23 Frederick Cooper, 'Possibility and constraint: African independence in historical perspective', Journal of African History, 49:2 (2008), 167-96, 172.

24 Buettner, Europe after empire, 5-8.

25 Gary Wilder, The French imperial nation-state: negritude and colonial humanism between the two world wars (Chicago, IL: University of Chicago Press, 2005), 3-23.

26 This is outlined well in an excellent essay by Simon Potter and Jonathan Saha, 'Global history, imperial history and connected histories of empire', Journal of Colonialism and Colonial History, 16:1 (2015), www.muse.jhu.edu/article/577738.

27 Cooper, 'Reconstructing empire', 196.

28 On the breakdown of European empires in Asia, see Christopher A. Bayly and Tim Harper, Forgotten armies: the fall of British Asia, 1941-45 (London: Allen Lane, 2004); and Christopher A. Bayly and Tim Harper, Forgotten wars: the end of Britain's Asian empire (London: Allen Lane, 2007). On the impact of the war on returning African troops, see David Killingray, Fighting for Britain: African soldiers in the Second World War (Woodbridge: James Currey, 2010), 203-35; and Gregory Mann, Native sons: West African veterans and France in the twentieth century (Durham, NC: Duke University Press, 2006), 108-45.

29 Erez Manela, The Wilsonian moment: self-determination and the international origins of anticolonial nationalism (Oxford: Oxford University Press, 2007); on interwar colonial repression, see Martin Thomas, Violence and colonial order: police, workers and protest in the European colonial empires, 1918-1940 (Cambridge: Cambridge University Press, 2012). 
30 Hunter, Political thought and the public sphere, 66.

31 Monica M. van Beusekom, Negotiating development: African farmers and colonial experts at the Office du Niger, 1920-1960 (Oxford: Heinemann, 2002), xix-xx; Joseph Morgan Hodge, Triumph of the expert: agrarian doctrines of development and the legacies of British colonialism (Athens, OH: Ohio University Press, 2007); Elise Huillery, 'The black man's burden: the cost of colonization of French West Africa', Journal of Economic History, 74:1 (2014), 1-38; Véronique Dimier, The invention of a European development aid bureaucracy: recycling empire (Basingstoke: Palgrave Macmillan, 2014); Gareth Austin, 'African economic development and colonial legacies', Revue internationale de politique de développement, 1:1 (2010), 11-32; Sandrine Kott, 'Une “communauté épistémique” du social?', Genèses, 71: 2 (2008), 26-46.

32 Frederick Cooper and Randall Packard (eds.), International development and the social sciences: essays on the history and politics of knowledge (Berkeley, CA: University of California Press, 1997), 2-28.

33 Leslie James and Elisabeth Leake (eds.), Decolonization and the Cold War (London: Bloomsbury, 2015), especially 2-8; Robert J. McMahon (ed.), The Cold War in the Third World (Oxford: Oxford University Press, 2013); Matthew Connelly, 'Taking off the Cold War lens: visions of North-South conflict during the Algerian war for independence', American Historical Review, 105:3 (2000), 739-69.

34 Tania Murray Li, The will to improve: governmentality, development, and the practice of politics (Durham, NC: Duke University Press, 2007), 10-18.

35 Frederick Cooper, Africa since 1940: the past of the present (Cambridge: Cambridge University Press, 2002), 20-37.

36 Joseph Morgan Hodge, 'Writing the history of development (part 2: longer, deeper, wider)', Humanity: An International Journal of Human Rights, Humanitarianism, and Development, 7:1 (2016), 125-74, 138-42.

37 Senghor, 'La décolonisation'.

38 Daniel Branch, Defeating Mau Mau, creating Kenya: counterinsurgency, civil war, and decolonization (Cambridge: Cambridge University Press, 2009); Fabian Klose, Human rights in the shadow of colonial violence: the wars of independence in Kenya and Algeria (Philadelphia, PA: University of Pennsylvania Press, 2013).

39 Jane Burbank and Frederick Cooper, Empires in world history: power and the politics of difference (Princeton, NJ: Princeton University Press, 2011), 16-17, 420-9.

40 Joanna Lewis, "Tropical East Ends" and the Second World War: some contradictions in Colonial Office welfare initiatives', Journal of Imperial and Commonwealth History, 28:2 (2000), 42-66; Kate Skinner, 'Who knew the minds of the people? Specialist knowledge and developmentalist authoritarianism in postcolonial Ghana', Journal of Imperial and Commonwealth History, 39:2 (2011), 297-323, 300; Emma Hunter, 'Dutiful subjects, patriotic citizens and the concept of good citizenship in twentieth-century Tanzania', Historical Journal, $56: 1$ (2013), 257-77.

41 Daniel Maul, Human rights, development and decolonization: the International Labour Organization, 1940-70 (Basingstoke: Palgrave Macmillan, 2012), 4-7.

42 Cooper, Citizenship, passim.

43 Rohland Schuknecht, British colonial development policy after the Second World War: the case of Sukumaland, Tanganyika (Munster: LIT Verlag, 2010), 23-32.

44 In particular, this can be seen in the 'Eurafrican' project explored by the French government as a means of reconciling its African presence with European integration. See Peo Hansen and Stefan Jonsson, Eurafrica: the untold history of European integration and colonialism (London: Bloomsbury, 2014); and Adekeye Adebajo and Kaye Whiteman (eds.), The EU and Africa: from Eurafrique to Afro-Europa (London: Hurst, 2012).

45 Gary Wilder, Freedom time: negritude, decolonization, and the future of the world (Durham, NC: Duke University Press, 2014), 1-16.

46 Michael Adas, Machines as the measure of men: science, technology, and ideologies of Western dominance (Ithaca, NY: Cornell University Press, 1989), 241-58.

47 This is very well explored in Butler and Stockwell, The wind of change. Todd Shepard in particular has highlighted the way in which this battle took place in popular discourse, in The invention of decolonization, and illustrated the process taking place in the document series he authored, Voices of decolonization: a brief history with documents (Boston, MA: Bedford/St Martins, 2015). On the British side, Ronald Hyam discusses the official mind in Britain and its attempts 
to control these timetables in Britain's declining empire: the road to decolonisation 19181968 (Cambridge: Cambridge University Press, 2006), especially chapter 4. This analysis of the British official mind is further developed in the document series edited by Ronald Hyam and William Roger Louis, British documents on the end of empire, vol. IV, The Conservative government and the end of empire 1957-1964 (London: Stationery Office, 2000).

48 Shipway, Decolonization and its impact, 2.

49 Georges Perec, 'Think/classify', in Species of spaces and other pieces (London: Penguin Books, 1999), 188-206, 188; Antoinette Burton, Archive stories: facts, fictions, and the writing of history (Durham, NC: Duke University Press, 2006), 3-11.

50 Reinhart Koselleck, 'Crisis', Journal of the History of Ideas, 67:2 (2006), 357-400, 371-2.

51 Michael Collins, 'Decolonization and the "federal moment"', Diplomacy and Statecraft, 24:1 (2013), 21-40, 35.

52 Reinhart Koselleck, Futures past: on the semantics of historical time (New York, NY: Columbia University Press, 2004), 255-76.

53 Andrew W. M. Smith, 'African dawn: Keïta Fodéba and the imagining of national culture in Guinea', Historical Reflections/Réflexions historiques (in press, 2017). For another example, see the story of Vlado Clementis' hat in Milan Kundera, The book of laughter and forgetting (London: Penguin Books, 1983), 3.

54 This is true also of the story of activists told by Kristin Ross, in which revisions altered the memory of the events of 1968: May '68 and its afterlives (Chicago, IL: University of Chicago Press, 2002).

55 Ann Laura Stoler, Along the archival grain: epistemic anxieties and colonial common sense (Princeton, NJ: Princeton University Press, 2010), 3.

56 See, for example, the discussions around the establishment of the Mali Federation in Alexander Keese, 'French officials and the insecurities of change in sub-Saharan Africa: Dakar, 19th August 1960 revisited', in Tony Chafer and Alexander Keese (eds.), Francophone Africa at fifty (Manchester: Manchester University Press, 2013), 44-57.

57 Sarah Stockwell, The business of decolonization: British business strategies in the Gold Coast (Oxford: Oxford University Press, 2000); Gregory Mann, From empires to NGOs in the West African Sahel: the road to nongovernmentality (Cambridge: Cambridge University Press, 2014), 1-11; Joseph Morgan Hodge, 'British colonial expertise, postcolonial careering and the early history of international development', Journal of Modern European History, 8:1 (2010), 24-46. See also Toyin Falola and Emmanuel M. Mbah (eds.), Contemporary Africa: challenges and opportunities (Basingstoke: Palgrave Macmillan, 2014).

58 This is a key theme in the edited collection Francophone Africa at fifty, and is well outlined in the 'Introduction' (Tony Chafer and Alexander Keese, 1-12) and in the chapters in part III of the volume, 'Continuities and connections'. See also Ashley Jackson, 'Empire and beyond: the pursuit of overseas national interests in the late twentieth century', English Historical Review, 123:499 (2007), 1350-66.

59 Robert J. C. Young, Empire, colony, postcolony (Chichester: Wiley-Blackwell, 2015).

60 On the need to break beyond the binary of metropole and periphery, see Ann Laura Stoler and Frederick Cooper, 'Between metropole and colony: rethinking a research agenda', in Ann Laura Stoler and Frederick Cooper (eds.), Tensions of empire: colonial cultures in a bourgeois world (Berkeley, CA: University of California Press, 1997), 1-58. See also Buettner, Europe after empire; Jordanna Bailkin, The afterlife of empire (Berkeley, CA: University of California Press, 2012); and Herman Lebovics, Bringing the empire back home: France in the global age (Durham, NC: Duke University Press, 2004).

61 Shepard, The invention of decolonization, 10-15.

62 For example, Christopher A. Bayly, The birth of the modern world, 1780-1914: global connections and comparisons (London: Wiley-Blackwell, 2004); Tony Ballantyne and Antoinette Burton, Empires and the reach of the global (Cambridge, MA: Harvard University Press, 2014).

63 Sebastian Conrad, 'Rethinking German colonialism in a global age', Journal of Imperial and Commonwealth History, 41:4 (2013), 543-66, 551.

64 David Lambert and Alan Lester (eds.), Colonial lives across the British Empire: imperial careering in the long nineteenth century (Cambridge: Cambridge University Press, 2006), 1-31.

65 Martin Thomas and Andrew Thompson, "Empire and globalisation: from "high imperialism" to decolonization', International History Review, 36:1 (2014), 142-70; Tony Hopkins, 'Rethinking decolonization', Past and Present, 200 (2008), 211-47.

66 Potter and Saha, 'Global history'. 


\section{Chapter 1}

1 David Scott's reflections on the opportunities and constraints of a given moment of decolonization are pertinent here: see his Refashioning futures: criticism after postcoloniality (Princeton, NJ: Princeton University Press, 1999); and 'Norms of self-determination: thinking sovereignty through', Middle East Law and Governance, 4:2/3 (2012), 195-224. For a particular exploration of the determining effects of the timing of decolonization and in a French imperial context, see Gary Wilder, Freedom time: negritude, decolonization and the future of the world (Durham, NC: Duke University Press, 2015).

2 In the British case, such perspectives connect work stretching from John Robert Seeley's The expansion of England: two courses of lectures (London: Macmillan, 1883) through to the eight volume Cambridge history of the British empire (1929-61) and beyond to the post-war work of historians such as Nicholas Mansergh. The first volume of The Cambridge history speaks of a 'long story of colonization and imperial policy, of the rise and growth of new nations and the assumption of vast responsibilities, a story varied in its scene, but finding its unity in the activities of a maritime and commercial people': John Holland Rose, Arthur Percival Newton and Ernest Alfred Benians, The Cambridge history of the British empire, vol. I, The old empire from the beginnings to 1783 (New York, NY: Macmillan, 1929), v.

3 Sir Hilton Poynton, the last permanent undersecretary at the British Colonial Office, claims the term 'decolonization' was never used in official circles. See his Africa in the colonial period: the colonial administrator in the age of decolonization (Oxford: Committee for African Studies, 1978), referenced in Anthony Kirk-Greene, 'Decolonisation in British Africa', History Today, 42:1 (1992), www.historytoday.com/anthony-greene/decolonisation-british-africa (accessed 17 December 2015). For a helpful discussion of the origins of the term in academic discourse, see Todd Shepard, The invention of decolonization: the Algerian war and the remaking of France (Ithaca, NY: Cornell University Press, 2006), 56. For a nuanced discussion of African nationalism in the interwar period, see Lord Hailey, 'Nationalism in Africa', Journal of the Royal African Society, 36:143 (1937), 134-47. Hailey concludes that, when it comes to nationalism in Africa, 'at the moment the tangible signs of such a movement are at least not spectacular; and the obstacles to their growth are great'.

4 The confidence of the authors of the Cambridge history, for example, is manifest in their belief that the 'time has not yet come when that story can be finally written', because the 'British Empire is still in the long process of its growth': Rose et al., The Cambridge history, vol. I, v.

5 These basic beliefs were broadly shared by a whole generation of interwar historians of British imperialism. See Lionel Curtis (ed.), The commonwealth of nations: an inquiry into the nature of citizenship in the British empire, and into the mutual relations of the several communities thereof (London: Macmillan, 1916); Lionel Curtis, Dyarchy (Oxford: Oxford University Press, 1920); Kenneth Clinton Wheare, The Statute of Westminster and dominion status (Oxford: Clarendon Press, 1938); Reginald Coupland, East Africa and its invaders: from the earliest times to the death of Seyyid Said in 1856 (Oxford: Clarendon Press, 1938); and William Keith Hancock, Survey of British Commonwealth affairs, 2 vols. (Oxford: Oxford University Press, 1942). It extended well beyond the Second World War, too, in the work of men such as Nicholas Mansergh and Max Beloff. See, for example, Nicholas Mansergh, The Commonwealth experience: from British to multiracial Commonwealth (London: Weidenfeld \& Nicholson, 1969), as well as his epic twelve-volume series of books on India, The Transfer of Power 1942-7 (London: Stationery Office), published in the 1970s. See also Max Beloff, Imperial sunset: dream of Commonwealth, 1921-42 (London: Macmillan, 1989).

6 William Keith Hancock, Argument of empire (London: Penguin Books, 1943), 12. As William Roger Louis has commented, 'Historians of the interwar years, with varying degrees of scepticism, continued to affirm the Whig idea of progress': William Roger Louis, 'Introduction', in Robin W. Winks (ed.), The Oxford history of the British empire, vol. V, Historiography (Oxford: Oxford University Press, 1999), 1-42, 27. Louis adds that it 'would do them an injustice to measure them against the Zeitgeist of a later age'. In an important sense he is right. Even though by the 1950s there was a growing political and academic awareness that British control of the development of its empire/commonwealth was increasingly impractical, in Africa specifically, both British and French officials still believed - as discussed below - that they were in charge of the continent's direction after 1945. 
7 CO 847/20/47139 at folio 1, and CO 323/1868 Pt II/9057 1A, quoted in John Flint, 'Planned decolonization and its failure in British Africa', African Affairs, 82:328 (1983), 389-411, 398.

8 The best work on imperial ideologies and the British left remains Stephen Howe, Anticolonialism in British politics: the left and the end of empire, 1918-1964 (Oxford: Clarendon Press, 1993). On the Conservative Party, see Philip Murphy, Party politics and decolonization: the Conservative Party and British colonial policy in tropical Africa, 1951-1964 (Oxford: Oxford University Press, 1995); and the essays in Larry J. Butler and Sarah Stockwell (eds.), The wind of change: Harold Macmillan and British decolonization (Basingstoke: Palgrave Macmillan, 2013).

9 Useful assessments of British politics during this period include David Goldsworthy, Colonial issues in British politics, 1945-1961: from 'colonial development' to the 'wind of change' (Oxford: Oxford University Press, 1971); and Murphy, Party politics and decolonization. For a comparative analysis of the imperial dimension in domestic politics, see Miles Kahler, Decolonization in Britain and France: the domestic consequences of international relations (Princeton, NJ: Princeton University Press, 1984). Re-evaluations are found in Martin Lynn (ed.), The British empire in the 1950s: retreat or revival? (Basingstoke: Palgrave Macmillan, 2006).

10 The 'transfer of power' had cross-party appeal, particularly in early attempts to explain postwar decolonization written by those involved in the process themselves. Harold Macmillan's memoirs, especially his Pointing the way, 1959-61 (London: Macmillan, 1972), can be seen as a last breath for the idea that decolonization was an intended affair, leading to a mutually beneficial postcolonial relationship within the Commonwealth. Although it had been shared at an earlier stage, this kind of sentimentalism had been severely eroded among Labour politicians by their experience of Commonwealth relations in the later 1960s, particularly by the Rhodesian and Biafran crises.

11 John W. Cell, 'On the eve of decolonization: the Colonial Office's plans for the transfer of power in Africa, 1947', Journal of Imperial and Commonwealth History, 8:3 (1980), 235-57, 235.

12 Robinson writes in highly favourable terms of Cohen and the "new guard of "democratizers" appointed after 1947', who would 'assemble at the drumhead of the archetypal anti-Lugard Andrew Cohen'. Ronald Robinson, 'Sir Andrew Cohen: proconsul of African nationalism', in Lewis H. Gann and Peter Duignan (eds.), African proconsuls: European governors in Africa (New York, NY: Free Press, 1978), 353-64, 353, 363 fn 2. Robinson has far less to say about Cohen's later role in pushing for the creation of the Central African Federation in 1951 during the final months of the second Attlee administration, or Cohen's decision to exile Kabaka Mutesa II from Uganda in 1953 - both actions that put Cohen in a rather more ambiguous relationship vis-à-vis African nationalism than Robinson allows for.

13 A stimulating discussion of the long intellectual history of Britain's civilizing mission can be found in Ali Parchami, Hegemonic peace and empire: the Pax Romana, Britannica, and Americana (London: Routledge, 2009). See also Julian Go, Patterns of empire: the British and American empires, 1688 to the present (Cambridge: Cambridge University Press, 2011).

14 The literature on Labour's post-war administration and the empire is now very large. For recent work relevant to this discussion, see Paul Kelemen, 'Modernising colonialism: the British Labour movement and Africa', Journal of Imperial and Commonwealth History, 34:2 (2006), 223-44. For a broader perspective on colonial development, see Charlotte Lydia Riley, Monstrous predatory vampires and beneficent fairy-godmothers: British post-war colonial development in Africa, unpublished $\mathrm{PhD}$ thesis, University College London, 2013. On the Central African Federation, see Ronald Hyam, 'The political consequences of Seretse Khama', Historical Journal, 29:4 (1986), 921-47; Ronald Hyam, 'The geopolitical origins of the Central African Federation: Britain, Rhodesia and South Africa, 1948-1953', Historical Journal, 30:1 (1987), 145-72; Philip Murphy, “"Government by blackmail”: the origins of the Central African Federation reconsidered', in Lynn, The British empire in the 1950s, 53-78; and Michael Collins, 'Decolonization and the "federal moment"', Diplomacy and Statecraft, 24:1 (2013), 21-40.

15 Martin Thomas, Bob Moore and Larry J. Butler, Crises of empire: decolonization and Europe's imperial states, 1918-1975, 2nd edn (London: Bloomsbury, 2015), 137. For a comprehensive and thoughtful exploration of this French mentality, see Tony Chafer, The end of empire in French West Africa: France's successful decolonization? (Oxford: Berg, 2002). See also Catherine Coquery-Vidrovitch and Odile Goerg (eds.), L'Afrique Occidentale au temps des français: colonisateurs et colonisés, c. 1860-1960 (Paris: La Découverte, 1992); and Charles Becker, Saliou Mbaye and Ibrahima Thioub (eds.), AOF: Réalités et héritages: sociétés Ouest-Africaines et ordre colonial, 1895-1960, 2 vols. (Dakar: Direction des Archives nationales du Sénégal, 1997). 
16 Quoted in Martin Shipway, 'Madagascar on the eve of insurrection, 1944-1947: the impasse of a liberal colonial policy', Journal of Imperial and Commonwealth History, 24:1 (1996), 72-100, 94.

17 Henri Brunschwig, Mythes et réalités de colonialisme français, 1871-1914 (Paris: Armand Colin, 1960), 174.

18 See, for example, Mathew Burrows, "Mission civilisatrice": French cultural policy in the Middle East, 1860-1914', Historical Journal, 29:1 (1986), 109-35. See also Jacques Marseille, 'La gauche, la droite et la fait colonial en France: des années 1880 aux années 1960', Vingtième siècle: révue d'histoire, 24:1 (1989), 17-28.

19 Alice L. Conklin, A mission to civilize: the republican idea of empire in France and West Africa, 1895-1930 (Stanford, CA: Stanford University Press, 1997); see also Gordon Cumming, 'Transporting the "republican" model? A critical appraisal of France's historic mission in Africa', Journal of Contemporary African Studies, 23:2 (2005), 233-53; and Raymond F. Betts, Assimilation and association in French colonial theory, 1890-1914 (New York, NY: Columbia University Press, 1961).

20 See, for example, James Patrick Daughton, An empire divided: religion, republicanism, and the making of French colonialism (Oxford: Oxford University Press, 2006); James Patrick Daughton and Owen White, In God's empire: French missionaries in the modern world (Oxford: Oxford University Press, 2011); Sarah A. Curtis, Civilizing habits: women missionaries and the revival of French empire (Oxford: Oxford University Press, 2010); and Bertrand Taithe, 'Algerian orphans and colonial Christianity in Algeria, 1866-1939', French History, 20:4 (2006), 252 53. It is worth noting that Christianity was not the only motivating belief: Lisa Moses Leff, 'Jews, liberals and the civilizing mission in nineteenth-century France', Historical Reflections/ Réflexions historiques, 32:1 (2006), 105-28.

21 On the extent to which education policy (and the spectre of the civilizing mission) represented an attempt to limit dynamism among elites, see Peggy R. Sabatier, "Elite" education in French West Africa: the era of limits, 1903-1945', International Journal of African Historical Studies, 11:2 (1978), 247-66; Tony Chafer, 'Education and political socialisation of a national-colonial political elite in French West Africa, 1936-47', Journal of Imperial and Commonwealth History, 35:3 (2007), 437-58; and Herman Lebovics, True France: the wars over cultural identity, 1900 1945 (Ithaca, NY: Cornell University Press, 1992), 110-19. This assimilationist debate is well explored in a comparative colonial perspective in Alexander Keese, Living with ambiguity: integrating an African elite in French and Portuguese Africa, 1930-61 (Stuttgart: Franz Steiner, 2007).

22 Gary Wilder, The French imperial nation state: negritude and colonial humanism between the two world wars (Chicago, IL: Chicago University Press, 2005). See also Patricia Lorcin, Imperial identities: stereotyping, prejudice, and race in colonial Algeria (London: I. B. Tauris, 1995); and Elizabeth Ezra, The colonial unconscious: race and culture in interwar France (Ithaca, NY: Cornell University Press, 2000).

23 See Raoul Girardet, L'idée colonial en France (Paris: Hachette, 2005); Pascal Blanchard and Sandrine Lemaire (eds.), Culture impériale 1931-1961: les colonies au coeur de la République (Paris: Autrement, 2004); and Jean-Pierre Biondi and Gilles Morin, Les anticolonialistes (1881-1962) (Paris: Hachette, 1992). The underpinning logic of the civilizing mission is likewise skewered in polemical fashion in Emmanuel Saint-Martin and Romain Gubert, L'Arrogance française (Paris: Jacob Duvernet, 2003), and the besoin de rayonnement is disentangled in context in Tony Chafer, 'French African policy in historical perspective', Journal of Contemporary African Studies, 19:2 (2001), 165-82. For a polemical response in the wake of the terrorist attack on the offices of Charlie Hebdo, see Michael Collins, 'The response to Charlie Hebdo and the imperial hangover in France', History Vault, 21 January 2015, www. thehistoryvault.co.uk/the-response-to-charlie-hebdo-and-the-imperial-hangover-in-france (accessed 17 December 2015).

24 Itay Lotem, 'A decade after the riots, France has rewritten its colonial history', The Conversation, 25 January 2016, http://theconversation.com/a-decade-after-the-riots-france-has-rewrittenits-colonial-history-50499 (accessed 31 January 2016).

25 This has been explored in the forceful polemic by Emmanuel Todd, Who is Charlie? Xenophobia and the new middle class (Cambridge: Polity, 2015), in which the author questions the racial dimensions of the Republic's allegedly inconsistent commitment to equality. For a cogently argued and circumspect history of the changes undergone by the republican model in the wake 
of decolonization, see Emile Chabal, A divided republic: nation, state and citizenship in contemporary France (Cambridge: Cambridge University Press, 2015), especially ch. 3.

26 Alan Lester, 'Time to throw out the balance sheet approach', Snapshots of empire: University of Sussex, 26 January 2016, https://blogs.sussex.ac.uk/snapshotsofempire/2016/01/26/timeto-throw-out-the-balance-sheet (accessed 31 January 2016).

27 David Anderson, Histories of the hanged: Britain's dirty war in Kenya and the end of the empire (London: Weidenfeld \& Nicholson, 2006); Huw Bennett, Fighting the Mau Mau: the British army and counter-insurgency in the Kenya emergency (Cambridge: Cambridge University Press, 2012); Caroline Elkins, Imperial reckoning (London: Henry Holt, 2005); Frank Furedi, 'Creating a breathing space: the political management of colonial emergencies', Journal of Imperial and Commonwealth History, 21:3 (1993), 89-106; Benjamin Grob-Fitzgibbon, Imperial endgame: Britain's dirty wars and the end of empire (Basingstoke: Palgrave Macmillan, 2011); Calder Walton, Empire of secrets: British intelligence, the Cold War and the twilight of empire (London: Harper, 2013). On the Mau Mau Veterans Association case against the British government, as well as the Hanslope Park 'migrated' archives, see David Anderson, "Mau Mau in the High Court and the "lost" British empire archives: colonial conspiracy or bureaucratic bungle?', Journal of Imperial and Commonwealth History, 39:5 (2011), 699-716; and the Al Jazeera Witness documentary by Jemma Gander, 'The last battle', broadcast on 23 May 2013, www.aljazeera.com/programmes/witness/2013/05/201352110394421881. html (accessed 14 August 2015). With regard to the archives themselves, see Anthony Cary, 'Cary report on the release of the colonial administration files', Foreign and Commonwealth Office, 24 February 2011, www.gov.uk/government/publications/cary-report-on-release-ofthe-colonial-administration-files (accessed 10 August 2015). Much of the so-called migrated archive is now available at the UK National Archives, London, under record group FCO141.

28 Niall Ferguson is generally seen as the leading voice in the 'for' camp, extolling the overall positive effect of British imperialism in making the 'modern world'. See his Empire: how Britain made the modern world (London: Penguin Books, 2003). A sympathetic hearing (with accompanying TV series) was produced by the notable British broadcaster Jeremy Paxman under the title Empire: what ruling the world did to the British (London: Viking, 2012). A more critical account, but still in line with Ferguson and Paxman's Eurocentric perspectives, is given by Kwasi Kwarteng, Ghosts of empire: Britain's legacies in the modern world (London: Bloomsbury, 2012). Richard Gott's Britain's empire: resistance, repression and revolt (London: Verso, 2011) meticulously catalogues colonial violence, as well as the many stories of its victims and those who stood up to colonial rule. In this sense it offers a welcome shift of emphasis away from Britain as the centre of its narrative, but overall its approach and tone add to the arguably oversimplified dichotomy of good empire, bad empire. Another popular history of empire's decline, Piers Brendon's The decline and fall of the British empire, 1781-1997 (London: Jonathan Cape, 2007), is a 'warts and all' version but, as one reviewer pointed out, by portraying 'a glittering panoply of decadence, folly, farce and devastation' it leaves the reader wondering 'how Britain ever managed to have an empire at all': Maya Jasanoff, 'Last post for the oddball empire', The Guardian, 20 October 2007, www.theguardian.com/books/2007/oct/20/featuresreviews. guardianreview2 (accessed 14 January 2016).

29 A July 2014 YouGov opinion poll in the United Kingdom found that 49 per cent of respondents believed that countries formerly colonized by Britain were 'better off for it'. A January 2016 poll found that 44 per cent of British people believed that they should be 'proud of British colonialism': Will Dahlgreen, 'Rhodes must not fall', YouGov, 18 January 2016, https:// yougov.co.uk/news/2016/01/18/rhodes-must-not-fall (accessed 21 January 2016).

30 John Darwin's suggestion that after 1960 a 'great reaction set in', whereby, to 'progressive opinion in Britain, the imperial tradition now seemed an incubus', may not capture the full story: John Darwin, Unfinished empire: the global expansion of Britain (London: Penguin Books, 2012), 3.

31 For an unambiguous statement on the importance of the official archive, see Flint, 'Planned decolonization and its failure in British Africa', 389: 'My sources will be, almost entirely, the Colonial Office files for the period after 1938. I make no apologies for this, because the dynamic for change, before 1946 at the earliest, lay there, and not in Africa.'

32 As Darwin has put it, 'the ideas and arguments found there [in 'The imperialism of free trade'] bear almost constant re-reading': John Darwin, The empire project: the rise and fall of the British world-system 1830-1970 (Cambridge: Cambridge University Press, 2009), 793. 
332015 saw not one but two detailed examinations of Darwin's work in the scholarly journals. The first was a surprisingly personal, interrogative analysis of Darwin's attitudes to the study of the imperial past through the wider corpus of Darwin's work and his intellectual influences by Bill Schwarz: 'Unsentimental education: John Darwin's empire', Journal of Imperial and Commonwealth History, 43:1 (2015), 125-44. The second was a roundtable on Darwin's major book The Empire Project entitled 'Imperial history by the book: a roundtable on John Darwin's The Empire Project' and coordinated by Antoinette Burton for the Journal of British Studies, 54:4 (2015), 971-97, which contained pointed remarks about Darwin's style of scholarship, not to mention the size of his books, from Burton. Not to be displaced as the main object of the postcolonial historians' wrath, Bernard Porter has issued a new provocation in the form of British imperial: what the empire wasn't (London: I. B. Tauris, 2016). It is hard to imagine it will attract the same level of interest as that generated by his Absent-minded imperialists: empire, society and culture in Britain (Oxford: Oxford University Press, 2004), since the better parts of the new book appear to be a more concise reiteration of the previous one.

34 John Darwin, 'Gallagher's empire', in William Roger Louis (ed.), Yet more adventures with Britannia: personalities, politics and culture in Britain (London: I. B. Tauris, 2005), 235-50, 236.

35 Schwarz, 'Unsentimental education', 126.

36 John Darwin, 'Was there a fourth British empire?', in Lynn, The British empire in the 1950s, 16-31; John Darwin, 'What was the late colonial state?' Itinerario, 23:3 (1999), 73-82.

37 'Singapore's fall was the brutal proof that the Eurasian revolution of the 1930s and 1940s had reached its climax. The global preconditions in which the British world-system had been continuously viable since the 1830 s and 1840 s, had all but disappeared in the storms of war. The European balance, precariously restored after 1918, had been comprehensively wrecked... "Passive" East Asia had become an uncontrollable vortex of anti-Western imperialism.' Darwin, The empire project, 513.

38 For the 'world island', see Halford John Mackinder, 'The geographical pivot of history', Geographical Journal, 23:4 (1904), 421-37. On the scope of Darwin's analytical canvas, see Alan Lester, 'Comment: geo-strategy (and violence) in the making of the modern world', in the aforementioned roundtable, Journal of British Studies, 54:4 (2015), 977-83.

39 The empire project is built on an immense amount of archival work in the United Kingdom, the Irish Republic, South Africa, Canada, Australia, New Zealand and the United States, but includes no original primary source work in African archives other than South Africa, and relatively little material narrating perspectives from colonized peoples, excluding even nationalist elites.

40 For a broad discussion, see Richard Drayton, 'Where does the world historian write from? Objectivity, moral conscience and the past and present of imperialism', Journal of Contemporary History, 46:3 (2011), 671-85. In fundamental ways these ideas constitute the nexus between history and present politics. For an excellent review of this, see Dane Kennedy, 'The imperial history wars', Journal of British Studies, 54:1 (2015), 5-22.

41 When the Indian National Congress was formed in Mumbai in 1885, its purpose was not to fulfil nationalist ideology - for every nation, its own state - but broadly to petition the imperial power to give more consideration to the interest of Indians and India as a political and economic entity. See, for example, Dadabhai Naoroji, Poverty and un-British rule in India (London: Swan Sonnenschein, 1901).

42 This came alongside a turn to area studies within social science and humanities departments in many European and North American universities that also threatened the status of imperial history. See David K. Fieldhouse, 'Can Humpty-Dumpty be put together again? Imperial history in the 1980s', Journal of Imperial and Commonwealth History, 12:2 (1984), 9-23.

43 It is worth noting that there were histories written at a much earlier time that could be deemed as Africanist, or that sought to define the shape of an African 'nation'. Apolo Kagwa, the Buganda Katikkiro (prime minister) from 1890 to 1926 (first under Mwanga II and later Daudi Chwa), travelled to England with his secretary Ham Mukasa in 1902 for the coronation of Edward VII. He did much to promote the distinctive history of Buganda (which would impact upon subsequent colonial politics in the Uganda Protectorate) through his ethnography of Buganda and the publication of Basekabaka be Buganda in English as The Kings of Buganda (London: Macmillan, 1901).

44 K. Onwuka Dike, Trade and politics in the Niger Delta: an introduction to the economic and political history of Nigeria (Oxford: Clarendon Press, 1956). For an overview of this development, see Terence Ranger, Emerging themes of African historiography (Nairobi: East African Publishing 
House, 1968). Dike's influence can be seen in the work of eminent African historians writing today: see, for example, Toyin Falola, The history of Nigeria (Westport, CT: Greenwood Press, 1999).

45 Roland Oliver, The missionary factor in East Africa (London: Longmans, 1952); Roland Oliver, Sir Harry Johnston and the scramble for Africa (London: Chatto \& Windus, 1957); Roland Oliver and John D. Fage, A short history of Africa (London: Penguin Books, 1962); Roland Oliver and Gervase Mathew (eds.), History of East Africa, vol. I (Oxford: Clarendon Press, 1963).

46 Immanuel Wallerstein's Africa: the politics of independence and unity (Lincoln, NE: University of Nebraska Press, 2005) is a useful single-volume version including Wallerstein's sequel Africa: the politics of unity (New York, NY: Random House, 1967). Basil Davidson was a popularizer of African history and had a counterpart in France, Jean Suret-Canale. Institutional dimensions were important too. In London, SOAS pushed forward the teaching and research of African history. The Journal of African History and the Cahiers d'études africaines were both set up in 1960. In 1963 UNESCO approved the Organisation of African Unity proposal for a new African-centred General History of Africa.

47 D. A. Low, Alison Smith and John Lonsdale can be seen as pioneers of new work published in the 1970s on the history of Africa that sought to balance both African and metropolitan perspectives. See, for example, the third volume of the Oxford History of East Africa - D. A. Low and Alison Smith (eds.), History of East Africa, vol. III (Oxford: Clarendon Press, 1976) - particularly the important introductory essay: D. A. Low and John Lonsdale, 'Introduction: towards the new order, 1945-1963', in Low and Smith, History of East Africa, vol. III, 1-63. By the 1980s work explicitly on the history of decolonization can be seen as heavily marked by these transformations. Two major volumes covering decolonization in formerly British and French Africa - edited by Prosser Gifford and William Roger Louis and published in 1982 - are indicative of the changes that had taken place. Louis was heavily influenced by the older perspectives of Robinson and Gallagher, yet Prosser Gifford and William Roger Louis (eds.), The transfer of power in Africa: decolonization, 1940-1960 (New Haven, CT: Yale University Press, 1982) and Decolonization and African independence: the transfers of power, 1960-1980 (New Haven, CT: Yale University Press, 1988), include essays from a very wide range of scholars. Some are advocates of a 'peripheral' theory still dealing largely with metropolitan sources and actors, while others are specialists in the decolonization of particular countries or regions, working in African archives, and many of them Africans rather than Europeans. Scholars such as John Hargreaves, John Lonsdale and John Iliffe have carried on this trend from the 1970 s to the present. John Hargreaves' Decolonization in Africa (London: Longman, 1996) is widely and rightly respected for its detailed engagement with African political agency. See also Bruce Berman and John Lonsdale, Unhappy valley: conflict in Kenya and Africa (Oxford: James Currey, 1992); and John Iliffe, Africans: the history of a continent (Cambridge: Cambridge University Press, 2007).

48 Henri Grimal, Decolonization: the British, French, Dutch and Belgian empires, 1919-1963 (London: Routledge, 1978). Similar ideas underpin the later work of John Gallagher, who extended his analysis of peripheral politics and collaboration in Decline, revival and fall of the British empire, edited by Anil Seal (Cambridge: Cambridge University Press, 1982), in which he argues the terms of collaboration began to shift during the interwar period and renewed attempts at imperial control and development of the empire after 1945 served to provoke nationalist resistance and thereby raise the cost of collaboration yet further.

49 James S. Coleman, 'Nationalism in tropical Africa', American Political Science Review, 48:2 (1954), 404-26, 425. Early political science writing on nationalism tended to emphasize exogenous influences on the development of nationalism. A growth in interest in the endogenous dimensions was driven by historians, John Lonsdale perhaps chief among them, developing more nuanced social and political histories. For the first trend, see the Coleman article quoted above, as well as Thomas Hodgkin, Nationalism in colonial Africa (London: Frederick Muller, 1956); David E. Apter, Ghana in transition (Princeton, NJ: Princeton University Press, 1963); and Robert I. Rotberg, 'African nationalism: concept or confusion?' Journal of Modern African Studies, 4:1 (1966), 33-46. For a summary of early developments, see John Lonsdale, 'The emergence of African nations: a historiographical analysis', African Affairs, 67:266 (1968), 11-28; and, for a shift in focus, see John Lonsdale, 'Some origins of nationalism in East Africa', Journal of African History, 9:1 (1968), 119-46. Elie Kedourie (ed.), Nationalism in Asia and Africa (London: Routledge, 1974), is a later contribution of diverse essays. 
50 A leading proponent of the European and ideational roots of nationalism was Elie Kedourie in his Nationalism (London: Hutchinson, 1960), in which he states on page 1 that ' $[\mathrm{n}]$ ationalism is a doctrine invented in Europe at the beginning of the nineteenth century... Not the least triumph of this doctrine is that such propositions have become accepted and are thought to be self-evident... These ideas have become firmly naturalized in the political rhetoric of the West which has been taken over for the use of the whole world.' For an emphasis on the socio-economic dimension, but definitively the thorough-going European and modern nature of nationalism, see Ernest Gellner, Nations and nationalism (Oxford: Blackwell, 1983). The modernist perspective that held sway tended to tie in with the broader parameters of modernization theory and assume, from an almost entirely theoretical perspective, that African nations would develop greater degrees of unity and cohesion as they developed economically and socially. For an early proponent, see Karl W. Deutsch, Nationalism and social communication: an enquiry into the foundations of nationality (Cambridge, MA: MIT Press, 1953). In an entirely different critical postcolonial context, but strongly articulating the idea that nationalism originated in Europe and was thus essentially a foreign import, see Partha Chatterjee, Nationalist thought and the colonial world: a derivative discourse? (London: Zed Books, 1986).

51 For studies of pan-Africanism and anti-colonial networks in Europe and beyond, see Leslie James, George Padmore and decolonization from below: pan-Africanism, the cold war, and the end of empire (Basingstoke: Palgrave Macmillan, 2015); and Marc Matera, Black London: the imperial metropolis and decolonization in the twentieth century (Berkeley, CA: University of California Press, 2015), chs. 1-3; for a Parisian angle, see Michael Goebel, Anti-imperial metropolis: interwar Paris and the seeds of Third World nationalism (Cambridge: Cambridge University Press, 2015).

52 On the anti-colonial impetus of the First World War and ideas of self-determination, see Erez Manela, The Wilsonian moment: self-determination and the international origins of anticolonial nationalism (Oxford: Oxford University Press, 2007). For an alternative take on anti-colonial global networks, but nonetheless one that is predominantly elite in focus, see Michael Adas, 'Contested hegemony: the Great War and the Afro-Asian assault on the civilizing mission ideology', Journal of World History, 15:1 (2004), 31-63.

53 Paul Nugent, Africa since independence (Basingstoke: Palgrave Macmillan, 2012), 264-5. The spirit of 'second liberation' can be traced back to Frantz Fanon's Peau noire, masques blancs (Paris: Seuil, 1952) and Aimé Césaire's play Une saison au Congo (Paris: Seuil, 1966).

54 Originally Frantz Fanon, Les damnés de la terre (Paris: Éditions Maspero, 1961), this reference is to his The wretched of the Earth (New York, NY: Grove Press, 1963), 59.

55 Ibid., 147. Fanon became the standard-bearer for a particular type of emancipatory violence, endorsed by radical Europeans such as Jean-Paul Sartre, across the African continent from the mid- to late 1960s.

56 See Norrie MacQueen, The decolonization of Portuguese Africa: metropolitan revolution and the dissolution of empire (London: Longman, 1997).

57 On Portuguese resistance to decolonization and anti-colonial peasant mobilization, see Patrick Chabal, 'Emergencies and nationalist wars in Portuguese Africa', in Robert F. Holland (ed.), Emergencies and disorder in the European empires after 1945 (London: Frank Cass, 1994), 234-49; and Miguel Bandeira Jerónimo and António Costa Pinto, 'A modernizing empire? Politics, culture and economy in Portuguese late colonialism', in Miguel Bandeira Jerónimo and António Costa Pinto (eds.), The ends of European colonial empires: cases and comparisons (Basingstoke: Palgrave Macmillan, 2015), 51-80.

58 Perhaps the classic study here is Terence Ranger, Peasant consciousness and guerrilla war in Zimbabwe (London: James Currey, 1985). See also David Lan, Guns and rain: guerrillas and spirit mediums in Zimbabwe (London: James Currey, 1985); and Bhebe Ngwabi and Terence Ranger (eds.), Society in Zimbabwe's liberation war (Oxford: James Currey, 1996). For a critique, see Norma J. Kriger, Zimbabwe's guerrilla war: peasant voices (Cambridge: Cambridge University Press, 1992).

59 See, for example, Elizabeth Schmidt, 'Top down or bottom up? Nationalist mobilization reconsidered, with special reference to Guinea (French West Africa)', American Historical Review, 110:4 (2005), 975-1014; Elizabeth Schmidt, Cold War and decolonization in Guinea, 1946-1958 (Athens, OH: Ohio University Press, 2007); Daniel Branch, Defeating Mau Mau, creating Kenya: counterinsurgency, civil war, and decolonization (Cambridge: Cambridge University Press, 2009); and Emma Hunter, Political thought and the public sphere in 
Tanzania:freedom, democracy and citizenshipin the era ofdecolonization (Cambridge: Cambridge University Press, 2015). For a contribution cutting across history and political science, see Amanda Lea Robinson, 'National versus ethnic identification in Africa: modernization, colonial legacy, and the origins of territorial nationalism', World Politics, 66:4 (2014), 709-46.

60 Anderson, Histories of the hanged; see also Elkins, Britain's gulag; and Grob-Fitzgibbon, Imperial endgame.

61 Branch. Defeating Mau Mau, creating Kenya. See also Joanna Lewis, Empire state-building: war and welfare in Kenya 1925-52 (Oxford: James Currey, 2001).

62 Frederick Cooper, 'The dialectics of decolonization: nationalism and labor movements in post-war Africa', CCST Working Paper no. 84 (Ann Arbor, MI: University of Michigan, 1992); Frederick Cooper, 'Alternatives to nationalism in French Africa, 1945-60', in Jost Dülffer and Marc Frey (eds.), Elites and decolonization in the twentieth century (Basingstoke: Palgrave Macmillan, 2011), 110-37, 111. For other iterations of this position, see Frederick Cooper, 'Possibility and constraint: African independence in historical perspective', Journal of African History, 49:2 (2008), 167-96; and, most comprehensively, Frederick Cooper, Citizenship between empire and nation: remaking France and French Africa, 1945-1960 (Princeton, NJ: Princeton University Press, 2014). See also Wilder, Freedom time.

63 On the links between pan-Africanism and the federalists of West Africa, see Schmidt, Cold war and decolonization in Guinea; and Elizabeth Schmidt, 'Pan-Africanism, people's power and decolonization in Ghana and Guinea: the uneven legacy of Kwame Nkrumah and Sékou Touré', in Toyin Falola and Emily Brownell (eds.), Africa, empire and globalization: essays in honor of A. G. Hopkins (Durham, NC: Duke University Press, 2011), 525-40.

64 Albeit within an Algerian rather than a sub-Saharan African context, this argument was originally made in a very persuasive form by Shepard in his Invention of decolonization.

65 Cooper posits at least three options for African nationalist leaders: '[D]id the "nation" lie in the numerous and diverse units of African society, and the territorial boundaries imposed by colonization less than a century previously, in larger units of cooperation and potential solidarity, such as French West Africa, in a pan-African vision of solidarity, or in a French nationality and citizenship, purged of invidious inequality?' Cooper, 'Alternatives to nationalism', 110.

66 Jost Dülffer and Marc Frey, 'Introduction', in Dülffer and Frey, Elites and decolonization, $1-10,3$.

67 In fact, with Europeans pushing for federal alternatives to the nation state in Europe itself, the Dutch also experimenting with federal options during decolonization and the British pushing federations in the West Indies, South Arabia and Malaya, it has been suggested that federal thinking after 1945 constituted a broad moment of doubt about the viability and desirability of nation states in the post-war period. See Collins, 'Decolonization and the "federal moment".

68 Samuel Moyn, 'Fantasies of federalism', Dissent, 62:1 (2015), 145-51.

69 Hannah Alice Whittaker, 'The socio-economic dynamics of the Shifta conflict in Kenya, 19638', Journal of African History, 53:3 (2012), 391-408.

70 Hunter, Political thought and the public sphere.

71 See, in particular, Joseph-Roger de Benoist, La balkanisation de l'Afrique Occidentale française (Dakar: Nouvelles éditions africaines, 1979); and Kwame Nkrumah, Neo-colonialism: the last stage of imperialism (London: Thomas Nelson \& Sons, 1965).

72 Hent Kalmo and Quentin Skinner, Sovereignty in fragments: the past, present and future of a contested concept (Cambridge: Cambridge University Press, 2010), 14.

73 Irwin makes a strong case for the importance of how decolonization fulfilled what he calls 'the logic of mid-century liberal internationalism': Ryan M. Irwin, 'Decolonization and the Cold War', in Artemy M. Kalinovsky and Craig Daigle (eds.), The Routledge handbook of the Cold War (London: Routledge, 2014), 91-104. See also the essays on Africa in Leslie James and Elisabeth Leake (eds.), Decolonization and the Cold War: negotiating independence (London: Bloomsbury, 2015); and Jeffrey James Byrne, 'The Cold War in Africa', in Kalinovsky and Daigle, The Routledge handbook of the Cold War, 149-62. For important earlier contributions, see John Kent, The internationalization of colonialism: Britain, France and black Africa, 1939-1956 (Oxford: Oxford University Press, 1992); and Kent Fedorowich and Martin Thomas (eds.), International diplomacy and colonial retreat (London: Frank Cass, 2001).

74 Michael Collins, 'Decolonization', in John MacKenzie (ed.), The encyclopedia of empire (Chichester: Wiley, 2016), http://onlinelibrary.wiley.com/doi/10.1002/9781118455074. wbeoe360/full (accessed 17 December 2015).

75 Manela, The Wilsonian moment. 
76 Ryan M. Irwin, 'Imagining nation, state, and order in the mid-twentieth century', Kronos, 37:1 (2011), 12-22. See also Christopher J. Lee (ed.), Making a world after empire: the Bandung moment and its political afterlives (Athens, OH: Ohio University Press, 2010).

77 Goebel, Anti-imperial metropolis, 251, emphasis original.

78 Ibid. Goebel's position finds support in the work of Cemil Aydin, among others. See, for example, Cemil Aydin, 'Pan-nationalism of pan-Islamic, pan-Asian, and pan-African thought', in John Breuilly (ed.), The history of nationalism (Oxford: Oxford University Press, 2013), 672-93.

79 See David K. Fieldhouse, The West and the Third World: trade, colonialism, dependence and development (Oxford: Blackwell, 1999); see also Sarah Stockwell, The business of decolonization: British business strategies in the Gold Coast (Oxford: Oxford University Press, 2000).

80 For a more specific case study, see Colin Leys, Underdevelopment in Kenya: the political economy of neo-colonialism (London: Heinemann, 1975). For other versions of dependency, see Wolfgang J. Mommsen and Jürgen Osterhammel (eds.), Imperialism and after: continuities and discontinuities (London: Allen \& Unwin, 1986). For a more critical examination, see Paul Hirst and Grahame Thompson, Globalization in question (Cambridge: Polity, 1996).

81 William Roger Louis and Ronald E. Robinson, 'The imperialism of decolonization', Journal of Imperial and Commonwealth History, $22: 3$ (1994), 462-511.

82 Fieldhouse, The West and the Third World, 295.

83 On economics and French decolonization, see Edward Peter Fitzgerald, 'Did France's colonial empire make economic sense? A perspective from the postwar decade, 1946-1956', Journal of Economic History, 48:2 (1988), 373-85; and Elise Huillery, 'History matters: the long-term impact of colonial public investments in French West Africa', American Economic Journal: Applied Economics, 1:2 (2009), 176-219. On the British side, see, for example, Stockwell, The business of decolonization; and Andrew Cohen, The politics and economics of decolonization in Africa: the failed experiment of the Central African Federation (London: I. B. Tauris, 2016). On British metropolitan dimensions, see, among others, David K. Fieldhouse, 'The metropolitan economics of empire', in Judith M. Brown and William Roger Louis (eds.), The Oxford history of the British empire, vol. IV, The twentieth century (Oxford: Oxford University Press, 1999), 88-113; Peter J. Cain and Tony Hopkins, British imperialism 1688-2000 (London: Longman, 2002), 619-44; Jim Tomlinson, 'The decline of empire and the economic "decline" of Britain', Twentieth Century British History, 14:3 (2003), 201-21; and Catherine Schenk, The decline of sterling: managing the retreat of an international currency 1945-1992 (Cambridge: Cambridge University Press, 2010).

84 Ichiro Maekawa, 'Neo-colonialism reconsidered: a case study of East Africa in the 1960s and 1970s', Journal of Imperial and Commonwealth History, 43:2 (2015), 317-41. Maekawa claims, with some plausibility, that 'the concept of neocolonialism has not been sufficiently verified by historical evidence' (319).

85 See Alamin M. Mazrui, 'Decaying parts of Africa need benign colonization', in Alamin M. Mazrui and Willy Mutunga (eds.), Governance and leadership: debating the African condition (Trenton, NJ: Africa World Press, 2003), 339-41. The most startling ad hominem attack on Mazrui was Archie Mafeje, "'Benign” colonialism and malignant minds in the service of imperialism', in Mazrui and Mutunga, Governance and leadership, 342-9, where he asserts that 'Ali Mazrui's discourse on "benign colonialism" is intellectually bankrupt, analytically superficial, sensational, and downright dishonest' (346). This prompted a stinging reply from Mazrui: Alamin M. Mazrui, 'Self-colonization and the search for pax-Africana: a rejoinder', in Mazrui and Mutunga, Governance and leadership, 350-5.

86 Robert H. Jackson, Quasi-states: sovereignty, international relations, and the Third World (Cambridge: Cambridge University Press, 1990), 98-108.

87 Ibid., 21. For later 'post-9/11' iterations, see Christopher Clapham, 'The global-local politics of state decay', in Robert I. Rotberg (ed.), When states fail: causes and consequences (Princeton, NJ: Princeton University Press, 2004), 77-93, who uses the term 'legal fiction' to account for an African sovereignty that is 'little more than a pretence, maintained by the international system because it lacks any intellectual or legal framework other than statehood' (82). Again, the explanation for this begins with colonialism and decolonization.

88 The classic contribution here comes from Crawford Young in his The African colonial state in comparative perspective (New Haven, CT: Yale University Press, 1994).

89 Eghosa A. Osaghae, 'A state of our own: second independence, federalism and the decolonization of the state in Africa', Emeka Anyaoku Visiting Chair in Commonwealth Studies inaugural lecture, Senate House, University of London, 9 April 2014. 
90 Peter P. Ekeh, 'The concept of second liberation and the prospects of democracy in Africa: a Nigerian context', in Paul A. Beckett and Crawford Young (eds.), Dilemmas of democratization in Nigeria (Rochester, NY: University of Rochester Press, 1997), 83-110, 96, 101.

91 As Dülffer and Frey suggest in their introduction to their edited volume on Elites and decolonization in the twentieth century, the 'key to understanding the transition from the colonial to the post-colonial is agency'. In other words, 'individuals and social groups shaped decolonization', through actors struggling and fighting for independence, while 'others tried to retard or suppress it, while still others simply try to accommodate the fundamental changes in the political, economic, social, cultural rounds as best as possible': Dülffer and Frey, 'Introduction', 2.

92 Mahmood Mamdani, Citizen and subject: contemporary Africa and the legacy of late colonialism (Princeton, NJ: Princeton University Press, 1996).

93 Frederick Cooper, Decolonization and African society: the labor question in French and British Africa (Cambridge: Cambridge University Press, 1996).

94 Frederick Cooper, Africa since 1940: the past of the present (Cambridge: Cambridge University Press, 2002), 5.

95 Ibid., 5-6.

96 Low and Lonsdale, 'Introduction: towards the new order', 12. On the nexus between metropolitan planning, colony-specific institutions and the international or 'global' sphere, the authors suggest that, 'although the scale of British economic planning was not global, the institutional sinews of development remained firmly embedded in each territory [and] the close interrelationship between economic and political development was now the topic of empire'.

97 For a detailed discussion of the evolving historiography on the late colonial state, see Darwin, 'What was the late colonial state?'.

98 Martin Shipway, Decolonization and its impact: a comparative approach to the end of the colonial empires (Malden, MA: Blackwell, 2008), xx. For more specific applications to French West Africa, see Martin Shipway, 'Thinking like an empire: Governor Henri Laurentie and postwar plans for the late colonial French "empire-state"', in Martin Thomas (ed.), The French colonial mind, vol. I, Mental maps of empire and colonial encounters (Lincoln, NE: Nebraska University Press, 2011), 219-50; and Martin Shipway, 'Gaston Defferre's Loi-Cadre and its application 1956/57: the last chance for a French African "empire-state" or blueprint for decolonisation?', in Tony Chafer and Alexander Keese (eds.), Francophone Africa at fifty (Manchester: Manchester University Press, 2013), 15-29. See also Andrew W. M. Smith, 'Of colonial futures and an administrative Alamo: investment, reform and the loi cadre (1956) in French West Africa', French History, 28:1 (2014), 92-113.

99 For a sophisticated account of the export of metropolitan welfare and social engineering projects to a colonial setting, and of the complex African response, see Lewis, Empire state-building.

100 For a fascinating take on the ongoing interest in colonial careering in Africa, see Chris Jeppesen, "Sanders of the river, still the best job for a British boy": recruitment to the Colonial Administrative Service at the end of empire', Historical Journal, 59:2 (2016), 469-508. For broader discussions of the colony-metropole link at the end of empire, see Elizabeth Buettner, Europe after empire: decolonization, society, and culture (Cambridge: Cambridge University Press, 2016); Stuart Ward (ed.), British culture and the end of empire (Manchester: Manchester University Press, 2001); Bill Schwarz, Memories of empire, vol. I, The white man's world (Oxford: Oxford University Press, 2011); Jordanna Bailkin, The afterlife of empire (Berkeley, CA: University of California Press 2012); and Andrew Thompson (ed.), Britain's experience of empire in the twentieth century (Oxford: Oxford University Press, 2011). On the French side, Herman Lebovics, Bringing the empire back home: France in the global age (Durham, NC: Duke University Press, 2004) is a useful introduction to the range of themes in play.

101 A fascinating collection of essays looking at the French angle is to be found in Martin Thomas (ed.), The French colonial mind, vol. II, Violence, military encounters, and colonialism (Lincoln, NE: Nebraska University Press, 2011).

102 This is testament to the ongoing utility of Ronald Robinson's concept, developed through his work with Jack Gallagher but elucidated most fully in his essay 'Non-European foundations of European imperialism: sketch for a theory of collaboration', in Roger Owen and Bob Sutcliffe (eds.), Studies in the theory of imperialism (London: Longmans, 1972), 117-42. See, for example, Benjamin N. Lawrance, Emily Lynn Osborn and Richard L. Roberts, 
'Introduction: African intermediaries and the "bargain" of collaboration', in Benjamin N. Lawrance, Emily Lynn Osborn and Richard L. Roberts (eds.), Intermediaries, interpreters, and clerks: African employees in the making of colonial Africa (Madison, WI: University of Wisconsin Press, 2006), 3-36.

103 For an overview, see Andrew R. Dilley, 'The economics of empire', in Sarah Stockwell (ed.), The British empire: themes and perspectives (Oxford: Blackwell, 2008), 101-30. On taxation and the African colonial state, see Leigh A. Gardner, Taxing colonial Africa: the political economy of British imperialism (Oxford: Oxford University Press, 2012).

104 Ann Laura Stoler, Capitalism and confrontation in Sumatra's plantation belt, 1870-1979 (Ann Arbor, MI: University of Michigan Press, 1995). This reminds us too of Fred Cooper's Decolonization and African society, in which he suggests that much labour and trade union activity was wrongly conflated with nationalist agitation. The blurring of the lines by colonial authorities between labour disputes, nationalist activities and criminality added to this tendency.

105 Martin Thomas, Violence and colonial order: police, workers and protest in the European colonial empires, 1918-1940 (Cambridge: Cambridge University Press, 2012).

106 On surveillance and intelligence gathering in the French empire, see Martin Thomas, 'Colonial states as intelligence states: security policing and the limits of colonial rule in France's Muslim territories, 1921-40', Journal of Strategic Studies, 28:6 (2005), 1033-60; A broader piece by the same author covering both British and French sub-Saharan Africa is Martin Thomas, 'Intelligence providers and the fabric of the late colonial state', in Dülffer and Frey, Elites and decolonization, 11-35.

107 Thomas, Violence and colonial order, 19.

108 David Scott has neatly summarized the nationalist and postcolonial moments as representing different historical 'problem spaces'. Crucially, for postcolonialists, the conceptual paradigms and political projects defined in relation to Marxism and nationalism seemed 'no longer adequate to the tasks of the present'. The " "problem-space" of the anti-colonial project had...been defined by the demands of political decolonization, the demand for the overthrow of colonial power. Its goal was the achievement of political sovereignty.' What was not theorized was 'the whole question of the decolonization of representation itself'. Hence the postcolonial perspective recognized the illusory nature of decolonization as 'flag independence' and the derivative nature of nationalism. What was now required was 'the decolonization of representation, the decolonization of the West's theory of the nonWest'. This of course constituted both a critique of actually existing decolonization as at best partial and a new conceptual and hence historiographical opening, once again bringing the European imperial states and the newly independent states - now the 'colonizer' and the 'colonized', in postcolonial terminology - into contact once again. See David Scott, Refashioning futures: criticism after postcoloniality (Princeton, NJ: Princeton University Press, 1999), 10-13. Richard Drayton uses the term 'secondary decolonization' in a similar way: see Richard Drayton, 'Secondary decolonization: the black power moment in Barbados, c. 1970', in Kate Quinn (ed.), Black power in the Caribbean (Gainsville, FL: University Press of Florida, 2014), 117-35. Although the epistemological dimensions of postcolonialism were formulated in new ways, the dangers of a derivative nationalism as the pathway out of colonialism had been debated vigorously and extensively at a much earlier decolonizing moment, between the Indian poet-philosopher Rabindranath Tagore and the (reluctant) nationalist Mohandas K. Gandhi. For a fuller discussion, see Michael Collins, Empire, nationalism and the postcolonial world: Rabindranath Tagore's writings on politics, history and society (London: Routledge, 2012).

109 For an early exploration of the potential significance of Foucault for the study of imperial history and decolonization, see David Scott, 'Colonial governmentality', Social Text, 43:2 (1995), 191-220.

110 James Ferguson, The anti-politics machine (Cambridge: Cambridge University Press, 1990). See also James C. Scott, Seeing like a state: how certain schemes to improve the human condition have failed (New Haven, CT: Yale University Press, 1998).

111 Stephen Howe, 'David Fieldhouse and “imperialism": some historiographical revisions', Journal of Imperial and Commonwealth History, 26:2 (1998), 213-32, 224.

112 Achille Mbembe, On the postcolony (Berkeley, CA: University of California Press, 2001).

113 Andrew Zimmerman, 'Africa in imperial and transnational history: multi-sited historiography and the necessity of theory', Journal of African History, 54:3 (2013), 331-40. 
114 Christophe Bonneuil, 'Development as experiment: science and state-building in late colonial and postcolonial Africa, 1930-1970', Osiris, 15 (2000), 258-81, 260. Bonneuil's work builds upon earlier studies of science and empire; for examples, see Michael Adas, 'A field matures: technology, science, and western colonialism', Technology and Culture, 38:2 (1997), 478-87. The 1997 edited volume by Fred Cooper and Randall Packard International development and the social sciences - also constituted an important moment in the inauguration of a new turn towards the history of knowledge production and its application in late colonial and decolonizing contexts. See Frederick Cooper and Randall Packard (eds.), International development and the social sciences: essays on the history and politics of knowledge (Berkeley, CA: University of California Press, 1997), especially the essays on Africa by Cooper and James Ferguson, and particularly the contribution on Senegal by Mamadou Diouf.

115 Some examples from a wide field include Sabine Clarke, 'A technocratic imperial state? The Colonial Office and scientific research, 1940-1960', Twentieth Century British History, 18:4 (2007), 453-80; Joseph Morgan Hodge, Triumph of the expert: agrarian doctrines of development and the legacies of British colonialism (Athens, $\mathrm{OH}$ : Ohio University Press, 2007); Kate Skinner, 'Who knew the minds of the people? Specialist knowledge and developmentalist authoritarianism in postcolonial Ghana', Journal of Imperial and Commonwealth History, 39:2 (2011), 297-323; Brett Bennett and Joseph Morgan Hodge (eds.), Science and empire: knowledge and networks of science in the British empire 1800 1970 (Basingstoke: Palgrave Macmillan, 2011); Matthew M. Heaton, Black skin, white coats: Nigerian psychiatrists, decolonization, and the globalization of psychiatry (Athens, OH: Ohio University Press, 2013); Karl Ittmann, A problem of great importance: population, race, and power in the British empire, 1918-1973 (Berkeley, CA: University of California Press, 2013); Erik Linstrum, Ruling minds: psychology in the British empire (Cambridge, MA: Harvard University Press, 2016); and James McDougall, 'Rule of experts? Governing modernisation in late colonial French Africa', in Ed Naylor (ed.), France's modernising mission: welfare, citizenship, and the ends of empire (Basingstoke: Palgrave Macmillan, 2017).

116 For an overview of this new field and its concerns, present and potential, see Rob Skinner and Alan Lester, 'Humanitarianism and empire: new research agendas', Journal of Imperial and Commonwealth History, 40:5 (2012), 729-47. In the context of decolonization and violence, see Fabian Klose, 'The colonial testing ground: the International Committee of the Red Cross and the violent end of empire', Humanity: An International Journal of Human Rights, Humanitarianism, and Development, 2:1 (2011), 107-26. The history of humanitarianism has the potential to open up new links between empire and 'home' during decolonization. See Matthew Hilton, 'Ken Loach and the Save the Children film: humanitarianism, imperialism, and the changing role of charity in postwar Britain', Journal of Modern History, 87:2 (2015), 357-94.

117 Richard Price, 'One big thing: Britain, its empire, and their imperial culture ', Journal of British Studies, 45:3 (2006), 602-27, 603.

118 The 'network' may be an overused category of historical analysis, but it does provide new ways to think about the history and longevity of empire in wider, 'global' settings. For a cautionary tale, see David A. Bell, 'This is what happens when historians overuse the idea of the network', New Republic, 26 October 2014, https://newrepublic.com/article/114709/world-connectingreviewed-historians-overuse-network-metaphor (accessed 22 October 2015).

119 If looking beyond national frameworks suggests the importance of international, transnational, supranational and subnational loyalties in both destabilizing and reinforcing the nation state as an organizing category of twentieth-century world history, there are further options and alternative historiographies for thinking beyond the nation state. The history of African cities may well be a revealing area of future study for understanding both Africa's past and future: see Bill Freund, The African city: a history (Cambridge: Cambridge University Press, 2007).

\section{Chapter 2}

1 See, for example, Keith Jeffrey, 'The Second World War', in Judith M. Brown and William Roger Louis (eds.), The Oxford history of the British empire, vol. IV, The twentieth century 
(Oxford: Oxford University Press, 1999), 306-28, 327: 'Paradoxically, the ultimate cost of defending the British empire during the Second World War was the empire itself'; and Nicholas J. White, 'Reconstructing Europe through rejuvenating empire: the British, French, and Dutch experiences compared', Past and Present, supplement 6 (2011), 211-36, 236.

2 D. A. Low and John Lonsdale, 'Introduction: towards the new order, 1945-1963', in D. A. Low and Alison Smith (eds.), History of East Africa, vol. III (Oxford: Clarendon Press, 1976), 1-63.

3 These reflections come from an ongoing project that focuses on the history of the British Labour Party's approach to overseas aid and development, from the interwar period to the creation of the Department for International Development (DFID) in 1997. Charlotte Lydia Riley, An ethical foreign policy? The British Labour Party and overseas development from the 1920 s to the 1970s (forthcoming).

4 Such as James Midgley and David Piachaud's Colonialism and welfare: social policy and the British imperial legacy (Cheltenham: Edward Elgar, 2011); Mark Duffield and Vernon Hewitt's Empire, development and colonialism: the past in the present (Woodbridge: James Currey, 2009); and Helen Gilbert and Chris Tiffin's Burden or benefit? Imperial benevolence and its legacies (Bloomington, IN: Indiana University Press, 2008).

5 Michael Barnett, Empire of humanitarianism: a history of humanitarianism (Ithaca, NY: Cornell University Press, 2011).

6 See especially Michael Jennings, Surrogates of the state: NGOs, development, and Ujamaa in Tanzania (West Hartford, CT: Kumarian Press, 2008); and Joseph Morgan Hodge, Triumph of the expert: agrarian doctrines of development and the legacies of British colonialism (Athens, OH: Ohio University Press, 2007).

7 Hodge, Triumph of the expert, 263.

8 Philippa Levine, The British empire: sunrise to sunset (London: Longman, 2007), 107.

9 Ann Laura Stoler and Frederick Cooper, 'Between metropole and colony: rethinking a research agenda', in Ann Laura Stoler and Frederick Cooper (eds.), Tensions of empire: colonial cultures in a bourgeois world (Berkeley, CA: University of California Press, 1997), 1-56.

10 Overseas Development Institute, Colonial development: a factual survey of the origins and history of British aid to developing countries (London: ODI Publications, 1964), 12; for more information on interwar development policies, see Michael Havinden and David Meredith, Colonialism and development: Britain and its tropical colonies, 1950-1960 (Abingdon: Routledge, 1996), 140-206.

11 ODI, Colonial development, 12.

12 W. Rick Garside, British unemployment 1919-1939: a study in public policy (Cambridge: Cambridge University Press, 2002), 198-9.

13 Malcolm MacDonald, cited in Ronald Hyam, Britain's declining empire: the road to decolonisation 1918-1968 (Cambridge: Cambridge University Press, 2006), 86.

14 Civil estimates class II, 12 (1949-50) Main note (April 1949), 'Development and welfare' (Colonies \&c.), 2, T 165/109, National Archives.

15 Ibid.

16 Ibid., 2-3.

17 Ibid., 3.

18 Ibid.

19 Ibid., 'Table A: Estimates and expenditure from 1940-41', 6.

20 Ibid., 3.

21 Kathryn Tidrick, Empire and the English character: the illusion of authority (London: Tauris Parke, 1990), 256.

22 Rita Hinden, 'Economic plans and problems in the British colonies', World Affairs, 112:3 (1949), 77-9, 77.

23 Tidrick, Empire and the English character, 256.

24 See, for example, Stephen Howe, Anti-colonialism in British politics: the left and the end of empire (Oxford: Clarendon Press, 1993), in which Howe focuses on areas of Labour ideology and practice that fit into a broader narrative of left-wing anti-imperial thinking.

25 Bernard Porter, Critics of empire: British radicals and the imperial challenge, 2nd edn (London: I. B. Tauris, 2008), 306.

26 Patricia Pugh, Educate, agitate, organise: 100 years of Fabian socialism (London: Methuen, 1984), 189.

27 Josephine Fishel Milburn, 'The Fabian Society and the British Labour Party', Western Political Quarterly, 11:2 (1958), 319-40, 336-7; Kenneth O. Morgan, 'Imperialism at bay: British 
Labour and decolonization', Journal of Imperial and Commonwealth History, 27:2 (1999), 233-54, 236.

28 Pugh, Educate, agitate, organise, 198.

29 Memorandum no. 205 by Norman Leys on 'Labour's colonial policy', Labour Party advisory committee on imperial questions, with an appendix - February 1939, Box 16 file 2 ff. 23-30, Bodl. RH, Creech Jones MSS, MS Brit. Emp. s. 332.

30 Rita Hinden, 'Socialism and the colonial world', in Arthur Creech Jones (ed.), New Fabian colonial essays (London: Hogarth Press, 1959), 9-18, 9.

31 Arthur Creech Jones, 'A visit to West Africa', The Left News, August 1944, Box 9, File 3, Bodl. RH, Creech Jones MSS, MS Brit. Emp. s. 332.

32 Ibid.

33 Charles R. Buxton, 'Note on Colonial Office vote', 7 June 1939, Box 16, File 2, ff.61-3, Bodl. $\mathrm{RH}$, Creech Jones MSS, MS Brit. Emp. s. 332.

34 Jones, 'A visit to West Africa'.

35 Buxton, 'Note on Colonial Office vote'.

36 Paul Kelemen, 'Modernising colonialism: the British Labour movement and Africa', Journal of Imperial and Commonwealth History, 34:2, (2006), 223-44, 225.

37 Anon., 'What is Labour doing?' Venture: A Socialist Commentary on Colonial Affairs: Journal of the Fabian Colonial Bureau, 2:8 (1950), 2.

38 Hinden, 'Socialism and the colonial world', 14.

39 Ibid.

40 See, for example, Robert Pearce, The turning point in Africa: British colonial policy, 1938-48 (London: Routledge, 1982), 90-127, 144-5; David Goldsworthy, Colonial issues in British politics 1945-61: from 'colonial development' to 'wind of change' (Oxford: Clarendon Press, 1971), 113-64.

41 Michael Cowen and Robert Shenton, 'The origin and course of Fabian colonialism in Africa', Journal of Historical Sociology, 4:2 (1991), 143-74, 144.

42 Memorandum by Arthur Creech Jones of colonial policy of Labour administration, c. 1947, Box 4, File 4, f.2-5, Bodl. RH, Creech Jones MSS, MS Brit. Emp. s. 332.

43 Arthur Creech Jones, 'Circular despatch to the officer administering the government of (all colonies, protectorates and mandates)', 10 July 1947, CO 537/2002.

44 Minute, S. C. to C. G. Eastwood, 21 March 1947, CO 537/2002.

45 By 1951 the OFC had collapsed under the strain of the failed Groundnuts Scheme, but the CDC remained a force for state-sponsored development after decolonization, working mainly - but not exclusively - in former colonial nations. It was renamed the Commonwealth Development Corporation in 1963, and was eventually rebranded as the CDC Group PLC. There is a (heavily edited) history of the CDC on its website, www.cdcgroup.com/ company-history.

46 For a more in-depth discussion of these interdepartmental tensions and how they shaped colonial rule, see Charlotte Lydia Riley, “Tropical allsorts": the transnational flavour of British development policies in Africa', Journal of World History, 26:4 (2015), 839-64.

47 Sydney Caine, 'British experiences in overseas development', Annals of the American Academy of Political and Social Science, 270 (1950), 118-25, 123.

48 Frank Heinlein, British government policy and decolonisation, 1945-1963: scrutinising the official mind (London: Frank Cass, 2002), 28, emphasis original.

49 This continuation was also a transnational phenomenon. Joseph Morgan Hodge has demonstrated how British colonial expertise at the end of empire was not dissolved but was instead co-opted into new organizations, such as the World Bank, the United Nations Relief and Rehabilitation Administration and the Food and Agriculture Organization. Joseph Morgan Hodge, 'British colonial expertise, postcolonial careering and the early history of international development', Journal of Modern European History, 8:1 (2010), 24-46.

50 Barbara Castle, 'Barbara Castle says: this way to peace!', 1955, Election addresses, Special collections, University of Bristol.

51 Jane Morton, 'Labour Party overseas department: economic aid to undeveloped countries (draft)', Nov/Dec 1963, MSS Castle 258, Barbara Castle Papers, Bodleian, Oxford.

52 Ibid.

53 Barbara Castle, 'International aid development association bill', HC Deb, 3 February 1964, vol. 688, cc. 846.

54 Ibid. 
55 ODI, Overseas development: the work of the new ministry, Cmnd. 2736 (London: Stationery Office, 1965).

56 Andrew Cohen, 'Development in Africa', African Affairs, 67:266 (1968), 44-54, 48; Simon James, British government: a reader in policy making (London: Routledge, 1997), 115.

57 Tom Soper, Aid management overseas (London: ODI Publications, 1967), 5.

58 Anon., 'No votes in aid?', Economic and Political Weekly, 5:6 (1970), 288-90, 288.

59 Ibid., 289.

60 AndrewMitchell,'Newlogo:flyingtheflagforUKaid',DepartmentforInternationalDevelopment, 25 June 2012, www.gov.uk/government/news/new-logo-flying-the-flag-for-uk-aid.

\section{Chapter 3}

1 See, for example, Ray Takeyh, The origins of the Eisenhower doctrine: the US, Britain and Nasser's Egypt, 1953-57 (New York, NY: Palgrave, 2000); Benjamin Stora, Histoire de la guerre d'Algérie, 1954-1962 (Paris: La Découverte, 2004); and Michael Burgess, Federalism and the European Union: the building of Europe, 1950-2000 (London: Routledge, 2000).

2 For an account of the ideological evolution of the FLN and how it envisaged its role in international affairs, see Jeffrey Byrne, Mecca of revolution: Algeria, decolonization, and the Third World order (Oxford: Oxford University Press, 2016).

3 See Oscar Sanchez-Sibony, Red globalization: the political economy of the Soviet Cold War from Stalin to Khrushchev (Cambridge: Cambridge University Press, 2014).

4 Leslie E. Grayson, National oil companies (Chichester: Wiley, 1981).

5 Petroleum Press Service, April 1956.

6 Historical archives of the European Union, EEC, Energy Commission, Report OEEC on the Sahara, April 1958.

7 Ibid.

8 The North Sea fields were not discovered until the 1970s.

9 Yves Delavesne, 'L'Industrie du pétrole', Annales des mines, June 1960.

10 Henry Cattan, The law of oil concessions in the Middle East and North Africa (New York, NY: Parker School of Foreign and Comparative Law, 1981).

11 Delavesne, 'L'Industrie du pétrole'.

12 See Ethan B. Kapstein, The insecure alliance: energy crises and Western politics since 1944 (Oxford: Oxford University Press, 1990); Daniel Yergin, The prize: the epic quest for oil, money and power (New York, NY: Free Press, 2008); Leonardo Maugeri, L'era del petrolio: mitologia, storia e future della più controversa risorsa del mondo (Milan: Feltrinelli, 2006); and Daniel Durand, La politique pétrolière internationale (Paris: Persée, 1970).

13 Durand, La politique pétrolière internationale.

14 See Petroleum Press Service, April 1956; and Historical archives of the European Union, EEC, Energy Commission, Report by the Energy Commission, October 1958.

15 Ibid. For an insight into how the Cold War framework shaped the interaction of Europe and 'Third-Worldism', see also Giuliano Garavini, After empires: European integration, decolonization, and the challenge from the global South (Oxford: Oxford University Press, 2012).

16 Edith Penrose, The large international firm in developing countries: the international petroleum industry (London: Allen \& Unwin, 1968), 19.

17 Paul Frankel, Mattei: Oil and power politics (London: Faber, 1968).

18 Ibid.

19 See Penrose, The large international firm in developing countries; and J. Ernest Hartshorn, Oil companies and governments: an account of the international oil industry and its political environment (New York, NY: Perseus, 1969).

20 Frankel, Mattei.

21 Geoffrey Chandler, 'Obituary: Paul Frankel', The Independent, 29 October 1992, www. independent.co.uk/news/people/obituary-paul-frankel-1560213.html (accessed 20 January 2014).

22 Frankel, Mattei, 102.

23 Frankel, Mattei. 
24 Durand, La politique pétrolière internationale.

25 ENI Archives, Corrispondenza sulle ricerche nel Sahara. For CFP, see Maugeri, L'era del petrolio; and Daniele Pozzi, Dai gatti selvaggi al cane a sei zampe (1926-1967) (Venice: Marsilio, 2009).

26 Roberto Cantoni, Oily deals: exploration, diplomacy and security in early Cold War France and Italy (unpublished PhD dissertation, University of Manchester, 2014).

27 Andrew W. M. Smith, 'Of colonial futures and an administrative Alamo: investment, reform and the loi cadre (1956) in French West Africa', French History 28:1 (2014), 92-113, 97.

28 Historical archives of the European Union, Uwe Kitzinger and Noël Salter Documentation, Investimenti paesi Europei nell'industria petrolifera al $1^{\circ}$ gennaio 1962; Historical archives of the European Union, Report by the energy commission.

29 Petroleum Press Service, October 1958.

30 Pierre Cornet, Sahara: terre de demain (Paris: Nouvelles éditions latines, 1956).

31 Cornet, Sahara: terre de demain.

32 Gabriel Vangrevelinghe, 'Les niveaux de vie en France, 1956 et 1965', Économie et statistique, $1: 1$ (1969), 7-21.

33 On Eurafrica, see Cornet, Sahara: terre de demain; Papa Dramé and Samir Saul, 'Le projet d'Eurafrique en France (1946-1960): quête de puissance ou atavisme colonial?', Guerres mondiales et conflits contemporains, 216 (2004), 95-114; Yaël Kouzmine, Le Sahara algérien: intégration national et développement régional (Paris: L'Harmattan, 2012); Peo Hansen and Stefan Jonsson, Eurafrica: the untold history of European integration and colonialism (London: Bloomsbury, 2014); Martin Shipway, Decolonization and its impact: a comparative approach to the end of the colonial empires (Malden, MA: Blackwell, 2008); and Tony Chafer, The end of empire in French West Africa: France's successful decolonization? (Oxford: Berg, 2002).

34 Kouzmine, Le Sahara algérien, 21.

35 Expression of Erik Labonne, in Dramé and Saul, 'Le projet d'Eurafrique en France' (translation by the author).

36 Cornet, Sahara: terre de demain, 240.

37 Ibid. (translation by the author).

38 Louis Blin, L'Algérie, du Sahara au Sahel: route transsaharienne, économie pétrolière et construction de l'état (Paris: L'Harmattan, 1990), 89; Jean Loyrette, Le code pétrolier saharien (Paris: Librairie générale de droit et de jurisprudence, 1961).

39 See ibid.; and Cornet, Sahara: terre de demain.

40 See Petroleum Press Service, June 1956; and Blin, L’Algérie, du Sahara au Sahel.

41 Cornet, Sahara: terre de demain.

42 Cantoni, Oily deals.

43 Pierre Fontaine, Bataille pour le pétrole française (Paris: Je Sers, 1956).

44 US National Archives and Records Administration [hereafter NARA], RG 59, Central Decimal File, 1955-59, French Africa, b. 4604, f. 851S.2553/4-1858, DS, memorandum of conversation between Jean de la Grandville, counsellor, French embassy, and Matthew Looram, WE, confidential: 'Algeria: reports re Aramco subsidizing the Algerian rebels', 18 April 1956. In Cantoni, Oily deals.

45 NARA, RG 59, Central Decimal File, 1955-59, French Africa, b. 3378, f. 751S.00/11-756, DS, telegram from US embassy in Paris to Secretary of State, confidential, 7 November 1956, signed Dillon; Archivio Storico del Ministero degli Affari Esteri, Ambasciata d'Italia a Parigi [Italian embassy in Paris], 1951-58 - b. 74 (Algeria '57), Pietro Quaroni to Italian Foreign Ministry, Italian embassies in London and Washington: 'Presunti aiuti americani alla ribellione algerina', 5 February 1957. In Cantoni, Oily deals.

46 NARA, RG 59, Central Decimal File, 1955-59, French Africa, b. 3378, f. 751S.00/11-1456, DS, memorandum of conversation between James T. Duce, vice president, Aramco, and Fraser Wilkins, director, NE, official use only: 'Fund for the Algerian rebels', 14 November 1956; Archives nationales [hereafter AN], b. 19900317/8, fd. 1, sub-fd. Afrique 1957/77, secret, Note SDECE, Position américaine vis-à-vis de la présence française en Afrique, 9 July 1957 (FOIA no. 111,382). In Cantoni, Oily deals.

47 Arthur Schlesinger, A thousand days: John F. Kennedy in the White House (Boston, MA: Houghton Mifflin, 1965), 510 et seq., quoted in Bruna Bagnato, L'Italia e la guerra d'Algeria (1954-1962) (Soveria Mannelli: Rubbettino, 2012), 309-10; Philippe Bourdrel, La dernière chance de l'Algérie française: du gouvernement socialiste au retour de de Gaulle, 1956-1958 (Paris: Albin 
Michel, 1996); Cantoni, Oily deals; Irwin M. Wall, France, the United States, and the Algerian War (Berkeley, CA: University of California Press, 2001).

48 Bagnato, L'Italia e la guerra d'Algeria, 309 et seq.

49 Cantoni, Oily deals.

50 Pierre Beyssade, La guerre d'Algérie: 1954-1962 (Paris: Éditions Planète, 1968); 'France's hard-won successes', Petroleum Press Service, February 1958.

51 Petroleum Press Service, April 1958.

52 Petroleum Press Service, April 1958; Petroleum Press Service, April 1961.

53 Petroleum Press Service, April 1961.

54 Cantoni, Oily deals.

55 Ibid.

56 'The Fifth Republic's oil inheritance', Petroleum Press Service, February 1959.

57 Ibid.

58 'Les illusions sahariennes de la France et ses ayants-droit', El Moudjahid, 15 November 1957 (translation by the author).

59 Ibid.

60 Gamal Abdel Nasser, The philosophy of the revolution (Cairo: S.O.P. Press, 1952).

61 'Pétrole et unité économique du Maghreb', El Moudjahid, 22 July 1958 (translation by the author).

62 'Mobilizing capital', Petroleum Press Service, November 1958.

63 Ibid.

64 Ibid.

65 AN, b. 19900317/8, fd. 2, Algérie 1957/64, secret, Note sDEcE, Le F.L.N. et le pétrole du Sahara, 16 April 1958 (FOIA no. 111,382). In Cantoni, Oily deals.

66 Petroleum Press Service, August 1958.

67 'Note du CCE au gouvernement Tunisien', El Moudjahid, 22 July 1958.

68 'Conclusion des pourparlers CCE-gouvernement Tunisien', El Moudjahid, 22 August 1958 (translation by the author).

69 Bernard Tricot to Louis Joxe, 'Essai de définition d'une position gouvernementale sur le Sahara', 10 April 1961; in Maurice Faivre, Les archives inédites de la politique algérienne, 1958-1962 (Paris: L'Harmattan, 2000), 337. On Tricot's role at the first Évian negotiations, see Redha Malek, L’Algérie à Évian: histoire des négociations secrètes, 1956-1962 (Paris: Seuil, 1995), 136-40. Cited in Cantoni, Oily deals.

70 'La bataille du Sahara', El Moudjahid, 25 June 1961.

71 Petroleum Press Service, August 1961.

72 See Bagnato, L'Italia e la guerra d'Algeria; and Mario Pirani, Poteva andare peggio: mezzo secolo di ragionevoli illusioni (Milan: Mondadori, 2012).

73 Mohamed Khelladi, 'Testimonianza', in Ambasciata d'Italia and Istituto Italiano di Cultura di Algeri (eds.), Enrico Mattei e l'Algeria: durante la Guerra Liberazione Nazionale (Algiers: Ambasciata d'Italia and Istituto Italiano di Cultura di Algeri, 2010), 57-8, 58. For an account by Abdelmadjid Chikhi (general director of the National Algerian Archives) of the help provided by ENI to the Algerian minister of armaments and general relations for the collection of data on the Algerian subsoil, see Abdelmadjid Chikhi, 'Gli Accordi di Évian', in ibid., 60-3, 62; see also Dahoud Ould Kablia, 'Enrico Mattei e la Rivoluzione Algerina', in ibid., 18-21, 19-20. These are mostly personal accounts, but a folder named Documents prepared for G.P.R.A. with view to Evian does survive in the archives: see Cantoni, Oily deals.

74 See Cantoni, Oily deals.

75 Pirani, Poteva andare peggio.

76 'The Sahara in dispute', Petroleum Press Service, August 1961.

77 Total Archives, Direction Générale et Directions Centrales; Accords et Contrats Pays: Algérie, Déclaration des principes relative à la coopération économique et financière, 1962.

78 'The French Sahara for Algeria', Petroleum Press Service, April 1962.

79 Petroleum Press Service, March 1962.

80 Cattan, The law of oil concessions.

81 Alain Beltran, A comparative history of national oil companies (Brussels: PIE Peter Lang, 2010).

82 Pirani, Poteva andare peggio. 
83 Kouzmine, Le Sahara algérien.

84 Claude Bourdet, 'Sahara, pas de pétrole sans paix', France observateur, 24 October 1957 (translation by the author).

85 Ibid.

86 Ibid.

\section{Chapter 4}

1 Glenn Richardson, Renaissance monarchy: the reigns of Henry VIII, Francis I and Charles V (London: Arnold, 2002), 197.

2 Robert J. Knecht, Renaissance warrior and patron: the reign of Francis I (Cambridge: Cambridge University Press, 1994), 559.

3 Paul Mus, Le destin de l'Union française: de l'Indochine à l'Afrique (Paris: Seuil, 1954).

4 See, for example, the discussion of 'inscription' governing the social logic of textual sources in Gabrielle M. Spiegel, 'Historicism, and the social logic of the text in the Middle Ages', Speculum, 65:1 (1990), 59-86.

5 Allan Megill, 'Recounting the past: "description", explanation, and narrative in historiography', American Historical Review, 94:3 (1989), 627-53, 653.

6 Ann Laura Stoler, Along the archival grain: epistemic anxieties and colonial common sense (Princeton, NJ: Princeton University Press, 2009), 1.

7 As Theodor Adorno argued, the rationality of positive forms (here referring to the historical present), is the 'quintessence of all the negations it contains': Theodor W. Adorno, Lectures on negative dialectics (Cambridge: Polity, 2008), 12-21.

8 Antoinette Burton, Archive stories: facts, fictions, and the writing of history (Durham, NC: Duke University Press, 2006), 9.

9 Stoler, Along the archival grain, 3.

10 In thinking about the inclusion of these research stories, I was strongly influenced by Arlette Farge's reflection on The allure of the archives (New Haven, CT: Yale University Press, 2013) and Lisa Jardine's discussion in Temptation in the archives: essays in golden age Dutch culture (London: UCL Press, 2015), as well as Burton's Archive stories.

11 David Anderson, "Mau Mau in the High Court and the "lost" British empire archives: colonial conspiracy or bureaucratic bungle?', Journal of Imperial and Commonwealth History, 39:5 (2011), 699-716, 713.

12 This necessarily invites comparison to Gayatri Spivak's influential piece 'Can the subaltern speak?', in Peter Simon (ed.), Norton anthology of theory and criticism (New York, NY: W. W. Norton, 2001), 2197-2207, 2207. Spivak famously stresses that 'it is important to acknowledge our complicity in the muting', and Richard Drayton has more recently echoed this by counselling contemporary historians to speak 'to and for those outside the tribe': Richard Drayton, 'Where does the world historian write from? Objectivity, moral conscience and the past and present of imperialism', Journal of Contemporary History, 46:3 (2011), 67185. Acknowledging these subaltern voices, and granting them the space to speak, is at times a task of acknowledging where the structures and assumptions of our enquiry have seen them silenced or marginalized. Importantly, this work cannot claim a grand representative measure. The voices it recovers are male and largely bound into the structures of colonial elites, whether obviously, in the accounts of an eminent philologist and a colonial official, or more subtly, in recovering the silenced voices of disgruntled students in the colonial education system. By collating these documents on conditionality, one of the first casualties is comprehensive coverage.

13 Seth Koven, The match girl and the heiress (Princeton, NJ: Princeton University Press, 2015), conclusion to ch. 2.

14 Walter Benjamin, 'On the concept of history', in Howard Eiland and Michael W. Jennings (eds.), Walter Benjamin: selected writings, vol. IV, 1938-1940 (Cambridge, MA: Harvard University Press, 2003), 389-400, 397. See also Lynn Hunt, Measuring time, making history (Budapest: Central European University Press, 2008), 91.

15 Todd Shepard, The invention of decolonization: the Algerian War and the remaking of France (Ithaca, NY: Cornell University Press, 2006), 5. 
16 Christopher E. Goscha, "'So what did you learn from war?” Violent decolonization and Paul Mus's search for humanity', South East Asia Research, 20:4 (2012), 569-93.

17 Recently cited, for example, by Ryo Ikeda in The imperialism of French decolonisation: French policy and the Anglo-American response in Tunisia and Morocco (Basingstoke: Palgrave Macmillan, 2015).

18 Stanley Hoffman, 'Mus (Paul) - "Le destin de l'Union française: de l'Indochine à l'Afrique": revue', Revue économique, 7:3 (1956), 503-4.

19 Daniel Hémery, 'Paul Mus et la décolonisation', in David Chandler and Christopher E. Goscha (eds.), L'espace d'un regard: l'asie de Paul Mus (1902-1969) (Paris: Les Indes savantes, 2006), 242-4.

20 Gary Wilder, Freedom time: negritude, decolonization, and the future of the world (Durham, NC: Duke University Press, 2015), 203.

21 Likewise, Mus had famously penned a letter to Témoignage chrétien in 1949 criticizing the use of torture in Indochina. See Daniel Hémery, 'Décoloniser la France: "le syndrome indochinois"', in Pascal Blanchard and Sandrine Lemaire (eds.), Culture impériale 1931-1961 (Paris: Autrement, 2004), 175-98.

22 Indeed, Mus diagnosed a moral crisis in France's dealing with her empire, informed by his close engagement with Vietnam. For an excellent and humane engagement with Mus' moral critiques, see Susan Bayly, 'Conceptualizing resistance and revolution in Vietnam: Paul Mus' understanding of colonialism in crisis', Journal of Vietnamese Studies, 4:1 (2009), 192-205.

23 Agathe Larcher-Goscha, 'Ambushed by history: Paul Mus and colonial France's "forced reentry” into Vietnam (1945-1954)', Journal of Vietnamese Studies, 4:1 (2009), 206-39, 217.

24 Interestingly, this speaks to Martin Thomas' assessment of British views on French colonial failings, aligning with his first order of perspective: French administrations suffered for their inflexibility, despite the occasional attempt to 'fudge and fix' around the margins. Martin Thomas, 'A path not taken? British perspectives on French colonial violence', in Larry J. Butler and Sarah Stockwell (eds.), The wind of change: Harold Macmillan and British decolonization (Basingstoke: Palgrave Macmillan, 2013), 159-79, 161-5.

25 Mus, Le destin de l'Union française, 223.

26 Paul Mus' colonial entanglement was long-running and ultimately tragic. His son was killed in Algeria in 1960, and he wrote movingly about that loss in Guerre sans visage: lettres commentées du sous-lieutenant Émile Mus (Paris: Seuil, 1961). An excellent insight into Mus' life can be found in David Chandler, 'Paul Mus (1902-1969): a biographical sketch', Journal of Vietnamese Studies, 4:1 (2009), 149-91.

27 Drayton, 'Where does the world historian write from?', 672.

28 Nathalie Ruz, 'La force du Cartiérisme', in Jean-Pierre Rioux (ed.), La guerre d'Algérie et les Français (Paris: Fayard, 1990), 328-36, 329.

29 Ruz, 'La force du Cartiérisme', 329.

30 It is worth noting that Cartier didn't coin the famous phrase 'the Corrèze before the Zambèze' but, rather, it was Jean Montalat (deputy for the Corrèze) who cited Cartier and used the phrase in a discussion in the National Assembly in June 1964. He cited it as one that had been popularized elsewhere: 'As we are discussing the aid which France gives to underdeveloped countries and certain neighbouring states, the temptation is great for me as Mayor of Tulle, according to a short and sweet slogan from the streets, to think about "the Corrèze before the Zambèze", and remind you of some old arguments. I won't do it. But allow me say today, and to my eyes the articles of Mr Raymond Cartier in Paris-Match put it best, that we need to remind the French people that in many areas - alas! - France is itself an underdeveloped country.' Journal Officiel, débats parlementaires Assemblée nationale, session of 10 June 1964, 1777.

31 Mus, Le destin de l'Union française, 53-6.

32 Ruz, 'La force du Cartiérisme', 329.

33 Gary Wilder, The French imperial nation-state: negritude and colonial humanism between the two world wars (Chicago, IL: University of Chicago Press, 2005), 30.

34 Edward Tangye-Lean, 'Information after imperialism', BBC Written Archive Centre, E2/655/1.

35 Frantz Fanon, A dying colonialism (New York, NY: Grove Press, 1967), 63-4.

36 Mus, Le destin de l'Union française, 157.

37 Ibid., 142.

38 Ibid., 145.

39 Goscha, 'So what did you learn from war?', 571. 
40 Mus, Le destin de l'Union française, 229.

41 Wilder, Freedom time, 166.

42 Paul Mus, 'Algérie: la faute de calcul', Le Monde, 25 April 1957.

43 Ibid.

44 Wilder, The French imperial nation-state, 8.

45 A useful example here is in the uncertain memory of Mus in Vietnam, as one who sought to hold back President Hô Chí Min, and not as an engaged scholar. Bayly, 'Conceptualizing resistance and revolution in Vietnam', 205.

46 Thomas, 'A path not taken?', 161-5.

47 Andrew W. M. Smith, 'Of colonial futures and an administrative Alamo: investment, reform and the loi cadre (1956) in French West Africa', French History, 28:1 (2014), 92-113.

48 I didn't.

49 Shepard, The invention of decolonization, 217.

50 Ibid., 100, 271-2.

51 Martin Thomas, 'Albert Sarraut, French colonial development, and the communist threat, 1919-1930', Journal of Modern History, 77:4 (2005), 917-55, 955.

52 Clifford Rosenberg, 'Albert Sarraut and republican radical thought', French Politics, Culture and Society, 20:3 (2002), 97-114, 102.

53 Peggy R. Sabatier, "Elite" education in French West Africa: the era of limits, 1903-1945', International Journal of African Historical Studies, 11:2 (1978), 247-66, 247.

54 Christopher E. Goscha, 'Introduction', in Vietnam: un état né dans la guerre 1945-1954 (Paris: Armand Collins, 2011), 1-20. Likewise, Mus engaged with Sarraut's colonial thought, finding him a hopeful but ultimately disappointingly conservative figure. See Larcher-Goscha, 'Ambushed by history', 225-32.

55 Martine Mougin, L’Afrique a l'école depuis 1945 jusqu'à la fin des années 90, unpublished thesis, Université Lumière Lyon 2, 2005, 28-9.

56 Note from directeur général de la jeunesse et des sports, Gaston Roux, 8 April 1955, Archives nationales [hereafter AN] 19870441/42.

57 Letter from Georges Drouet to René Billères, ministre de l'éducation nationale, 15 May 1956, AN 19870441/42.

58 'Rencontre avec...Stelio Farandijs', Global Local Forum, 19 June 2014, www.global-localforum.com/pages.asp?ref_page $=6119$ (accessed 15 July 2015)

59 La Pensée: revue du rationalisme moderne, no. 74 (1957), 118.

60 'Extraits des devoirs scolaires', nd., Archives nationales d'outre-mer [hereafter ANOM] 112 APOM 27.

61 The name is today popular in Cameroon, though the files themselves come from within the federation of AEF.

62 'Extraits des devoirs scolaires', nd., ANOM 112 APOM 27.

63 Ibid.

64 Wilder, The French imperial nation-state, 298-9.

65 Sabatier, 'The era of limits', 247.

66 Anthony D. Smith, Ethno-symbolism and nationalism: a cultural approach (London: Routledge, 2009), 64. This thesis is more broadly discussed in Elie Kedourie, Nationalism (London: Hutchinson, 1960), especially in the introduction.

67 Smith, Ethno-symbolism and nationalism, 55.

68 The last note in square brackets is quoted from the text, and is not my observation: 'Extraits des devoirs scolaires', nd., ANOM 112 APOM 27.

69 Elikia M'Bokolo, 'Forces sociales et idéologies dans la décolonisation de l'A.E.F.', Journal of African History, 22:3 (1981), 393-407, 401.

70 Martin Thomas, Bob Moore and Larry J. Butler, Crises of empire: decolonization and Europe's imperial states, 1918-1975, 2nd edn (London: Bloomsbury, 2015), 167.

71 Chauvet had actually succeeded Bernard Cornut-Gentille, the author of the third source in this chapter.

72 M'Bokolo, 'Forces sociales et idéologies', 399.

73 As Robert Gildea notes, '[N]ot...all réfractaires became maquisards; some simply lay low.' See Robert Gildea, Fighters in the shadows: a new history of the French Resistance (London: Faber \& Faber, 2015), 296-9.

74 Tony Chafer, The end of empire in French West Africa: France's successful decolonization? (Oxford: Berg, 2002), 138 n. 4. 
75 Bernard Cornut-Gentille, 'Les problèmes politiques de l'A.O.F.' [report, probably dated 1954], 14

76 Ibid., 38.

77 Thomas et al., Crises of empire, 139.

78 Shipway, Decolonization and its impact, 89.

79 Martin Thomas, Fight or flight: Britain, France and their roads from empire (Oxford: Oxford University Press, 2014), 88.

80 Thomas Hodgkin, Nationalism in colonial Africa (London: Frederick Muller, 1956), 10.

81 For more on the loi cadre, see Smith, 'Of colonial futures and an administrative Alamo'; and, Martin Shipway, 'Gaston Defferre's Loi-Cadre and its application 1956/57: the last chance for a French African “empire-state” or blueprint for decolonisation?' in: Tony Chafer and Alexander Keese (eds.), Francophone Africa at fifty (Manchester: Manchester University Press, 2013), 15-29.

82 Cornut-Gentille, 'Les problèmes politiques de l'A.O.F.', 4.

83 Frederick Cooper, Decolonization and African society: the labor question in French and British Africa (Cambridge: Cambridge University Press, 1996), 424-5.

84 After Cornut-Gentille's time as Governor General of AOF ended, he would remain close to the Gaullist government until the end of the Algerian War, when he broke with Gaullism at the same time as Jacques Soustelle (who had also been Governor General) in 1960.

85 Cornut-Gentille, 'Les problèmes politiques de l'A.O.F.', 2.

86 'Note pour le ministre', Direction des Affaires Politiques, 11 February 1957, ANOM, AFFPOL-3512.

87 Frederick Cooper, Citizenship between empire and nation: remaking France and French Africa, 1945-1960 (Princeton, NJ: Princeton University Press, 2014), 288.

88 'Note pour le ministre', Direction des Affaires Politiques, 11 February 1957, ANOM, AFFPOL-3512.

89 Cornut-Gentille, 'Les problèmes politiques de l'A.O.F.', 38.

90 Léopold Senghor, 'Pour une solution fédéraliste', La Nef (June 1955), 148-61, quoted in Wilder, Freedom time, 156.

91 Indeed, Cornut-Gentille went on to become a deputy allied to the Gaullists, until he split with them over the Algerian War.

92 Jean-Pierre Bat, 'Jacques Foccart: eminence grise for African affairs', in Chafer and Keese, Francophone Africa at fifty, 135-54.

93 See also the various contributions to the 'AHR roundtable: the archives of decolonization', American Historical Review, 120:3 (2015), 844-950.

94 Shepard, The invention of decolonization, 5.

\section{Chapter 5}

1 Frederick Cooper, Citizenship between empire and nation: remaking France and French Africa, 1945-1960 (Princeton, NJ: Princeton University Press, 2014). See also Samuel Moyn, 'Fantasies of federalism', Dissent, 62:1 (2015), 145-51.

2 Lynn Hunt, Inventing human rights: a history (New York, NY: W. W. Norton, 2007).

3 Samuel Moyn, The last utopia: human rights in history (Cambridge, MA: Belknap Press of Harvard University Press, 2010). It is also worth noting that, in their sweeping account of the contemporary world, Hardt and Negri similarly speak of human rights as a discourse of universalism that serves the novel 'empire' of their title: Michael Hardt and Antonio Negri, Empire (Cambridge, MA: Harvard University Press, 2000).

4 Jan Eckel and Samuel Moyn (eds.), The breakthrough: human rights in the 1970s (Philadelphia, PA: University of Pennsylvania Press, 2014).

5 Simon Stevens, 'Why South Africa? The politics of anti-apartheid activism in Britain in the long 1970s', in Eckel and Moyn, The breakthrough, 204-25.

6 Moyn, The last utopia, 118-19.

7 Marco Duranti, 'Curbing Labour's totalitarian temptation: European human rights law and British postwar politics', Humanity: An International Journal of Human Rights, Humanitarianism, and Development, 3:3 (2012), 361-83. 
8 A. W. Brian Simpson, Human rights and the end of empire: Britain and the genesis of the European Convention (Oxford: Oxford University Press, 2001); Charles Parkinson, Bills of rights and decolonization: the emergence of domestic human rights instruments in Britain's Overseas Territories (Oxford: Oxford University Press, 2007).

9 Roland Burke, Decolonization and the evolution of international human rights (Philadelphia, PA: University of Pennsylvania Press, 2010), 2.

10 Michael Scott, Civilization in Africa (London: Fellowship of Reconciliation, 1952), 4.

11 Trevor Huddleston to John Collins, 20 February 1953, Collins Papers, Ms 3300, Lambeth Palace Library.

12 Christopher Saunders, 'Michael Scott and Namibia', African Historical Review, 39:2 (2007), 25-40; Carol Anderson, 'International conscience, the Cold War, and apartheid: the NAACP's alliance with the Reverend Michael Scott for South West Africa's liberation, 1946-1951', Journal of World History, 19:3 (2008), 297-325; Roger S. Clark, 'The International League for Human Rights and South West Africa 1947-1957: the human rights NGO as catalyst in the international legal process', Human Rights Quarterly, 3:4 (1981), 101-36; Ryan M. Irwin, 'Apartheid on trial: South West Africa and the International Court of Justice, 1960-66', International History Review, 32:4 (2010), 619-42.

13 Lewis John Collins, Faith under fire (London: Frewin, 1966); Denis Herbstein, White lies: Canon John Collins and the secret war against apartheid (Oxford: James Currey, 2004).

14 Helen Roberts, 'Witness: the origins of justice', Paragon Review (1998), www.hull.ac.uk/ oldlib/archives/paragon/1997/witness.html. See also Tom Buchanan, "The truth will set you free": the making of Amnesty International', Journal of Contemporary History, 37:4 (2002), 575-97.

15 On human rights in the Hola Camp debate, see, for example, Hansard, House of Commons Debates, 27 July 1959, vol. 610, cc. 181-262. See also David Anderson, Histories of the hanged: Britain's dirty war in Kenya and the end of the empire (London: Weidenfeld \& Nicolson, 2005); and Caroline Elkins, Imperial reckoning (London: Henry holt, 2005). On the impact of these events on British policy-makers, see Parkinson, Bills of rights, 33-6.

16 Guardian, 5 May 1960.

17 Parkinson, Bills of rights, 270.

18 R. A. Butler, Hansard, House of Commons Debates, 7 April 1960, vol. 621, cc. 563-5.

19 Saul Dubow, 'Macmillan, Verwoerd, and the 1960 "wind of change" speech', Historical Journal, $54: 4$ (2011), 1087-114.

20 Moyn, The last utopia, 129.

21 Ibid., 130-1; Buchanan, "'The truth will set you free"'; on the formation of Amnesty, see also Ann Marie Clark, Diplomacy of conscience: Amnesty International and changing human rights norms (Princeton, NJ: Princeton University Press, 2001), 3-20.

22 On Benenson and justice, see Roberts, 'Witness: the origins of justice'. For a discussion of the role of Quaker movements in early anti-apartheid activities, see Robert Skinner, The foundations of anti-apartheid: liberal humanitarians and transnational activists in Britain and the United States, c. 1919-64 (Basingstoke: Palgrave Macmillan, 2010), 91-3.

23 Peter Benenson to Movement for Colonial Freedom, nd. [1963], Movement for Colonial Freedom Papers, Box 20/AFF 4, School of Oriental and African Studies, London.

24 See Randall Williams, Divided world: human rights and its violence (Minneapolis, MN: University of Minnesota Press, 2010); see also Clark, Diplomacy of conscience, 14.

25 Oliver Tambo, 'Appeal for action to stop repression and trials in South Africa', presented to the Special Political Committee of the UN General Assembly, New York, 8 October 1963, www.sahistory.org.za/archive/oliver-tambo-speeches-1960-1964 (accessed 17 July 2013).

26 UN General Assembly Resolution 1881, 11 October 1963.

27 Arianna Lissoni, 'Anti-apartheid protest vs real politik: the Anti-Apartheid Movement and British policy towards South Africa during the Rivonia Trial', paper presented at the conference 'International anti-apartheid movements in South Africa's freedom struggle: lessons for today', University of KwaZulu-Natal, Durban, South Africa, 11 October 2004.

28 Ibid. See also Kenneth S. Broun, Saving Nelson Mandela: the Rivonia Trial and the fate of South Africa (Oxford: Oxford University Press, 2012).

29 Anti-Apartheid Movement, 'Annual report' (1964). 
30 The Times, 15 May 1963. The human impact of the 90-day law was described in a Penguin Special authored by the radical activist Ruth First. See Ruth First, 117 Days (London: Penguin Books, 1965).

31 Saul Dubow, South Africa's struggle for human rights (Athens, OH: Ohio University Press, 2012), 81-3.

32 Anthony S. Matthews and Ronald C. Albino, 'Permanence of the temporary: an examination of the 90- and 180-day Detention Laws', South African Law Journal, 83:1 (1966), 16-43.

33 'Minutes, meeting of IDAF \& World Campaign for the Release of South African Political Prisoners', 23 February 1967, Anti-Apartheid Movement Papers, Mss AAM 1778, Bodleian Library of Commonwealth and African Studies, Oxford.

34 Burke, Decolonization, 90-1. See also Paul Gordon Lauren, The evolution of international human rights: visions seen (Philadelphia, PA: University of Pennsylvania Press, 2003).

35 'Suggestions to be placed before the Special Committee on Apartheid by the World Campaign for the Release of South African Political Prisoners', July 1967, Anti-Apartheid Movement Papers, Mss AAM 1779.

36 Robert M. Resha, 'Paper on apartheid', presented on behalf of the African National Congress of South Africa to the UN human rights seminar on apartheid, Brasília (1966).

37 On Kitwe, see Ryan M. Irwin, Gordian knot: apartheid and the unmaking of the liberal world order (Oxford: Oxford University Press, 2012), 139-44.

38 Ingrid Nifosi, The UN special procedures in the field of human rights (Holmes Beach, FL: Gaunt, 2005), 67.

39 Ibrahima Boye to Dennis Brutus, 15 April 1968, Anti-Apartheid Movement Papers, Mss AAM 1782.

40 Moyn, The last utopia, 126.

41 Joost de Blank, 'Human Rights Year: preparing our programme' (July 1967), Movement for Colonial Freedom Papers, Box 22/AFF 10. Unfortunately, de Blank died in January 1968 and was unable to see the plans come to fruition.

42 Rendani Moses Ralinala, Jabulani Sithole, Gregory Houston and Bernard Magubane, 'The Wankie and Sipolilo campaigns', in South African Democracy Education Trust (ed.), The road to democracy in South Africa, vol. I, 1960-1970 (Cape Town: Zebra Press, 2004), 479-540; see also Stephen Ellis, External mission: the ANC in exile, 1960-1990 (London: Hurst, 2012), 62-4.

43 Colin Legum, 'Africa's embattled whites line up', The Observer, 1 October 1967, 8.

44 Moyn, The last utopia, 2-3, 126-7.

45 Manouchehr Ganji, United Nations' study of apartheid and racial discrimination in southern Africa: report of the Special Rapporteur (New York, NY: United Nations, 1967).

46 Burke, Decolonization, 107.

47 United Nations, Final act of the International Conference on Human Rights: Teheran, 22 April to 13 May 1968 (New York, NY: United Nations, 1968), 6-7. For a view of the contrasting tone of debate around sanctions in 1964, see Ronald Segal (ed.), Sanctions against South Africa (Harmondsworth: Penguin Books, 1964).

48 Dennis Brutus, 'Report to IDAF annual conference', 25 April 1969, Anti-Apartheid Movement Papers, Mss AAM 1778.

49 UN, Final act of the International Conference, 7, 13, 18.

50 Abdul Minty, 11 September 1968, Movement for Colonial Freedom Papers, Box 20/AFF 4.

51 Abdul Minty, 'Human rights in Rhodesia', International Year for Human Rights Newsletter, October 1968.

52 Irwin, Gordian knot, 128.

53 Roland Burke, 'From individual rights to national development: the first UN International Conference on Human Rights, Tehran, 1968', Journal of World History, 19:3 (2008), 275-96, 276.

54 See Burke, Decolonization. On the Non-Aligned Movement and apartheid in the 1960s and 1970s, see also Peter Willetts, The Non-Aligned Movement: the origins of a Third World alliance (New York, NY: Nichols, 1978), 151-201.

55 Maurice Cranston, What are human rights? (London: Bodley Head, 1973), 73.

56 Burke, 'From individual rights', 288-94.

57 Ibid., 283-4. See also 'Address delivered by His Imperial Majesty the Shahinshah Aryamehr', in UN, Final act of the International Conference, 34.

58 Burke, 'From individual rights', 296; see also Burke, Decolonization, 109-10. 
59 Roland Burke. "The compelling dialogue of freedom": human rights at the Bandung Conference', Human Rights Quarterly, 28:4 (2006), 947-65, 954-5.

60 Africa Digest, February 1968, 1.

61 Rupert Emerson, 'The fate of human rights in the Third World', World Politics, 27:2 (1975), 201-26, 217.

62 'World Peace Brigade submission to UN Special Commission on Colonialism', 5 June 1962, Muste Papers, Reel 89-39, Africa Freedom Action, Swarthmore College Peace Collection.

63 Burke, Decolonization, 109.

64 Haslemere Committee, 'The Haslemere Declaration' (London: Haslemere Committee, 1968).

65 Ibid., 6.

66 Ibid., 4.

67 Ibid., 17.

68 Moyn, The last utopia, 111.

69 Hélder Câmara, Spiral of violence (London: Sheed \& Ward, 1971).

70 Ibid., 38.

71 Michael N. Barnett, Empire of humanity: a history of humanitarianism (Ithaca, NY: Cornell University Press, 2011).

72 Robert Hutchinson, 'Southern Africa: notes towards a Haslemere campaign', 18 June 1969, Anti-Apartheid Movement Papers, Mss AAM 885.

73 North London Haslemere Group. 'To local groups of socialist and radical organisations', 5 January 1970, Anti-Apartheid Movement Papers, Mss AAM 885. On the Barclays campaign, see Nerys John, 'The campaign against British bank involvement in apartheid South Africa', African Affairs, 99:396 (2000), 415-33.

74 Adam Lent, British social movements since 1945: sex, colour, peace and power (Basingstoke: Palgrave Macmillan, 2001), 112-13.

75 Ruth Addison to Anti-Apartheid Movement, 29 July 1970, Anti-Apartheid Movement Papers, Mss AAM 1436.

76 See Moyn, The last utopia, 195-201.

77 Burke, Decolonization, 149.

\section{Chapter 6}

1 Kenneth Bradley, A career in the Oversea Civil Service, 2nd edn (London: Stationery Office, 1955), 62. His book Diary of a district officer (London: Macmillan, 1942) became especially popular with potential applicants after the war, and was often cited as a motivating force behind an application.

2 The literature on the cultural depiction of empire in British culture is wide, and particularly well covered in the Manchester University Press 'Studies in Imperialism' series. See, for instance, John MacKenzie (ed.), Imperialism and popular culture (Manchester: Manchester University Press, 1986). See also Jonathan Rose, The intellectual life of the British working classes, 2nd edn (New Haven, CT: Yale University Press, 2010), 321-64; and Wendy Webster, Englishness and empire 1939-1965 (Oxford: Oxford University Press, 2005).

3 Bernard Porter, The absent-minded imperialists: empire, society, and culture in Britain (Oxford: Oxford University Press, 2004), 40-63; Andrew Thompson, The empire strikes back? The impact of imperialism on Britain from the mid-nineteenth century (Harlow: Pearson Longman, 2005), 17-29.

4 Kenneth Bradley, The Colonial Service as a career (London: Stationery Office, 1950).

5 'Towards a retrospective record', Overseas Service Pensioners Association memory project (2000-2), five boxes, the Bodleian Library of Commonwealth and African Studies, Oxford. For a summary of this project, see Anthony Kirk-Greene, Symbol of authority: the British district officer in Africa (London: I. B. Tauris, 2006), 308-9.

6 'Appointments in recruitment for service overseas: future policy', in Parliamentary Accounts and Papers, vol. XXI, 1961-62 (London: Stationery Office, 1963), 755-85.

7 Christopher Prior, Exporting empire: Africa, colonial officials and the construction of the imperial state c. 1900-39 (Manchester: Manchester University Press, 2013), 18-28.

8 'Colonial Service recruitment (expatriate staff) report', January 1952, Cambridge University Archives [hereafter CUA], CDEV/4/5. 
9 Marcus Collins, 'The fall of the English gentleman: the national character in decline, c. 1918-70', Historical Research, 75:187 (2002), 90-111, 106.

10 Georgina Brewis, A social history of student volunteering: Britain and beyond, 1880-1980 (Basingstoke: Palgrave Macmillan, 2014), 176-86; Matthew Hilton, James McKay, Nicholas Crowson and Jean-Francois Mouhot, The politics of expertise: how NGOs shaped modern Britain (Oxford: Oxford University Press, 2013), 74.

11 Joseph Morgan Hodge, 'British colonial expertise, postcolonial careering and the early history of international development', Journal of Modern European History, 8:1 (2010), 24-46. For an interesting comparison with the French case, see Véronique Dimier, 'For a new start: resettling French colonial administrators in the Prefectoral Corps', Itinerario, 28:1 (2004), 49-66.

12 Studies of the making of colonial policy during the post-war period abound; among the best are Phillip Murphy, Party politics and decolonization: the Conservative Party and British colonial policy in tropical Africa, 1951-1964 (Oxford: Clarendon Press, 1995); Frank Heinlein, British government policy and decolonisation, 1945-1963: scrutinizing the official mind (London: Frank Cass, 2002); and Ronald Hyam, Britain's declining empire: the road to decolonisation 19181968 (Cambridge: Cambridge University Press, 2006).

13 For example, Correlli Barnett, The audit of war: the illusion and reality of Britain as a great nation (London: Macmillan, 1986). For a persuasive debunking of these arguments, see David Edgerton, Warfare state: Britain, 1920-1970 (Cambridge: Cambridge University Press, 2005); and Jim Tomlinson, 'The decline of the empire and the economic "decline" of Britain', Twentieth Century British History, 14:3 (2003), 201-21.

14 Although frequently reduced to 'maximalists versus minimalists', the field is far richer than this dichotomy suggests. For a recent reflection, see John MacKenzie, 'The British empire: ramshackle or rampaging? A historiographical reflection', Journal of Imperial and Commonwealth History, 43:1 (2015), 99-124.

15 Ann Laura Stoler and Frederick Cooper, 'Between metropole and colony: rethinking a research agenda', in Ann Laura Stoler and Frederick Cooper (eds.), Tensions of empire: colonial cultures in a bourgeois world (Berkeley, CA: University of California Press, 1997), 1-58; Catherine Hall and Sonya Rose (eds.), At home with the empire: metropolitan culture and the imperial world (Cambridge: Cambridge University Press, 2006).

16 Stuart Ward (ed.), British culture and the end of empire (Manchester: Manchester University Press, 2001); Webster, Englishness and empire; Andrew Thompson (ed.), Britain's experience of empire in the twentieth century (Oxford: Oxford University Press, 2011).

17 Bill Schwarz, Memories of empire, vol. I, The white man's world (Oxford: Oxford University Press, 2011); Jordanna Bailkin, The afterlife of empire (Berkeley, CA: University of California Press, 2012); Camilla Schofield, Enoch Powell and the making of postcolonial Britain (Cambridge: Cambridge University Press, 2013).

18 The classic study of the Colonial Service and, in particular, the motivation behind an application is Robert Heussler, Yesterday's rulers: the making of the British Colonial Service (Syracuse, NY: Syracuse University Press, 1963). Many of Heussler's romanticized assumptions are debunked in Nile Gardiner, Sentinels of empire: the British Colonial Administrative Service, 1919-54, unpublished PhD thesis, Yale University (1998). For a comparative survey of all imperial civil services, see Anthony Kirk-Greene, Britain's imperial administrators, 1858-1966 (Basingstoke: Macmillan, 2000).

19 Kirk-Greene, Britain's imperial administrators, 7-22; Elizabeth Buettner, Empire families: Britons and late imperial India (Oxford: Oxford University Press, 2004); Prior, Exporting empire, passim.

20 A few outstanding studies include Bruce Berman, Control and crisis in colonial Kenya: the dialectic of domination (Oxford: James Currey, 1990); Joanna Lewis, Empire state-building: war and welfare in Kenya 1925-52 (Oxford: James Currey, 2001); and Emma Hunter, Political thought and the public sphere in Tanzania (Cambridge: Cambridge University Press, 2015), especially chs. 2 and 3.

21 Larry J. Butler and Sarah Stockwell (eds.), The wind of change: Harold Macmillan and British decolonization (Basingstoke: Palgrave Macmillan, 2013).

22 Martin Shipway, Decolonization and its impact: a comparative approach to the end of the colonial empires (Malden, MA: Blackwell, 2008), 8-16.

23 Ashley Jackson, 'Empire and beyond: the pursuit of overseas national interests in the late twentieth century', English Historical Review, 123:499 (2007), 1350-66. 
24 Elizabeth Buettner, Europe after empire: decolonization, society, and culture (Cambridge: Cambridge University Press, 2016).

25 Bailkin, Afterlife of empire, 3-6.

26 On the structure of the Colonial Service, see Anthony Kirk-Greene, On Crown service: a history of HM Colonial and Overseas Civil Service, 1837-1997 (London: I. B. Tauris, 1999).

27 'Colonial affairs: extracts from a speech by the Secretary of State for the colonies (Oliver Stanley) in the House of Commons, 13 July 1943', in Andrew N. Porter and Anthony J. Stockwell (eds.), British imperial policy and decolonization 1938-64, vol. I, 1938-51 (Basingstoke: Palgrave Macmillan, 1987), 156-67, 156.

28 Heinlein, British government policy and decolonisation, 27-32.

29 Joseph Morgan Hodge, Triumph of the expert: agrarian doctrines of development and the legacies of British colonialism (Athens, OH: Ohio University Press, 2007), 207-53.

30 D. A. Low and John Lonsdale, 'Introduction: towards the new order, 1945-1963', in D. A. Low and Alison Smith (eds.), History of East Africa, vol. III (Oxford: Clarendon Press, 1976), 1-63, 13; Anthony Kirk-Greene, A biographical dictionary of the Colonial Service, 1936-1966 (London: H. Zell, 1991), vii.

31 Sabine Clarke, 'A technocratic imperial state? The Colonial Office and scientific research, 1940-1960', Twentieth Century British History, 18:4 (2007), 453-80.

32 Frederick Cooper, 'Reconstructing empire in British and French Africa', Past and Present, 210:6 (2011), 196-210.

33 Heussler, Yesterday's rulers, 18-20.

34 Sir Ralph Furse, Aucuparius: recollections of a recruiting officer (Oxford: Oxford University Press, 1962), 228; H. John Field, Toward a programme of imperial life; the British empire at the turn of the twentieth century (Oxford: Clio Press, 1982), 229-40.

35 Collins, The fall of the English gentleman, 92-5.

36 Peter J. Cain, 'Empire and the languages of character and virtue in the later Victorian and Edwardian Britain', Modern Intellectual History, 4:2 (2007), 249-73.

37 Peter Mandler, The English national character: the history of an idea from Edmund Burke to Tony Blair (New Haven, CT: Yale University Press, 2006), 135-38; Martin Francis, 'Tears, tantrums, and bared teeth: the emotional economy of three Conservative prime ministers, 1951-1963', Journal of British Studies, 41:3 (2002), 354-87, 368-72.

38 Maria Misra, 'Colonial officers and gentlemen: the British empire and the globalization of "tradition"', Journal of Global History, 3:2 (2008), 135-61; Kathryn Tidrick, Empire and the English character: the illusion of authority (London: Tauris Parke, 1990), ch. 6.

39 Hyam, Britain's declining empire, 11.

40 Anthony Kirk-Greene, 'The Colonial Service in the novel', in John Smith (ed.), Administering empire: the British Colonial Service in retrospect (London: University of London Press, 1999), 19-48; Anthony Aldgate and Jeffrey Richards, Best of British: cinema and society from 1930 to the present (London: I. B. Tauris, 1999), 20-36.

41 Clarke, A technocratic imperial state?, 454.

42 Christopher Prior, 'A brotherhood of Britons? Public schooling, esprit de corps and colonial officials in Africa, c.1900-1939', History, 98:330 (2013), 174-90.

43 Still among the best studies of female colonial officers, Helen Callaway, Gender, culture and empire: European women in colonial Nigeria (Chicago, IL: University of Illinois Press, 1987).

44 Chris Jeppesen, "'Sanders of the River, still the best job for a British boy": recruitment to the Colonial Administrative Service at the end of empire', Historical Journal, 59:2 (2016), 469-508.

45 The reports for all cadets who undertook their training at Cambridge from 1946 to 1963, as well as some interview reports, are held in the $\mathrm{CDEV} / 3$ series, Cambridge University Archives. Conditions of access demand that all references are kept anonymous. Where I quote directly from a report or interview summary I give the year and folder, while more general points must be taken as reflective of overall tone.

46 Memo on 'The Colonial Service - my job', lecture evening Cambridge, 22 February 1952, CUA, $\mathrm{CDEV} / 4 / 5$.

47 Colonial Service recruitment poster, January 1955, CUA, CDEV/4/6.

48 'Colonial Office circular on recruitment and publicity at schools', August 1956, CUA, CDEV/4/7.

49 Colonial Office, Post-war training for the Colonial Service: report of a committee appointed by the Secretary of State for the colonies (London: Stationery Office, 1945); Véronique Dimier, 
'Three universities and the British elite: a science of colonial administration in the UK', Public Administration, 84:2 (2006), 337-66.

50 Colonial Office interview summary, May 1961, CUA, CDEV/3/29/A; D. Joy (Colonial Administrative Service [CAS], Northern Rhodesia, 1956-63), 'Towards a retrospective record', Box 3.

51 Charles Jeffries, Colonial Office memorandum 'Job analysis for the Colonial Service' (1943), Furse Papers, Bodleian Library of Commonwealth and African Studies, Oxford, SS.Brit. Emp.S.415/4/4/7.

52 J. Howard (Cambridge Devonshire course supervisor), January 1953, CUA, CDEV/1/4/5.

53 Colonial Office interview reports, 1958, CUA, CDEV/3/26.

54 A. H. Gardner-Brown (Cambridge Devonshire course supervisor) to T. R. Henn (Fellow St Catharine's, Cambridge), 21 April 1950, CUA, CDEV/1/4/5.

55 Colonial Office interview report, 3 May 1961, CUA, CDEV/3/29/A.

56 H. B. Shaw (headmaster Hulme Grammar School, Oldham), 31 March 61, CUA, CDEV/3/28/ B.

57 Dr D. C. M. Yardley, 17 March 1960, CUA, CDEV/3/28/B.

58 Mike Savage and Andy Miles, 'The strange survival story of the English gentleman, 1945-2010', Cultural and Social History, 9:4 (2012), 595-612, especially 597-98; Frank Mort, Capital affairs: London and the making of the permissive society (New Haven, CT: Yale University Press, 2010), 72-3.

59 David Anderson, 'Guilty secrets: deceit, denial, and the discovery of Kenya's "migrated archive"', History Workshop Journal, 80:1 (2015), 142-60, 147.

60 Mandler, The English national character, 197-215. See also Max Jones, "National hero and very queer fish": empire, sexuality and the British remembrance of General Gordon, 1918-72', Twentieth Century British History, 26:2 (2015), 175-202, 187-94.

61 Martin Francis, 'A flight from commitment? Domesticity, adventure and the masculine imaginary in Britain after the Second World War', Gender and History, 19:1 (2007), 163-85, 169; Kirk-Greene, Symbol of authority, 23.

62 H. H. McCleery to R. C. H. Greig (Colonial Office), 22 March 1956, CUA, CDEV/4/6.

63 McCleery to George Baker (CAS Tanganyika), 21 December 1955, CUA, CDEV/4/6.

64 McCleery to Revd D. P. Hardy, College Tutor, 24 October 1956, CUA, CDEV/4/7.

65 McCleery to A. D. Garson, 6 November 1959, CUA, CDEV/4/7.

66 Ann Ewing, 'The Indian Civil Service 1919-1924: service discontent and the response in London and in Delhi', Modern Asian Studies, 18:1 (1984), 33-53.

67 A. H. M. Kirk-Greene and R. W. H. Du Boulay, 'Memorandum on recruiting for the Administrative Service of northern Nigeria at Oxford and Cambridge Universities 1955-56', 1 August 1956, CUA, CDEV/4/7.

68 Francis Greenland to McCleery, 20 November 1959, CUA, CDEV/4/7.

69 McCleery to Colonial Office, 'Report on recruitment evening', 27 January 1959, CUA, CDEV/ 4/7; Oxford University Appointments Board annual report (1961), Oxford Careers Service Archive, Oxford University Archives, Bodleian Library Oxford, CR1/8/61, 5.

70 Cambridge University Appointments Board annual report (1962), CUA, APTB/1/68.

71 Political and Economic Planning, Graduate employment: a sample survey, September 1956 (London: Political and Economic Planning, 1956).

72 'Go overseas, young man', The Times, 28 September 1955, 9.

73 Letter of resignation from serving DO in Kenya to Secretary of State for the colonies, 28 February 1961, CUA, CDEV/3/28.

74 Mike Savage, 'Affluence and social change in the making of technocratic middle-class identities: Britain, 1939-55', Contemporary British History, 22:4 (2008), 457-476, 470-1.

75 Edgerton, Warfare state, 172-4.

76 Webster, Englishness and empire, 184-5; Lynne Segal, 'Look back in anger: men in the fifties', in Rowena Chapman and Jonathan Rutherford (eds.), Male order: unwrapping masculinity (London: Lawrence \& Wishart, 1987), 68-96, 83; Francis, Tears, tantrums and bared teeth, 380-3.

77 Anthony Sampson, Anatomy of Britain (London: Hodder \& Stoughton, 1962), 317-19.

78 Elwyn Thomas, Night of the Jassies (London: Jonathan Cape, 1959), quoted in Kirk-Greene, 'The Colonial Service in the novel', 28.

79 For a thoughtful account of one 1950s grammar school recruit's career in Tanganyika, see Donald Barton, An affair with Africa: Tanganyika remembered (Hertford: AuthorsOnline, 2004). 
80 McCleery to establishment officer, Tanganyika, 13 July 1956, CUA, CDEV/4/7.

81 David Turner, The old boys: the decline and rise of the public school (New Haven, CT: Yale University Press, 2015), 193-219.

82 See James A. Mangan, The games ethic and imperialism: aspects of the diffusion of an ideal (Harmondsworth: Viking, 1986).

83 'Headmaster of Wellington College, speech day (1956)', The Wellingtonian, July 1956, 626.

84 Quoted in Richard Vinen, National Service: a generation in uniform 1945-1963 (London: Penguin Books, 2014), 309, 511 fn 6.

85 For example, The Wellingtonian, March 1959, 604.

86 For example, 'Jazz over classical music' (Wellington, December 1956); 'Without reform the public schools deserve to die' (Charterhouse, June 1954; Wellington, March 1957; Westminster, April 1959); teenage culture (Wellington, March 1958); the power of the press (Charterhouse, June 1955; Charterhouse, March 1958); or the nuclear deterrent (Charterhouse, July 1958). All took precedence over the end of empire.

87 The Haileyburian, July 1958, 7:XXXII, 52; The Wellingtonian, July 1960, 293; King Edward's School Chronicle (King Edward's, Birmingham), September 1963, 61.

88 Speech by Michael Ramsey, Archbishop of Canterbury at Haileybury, The Haileyburian, July 1962, 780:XXXII.

89 The Haileyburian, July 1957, 755:XXXI.

90 'Sixth form career motivations: some careers in administration', ISCO Bulletin, 3 April 1969, 19-29.

91 Georgina Brewis, 'Youth in action? British young people and voluntary service, 1958-70', in Melanie Oppenheimer and Nicholas Deakin (eds.), Beveridge and voluntary action in Britain and the wider British world (Manchester: Manchester University Press, 2011), 94-108, 96-8.

92 Michael Adams, Voluntary Service Overseas: the story of the first ten years (London: Faber, 1969), 38-9, 80.

93 Alec Dickson, 'Barriers to voluntary action', Commonwealth Challenge, 6:1 (1957), 86-95, 92; Godfrey Golzen and Margaret Stewart, Working abroad: the Daily Telegraph guide to working and living overseas (London: K. Page, 1977); Bailkin, Afterlife of empire, 55-94.

94 Orion, 'Youth and the Commonwealth', Commonwealth Challenge, 6:4 (July 1958), 1-7, 2.

95 Alec Dickson, 'Barriers to voluntary action'; Alec Dickson, 'Young man's challenge', Corona Journal, 11:6 (1959), 213-16.

96 The Sunday Times, 26 April 1959, 10.

97 Tom Rice, 'From the inside: the Colonial Film Unit and the beginning of the end', in Lee Grieveson and Colin MacCabe, Film and the end of empire (Basingstoke: Palgrave Macmillan, 2011), 135-54.

98 Details taken from H. Charles Swaisland, 'Alec Dickson', Oxford Dictionary of National Biography (Oxford: Oxford University Press, 2004) (online version).

99 Colonial Office, Education for citizenship in Africa (London: Stationery Office, 1948); 'Man o'War Bay', Commonwealth Challenge, 6:1 (1957), 46-52.

100 Mora Dickson (ed.), Alec Dickson: a chance to serve (London: Dennis Dobson, 1976), 19-90. Dickson covers her husband's early life and career using his own articles to shape the text.

101 Mora Dickson, A world elsewhere: Voluntary Service Overseas (London: Dennis Dobson, 1964), 13-14.

102 Dick Bird, Never the same again: a history of VSO (Cambridge: Lutterworth Press, 1998), 16.

103 Alec Dickson quoted in Bird, Never the same again, 18.

104 Alec Dickson, 'Our youth - and yours', Corona Journal, 10:1 (1958), 19-20.

105 Dickson (ed.), Alec Dickson: a chance to serve, 91-4.

106 Adams, Voluntary Service Overseas, 43.

107 Colonial Office minutes, the National Archives [hereafter TNA], CO/96/811.

108 Bishop of Portsmouth to The Sunday Times, 23 March 1958.

109 The Sunday Times, 23 March 1958.

110 The Economist, 21 April 1962.

111 'Boy volunteers return home', The Times, 29 September 1959, 6.

112 G. L. Stephenson to W. J. Smith (Department of Technical Cooperation), 13 November 1961, TNA, OD/10/3. 
113 Donald Wainwright, The volunteers: thestory ofoverseas voluntary service (London: Macdonald, 1965), 34.

114 On Chadwick, see Ben Page, “"And the Oscar goes to... Daybreak in Udi”: understanding late colonial community development and its legacy through film', Development and Change, 45:5 (2014), 838-68.

115 Gilbert L. Stephenson was born in 1913, and educated at Haileybury and Pembroke College, Cambridge, where he gained a 3rd in geography and a Boxing Blue. Appointed to the CAS in 1936, he rose to become admin officer, grade I, and retired in 1960. Bird describes him as 'rumbustious': Never the same again, 35.

116 Martin Garner, 'Teaching in Sarawak, 1958-60', in Michael Edwards (ed.), Arriving where we started: 25 years of Voluntary Service Overseas (London: ITDG Publishing, 1983), 9-17, 11; Philip Murphy, Alan Lennox-Boyd: a biography (London: I. B. Tauris, 1999), 242-3.

117 Adams, Voluntary Service Overseas, 81.

118 Swaisland, 'Alec Dickson'.

119 The Daily Express, 29 September 1959, 7.

120 For a summary of VSO selection and training, see Adams, Voluntary Service Overseas, 84-102.

121 Dickson, 'Young man's challenge', 214.

122 'A year in the Commonwealth for young volunteers', The Times, 1 December 1959.

123 'VSO', ISCO Bulletin, 82 (February 1959), 5-7, UCL Institute of Education, DC/ISC/1/19/5, 6.

124 Christopher Tipple, 'Teaching in Ghana, 1959-60', in Edwards, Arriving where we started, 17-23, 18-19; David Waters, Letters from Abetifi (London: Minerva Press, 1999).

125 Gilbert L. Stephenson, 'Nigerian and other days' (unpublished memoir, 1982), the Bodleian Library of Commonwealth and African Studies, Oxford, MSS.Afr.s.1833, 141-2. For a detailed description of the work and life of a volunteer, see Dickson, A world elsewhere, 50-204. These experiences ranged from assisting a local woman give birth on a bus to having to take over as headmaster of a school following the death of the incumbent.

126 Gilbert L. Stephenson, 'To all our volunteers: newsletter no. 6', December 1962, TNA, BW93/24.

127 F. H. Cawson (British Council) to J. R. Bunting (VSO), 21 December 1962, TNA, BW93/24.

128 Alec Dickson, 'The year between', The Sunday Times, 19 April 1959, 10; 'A year in the Commonwealth for young volunteers: British colonies review 4th quarter', The Times, 1 December 1959, 4; 'Confidential reports on volunteers', 1961, TNA, CO/85/1445.

129 'Voluntary Service Overseas', note for the Secretary of State, 14 September 1961, TNA, DO/ $163 / 22$.

130 'A year in the Commonwealth for young volunteers'.

131 Confidential letter A. J. Brown to J. R. Williams, November 1961, TNA, DO/162/22/95.

132 The Malay Mail, 23 November 1961.

133 Wainwright offers a brief general survey of early volunteers' response to VSO and their subsequent trajectories: The volunteers, 131-9.

134 McCleery, 'Cadets' reports 1962/63', CUA, CDEV/3/30.

135 Applicants' references (1961), CUA, CDEV/4/14.

136 Interview summary, 15 December 1961, CUA, CDEV/4/14.

137 Schwarz, The white man's world, 254-7.

138 Sir Alan Burns, 'Call to the colonies', The Times Literary Supplement, 4 May 1962, 306.

139 'Colonial characters', The Guardian, 2 August 1963, 5.

140 See Adams, Voluntary Service Overseas, appendix E: 'VSO's income', 227.

141 Overseas Service Pensioners Association Journal, 80 (October 2000), 11.

\section{Chapter 7}

1 Jean-Pierre Rioux, The Fourth Republic, 1944-1958 (Cambridge: Cambridge University Press, 1987), 85; Tony Chafer, The end of empire in French West Africa: France's successful decolonization? (Oxford: Berg, 2002), 47-50.

2 Chafer, The end of empire in French West Africa, 56-61.

3 Cited in ibid., 57, emphasis original.

4 Martin Shipway, "Transfer of destinies" or business as usual? Republican invented tradition and the problem of "independence" at the end of the French empire', The Round Table, 97:398 (2008), 747-59, 751. 
5 Alexander Keese, Living with ambiguity: integrating an African elite in French and Portuguese Africa, 1930-1961 (Stuttgart: Frank Steiner, 2007); Anna Konieczna, 'La coopération militaire entre la France et l'Afrique du Sud', Revue d'histoire diplomatique, 123:4 (2009), 93-108.

6 '[É]troitement imbriquées les unes dans les autres': 'Mis en lumière l'importance stratégique et économique du Continent tout entier.' Raymond Offroy [head of the Press and Information Service, French Ministry of Foreign Affairs] to French Consul, Accra, 14 June 1946, Centre des Archives Diplomatiques de Nantes [hereafter CADN], 6PO1/11/no.266.

7 Martin Shipway, Decolonization and its impact: a comparative approach to the end of the colonial empires (Malden, MA: Blackwell, 2008); Martin Thomas, Bob Moore and Larry J. Butler, Crises of empire: decolonization and Europe's imperial states, 1918-1975, 2nd edn (London: Bloomsbury, 2015); Martin Thomas, Fight or flight: Britain, France and their roads from empire (Oxford: Oxford University Press, 2014).

8 Joanna Warson, 'Entangled ends of empire: the role of France and francophone Africa in the decolonisation of Rhodesia', Journal of Colonialism and Colonial History, 16:1 (2015).

9 'El Dorado, la Mecque de l'homme qui veut s'enricher rapidement.' R. Clap [administrator in charge of the colonies, Free French Mission, Gold Coast] to commissioner for the colonies, 28 October 1944, CADN/6PO1/5/34.

10 'Un véritable paradis terrestre, où il est possible de gagner de l'argent très vite, où surtout les marchandises affluent ne sont pas chères.' Jean Rouch [temporary member of the French School of Africa; later became a researcher at the Musée de l'Homme] and Roger Rosfelder [member of the Griaule Mission], Rapport sur la tournée effectue en Gold Coast en NovembreDecembre 1950, nd., CADN/6PO1/5.

11 Clap to commissioner for the colonies, 28 October 1944, CADN/6PO1/5/34.

12 Romain Tiquet, 'Migrations protestataires et résistance au travail forcé en AOF, 1900-1946', Hommes et migrations, 1307 (2014), 166-9.

13 'Coupe en deux nombreuses tribus.' Charles Renner [French consul, Accra] to the Governor General of Overseas France, 20 January 1955, CADN/6PO1/5/33.

14 Rouch and Rosfelder, Rapport sur la tournée effectue en Gold Coast.

15 Clap to commissioner for the colonies, 28 October 1944, CADN/6PO1/5/34.

16 Rouch and Rosfelder, Rapport sur la tournée effectue en Gold Coast.

17 Ibid.

18 Press and Information Service, French Ministry of Foreign Affairs, Note de la direction d'AfriqueLevant sur la mission de Monod en Afrique noire, 28 August 1946, CADN/6PO1/11/414.

19 Frederick Cooper, Decolonization and African society: the labor question in French and British Africa (Cambridge: Cambridge University Press, 1996), 41.

20 Ibid., 40.

21 Ibid., 80.

22 Ibid., 88.

23 Ibid., 84, 88.

24 Rouch and Rosfelder, Rapport sur la tournée effectue en Gold Coast, nd., CADN/6PO1/5.

25 Clap to commissioner for the colonies, 28 October 1944, CADN/6PO1/5/34.

26 Jean Rouch, Migrations en Gold Coast, 1954, CADN/6PO1/5.

27 '[L]e plus grand groupement de français résident à l'étranger.' Africa-Levant Department to Personnel, 3 September 1949, Archives du Ministère des Affaires Étrangères [hereafter AMAE], series: Afrique-Levant [hereafter AL], subseries: Possessions Britanniques [hereafter $\mathrm{PB}]$, fo. 149 .

28 '[D]epuis les longues années, les indigènes de nos territoires, à la recherché d'un travail, viennent si volontiers et si nombreux en Gold Coast.' Charles Renner to Governor General, 20 January 1955.

29 Chafer, The end of empire in French West Africa, 48.

30 'Vous savez combien graves sont nos préoccupations quand nous constatons que les populations Mossi continuent d'abandonner leurs pays pour rendre en Gold Coast.' R. Saller [commissioner for the colonies] to Clap, 31 August 1944, CADN/6PO1/5/5967.

31 Jane Burbank and Frederick Cooper, Empires in world history: power and the politics of difference (Princeton, NJ: Princeton University Press, 2010), 420; John Darwin, After Tamerlane: the global history of empire since 1405 (London: Allen Lane, 2007), 464.

32 Shipway, Decolonization and its impact, 13.

33 Chafer, The end of empire in French West Africa, 56-61. 
34 '[E]xcessivement tracassière et peu démocratique.' French consulate, Accra, Rapport de M. Bequey, Vice Consul à Accra sur son voyage à l'occasion du 14 juillet 1948, nd., AMAE/AL/ PB/99-103.

35 Ibid.

36 Ronald Hyam, Britain's declining empire: the road to decolonisation 1918-1968 (Cambridge: Cambridge University Press, 2006), 139-40.

37 Ibid., 140-3, quote at 143.

38 John Hargreaves, Decolonization in Africa, 2nd edn (London: Longman, 1996), 44.

39 Cooper, Decolonization and African society, 177.

40 Renner to Ministry of Foreign Affairs [hereafter MFA], Voyage de Nkrumah en AOF, 10 March 1951, AMAE/AL/PB/42/202-3; Gaston Defferre [minister of Overseas France; hereafter MOF] to MFA, 8 September 1956, AMAE/AL/Gold Coast, 5/822.

41 'La G.C. [Gold Coast] peut être considéré comme le pays de l'Afrique Occidentale le plus évolué dans le domaine politique.' Rouch, Migrations en Gold Coast.

42 '[L] colonie-pilote africaine'. Rouch, Migrations en Gold Coast.

43 Rouch, Migrations en Gold Coast.

44 Ibid.

45 'En résumé, il faut autant que possible, créer chez nous les conditions qui attirant les travailleurs chez les Anglais.' Clap to commissioner for the colonies, 28 October 1944, CADN/6PO1/5/34.

46 '[F]atiguaient profondément nos populations.' Clap to commissioner for the colonies, 28 October 1944.

47 Cited in Cooper, Decolonization and African society, 188.

48 Chafer, The end of empire in French West Africa, 55-79.

49 Keese, Living with ambiguity, 61, 64.

50 Minister of the colonies [hereafter MOC] to MFA, 1 March 1945, AMAE/AL/PB/34/fo.12-13.

51 Guy Monod [embassy secretary, military and administrative transit post, Lagos], 27 March 1946, AMAE/AL/PB/27/fo.6-9.

52 The Free French established missions in Lagos, Accra, Freetown (Sierra Leone) and Bathurst (The Gambia) in 1940, with a central office in Accra. The Freetown and Bathurst branches were closed in 1943, while the Lagos office was turned into a military and administrative transit post. The Accra office was closed on 26 March 1945, with a view to its replacement by a consulate, though this new set-up was not fully established until October 1946. See Belliard [liaison officer, Accra], Note relative à la mission française de Lagos, 24 December 1945, AMAE/AL/PB/27/fo.10-11.

53 Monod, 27 March 1946; Belliard, Note relative à la mission française de Lagos.

54 Monod, 27 March 1946.

55 Ministère des Affaires Étrangères, Annuaire diplomatique et consulaire de la République française (Paris: Imprimerie Nationale, 1921), 46-7.

56 '[I]ndispensable que la France ce soit représentée et bien représentée dans les colonies britanniques de la Côte Occidentale d'Afrique.' Henri Laurentie to Clap, 17 February 1945, AMAE/ $\mathrm{AL} / \mathrm{PB} / 34 /$ fo.10-11.

57 Gsell [consular agent, Accra] to British colonial secretary's office, Accra, 27 March 1946, AMAE/AL/PB/fo.26; French embassy, London, to MFA, 15 May 1946, AMAE/AL/PB/34/ fo.32; MFA to French embassy, London, 17 June 1946, AMAE/AL/PB/34/fo.40.

58 Renner to MFA, 26 July 1950, AMAE/AL/PB/fo.141.

59 Georges Tourot [vice consul, Lagos] to MFA, 4 October 1946, AMAE/AL/PB/27/fo. 43.

60 MOC to MFA, 1 March 1945, AMAE/AL/PB/34/fo.12-13.

61 '[U]ne collaboration plus étroite possible entre les colonies françaises et britanniques de l'Afrique Occidentale.' Balfour to Clap, 4 February 1945, AMAE/AL/PB/34/fo.6; Clap to MOC, 8 February 1945, AMAE/AL/PB/34/fo.5.

62 MOC to MFA, 1 March 1945.

63 '[L]es migrations d'indigènes doivent être étudiées sur place.' Press and Information Service, 28 August 1946, CADN/6PO1/11/414.

64 MFA to MOF, 18 January 1947, AMAE/AL/PB/34/fo.85.

65 '[L]'effort français en Afrique est inconnu'. French consulate, Accra, Rapport de M. Bequey.

66 '[L]es réalisations sociales, économiques et politiques dont bénéficié nos territoires, sur le dévouement et l'œuvre d'un grand nombre de nos médecins, de nos instituteurs, de nos missionnaires, de nos administrateurs.' French consulate, Accra, Rapport de M. Bequey.

67 '[D]onneraient aux panneaux un aspect plus vivant.' French consulate, Accra, Rapport de M. Bequey. 
68 '[D] u rôle et de l'action de l'Assemblé de l'Union Française et des liens qui unissent la métropole et ses territoires d'Outre-Mer.' Tourot to Governor General, AOF, 2 September 1949, AMAE/ $\mathrm{AL} / \mathrm{PB} / 32 /$ fo.215-18.

69 Tourot to MFA, 27 August 1949, AMAE/AL/PB/32/fo.190-4.

70 Anon., 'Challenge to French Africans', Daily Times, 20 June 1949, AMAE/AL/PB/32/ fo.199-200.

71 '[D]e mettre en pratique les principes de notre politique d'Union Française. Non seulement nous avons amorcé le regroupement et assuré la protection de nos ressortissants Africains, mais encore nous avons justifié et prouvé d'une façon concrète l'intérêt que nous portons à leur évolution sociale dans le cadre des devoirs qui découlent de notre présence en Afrique.' Tourot to MFA, 27 August 1949.

72 Anon., 'Challenge to French Africans'.

73 Teissier le Cros [administrator, French vice consulate, Lagos] to MFA, 18 January 1951, AMAE/AL/PB/27/fo.169-76; Anon., 'French doctors on visit to Nigeria', West African Pilot, 7 June 1949, AMAE/AL/PB/32/fo.197; Anon., 'Challenge to French Africans'.

74 '[O]uvrage important et difficile.' '[A]u regroupement de la colonie française en Nigeria.' Morel (MFA) to MOF, 18 January 1951, AMAE/AL/PB/27/fo.154.

75 Renner to MFA, Celebration de la Fête Nationale, 31 August 1948, AMAE/AL/PB/34/ fo.121-4.

76 Anon., 'French National Day observed', African Morning Post, 16 July 1948, AMAE/AL/PB/34/ fo. 125 .

77 'Aucune affaire n'est trop grande ou petite pour qu'on ne vienne lui demander conseil.' Renner to MFA, 26 July 1950.

78 Renner to MFA, 26 July 1950; Teissier le Cros to MFA, 18 January 1951.

79 Teissier le Cros to French general consul, Accra, 21 April 1950, AMAE/AL/PB/27/fo.152-3; Anon., 'Natives of French colonies send off Consul Tourot', Daily Service, 18 April 1950, AMAE/ $\mathrm{AL} / \mathrm{PB} / 27 /$ fo.152-3.

80 '[C]'est principalement sur le plan de la politique coloniale que nos postes auront à s'employer.' Press and Information Service, 28 August 1946, CADN/6PO1/11/414.

81 'Je dois souligner le caractère particulier de mon Consulat situé dans une colonie formant enclave dans les colonies françaises et comptant plusieurs centaines de milliers de ces territoires ayant la citoyenneté française.' Renner to MFA, 26 July 1950.

82 Africa-Levant Department, Note pour la direction du personnel au sujet de M. Tourot, vice-consul à Lagos, 30 December 1946, AMAE/AL/PB/fo.50.

83 Gsell to British colonial secretary's office, Accra, 27 March 1946.

84 Minister of the colonies to superior general commander of the AOF troops, 29 November 1945, AMAE/AL/PB/34/fo.19-20; Laurentie to Clap, 17 February 1945.

85 'L'émigrant africain français, même vivant ici depuis plusieurs années, ne considère pas chez lui.' Renner to the Governor General of Overseas France, 20 January 1955.

86 '[D] ans leurs pays d'origine, c'est-à-dire en territoire français et y gardent des attaches.' Renner to the Governor General of Overseas France, 20 January 1955.

87 Rouch, Migrations en Gold Coast.

88 Renner to the Governor General of Overseas France, 20 January 1955.

89 ' $[I] 1$ serait absurde de considérer les émigrants come des agitateurs prêts à prêcher la croisade de l'independance en Afrique française.' Rouch, Migrations en Gold Coast.

90 '[I]ls n'aiment pas les Noirs.' Rouch, Migrations en Gold Coast.

91 For more on French engagement with anglophone Africa after 1960, see Daniel Bach, 'Dynamique et contradiction dans la politique africaine de la France: les rapports avec le Nigeria (1960-1981)', Politique africaine, 5 (1982), 47-74; Anna Konieczna, 'Les relations des parlementaires française avec l'Afrique du Sud (1960-1974)', Parlement [s]: revue d'histoire politique, 17 (2012), 93-108; and Warson, 'Entangled ends of empire'.

\section{Conclusion}

1 As described in the introduction: see pp. 10-11.

2 Frederick Cooper, Decolonization and African society: the labor question in British and French Africa (Cambridge: Cambridge University Press, 1996), 457. 


\section{Afterword}

1 Leo Tolstoy, War and peace (London: Penguin Books, 2005), vol. III, part II, ch. 39, 910, part III, ch. 1, 911-13. The division of Tolstoy's epic into four volumes and an epilogue, seventeen parts and 361 chapters seems to offer in itself an illustration of the tortoise's segmented progress.

2 Ibid.

3 Ibid., vol. IV, part IV, ch. 11, 1228.

4 Ibid.

5 See Martin Shipway, Decolonisation and its impact: a comparative approach to the end of the colonial empires (Malden, MA: Blackwell, 2008).

6 Benedict Anderson, Imagined communities: reflections on the origin and spread of nationalism, 2nd edn (London: Verso, 2006), 162.

7 Martin Thomas and Andrew Thompson, "Empire and globalisation: from "high imperialism" to decolonisation', International History Review, 36:1 (2014), 1-29, 17, emphasis added.

8 Paul J. Hiniker, Revolutionary ideology and Chinese reality: dissonance under Mao (London: Sage, 1977).

9 Gary Wilder, The French imperial nation-state: negritude and colonial humanism between the two world wars (Chicago, IL: University of Chicago Press, 2005), 78, $77 \mathrm{fn}$.

10 'Our preoccupation with this question of futile intransigence gradually abandoned...': Thomas and Thompson, 'Empire and globalisation', 17.

11 As I have mentioned John Darwin, I should pay tribute also to my subsequent supervisor, the late Vincent Wright, who took me over when John went on a year's sabbatical leave. I could have asked for no more inspiring and authoritative guide to the French official mind.

12 See, for example, Ronald E. Robinson, 'The moral disarmament of African empire, 1919-1947', Journal of Imperial and Commonwealth History, 8:1 (1979), 86-104; and Robert D. Pearce, The turning point in Africa: British colonial policy, 1938-48 (London: Frank Cass, 1982).

13 Wilder, The French imperial nation-state; Gary Wilder, Freedom time: negritude, decolonization and the future of the world (Durham, NC: Duke University Press, 2015).

14 The finding is recorded somewhere in my card index files; given limited and expensive photocopy quotas, in an era well before digital photography, I have no other trace.

15 Martin Shipway, The road to war: France and Vietnam, 1944-1947 (Oxford: Berghahn Books, 1996).

16 See Martin Shipway, 'Thinking like an empire: Governor Henri Laurentie and postwar plans for the late colonial French "empire-state"', in Martin Thomas (ed.), The French colonial mind, vol. I, Mental maps of empire and colonial encounters (Lincoln, NE: University of Nebraska Press, 2011), 219-50, 220.

17 Pierre Messmer, interview with the author and Philippe Oulmont, Paris, 12 March 2007. Messmer was reflecting on his own experience (parachuted into Vietnam in 1945, captured by the Viet Minh, escaped), but he also cited the authority of Laurentie and Paul Mus.

18 Daniel Hémery, 'Un orientaliste dans la décolonisation: les trois audaces de Paul Mus (19391969)', in David Chandler and Christopher E. Goscha (eds.), L'espace d'un regard: l'asie de Paul Mus (1902-1969) (Paris: Les Indes savantes, 2006), 305-16, 308. See also Paul Mus' authoritative 'Note sur la crise morale franco-indochinoise', 1 August 1945, quoted in Chandler and Goscha, L'espace d'un regard, 221-45.

19 John Darwin, 'What was the late colonial state?' Itinerario, 23:3/4 (1999), 73-82.

20 John Darwin, The empire project: the rise and fall of the British world-system 1830-1970 (Cambridge: Cambridge University Press, 2009), 509.

21 Miguel Bandeira Jerónimo and António Costa Pinto, 'A modernizing empire? Politics, culture and economy in Portuguese late colonialism', in Miguel Bandeira Jerónimo and António Costa Pinto (eds.), The ends of European colonial empires: cases and comparisons (Basingstoke: Palgrave Macmillan, 2015), 51-80.

22 ' $[\mathrm{B}]$ oth the way the leaders of empire-states thought and the forms in which political contestation took place reflect "thinking like an empire". [...] Far from being an anachronistic political form in the "modern era", this imperial perspective applies to France, Britain, and other important states of the nineteenth and twentieth centuries.' Frederick Cooper, Colonialism in question: theory, knowledge, history (Berkeley, CA: University of California Press, 2005), 154.

23 Wilder, Freedom time, 4.

24 Darwin, The empire project, xi. 
25 Michael Collins, 'Decolonization and the "federal moment", Diplomacy and Statecraft, 24:1 (2013), 21-40.

26 Michel Foucault, 'Four: 1 February 1978', in Security, territory, population: lectures at the Collège de France, 1977-78, ed. Michel Senellart (Basingstoke: Palgrave Macmillan, 2007), 87-114, 108.

27 Wilder, Freedom time, 43-4.

28 Shipway, Decolonization and its impact, 8.

29 D. A. Low and John Lonsdale, 'Introduction: towards the new order, 1945-1963', in D. A. Low and Alison Smith (eds.), History of East Africa, vol. III (Oxford: Clarendon Press, 1976), 1-63, 13.

30 Martin Shipway, 'The wind of change and the tides of history: de Gaulle, Macmillan and the beginnings of the French decolonising endgame', in Larry J. Butler and Sarah Stockwell (eds.), The wind of change: Harold Macmillan and British decolonisation (Basingstoke: Palgrave Macmillan, 2013), 180-94; Berny Sèbe, 'A fragmented and forgotten decolonisation: the end of European empires in the Sahara and their legacy', in Tony Chafer and Alexander Keese (eds.), Francophone Africa at fifty (Manchester: Manchester University Press, 2013), 204-18.

31 See Stuart Elden, Foucault's last decade (Cambridge: Polity, 2016).

32 Darwin, 'What was the late colonial state?'.

33 Véronique Dimier, Le gouvernement des colonies, regards croisés franco-britanniques (Brussels: Éditions de l'université de Bruxelles, 2004). 


\section{Select bibliography}

Michael Adams, Voluntary Service Overseas: the story of the first ten years (London: Faber, 1969)

Michael Adas, Machines as the measure of men; science, technology, and ideologies of Western Dominance (Ithaca, NY: Cornell University Press, 1989)

Michael Adas, 'A field matures: technology, science, and Western colonialism', Technology and Culture, 38:2 (1997), 478-87

Michael Adas, 'Contested hegemony: the Great War and the Afro-Asian assault on the civilizing mission ideology', Journal of World History, 15:1 (2004), 31-63

Adekeye Adebajo and Kaye Whiteman (eds.), The EU and Africa: from Eurafrique to Afro-Europa (London: Hurst, 2012)

Theodor W. Adorno, Lectures on negative dialectics (Cambridge: Polity, 2008)

Anthony Aldgate and Jeffrey Richards, Best of British: cinema and society from 1930 to the present (London: I. B. Tauris, 1999)

Ambasciata d'Italia and Istituto Italiano di Cultura di Algeri (eds.), Enrico Mattei e l'Algeria: durante la Guerra Liberazione Nazionale (Algiers: Ambasciata d'Italia and Istituto Italiano di Cultura di Algeri, 2010)

Benedict Anderson, Imagined communities: reflections on the origin and spread of nationalism, 2nd edn (London: Verso, 2006)

Carol Anderson, 'International conscience, the Cold War, and apartheid: the NAACP's alliance with the Reverend Michael Scott for South West Africa's liberation, 1946-1951', Journal of World History, 19:3 (2008), 297-325

David Anderson, Histories of the hanged: Britain's dirty war in Kenya and the end of empire: testimonies from the Mau Mau Rebellion in Kenya (London: Weidenfeld \& Nicolson, 2005)

David Anderson, "Mau Mau in the High Court and the "lost" British empire archives: colonial conspiracy or bureaucratic bungle?', Journal of Imperial and Commonwealth History, 39:5 (2011), 699-716

David Anderson, 'Guilty secrets: deceit, denial, and the discovery of Kenya's "migrated archive", History Workshop Journal, 80:1 (2015), 142-60

Arjun Appadurai, Modernity at large: cultural dimensions of globalization (Minneapolis, MN: University of Minnesota Press, 1986)

David E. Apter, Ghana in transition (Princeton, NJ: Princeton University Press, 1963)

Gareth Austin, 'African economic development and colonial legacies', Revue internationale de politique de développement, 1:1 (2010), 11-32

Daniel Bach, 'Dynamique et contradiction dans la politique africaine de la France: les rapports avec le Nigeria (1960-1981)', Politique africaine, 5 (1982), 47-74

Bruna Bagnato, L'Italia e la guerra d'Algeria (1954-1962) (Soveria Mannelli: Rubbettino, 2012)

Jordanna Bailkin, The afterlife of empire (Berkeley, CA: University of California Press, 2012)

Tony Ballantyne and Antoinette Burton, Empires and the reach of the global (Cambridge, MA: Harvard University Press, 2014)

Correlli Barnett, The audit of war: the illusion and reality of Britain as a great nation (London: Macmillan, 1986)

Michael N. Barnett, Empire of humanity: a history of humanitarianism (Ithaca, NY: Cornell University Press, 2011)

Donald Barton, An affair with Africa: Tanganyika remembered (Hertford: AuthorsOnline, 2004)

Christopher A. Bayly, The birth of the modern world, 1780-1914: global connections and comparisons (London: Wiley-Blackwell, 2004) 
Christopher A. Bayly and Tim Harper, Forgotten armies: the fall of British Asia, 1941-45 (London: Allen Lane, 2004)

Christopher A. Bayly and Tim Harper, Forgotten wars: the end of Britain's Asian empire (London: Allen Lane, 2007)

Susan Bayly, 'Conceptualizing resistance and revolution in Vietnam: Paul Mus' understanding of colonialism in crisis', Journal of Vietnamese Studies, 4:1 (2009), 192-205

Charles Becker, Saliou Mbaye and Ibrahima Thioub (eds.), AOF: Réalités et héritages: sociétés Ouest-Africaines et ordre colonial, 1895-1960 (Dakar: Direction des Archives nationales du Sénégal, 1997)

Paul A. Beckett and Crawford Young (eds.), Dilemmas of democratization in Nigeria (Rochester, NY: University of Rochester Press, 1997)

Max Beloff, Imperial sunset: dream of Commonwealth, 1921-42 (London: Macmillan, 1989)

Alain Beltran, A comparative history of national oil companies (Brussels: PIE Peter Lang, 2010)

Brett Bennett and Joseph Morgan Hodge (eds.), Science and empire: knowledge and networks of science in the British empire 1800-1970 (Basingstoke: Palgrave Macmillan, 2011)

Huw Bennett, Fighting the Mau Mau: the British army and counter-insurgency in the Kenya emergency (Cambridge: Cambridge University Press, 2012)

Bruce Berman, Control and crisis in colonial Kenya: the dialectic of domination (Oxford: James Currey, 1990)

Bruce Berman and John Lonsdale, Unhappy valley: conflict in Kenya and Africa (Oxford: James Currey, 1992)

Raymond F. Betts, Assimilation and association in French colonial theory, 1890-1914 (New York, NY: Columbia University Press, 1961)

Pierre Beyssade, La guerre d'Algérie 1954-1962 (Paris: Éditions Planète, 1968)

Jean-Pierre Biondi and Gilles Morin, Les anticolonialistes (1881-1962) (Paris: Hachette, 1992)

Dick Bird, Never the same again: a history of VSO (Cambridge: Lutterworth Press, 1998)

Pascal Blanchard and Sandrine Lemaire (eds.), Culture impériale 1931-1961: les colonies au coeur de la République (Paris: Autrement, 2004)

Louis Blin, L'Algérie, du Sahara au Sahel: route transsaharienne, économie pétrolière et construction de l'état (Paris: L'Harmattan, 1990)

Els Bogaerts and Remco Raben, Beyond empire and nation: the decolonization of African and Asian societies, 1930s-1960s (Leiden: KITLV Press, 2012)

Christophe Bonneuil, 'Development as experiment: science and state-building in late colonial and postcolonial Africa, 1930-1970', Osiris, 15 (2000), 258-81

Philippe Bourdrel, La dernière chance de l'Algérie française: du gouvernement socialiste au retour de de Gaulle, 1956-1958 (Paris: Albin Michel, 1996)

Kenneth Bradley, Diary of a district officer (London: Macmillan, 1942)

Kenneth Bradley, The Colonial Service as a career (London: Stationery Office, 1950)

Kenneth Bradley, A career in the Oversea Civil Service, 2nd edn (London: Stationery Office, 1955)

Daniel Branch, Defeating Mau Mau, creating Kenya: counterinsurgency, civil war and decolonization (Cambridge: Cambridge University Press, 2009)

Piers Brendon, The decline and fall of the British empire, 1781-1997 (London: Jonathan Cape, 2007)

John Breuilly (ed.), The history of nationalism (Oxford: Oxford University Press, 2013)

Georgina Brewis, A social history of student volunteering: Britain and beyond, 1880-1980 (Basingstoke: Palgrave Macmillan, 2014)

Kenneth S. Broun, Saving Nelson Mandela: the Rivonia Trial and the fate of South Africa (Oxford: Oxford University Press, 2012)

Judith M. Brown and William Roger Louis (eds.), The Oxford history of the British empire, vol. IV, The twentieth century (Oxford: Oxford University Press, 1999)

Henri Brunschwig, Mythes et réalités de colonialisme français, 1871-1914 (Paris: Armand Colin, 1960)

Tom Buchanan, “"The truth will set you free”: the making of Amnesty International', Journal of Contemporary History, 37:4 (2002), 575-97

Elizabeth Buettner, Empire families: Britons and late imperial India (Oxford: Oxford University Press, 2004)

Elizabeth Buettner, Europe after empire: decolonization, society and culture (Cambridge: Cambridge University Press, 2016)

Jane Burbank and Frederick Cooper, Empires in world history: power and the politics of difference (Princeton, NJ: Princeton University Press, 2010) 
Michael Burgess, Federalism and the European Union: the building of Europe, 1950-2000 (London: Routledge, 2000)

Roland Burke. "'The compelling dialogue of freedom": human rights at the Bandung Conference', Human Rights Quarterly, 28:4 (2006), 947-65

Roland Burke, 'From individual rights to national development: the first UN International Conference on Human Rights, Tehran, 1968', Journal of World History, 19:3 (2008), 275-96

Roland Burke, Decolonization and the evolution of international human rights (Philadelphia, PN: University of Pennsylvania Press, 2010)

Mathew Burrows, “"Mission civilisatrice”: French cultural policy in the Middle East, 1860-1914', Historical Journal, 29:1 (1986), 109-35

Antoinette Burton, Archive stories: facts, fictions, and the writing of history (Durham, NC: Duke University Press, 2006)

Larry J. Butler and Sarah Stockwell (eds.), The wind of change: Harold Macmillan and British decolonization (Basingstoke: Palgrave Macmillan, 2013)

Jeffrey James Byrne, Mecca of revolution: Algeria, decolonization, and the Third World order (Oxford: Oxford University Press, 2016)

Peter J. Cain, 'Empire and the languages of character and virtue in the later Victorian and Edwardian Britain', Modern Intellectual History, 4:2 (2007), 249-73

Peter J. Cain and Tony Hopkins, British imperialism 1688-2000 (London: Longman, 2002)

Sydney Caine, 'British experiences in overseas development', Annals of the American Academy of Political and Social Science, 270 (1950), 118-25

Helen Callaway, Gender, culture and empire: European women in colonial Nigeria (Chicago, IL: University of Illinois Press, 1987)

Hélder Câmara, Spiral of violence (London: Sheed \& Ward, 1971)

Henry Cattan, The law of oil concessions in the Middle East and North Africa (New York, NY: Parker School of Foreign and Comparative Law, 1981)

John W. Cell, 'On the eve of decolonization: the Colonial Office's plans for the transfer of power in Africa, 1947', Journal of Imperial and Commonwealth History, 8:3 (1980), 235-57

Aimé Césaire, Une saison au Congo (Paris: Seuil, 1966)

Emile Chabal, A divided republic: nation, state and citizenship in contemporary France (Cambridge: Cambridge University Press, 2015)

Tony Chafer, 'French African policy in historical perspective', Journal of Contemporary African Studies, 19:2 (2001), 165-82

Tony Chafer, The end of empire in French West Africa: Fance's successful decolonization? (Oxford: Berg, 2002)

Tony Chafer, 'Education and political socialisation of a national-colonial political elite in French West Africa, 1936-47', Journal of Imperial and Commonwealth History, 35:3 (2007), 437-58

Tony Chafer and Alexander Keese (eds.), Francophone Africa at fifty (Manchester: Manchester University Press, 2013)

David Chandler, 'Paul Mus (1902-1969): a biographical sketch', Journal of Vietnamese Studies, 4:1 (2009), 149-91

David Chandler and Christopher Goscha (eds.), L'espace d'un regard: l'asie de Paul Mus (1902-1969) (Paris: Les Indes savantes, 2006)

Rowena Chapman and Jonathan Rutherford (eds.), Male order: unwrapping masculinity (London: Lawrence \& Wishart, 1987)

Partha Chatterjee, Nationalist thought and the colonial world: a derivative discourse? (London: Zed Books, 1986)

Ann Marie Clark, Diplomacy of conscience: Amnesty International and changing human rights norms (Princeton, NJ: Princeton University Press, 2001)

Peter Clarke and Clive Trebilcock, Understanding decline; perceptions and realities of British economic performance (Cambridge: Cambridge University Press, 1997)

Roger S. Clark, 'The International League for Human Rights and South West Africa 1947-1957: the human rights NGO as catalyst in the international legal process', Human Rights Quarterly, 3:4 (1981), 101-36

Sabine Clarke, 'A technocratic imperial state? The Colonial Office and scientific research, 19401960', Twentieth Century British History, 18:4 (2007), 453-80

Andrew Cohen, 'Development in Africa', African Affairs, 67:266 (1968), 44-54

Andrew Cohen, The politics and economics of decolonization in Africa: the failed experiment of the Central African Federation (London: I. B. Tauris, 2016) 
James S. Coleman, 'Nationalism in tropical Africa', American Political Science Review, 48:2 (1954), 404-26

Lewis John Collins, Faith under fire (London: Frewin, 1966)

Marcus Collins, 'The fall of the English gentleman: the national character in decline, c. 1918-70', Historical Research, 75:187 (2002), 90-111

Michael Collins, Empire, nationalism and the postcolonial world: Rabindranath Tagore's writings on politics, history and society (London: Routledge, 2012).

Michael Collins, 'Decolonization and the "federal moment", Diplomacy and Statecraft, 24:1 (2013), 21-40

Alice L. Conklin, A mission to civilize: the republican idea of empire in France and West Africa, 18951930 (Stanford, CA: Stanford University Press, 1997)

Matthew Connelly, 'Taking off the Cold War lens: visions of North-South conflict during the Algerian War for Independence', American Historical Review, 105:3 (2000), 739-69

Sebastian Conrad, 'Rethinking German colonialism in a global age', Journal of Imperial and Commonwealth History, 41:4 (2013), 543-66

Frederick Cooper, 'The dialectics of decolonization: nationalism and labor movements in post-war Africa', CCST Working Paper, 84 (Ann Arbor, MI: University of Michigan, 1992)

Frederick Cooper, Decolonization and African society: the labor question in French and British Africa (Cambridge: Cambridge University Press, 1996)

Frederick Cooper, Africa since 1940: the past of the present (Cambridge: Cambridge University Press, 2002)

Frederick Cooper, Colonialism in question: theory, knowledge, history (Berkeley, CA: University of California Press, 2005)

Frederick Cooper, 'Possibility and constraint: African independence in historical perspective', Journal of African History, 49:2 (2008), 167-96

Frederick Cooper, 'Reconstructing empire in British and French Africa', Past and Present, 210:6 (2011), 196-210.

Frederick Cooper, Citizenship between empire and nation: remaking France and French Africa, 1945-1960 (Princeton, NJ: Princeton University Press, 2014)

Frederick Cooper and Randall Packard (eds.), International development and the social sciences; essays on the history and politics of knowledge (Berkeley, CA: University of California Press, 1997)

Catherine Coquery-Vidrovitch and Odile Goerg (eds.), L'Afrique Occidentale au temps des français: colonisateurs et colonisés, c. 1860-1960 (Paris: Éditions La Découverte, 1992)

Pierre Cornet, Sahara: terre de demain (Paris: Nouvelles éditions latines, 1956)

Reginald Coupland, East Africa and its invaders: from the earliest times to the death of Seyyid Said in 1856 (Oxford: Clarendon Press, 1938)

Michael Cowen and Robert Shenton, 'The origin and course of Fabian colonialism in Africa', Journal of Historical Sociology, 4:2 (1991), 143-74

Maurice Cranston, What are human rights? (London: Bodley Head, 1973)

Arthur Creech Jones (ed.), New Fabian colonial essays (London: Hogarth Press, 1959)

Gordon Cumming, 'Transporting the "republican" model? A critical appraisal of France's historic mission in Africa', Journal of Contemporary African Studies, 23:2 (2005), 233-53

Lionel Curtis (ed.), The commonwealth of nations: an inquiry into the nature of citizenship in the British empire, and into the mutual relations of the several communities thereof (London: Macmillan, 1916)

Lionel Curtis, Dyarchy (Oxford: Oxford University Press, 1920)

Sarah A. Curtis, Civilizing habits: women missionaries and the revival of French empire (Oxford: Oxford University Press, 2010)

John Darwin, 'What was the late colonial state?', Itinerario, 23:3/4 (1999), 73-82.

John Darwin, After Tamerlane: the global history of empire since 1405 (London: Allen Lane, 2007)

John Darwin, The empire project: the rise and fall of the British world-system 1830-1970 (Cambridge: Cambridge University Press, 2009)

John Darwin, Unfinished empire: the global expansion of Britain (London: Penguin Books, 2012)

James Patrick Daughton, An empire divided: religion, republicanism, and the making of French colonialism (Oxford: Oxford University Press, 2006)

James Patrick Daughton and Owen White, In God's empire: French missionaries in the modern world (Oxford: Oxford University Press, 2011)

Joseph-Roger de Benoist, La balkanisation de l'Afrique Occidentale française (Dakar: Nouvelles éditions africaines, 1979) 
Karl W. Deutsch, Nationalism and social communication: an enquiry into the foundations of nationality (Cambridge, MA: MIT Press, 1953)

Mora Dickson, A world elsewhere: Voluntary Service Overseas (London: Dennis Dobson, 1964)

Mora Dickson (ed.), Alec Dickson: a chance to serve (London: Dennis Dobson, 1976)

Kenneth Onwuka Dike, Trade and politics in the Niger Delta: an introduction to the economic and political history of Nigeria (Oxford: Clarendon Press, 1956)

Véronique Dimier, Le gouvernement des colonies, regards croisés franco-britanniques (Brussels: Éditions de l'université de Bruxelles, 2004)

Véronique Dimier, 'For a new start: resettling French colonial administrators in the Prefectoral Corps', Itinerario, 28:1 (2004), 49-66

Véronique Dimier, 'Three universities and the British elite: a science of colonial administration in the UK', Public Administration, 84:2 (2006), 337-66

Véronique Dimier, The invention of a European development aid bureaucracy: recycling empire (Basingstoke: Palgrave Macmillan, 2014)

Papa Dramé and Samir Saul, 'Le projet d'Eurafrique en France (1946-1960): quête de puissance ou atavisme colonial?', Guerres mondiales et conflits contemporains, 216 (2004), 95-114

Richard Drayton, 'Where does the world historian write from? Objectivity, moral conscience and the past and present of imperialism', Journal of Contemporary History, 46:3 (2011), 671-85

Saul Dubow, 'Macmillan, Verwoerd, and the 1960 "wind of change" speech', Historical Journal, 54:4 (2011), 1087-114

Saul Dubow, South Africa's struggle for human rights (Athens, OH: Ohio University Press, 2012)

Mark Duffield and Vernon Hewitt, Empire, development and colonialism: the past in the present (Woodbridge: James Currey, 2009)

Jost Dülffer and Marc Frey (eds.), Elites and decolonization in the twentieth century (Basingstoke: Palgrave Macmillan, 2011)

Daniel Durand, La politique pétrolière internationale (Paris: Persée, 1970)

Marco Duranti, 'Curbing Labour's totalitarian temptation: European human rights law and British postwar politics', Humanity: An International Journal of Human Rights, Humanitarianism, and Development, 3:3 (2012), 361-83

Jan Eckel and Samuel Moyn (eds.), The breakthrough: human rights in the 1970s (Philadelphia, PA: University of Pennsylvania Press, 2014)

David Edgerton, Warfare state: Britain, 1920-1970 (Cambridge: Cambridge University Press, 2005)

Michael Edwards (ed.), Arriving where we started: 25 years of Voluntary Service Overseas (London: ITDG Publishing, 1983)

Howard Eiland and Michael W. Jennings (eds.), Walter Benjamin: selected writings, vol. IV, 1938-1940 (Cambridge, MA: Harvard University Press, 2003)

Stuart Elden, Foucault's last decade (Cambridge: Polity, 2016)

Caroline Elkins, Imperial reckoning (London: Henry Holt, 2005)

Stephen Ellis, External mission: the ANC in exile, 1960-1990 (London: Hurst, 2012)

Rupert Emerson, 'The fate of human rights in the Third World', World Politics, 27:2 (1975), 201-26

Martin Evans, Algeria: France's undeclared war (Oxford: Oxford University Press 2012)

Ann Ewing, 'The Indian Civil Service 1919-1924: service discontent and the response in London and in Delhi', Modern Asian Studies, 18:1 (1984), 33-53

Elizabeth Ezra, The colonial unconscious: race and culture in interwar France (Ithaca, NY: Cornell University Press, 2000)

Maurice Faivre, Les archives inédites de la politique algérienne, 1958-1962 (Paris: L’Harmattan, 2000)

Toyin Falola, The history of Nigeria (Westport, CT: Greenwood Press, 1999)

Toyin Falola and Emily Brownell (eds.), Africa, empire and globalisation: essays in honour of A. G. Hopkins (Durham, NC: Duke University Press, 2011)

Toyin Falola and Emmanuel M. Mbah (eds.), Contemporary Africa: challenges and opportunities (Basingstoke: Palgrave Macmillan, 2014)

Frantz Fanon, Peau noire, masques blancs (Paris: Seuil, 1952)

Frantz Fanon, A dying colonialism (New York, NY: Grove Press, 1963)

Frantz Fanon, The wretched of the Earth (London: Penguin Books, 1977)

Arlette Farge, The allure of the archives (New Haven, CT: Yale University Press, 2013)

Kent Fedorowich and Martin Thomas (eds.), International diplomacy and colonial retreat (London: Frank Cass, 2001)

James Ferguson, The anti-politics machine (Cambridge: Cambridge University Press, 1990)

Niall Ferguson, Empire: how Britain made the modern world (London: Penguin Books, 2003) 
H. John Field, Toward a programme of imperial life: the British empire at the turn of the twentieth century (Oxford: Clio Press, 1982)

David K. Fieldhouse, 'Can Humpty-Dumpty be put together again? Imperial history in the 1980s', Journal of Imperial and Commonwealth History, 12:2 (1984), 9-23

David K. Fieldhouse, The West and the Third World: trade, colonialism, dependence and development (Oxford: Blackwell, 1999)

Ruth First, 117 Days (London: Penguin Books, 1965)

Edward P. Fitzgerald, 'Did France's colonial empire make economic sense? A perspective from the postwar decade, 1946-1956', Journal of Economic History, 48:2 (1988), 373-85

John Flint, 'Planned decolonization and its failure in British Africa', African Affairs, 82:328 (1983), $389-411$

Pierre Fontaine, Bataille pour le pétrole française (Paris: Je Sers, 1956)

Michel Foucault, Security, territory, population: lectures at the Collège de France, 1977-78, ed. Michel Senellart (Basingstoke: Palgrave Macmillan, 2007)

Martin Francis, 'Tears, tantrums, and bared teeth: the emotional economy of three Conservative prime ministers, 1951-1963', Journal of British Studies, 41:3 (2002), 354-87

Martin Francis, 'A flight from commitment? Domesticity, adventure and the masculine imaginary in Britain after the Second World War', Gender and History, 19:1 (2007), 163-85

Paul Frankel, Mattei: oil and power politics (London: Faber, 1968)

Bill Freund, The African city: a history (Cambridge: Cambridge University Press, 2007)

Frank Furedi, 'Creating a breathing space: the political management of colonial emergencies', Journal of Imperial and Commonwealth History, 21:3 (1993), 89-106

Sir Ralph Furse, Aucuparius: recollections of a recruiting officer (Oxford: Oxford University Press, 1962)

Lewis H. Gann and Peter Duignan (eds.), African proconsuls: European governors in Africa (New York, NY: Free Press, 1978)

Giuliano Garavini, After empires: European integration, decolonization, and the challenge from the global South (Oxford: Oxford University Press, 2012)

Leigh A. Gardner, Taxing colonial Africa: the political economy of British imperialism (Oxford: Oxford University Press, 2012)

W. Rick Garside, British unemployment 1919-1939: a study in public policy (Cambridge: Cambridge University Press, 2002)

Ernest Gellner, Nations and nationalism (Oxford: Blackwell, 1983)

Prosser Gifford and William Roger Louis (eds.), The transfer of power in Africa: decolonization, 1940-1960 (New Haven, CT: Yale University Press, 1982)

Prosser Gifford and William Roger Louis (eds.), Decolonization and African independence: the transfers of power, 1960-1980 (New Haven, CT: Yale University Press, 1988)

Helen Gilbert and Chris Tiffin, Burden or benefit? Imperial benevolence and its legacies (Bloomington, IN: Indiana University Press, 2008)

Robert Gildea, Fighters in the shadows (London: Faber \& Faber, 2015)

Raoul Girardet, L'idée colonial en France (Paris: Hachette, 2005)

Julian Go, Patterns of empire: the British and American empires, 1688 to the present (Cambridge: Cambridge University Press, 2011)

Michael Goebel, Anti-imperial metropolis: interwar Paris and the seeds of Third World nationalism (Cambridge: Cambridge University Press, 2015)

David Goldsworthy, Colonial issues in British politics 1945-61: from 'colonial development' to 'wind of change' (Oxford: Clarendon Press, 1971)

Godfrey Golzen and Margaret Stewart, Working abroad: the Daily Telegraph guide to working and living overseas (London: K. Page, 1977)

Christopher E. Goscha, Vietnam: un état né dans la guerre 1945-1954 (Paris: Armand Collins, 2011)

Christopher E. Goscha, “'So what did you learn from war?” Violent decolonization and Paul Mus's search for humanity', South East Asia Research, 20:4 (2012), 569-93

Richard Gott, Britain's empire: resistance, repression and revolt (London: Verso, 2011)

Leslie E. Grayson, National oil companies (Chichester: Wiley, 1981)

Lee Grieveson and Colin MacCabe, Film and the end of empire (Basingstoke: Palgrave Macmillan, 2011)

Henri Grimal, Decolonization: the British, French, Dutch and Belgian empires, 1919-1963 (London: Routledge, 1978)

Benjamin Grob-Fitzgibbon, Imperial endgame: Britain's dirty wars and the end of empire (Basingstoke: Palgrave Macmillan, 2011) 
Catherine Hall and Sonya Rose (eds.), At home with the empire: metropolitan culture and the imperial world (Cambridge: Cambridge University Press, 2006)

Lord Hailey, 'Nationalism in Africa', Journal of the Royal African Society, 36:143 (1937), 134-47

William Keith Hancock, Survey of Commonwealth affairs, 2 vols. (Oxford: Oxford University Press, 1942)

William Keith Hancock, Argument of empire (London: Penguin Books, 1943)

Peo Hansen and Stefan Jonsson, Eurafrica: the untold history of European integration and colonialism (London: Bloomsbury, 2014)

Michael Hardt and Antonio Negri, Empire (Cambridge, MA: Harvard University Press, 2000)

John Hargreaves, Decolonization in Africa, 2nd edn (London: Longman, 1996)

J. Ernest Hartshorn, Oil companies and governments: an account of the international oil industry and its political environment (New York, NY: Perseus, 1969)

Michael Havinden and David Meredith, Colonialism and development: Britain and its tropical colonies, 1950-1960 (Abingdon: Routledge, 1996)

Matthew M. Heaton, Black skin, white coats: Nigerian psychiatrists, decolonization, and the globalization of psychiatry (Athens, OH: Ohio University Press, 2013)

Frank Heinlein, British government policy and decolonisation, 1945-1963: scrutinising the official mind (London: Frank Cass, 2002)

Denis Herbstein, White lies: Canon John Collins and the secret war against apartheid (Oxford: James Currey, 2004)

Robert Heussler, Yesterday's rulers: the making of the British Colonial Service (Syracuse, NY: Syracuse University Press, 1963)

Matthew Hilton, 'Ken Loach and the Save the Children film: humanitarianism, imperialism, and the changing role of charity in postwar Britain', Journal of Modern History, 87:2 (2015), 357-94

Matthew Hilton, James McKay, Nicholas Crowson and Jean-François Mouhot, The politics of expertise: how NGOs shaped modern Britain (Oxford: Oxford University Press, 2013)

Rita Hinden, 'Economic plans and problems in the British colonies', World Affairs, 112:3 (1949), 77-9

Paul J. Hiniker, Revolutionary ideology and Chinese reality: dissonance under Mao (London: Sage, 1977)

Paul Hirst and Grahame Thompson, Globalization in question (Cambridge: Polity, 1996)

Joseph Morgan Hodge, Triumph of the expert: agrarian doctrines of development and the legacies of British colonialism (Athens, OH: Ohio University Press, 2007)

Joseph Morgan Hodge, 'British colonial expertise, postcolonial careering and the early history of international development,' Journal of Modern European History, 8:1 (2010), 24-46

Joseph Morgan Hodge, 'Writing the history of development (part 2: longer, deeper, wider)', Humanity: An International Journal of Human Rights, Humanitarianism, and Development, 7:1 (2016), 125-74, 138-42

Thomas Hodgkin, Nationalism in colonial Africa (London: Frederick Muller, 1956)

Stanley Hoffman, 'Mus (Paul) - "Le destin de l'Union française: de l'Indochine à l'Afrique": revue', Revue économique, 7:3 (1956), 503-4

Robert F. Holland (ed.), Emergencies and disorder in the European empires after 1945 (London: Frank Cass, 1994)

Tony Hopkins, 'Rethinking decolonization', Past and Present, 200 (2008), 211-47

Stephen Howe, Anti-colonialism in British politics: the left and the end of empire (Oxford: Clarendon Press, 1993)

Stephen Howe, 'David Fieldhouse and "imperialism": some historiographical revisions', Journal of Imperial and Commonwealth History, 26:2 (1998), 213-32

Elise Huillery, 'History matters: the long-term impact of colonial public investments in French West Africa', American Economic Journal: Applied Economics, 1:2 (2009), 176-219

Elise Huillery, 'The black man's burden: the cost of colonization of French West Africa' Journal of Economic History, 74:1 (2014), 1-38

Lynn Hunt, Inventing human rights: a history (New York, NY: W. W. Norton, 2007)

Lynn Hunt, Measuring time, making history (Budapest: Central European University Press, 2008)

Emma Hunter, 'Dutiful subjects, patriotic citizens and the concept of good citizenship in twentiethcentury Tanzania,' Historical Journal, 56:1 (2013), 257-77

Emma Hunter, Political thought and the public sphere in Tanzania: freedom, democracy and citizenship in the era of decolonization (Cambridge: Cambridge University Press, 2015)

Ronald Hyam, 'The political consequences of Seretse Khama', Historical Journal, 29:4 (1986), 921-47 
Ronald Hyam, 'The geopolitical origins of the Central African Federation: Britain, Rhodesia and South Africa, 1948-1953', Historical Journal, 30:1 (1987), 145-72

Ronald Hyam, Britain's declining empire: the road to decolonisation 1918-1968 (Cambridge: Cambridge University Press, 2006)

Ronald Hyam and William Roger Louis (eds.), British documents on the end of empire, vol. IV, The Conservative government and the end of empire 1957-1964 (London: Stationery Office, 2000)

Ryo Ikeda, The imperialism of French decolonisation: French policy and the Anglo-American response in Tunisia and Morocco (Basingstoke: Palgrave Macmillan, 2015)

John Iliffe, Africans: the history of a continent, 2nd edn (Cambridge: Cambridge University Press, 2007)

Ryan M. Irwin, 'Apartheid on trial: South West Africa and the International Court of Justice, 196066', International History Review, 32:4 (2010), 619-42

Ryan M. Irwin, 'Imagining nation, state, and order in the mid-twentieth century', Kronos, 37:1 (2011), 12-22

Ryan M. Irwin, Gordian knot: apartheid and the unmaking of the liberal world order (Oxford: Oxford University Press, 2012)

Karl Ittmann, A problem of great importance: population, race, and power in the British empire, 19181973 (Berkeley, CA: University of California Press, 2013)

Ashley Jackson, 'Empire and beyond: the pursuit of overseas national interests in the late twentieth century', English Historical Review, 123:499 (2007), 1350-66

Robert H. Jackson, Quasi-states: sovereignty, international relations, and the Third World (Cambridge: Cambridge University Press, 1990)

Leslie James, George Padmore and decolonization from below: pan-Africanism, the Cold War, and the end of empire (Basingstoke: Palgrave Macmillan, 2015)

Leslie James and Elisabeth Leake (eds.), Decolonization and the Cold War: negotiating independence (London: Bloomsbury, 2015)

Simon James, British government: a reader in policy making (London: Routledge, 1997)

Lisa Jardine, Temptation in the archives: essays in golden age Dutch culture (London: UCL Press, 2015)

Michael Jennings, Surrogates of the state: NGOs, development, and Ujamaa in Tanzania (West Hartford, CT: Kumarian Press, 2008)

Chris Jeppesen, "'Sanders of the River, still the best job for a British boy": recruitment to the Colonial Administrative Service at the end of empire', Historical Journal, 59:2 (2016), 469-508

Miguel Bandeira Jerónimo and António Costa Pinto (eds.), The ends of European colonial empires: cases and comparisons (Basingstoke: Palgrave Macmillan, 2015)

Nerys John, 'The campaign against British bank involvement in apartheid South Africa', African Affairs, 99:396 (2000), 415-33

Max Jones, "National hero and very queer fish": empire, sexuality and the British remembrance of General Gordon, 1918-72', Twentieth Century British History, 26:2 (2015), 175-202

Sir Apolo Kagwa, The Kings of Buganda (London: Macmillan, 1901)

Miles Kahler, Decolonization in Britain and France: the domestic consequences of international relations (Princeton, NJ: Princeton University Press, 1984)

Artemy M. Kalinovsky and Craig Daigle (eds.), The Routledge handbook of the Cold War (London: Routledge, 2014)

Hent Kalmo and Quentin Skinner, Sovereignty in fragments: the past, present and future of a contested concept (Cambridge: Cambridge University Press, 2010)

Ethan B. Kapstein, The insecure alliance: energy crises and Western politics since 1944 (Oxford: Oxford University Press, 1990)

Elie Kedourie, Nationalism (London: Hutchinson, 1960)

Elie Kedourie (ed.), Nationalism in Asia and Africa (London: Routledge, 1974)

Alexander Keese "'Quelques satisfactions d'amour-propre": African elite integration, the Loi-cadre, and involuntary decolonization of French Tropical Africa,' Itinerario, 26:1 (2003), 33-57

Alexander Keese, Living with ambiguity: integrating an African elite in French and Portuguese Africa, 1930-61 (Stuttgart: Franz Steiner, 2007)

Paul Kelemen, 'Modernising colonialism: the British Labour movement and Africa', Journal of Imperial and Commonwealth History, 34:2 (2006), 223-44

Dane Kennedy, 'The imperial history wars', Journal of British Studies, 54:1 (2015), 5-22

John Kent, The internationalization of colonialism: Britain, France, and black Africa 1939-1956 (Oxford: Oxford University Press, 1992) 
David Killingray, Fighting for Britain: African soldiers in the Second World War (Woodbridge: James Currey, 2010)

Anthony Kirk-Greene, A biographical dictionary of the Colonial Service, 1936-1966 (London: H. Zell, 1991)

Anthony Kirk-Greene, 'Decolonisation in British Africa', History Today, $42: 1$ (1992), www.historytoday.com/anthony-greene/decolonisation-british-africa

Anthony Kirk-Greene, On Crown service: a history of HM Colonial and Overseas Civil Service, 18371997 (London: I. B. Tauris, 1999)

Anthony Kirk-Greene, Britain's imperial administrators, 1858-1966 (Basingstoke: Macmillan, 2000)

Anthony Kirk-Greene, Symbol of authority: the British district officer in Africa (London: I. B. Tauris, 2006)

Fabian Klose, 'The colonial testing ground: the International Committee of the Red Cross and the violent end of empire', Humanity: An International Journal of Human Rights, Humanitarianism, and Development, 2:1 (2011), 107-26

Fabian Klose, Human rights in the shadow of colonial violence: the wars of independence in Kenya and Algeria (Philadelphia, PA: University of Pennsylvania Press, 2013)

Robert J. Knecht, Renaissance warrior and patron: the reign of Francis I (Cambridge: Cambridge University Press, 1994)

Anna Konieczna, 'La coopération militaire entre la France et l'Afrique du Sud', Revue d'histoire diplomatique, 123:4 (2009), 93-108

Anna Konieczna, 'Les relations des parlementaires française avec l'Afrique du Sud (1960-1974)', Parlement [s]: revue d'histoire politique, 17 (2012), 93-108

Reinhart Koselleck, Futures past: on the semantics of historical time (New York, NY: Columbia University Press, 2004)

Reinhart Koselleck and Melvin Richter, 'Crisis', Journal of the History of Ideas, 67:2 (2006), $357-400$

Sandrine Kott, 'Une “communauté épistémique” du social?', Genèses, 71: 2 (2008), 26-46

Yaël Kouzmine, Le Sahara algérien: intégration national et développement régional (Paris: L'Harmattan, 2012)

Seth Koven, The match girl and the heiress (Princeton, NJ: Princeton University Press, 2015)

Norma J. Kriger, Zimbabwe's guerrilla war: peasant voices (Cambridge: Cambridge University Press, 1992)

Milan Kundera, The book of laughter and forgetting (London: Penguin Books, 1983)

Kwasi Kwarteng, Ghosts of empire: Britain's legacies in the modern world (London: Bloomsbury, 2012)

David Lambert and Alan Lester (eds.), Colonial lives across the British empire: imperial careering in the long nineteenth century (Cambridge: Cambridge University Press, 2006)

David Lan, Guns and rain: guerrillas and spirit mediums in Zimbabwe (London: James Currey, 1985)

Agathe Larcher-Goscha, 'Ambushed by history: Paul Mus and colonial France's "forced re-entry" into Vietnam (1945-1954)', Journal of Vietnamese Studies, 4:1 (2009), 206-39

Paul Gordon Lauren, The evolution of international human rights: visions seen (Philadelphia, PA: University of Pennsylvania Press, 2003)

Benjamin N. Lawrance, Emily Lynn Osborn and Richard L. Roberts (eds.), Intermediaries, interpreters, and clerks: African employees in the making of colonial Africa (Madison, WI: University of Wisconsin Press, 2006)

Herman Lebovics, True France: the wars over cultural identity, 1900-1945 (Ithaca, NY: Cornell University Press, 1992)

Herman Lebovics, Bringing the empire back home: France in the global age (Durham, NC: Duke University Press, 2004)

Christopher J. Lee (ed.), Making a world after empire: the Bandung moment and its political afterlives (Athens, OH: Ohio University Press, 2010)

Lisa Moses Leff, 'Jews, liberals and the civilizing mission in nineteenth-century France', Historical Reflections/Réflexions historiques, 32:1 (2006), 105-28

Melvyn P. Leffler and Odd Arne Westad (eds.), The Cambridge history of the Cold War, vol. I, Origins, 1945-1962 (Cambridge: Cambridge University Press, 2010)

Adam Lent, British social movements since 1945: sex, colour, peace and power (Basingstoke: Palgrave Macmillan, 2001)

Alan Lester, 'Imperial history by the book: a roundtable on John Darwin's The Empire Project. Comment: geo-strategy (and violence) in the making of the modern world', Journal of British Studies, 54:4 (2015), 977-83

Philippa Levine, The British empire: sunrise to sunset (London: Longman, 2007) 
Joanna Lewis, "Tropical East Ends" and the Second World War: some contradictions in Colonial Office welfare initiatives,' Journal of Imperial and Commonwealth History, 28:2 (2000), 42-66

Joanna Lewis, Empire state-building: war and welfare in Kenya 1925-52 (Oxford: James Currey, 2001)

Colin Leys, Underdevelopment in Kenya: the political economy of neo-colonialism (London: Heinemann, 1975)

Tania Murray Li, The will to improve: governmentality, development, and the practice of politics (Durham, NC: Duke University Press, 2007)

Erik Linstrum, Ruling minds: psychology in the British empire (Cambridge, MA: Harvard University Press, 2016)

John Lonsdale, 'The emergence of African nations: a historiographical analysis', African Affairs, 67:266 (1968), 11-28

John Lonsdale, 'Some origins of nationalism in East Africa', Journal of African History, 9:1 (1968), 119-46

Patricia Lorcin, Imperial identities: stereotyping, prejudice, and race in colonial Algeria (London: I. B. Tauris, 1995)

William Roger Louis (ed.), Yet more adventures with Britannia: personalities, politics and culture in Britain (London: I. B. Tauris, 2005)

William Roger Louis and Ronald E. Robinson, 'The imperialism of decolonization', Journal of Imperial and Commonwealth History, 22:3 (1994), 462-511

D. A. Low and Alison Smith (eds.), History of East Africa, vol. III (Oxford: Clarendon Press, 1976)

Jean Loyrette, Le code pétrolier saharien (Paris: Librairie générale de droit et de jurisprudence, 1961)

Martin Lynn (ed.), The British empire in the 1950s: retreat or revival? (Basingstoke: Palgrave Macmillan, 2006)

John MacKenzie (ed.), Imperialism and popular culture (Manchester: Manchester University Press, 1986)

John MacKenzie, 'The British empire: ramshackle or rampaging? A historiographical reflection', Journal of Imperial and Commonwealth History, 43:1 (2015), 99-124

John MacKenzie (ed.), The encyclopedia of empire, 4 vols. (Chichester: Wiley, 2016)

Halford John Mackinder, 'The geographical pivot of history', Geographical Journal, 23:4 (1904), 421-37

Robert J. McMahon (ed.), The Cold War in the Third World (Oxford: Oxford University Press, 2013)

Harold Macmillan, Pointing the way, 1959-61 (London: Macmillan, 1972)

Norrie MacQueen, The decolonization of Portuguese Africa: metropolitan revolution and the dissolution of empire (London: Longman, 1997)

Ichiro Maekawa, 'Neo-colonialism reconsidered: a case study of East Africa in the 1960s and 1970s', Journal of Imperial and Commonwealth History, 43:2 (2015), 317-41

Redha Malek, L’Algérie à Évian: histoire des négociations secrètes, 1956-1962 (Paris: Seuil, 1995)

Mahmood Mamdani, Citizen and subject: contemporary Africa and the legacy of late colonialism (Princeton, NJ: Princeton University Press, 1996)

Peter Mandler, The English national character: the history of an idea from Edmund Burke to Tony Blair (New Haven, CT: Yale University Press, 2006)

Erez Manela, The Wilsonian moment: self-determination and the international origins of anticolonial nationalism (Oxford: Oxford University Press, 2007)

James A. Mangan, The games ethic and imperialism: aspects of the diffusion of an ideal (Harmondsworth: Viking, 1986)

Gregory Mann, Native sons: West African veterans and France in the twentieth century (Durham, NC: Duke University Press, 2006)

Gregory Mann, From empires to NGOs in the West African Sahel: the road to nongovernmentality (Cambridge: Cambridge University Press, 2014)

Nicholas Mansergh, The Commonwealth experience: from British to multiracial Commonwealth (London: Weidenfeld \& Nicholson, 1969)

Jacques Marseille, 'La gauche, la droite et la fait colonial en France: des années 1880 aux années 1960', Vingtième siècle: révue d'histoire, 24:1 (1989), 17-28

Marc Matera, Black London: the imperial metropolis and decolonization in the twentieth century (Berkeley, CA: University of California Press, 2015)

Anthony S. Matthews and Ronald C. Albino, 'Permanence of the temporary: an examination of the 90- and 180-day Detention Laws', South African Law Journal, 83:1 (1966), 16-43

Leonardo Maugeri, L'era del petrolio: mitologia, storia e future della più controversa risorsa del mondo (Milan: Feltrinelli, 2006) 
Daniel Maul, Human rights, development and decolonization: the International Labour Organization, 1940-70 (Basingstoke: Palgrave Macmillan, 2012)

Mark Mazower, No enchanted palace: the end of empire and the ideological origins of the United Nations (Princeton, NJ: Princeton University Press, 2009)

Alamin M. Mazrui and Willy Mutunga (eds.), Governance and leadership: debating the African condition (Trenton, NJ: Africa World Press, 2003)

Achille Mbembe, On the postcolony (Berkeley, CA: University of California Press, 2001)

Elikia M'Bokolo, 'Forces sociales et idéologies dans la décolonisation de l'A.E.F.', Journal of African History, 22:3 (1981), 393-407

Allan Megill, 'Recounting the past: “description”, explanation, and narrative in historiography', American Historical Review, 94:3 (1989), 627-53

James Midgley and David Piachaud, Colonialism and welfare: social policy and the British imperial legacy (Cheltenham: Edward Elgar, 2011)

Josephine Fishel Milburn, 'The Fabian Society and the British Labour Party', Western Political Quarterly, 11:2 (1958), 319-39

Farina Mir (ed.), 'AHR roundtable: the archives of decolonization', American Historical Review, 120:3 (2015), 844-950

Maria Misra, 'Colonial officers and gentlemen: the British empire and the globalization of "tradition"', Journal of Global History, 3:2 (2008), 135-61

Wolfgang J. Mommsen and Jürgen Osterhammel (eds.), Imperialism and after: continuities and discontinuities (London: Allen \& Unwin, 1986)

Kenneth O. Morgan, 'Imperialism at bay: British Labour and decolonization', Journal of Imperial and Commonwealth History, 27:2 (1999), 233-54

Frank Mort, Capital affairs: London and the making of the permissive society (New Haven, CT: Yale University Press, 2010)

Samuel Moyn, The last utopia: human rights in history (Cambridge, MA: Belknap Press of Harvard University Press, 2010)

Samuel Moyn, 'Fantasies of federalism', Dissent, 62:1 (2015), 145-51

Phillip Murphy, Party politics and decolonization: the Conservative Party and British colonial policy in tropical Africa, 1951-1964 (Oxford: Clarendon Press, 1995)

Philip Murphy, Alan Lennox-Boyd: a biography (London: I. B. Tauris, 1999)

Paul Mus, Le destin de l'Union française (Paris: Seuil, 1954)

Paul Mus, Guerre sans visage: lettres commentées du sous-lieutenant Émile Mus (Paris: Seuil, 1961)

Dadabhai Naoroji, Poverty and un-British rule in India (London: Swan Sonnenschein, 1901)

Gamal Abdel Nasser, The philosophy of the revolution (Cairo: S.O.P. Press, 1952)

Ed Naylor (ed.), France's modernising mission: welfare, citizenship, and the ends of empire (Basingstoke: Palgrave Macmillan, 2017)

Bhebe Ngwabi and Terence Ranger (eds.), Society in Zimbabwe's liberation war (Oxford: James Currey, 1996)

Ingrid Nifosi, The UN special procedures in the field of human rights (Holmes Beach, FL: Gaunt, 2005)

Kwame Nkrumah, Neo-colonialism: the last stage of imperialism (London: Thomas Nelson \& Sons, 1965)

Paul Nugent, Africa since independence (Basingstoke: Palgrave Macmillan, 2012)

Roland Oliver, The missionary factor in East Africa (London: Longmans, 1952)

Roland Oliver, Sir Harry Johnston and the scramble for Africa (London: Chatto \& Windus, 1957)

Roland Oliver and John D. Fage, A short history of Africa (London: Penguin Books, 1962)

Roland Oliver and Gervase Mathew (eds.) History of East Africa, vol. I (Oxford: Clarendon Press, 1963)

Melanie Oppenheimer and Nicholas Deakin (eds.), Beveridge and voluntary action in Britain and the wider British world (Manchester: Manchester University Press, 2011)

Roger Owen and Bob Sutcliffe (eds.), Studies in the theory of imperialism (London: Longmans, 1972)

Ben Page, "'And the Oscar goes to... Daybreak in Udi": understanding late colonial community development and its legacy through film', Development and Change, $45: 5$ (2014), 838-68

Ali Parchami, Hegemonic peace and empire: the Pax Romana, Britannica, and Americana (London: Routledge, 2009)

Charles Parkinson, Bills of rights and decolonization: the emergence of domestic human rights instruments in Britain's Overseas Territories (Oxford: Oxford University Press, 2007)

Jeremy Paxman, Empire: what ruling the world did to the British (London: Viking, 2012)

Robert Pearce, The turning point in Africa: British colonial policy, 1938-48 (London: Frank Cass, 1982) 
Susan Pedersen, The guardians: the League of Nations and the crisis of empire (Oxford: Oxford University Press, 2015)

Edith Penrose, The large international firm in developing countries: the international petroleum industry (London: Allen \& Unwin, 1968)

Georges Perec, Species of spaces and other pieces (London: Penguin Books, 1999)

Mario Pirani, Poteva andare peggio: mezzo secolo di ragionevoli illusioni (Milan: Mondadori, 2012)

Andrew N. Porter and Anthony J. Stockwell (eds.), British imperial policy and decolonization 1938-64, vol. I, 1938-51 (Basingstoke: Palgrave Macmillan, 1987)

Bernard Porter, The absent-minded imperialists: empire, society, and culture in Britain (Oxford: Oxford University Press, 2004)

Bernard Porter, Critics of empire: British radicals and the imperial challenge, 2nd edn (London: I. B. Tauris, 2008)

Bernard Porter, British imperial: what the empire wasn't (London: I. B. Tauris, 2016)

Simon Potter and Jonathan Saha, 'Global history, imperial history and connected histories of empire,' Journal of Colonialism and Colonial History, 16:1 (2015), www.muse.jhu.edu/article/ 577738

Sir Hilton Poynton, Africa in the colonial period: the colonial administrator in the age of decolonization (Oxford: Committee for African Studies, 1978)

Daniele Pozzi, Dai gatti selvaggi al cane a sei zampe (1926-1967) (Venice: Marsilio, 2009)

Richard Price, 'One big thing: Britain, its empire, and their imperial culture', Journal of British Studies, 45:3 (2006), 602-27

Christopher Prior, Exporting empire: Africa, colonial officials and the construction of the imperial state c. 1900-39 (Manchester: Manchester University Press, 2013)

Christopher Prior, 'A brotherhood of Britons? Public schooling, esprit de corps and colonial officials in Africa, c.1900-1939', History, 98:330 (2013), 174-90

Patricia Pugh, Educate, agitate, organise: 100 years of Fabian socialism (London: Methuen, 1984)

Kate Quinn (ed.), Black power in the Caribbean (Gainsville, FL: University Press of Florida, 2014)

Terence Ranger, Emerging themes of African historiography (Nairobi: East African Publishing House, 1968)

Terence Ranger, Peasant consciousness and guerrilla war in Zimbabwe (London: James Currey, 1985)

Glenn Richardson, Renaissance monarchy: the reigns of Henry VIII, Francis I and Charles V (London: Arnold, 2002)

Charlotte Lydia Riley, “"Tropical allsorts”: the transnational flavour of British development policies in Africa', Journal of World History, 26:4 (2015), 839-64

Jean-Pierre Rioux, The Fourth Republic, 1944-1958 (Cambridge: Cambridge University Press, 1987)

Jean-Pierre Rioux (ed.), La guerre d'Algérie et les Français (Paris: Fayard, 1990)

Helen Roberts, 'Witness: the origins of justice', Paragon Review (1998), www.hull.ac.uk/oldlib/ archives/paragon/1997/witness.html

Amanda Lea Robinson, 'National versus ethnic identification in Africa: modernization, colonial legacy, and the origins of territorial nationalism', World Politics, 66:4 (2014), 709-46

Ronald E. Robinson, 'The moral disarmament of African empire, 1919-1947', Journal of Imperial and Commonwealth History, 8:1 (1979), 86-104

John Holland Rose, Arthur Percival Newton and Ernest Alfred Benians (eds.), The Cambridge history of the British empire, vol. I, The old empire from the beginnings to 1783 (New York, NY: Macmillan, 1929)

Jonathan Rose, The intellectual life of the British working classes, 2nd edn (New Haven, CT: Yale University Press, 2010)

Clifford Rosenberg, 'Albert Sarraut and republican radical thought', French Politics, Culture and Society, 20:3 (2002), 97-114

Kristin Ross, May '68 and its afterlives (Chicago, IL: University of Chicago Press, 2002)

Robert I. Rotberg, 'African nationalism: concept or confusion?' Journal of Modern African Studies, 4:1 (1966), 33-46

Robert I. Rotberg (ed.), When states fail: causes and consequences (Princeton, NJ: Princeton University Press, 2004)

Peggy R. Sabatier, “"Elite” education in French West Africa: the era of limits, 1903-1945', International Journal of African Historical Studies, 11:2 (1978), 247-66

Emmanuel Saint-Martin and Romain Gubert, L'Arrogance française (Paris: Jacob Duvernet, 2003)

Anthony Sampson, Anatomy of Britain (London: Hodder \& Stoughton, 1962)

Oscar Sanchez-Sibony, Red globalization: the political economy of the Soviet Cold War from Stalin to Khrushchev (Cambridge: Cambridge University Press, 2014) 
Christopher Saunders, 'Michael Scott and Namibia', African Historical Review, 39:2 (2007), 25-40

Mike Savage, 'Affluence and social change in the making of technocratic middle-class identities: Britain, 1939-55', Contemporary British History, 22:4 (2008), 457-76

Mike Savage and Andy Miles, 'The strange survival story of the English gentleman, 1945-2010', Cultural and Social History, 9:4 (2012), 595-612

Catherine Schenk, The decline of sterling: managing the retreat of an international currency 1945-1992 (Cambridge: Cambridge University Press, 2010)

Arthur Schlesinger, A thousand days: John F. Kennedy in the White House (Boston, MA: Houghton Mifflin, 1965)

Elizabeth Schmidt, 'Top down or bottom up? Nationalist mobilization reconsidered, with special reference to Guinea (French West Africa)', American Historical Review, 110:4 (2005), 975-1014

Elizabeth Schmidt, Cold War and decolonization in Guinea, 1946-1958 (Athens, OH: Ohio University Press, 2007)

Camilla Schofield, Enoch Powell and the making of postcolonial Britain (Cambridge: Cambridge University Press, 2013)

Rohland Schuknecht, British colonial development policy after the Second World War: the case of Sukumaland, Tanganyika (Munster: LIT Verlag, 2010)

Bill Schwarz, Memories of empire, vol. I, The white man's world (Oxford: Oxford University Press, 2011)

Bill Schwarz: 'Unsentimental education: John Darwin's empire', Journal of Imperial and Commonwealth History, 43:1 (2015), 125-44

David Scott, 'Colonial governmentality', Social Text, 43:2 (1995), 191-220

David Scott, Refashioning futures: criticism after postcoloniality (Princeton, NJ: Princeton University Press, 1999)

David Scott, 'Norms of self-determination: thinking sovereignty through', Middle East Law and Governance, 4:2/3 (2012), 195-224

James C. Scott, Seeing like a state: how certain schemes to improve the human condition have failed (New Haven, CT: Yale University Press, 1998)

Michael Scott, Civilization in Africa (London: Fellowship of Reconciliation, 1952)

Anil Seal (ed.), Decline, revival and fall of the British empire (Cambridge: Cambridge University Press, 1982)

John Robert Seeley, The expansion of England: two courses of lectures (London: Macmillan, 1883)

Ronald Segal (ed.), Sanctions against South Africa (Harmondsworth: Penguin Books, 1964)

Todd Shepard, The invention of decolonization: the Algerian War and the remaking of France (Ithaca, NY: Cornell University Press, 2006)

Todd Shepard, Voices of decolonization: a brief history with documents (Boston, MA: Bedford/St Martins, 2015)

Martin Shipway, The road to war: France and Vietnam, 1944-1947 (Oxford: Berghahn Books, 1996)

Martin Shipway, 'Madagascar on the eve of insurrection, 1944-1947: the impasse of a liberal colonial policy', Journal of Imperial and Commonwealth History, 24:1 (1996), 72-100

Martin Shipway, Decolonization and its impact: a comparative approach to the end of the colonial empires (Malden, MA: Blackwell, 2008)

Martin Shipway, "'Transfer of destinies”, or business as usual? Republican invented tradition and the problem of "independence" at the end of the French empire', The Round Table, 97:398 (2008), 747-59

Peter Simon (ed.), Norton anthology of theory and criticism (New York: W. W. Norton, 2001)

A. W. Brian Simpson, Human rights and the end of empire: Britain and the genesis of the European Convention (Oxford: Oxford University Press, 2001)

Kate Skinner, 'Who knew the minds of the people? Specialist knowledge and developmentalist authoritarianism in postcolonial Ghana', Journal of Imperial and Commonwealth History, 39:2 (2011), 297-323

Robert Skinner, The foundations of anti-apartheid: liberal humanitarians and transnational activists in Britain and the United States, c. 1919-64 (Basingstoke: Palgrave Macmillan, 2010)

Robert Skinner and Alan Lester, 'Humanitarianism and empire: new research agendas', Journal of Imperial and Commonwealth History, 40:5 (2012), 729-47

Andrew W. M. Smith, 'Of colonial futures and an administrative Alamo: investment, reform and the loi cadre (1956) in French West Africa', French History, 28:1 (2014), 92-113

Andrew W. M. Smith, 'African dawn: Keïta Fodéba and the imagining of national culture in Guinea', Historical Reflections/Réflexions historiques (in press, 2017)

Anthony D. Smith, Ethno-symbolism and nationalism: a cultural approach (London: Routledge, 2009) 
John Smith (ed.), Administering empire: the British Colonial Service in retrospect (London: University of London Press, 1999)

Tom Soper, Aid management overseas (London: ODI Publications, 1967)

South African Democracy Education Trust, The road to democracy in South Africa, vol. I, 1960-1970 (Cape Town: Zebra Press, 2004)

Gabrielle M Spiegel, 'Historicism, and the social logic of the text in the Middle Ages', Speculum, 65:1 (1990), 59-86

Sarah Stockwell, The business of decolonization: British business strategies in the Gold Coast (Oxford: Oxford University Press, 2000)

Sarah Stockwell (ed.), The British empire: themes and perspectives (Oxford: Blackwell, 2008)

Ann Laura Stoler, Capitalism and confrontation in Sumatra's plantation belt, 1870-1979 (Ann Arbor, MI: University of Michigan Press, 1995)

Ann Laura Stoler, Along the archival grain: epistemic anxieties and colonial common sense (Princeton, NJ: Princeton University Press, 2009)

Ann Laura Stoler and Frederick Cooper (eds.), Tensions of empire: colonial cultures in a bourgeois world (Berkeley, CA: University of California Press, 1997)

Benjamin Stora, Histoire de la guerre d'Algérie, 1954-1962 (Paris: La Découverte, 2004)

Bertrand Taithe, 'Algerian orphans and colonial Christianity in Algeria, 1866-1939', French History, 20:4 (2006), 240-59

Ray Takeyh, The origins of the Eisenhower doctrine: the US, Britain and Nasser's Egypt, 1953-57 (New York: Palgrave Macmillan, 2000)

Sylvie Thénault, Histoire de la guerre d'indépendance algérienne (Paris: Flammarion, 2005)

Sylvie Thénault, Violence ordinaire dans l'Algérie coloniale: camps, internements, assignations à residence (Paris: Odile Jacob, 2012)

Ngũgĩ wa Thiong'o, Decolonising the mind: the politics of language in African literature (London: Heinemann Educational, 1986)

Martin Thomas, 'Colonial states as intelligence states: security policing and the limits of colonial rule in France's Muslim territories, 1921-40', Journal of Strategic Studies, 28:6 (2005), 1033-60

Martin Thomas, 'Albert Sarraut, French colonial development, and the communist threat, 1919-1930', Journal of Modern History, 77:4 (2005), 917-55

Martin Thomas (ed.), The French colonial mind, vol. I, Mental maps of empire and colonial encounters (Lincoln, NE: University of Nebraska Press, 2011)

Martin Thomas (ed.), The French colonial mind, vol. II, Violence, military encounters, and colonialism (Lincoln, NE: Nebraska University Press, 2011)

Martin Thomas, Violence and colonial order: police, workers and protest in the European colonial empires, 1918-1940 (Cambridge: Cambridge University Press, 2012)

Martin Thomas, Fight or flight: Britain, France, and their roads from empire (Oxford: Oxford University Press, 2014)

Martin Thomas, Bob Moore and Larry J. Butler, Crises of empire: decolonization and Europe's imperial states, 1918-1975, 2nd edn (London: Bloomsbury, 2015)

Martin Thomas and Andrew Thompson, "Empire and globalisation: from "high imperialism" to decolonization', International History Review, 36:1 (2014), 1-29, 142-70

Andrew Thompson, The empire strikes back? The impact of imperialism on Britain from the midnineteenth century (Harlow: Pearson Longman, 2005)

Andrew Thompson (ed.), Britain's experience of empire in the twentieth century (Oxford: Oxford University Press, 2011)

Kathryn Tidrick, Empire and the English character: the illusion of authority (London: Tauris Parke, 1990)

Romain Tiquet, 'Migrations protestataires et résistance au travail forcé en AOF, 1900-1946', Hommes et migrations, 1307 (2014), 166-9

Emmanuel Todd, Who is Charlie? Xenophobia and the new middle class (Cambridge: Polity, 2015)

Leo Tolstoy, War and peace (London: Penguin Books, 2005)

Jim Tomlinson, 'The decline of the empire and the economic "decline" of Britain', Twentieth Century British History, 14:3 (2003), 201-21

David Turner, The old boys: the decline and rise of the public school (New Haven, CT: Yale University Press, 2015)

Monica M. van Beusekom, Negotiating development: African farmers and colonial experts at the Office du Niger, 1920-1960 (Oxford: Heinemann, 2002)

Gabriel Vangrevelinghe, 'Les niveaux de vie en France, 1956 et 1965', Économie et statistique, 1:1 (1969), 7-21 
Richard Vinen, National Service: a generation in uniform 1945-1963 (London: Penguin Books, 2014)

Donald Wainwright, The volunteers: the story of overseas voluntary service (London: Macdonald, 1965)

Irwin M. Wall, France, the United States, and the Algerian War (Berkeley, CA: University of California Press, 2001)

Immanuel Wallerstein, Africa: the politics of independence and unity (Lincoln, NE: University of Nebraska Press, 2005)

Calder Walton, Empire of secrets: British intelligence, the Cold War and the twilight of empire (London: Harper, 2013)

David Waters, Letters from Abetifi (London: Minerva Press, 1999)

Stuart Ward (ed.), British culture and the end of empire (Manchester: Manchester University Press, 2001)

Joanna Warson, 'Entangled ends of empire: the role of France and francophone Africa in the decolonisation of Rhodesia', Journal of Colonialism and Colonial History, 16:1 (2015), doi: 10.1353/ cch.2015.0003

Wendy Webster, Englishness and empire 1939-1965 (Oxford: Oxford University Press, 2005)

Odd Arne Westad, The global Cold War: Third World interventions and the making of our times (Cambridge: Cambridge University Press, 2005)

Kenneth Clinton Wheare, The Statute of Westminster and dominion status (Oxford: Clarendon Press, 1938)

Nicholas J. White, 'Reconstructing Europe through rejuvenating empire: the British, French, and Dutch experiences compared', Past and Present, supplement 6 (2011), 211-36

Hannah Alice Whittaker, 'The socio-economic dynamics of the Shifta conflict in Kenya, 1963-8', Journal of African History, 53:3 (2012), 391-408

Gary Wilder, The French imperial nation-state: negritude and colonial humanism between the two world wars (Chicago, IL: University of Chicago Press, 2005)

Gary Wilder, Freedom time: negritude, decolonization, and the future of the world (Durham, NC: Duke University Press, 2014)

Peter Willetts, The Non-Aligned Movement: the origins of a Third World alliance (New York, NY: Nichols, 1978)

Randall Williams, Divided world: human rights and its violence (Minneapolis, MN: University of Minnesota Press, 2010)

Robin W. Winks (ed.), The Oxford history of the British empire, vol. V, Historiography (Oxford: Oxford University Press, 1999)

Daniel Yergin, The prize: the epic quest for oil, money and power (New York, NY: Free Press, 2008)

Crawford Young, The African colonial state in comparative perspective (New Haven, CT: Yale University Press, 1994)

Robert J. C. Young, Empire, colony, postcolony (Chichester: Wiley-Blackwell, 2015)

Andrew Zimmerman, 'Africa in imperial and transnational history: multi-sited historiography and the necessity of theory', Journal of African History, 54:3 (2013), 331-40

\section{Unpublished theses}

Roberto Cantoni, Oily deals: exploration, diplomacy and security in early cold war France and Italy (PhD thesis, University of Manchester, 2014)

Nile Gardiner, Sentinels of empire: the British Colonial Administrative Service, 1919-54 (PhD thesis, Yale University, 1998)

Martine Mougin, L'Afrique a l'école depuis 1945 jusqu'à la fin des années 90 (PhD thesis, Université Lumière Lyon 2, 2005)

Charlotte Lydia Riley, Monstrous predatory vampires and beneficent fairy-godmothers: British postwar colonial development in Africa (PhD thesis, University College London, 2013) 


\section{Index}

African National Congress (ANC) 117-18, 119, 120, 123; Umkhonto we Sizwe (MK) 118,122

alchemical humanitarianism 127

Algeria 1, 8, 63, 69, 71, 73, 82, 95, 96, 100; Algerian Development Fund 80; Algiers 70; Association Coopérative (Ascoop) 82; colonial violence 38; El Moudjahid 76, 77, 78, 79; French colonial rule 69, 101, 109; Hassi Messaoud 68, 74, 80, 81; Oasis 71; oil 74, 77, 81, 83; Organisme technique de coopération saharienne 81; Philippeville 74; Saoura 71

Algerian War 21, 99, 173; battle of Algiers 7, 62; Constantine Plan 75, 184; Évian Accords $63,76,79-81,82$; oil industry $63,72,76$, $79,80,83$

Algiers Charter of Economic Rights for the Third World 127

Amnesty International 115, 117-18, 129 anti-apartheid movement 11; Anti-Apartheid Movement (AAM) 118, 123, 126, 128; Barclay's Bank campaign 128; Cold War 116, 130; human rights 112, 119; International Defence and Aid Fund (IDAF) 115, 120, 123, 125, 129; South Africa 115, 119; transnational networks 112, 115, 118, 119, 121, 123, 129, 130; United Kingdom 111, 116, 128; United Nations 122; World Campaign for the Release of South African Political Prisoners (WCRSAPP) 118-21, $123,124,125,126,128$

anti-colonial movements 5, 14, 17, 26, 101, 102, 172; Afrique Équatoriale française (AEF) 102, 156; agency 18; Cold War 5, 6; colonial repression 39; FLN (Algerian National Liberation Front) 7, 72-81; horizons of expectation 10; human rights 114, 122, 129; Mozambique 29; nationalism 27, 28, 29, 33, 162; transnational networks 28, 113, 117, 123, 128, 179

anti-Vietnam-War campaign 112

Atlantic Charter (1941) 6

Attlee, Clement 147

Baker, Eric 117

Bandung Conference (1955) 125
Basutoland see Lesotho Bechuanaland see Botswana Ben Bella, Ahmed 72

Benenson, Peter 115, 117

Benin 158, 161, 167

Benjamin, Walter 179

Bisson, Robert 82

Blum, Leon 21

Botswana 117, 152

Bourdet, Claude 83

Boye, Ibrahima 126

Bradley, Sir Kenneth 133, 134, 137, 140

Brazzaville Conference (1944) 21, 105, 106, 156, 160, 180

Britain; angry young men 142, 146; Attlee government (1945-51) 49, 50, 52, 53; Blair government (1997-2001) 59; changing career patterns 145; Colonial Office 48, 53, 114, 116, 141, 150, 165; Commonwealth Relations Office 54; Conservative Party 51, 54; ethical foreign policy 60 ; Foreign Office 53, 54, 59; impact of decolonization 135; Labour Party 7, 43-61, 173, 183; national service 145; sterling area 46; Thatcher government (1979-90) 60; Wilson government (1964-70) 54, 56, 57, 59

Britain, Colonial Service 13, 137; developmental turn 138, 139, 141; ethos 133, 134, 138, 139, 140-3, 146, 149, 154; recruitment $133,138,144,145,146,148$, 151, 153, 174, 183; training 141; Voluntary Service Overseas (VSO) 149, 150, 151

Britain, development; Colonial Development Act (1929) 43, 47, 59; Colonial Development and Welfare Act (1940) 43, 47, 49; Colonial Development and Welfare Act (1945) 48; Colonial Development and Welfare Acts, renewal 54; Colonial Development Corporation (CDC) 53, 54; Colonial Development Fund 48; Colonial Economic and Development Council 48; Colonial Office 52, 53, 137, 151, 161; Commonwealth, the 54, 55, 58, 151 ; community development 149,150 ; Department for International Development (DFID) 43, 59, 60; Department of Technical 
Co-operation (DTC) 54; international aid 44, 54, 59; international development 55, 57; Overseas Development Institute (ODI) 47, 58; Overseas Development Ministry (ODM) 43, 54, 56, 57-9; Overseas Food Corporation (OFC) 53

British Council 151-2

Brutus, Dennis 120, 123

Burkina Faso 158

Butler, R. A. 116-17

Câmara, Archbishop Dom Hélder 127

Cartier, Raymond 92-4, 98

Castle, Barbara 55, 56-8, 59

Césaire, Aimé 184

Chad 71

Chadwick, Edward 150

Chamberlain, Joseph 52

China 25, 179

Christian Aid 126

civilizing mission $6,19,22,43,46,93,98,99$, 102, 105, 133

Cohen, Sir Andrew 21

Cold War 32, 34, 57, 63, 172

Cole, Margaret 49

Collins, Canon John 115

colonial administrators 9, 20, 39, 105, 134, 139, 144, 163, 164, 168, 170, 175

colonial futures 7, 9, 44, 71, 88-90, 91, 98, 107-8, 110, 157, 160, 170, 172, 173, 175 colonial labour strikes 51

Commonwealth, the 133, 140, 141, 147, 150

Communauté see French Community

Congo 21

Cornet, Pierre 70, 71

Cornut-Gentille, Bernard 103, 104, 106-8

Côte d'Ivoire 158

Creech Jones, Arthur 21, 48, 49, 50, 51-3, 59,138

Dahomey see Benin

de Blank, Archbishop Joost 122

de Gaulle, Charles 74, 75, 80, 90, 105, 162,184

developmental turn 8, 14, 44, 45, 46, 47-9, 51, 53, 138, 149

Dickson, Alec 148-51, 152, 154

Dien Bien Phu 88, 91, 103, 181 see Indochina

Dillon, Clarence Douglas 72

Driberg, Tom 55

Duce, James 72

education 109; Afrique Équatoriale française 95-103; British grammar schools 145-6; British public schools 143, 146-8, 149, 151; civilizing mission 22; mass education 143 , 149; university appointments boards 145

Ennals, John 123
Eurafrica 63, 69-70, 82, 84

Eurocentrism 18, 23, 26, 40

European Economic Community 62, 69

Fabianism 48, 50, 53, 58; Fabian Colonial Bureau (FCB) 49-53; Fabian Society 49

Fanon, Frantz 29, 33, 93

federalism 29-33, 112, 172, 181, 183

First, Ruth 123

Foccart, Jacques 108

Fodéba, Keïta 10, 172, 176

Foucault, Michel 183, 184

France; Foreign Office see Quai d'Orsay; loi cadre (1956) 95, 103, 106; Minister of the Sahara 71; Ministry of Overseas France 91, 165, 168, 169; Ministry of the Colonies see Ministry of Overseas France; National Assembly 163; oil industry 63, 67-75; Popular Front government 159; Quai d'Orsay 160, 165, 167, 168; Service de documentation extérieure et de contreespionnage (SDECE) 78

France, development; Bureau d'organisation des ensembles industriels africains (BIA) 69; Bureau de recherche de pétrole (BRP) 67, 71-2, 73, 75, 80; comité des Zones d'Organisation industrielle africaine (ZOIA) 70; European consortium for the development of African natural resources 69; Organisation commune des régions sahariennes (OCRS) 70-1, 74, 75, 77, 80, 184

French Community 8, 18, 21, 96, 181

French Fourth Republic 93, 105;

collapse 74, 90

French Soudan see Mali

French Union 21, 30, 70, 71, 87, 88, 90-5, $98,99,100-1,106-8,161,166,167,168$, 169, 181

Furse, Sir Ralph 138-9, 153, 154

Ganji, Manouchehr 122

Gardiner, Gerald 115

Ghana 27, 32, 55, 57, 152, 158-71; Accra 160, 162, 169-70; Accra riots (1948) 161 ; French involvement in 163-9; labour migration 158-63

Gold Coast see Ghana

Great Depression 47

Guillaumat, Pierre 67, 73

Guinea-Bissau 29

Hanslope Park 109

Hart, Judith 58

Hartley Report, the (1956) 65

Haslemere Declaration 126-8, 130

Hinden, Rita 48, 49, 50, 52

Horrabin, Frank 49 
Huddleston, Trevor 127

human rights $11,14,49,111-15,116,119$, 174; armed struggle 124; Cold War 112; Commonwealth, the 116, 117; development 8, 125, 126; European Convention on Human Rights 113; grass-roots advocacy 117; individual rights 127; International Commission of Jurists 115, 119; Poverty is violence conference (1968) 127; race 115; self-determination $6,113-15,120$, 126, 129, 183; transnational networks 118; United Nations 120-1, 125

Hutchinson, Robert 128

imperial nation state $3,5,10,11,13,22,95$, 174, 176 see nation state

India 19, 46, 115; Indian Civil Service 138,145

Indochina $87,88,90-2,101,109,180,181$; Indochinese War 21, 90, 95, 100 see Dien Bien Phu

Italy; oil policy $76,80-1$

Ivory Coast see Côte d'Ivoire

Keatley, Patrick 123

Kennedy, John F. 73

Kenya 8, 27, 29, 31, 52; Hola camp massacre (1959) 116; Mau Mau emergency 23, 29, 38, 154

Krim, Belkacem 80

\section{Labonne, Erik 70}

Lacoste, Robert 72

late colonial shift $2,5,6,14,136,160,172$, $175,178,182$

late colonial state $4,7,11,14,25,33-41,89$, 96, 99, 105, 108, 109, 116, 120, 136, 143, $148,174,181-5$

Laurentie, Henri 91, 94, 165, 180-1

Lennox-Boyd, Alan 151

Lesotho 117

Lewis, W. Arthur 49

Leys, Norman 50

MacDonald, Malcolm 47

Macmillan, Harold 1, 57, 117, 136, 178

Maghreb Union 77

Mali 71, 158, 184

Mandela, Nelson 117, 118

Matthews, Joe 123

McCleery, H. H. 144, 153

Minty, Abdul 123-4

mission civilisatrice see civilizing mission

Mitchell, Andrew 60

Mollet, Guy 69, 70, 71, 72

Morocco 72, 77, 80, 101

Mozambique 29

Mus, Paul 87, 88, 90-5, 98, 106, 107, 181, 185
Namibia 115

Nasser, Gamal Abdel 62, 77

nation state 2, 26, 33-41, 46, 61, 110, 157,

185, 201 see imperial nation state

National Assembly (France) 163

Niger 71, 158, 166, 184

Nigeria 46, 150, 161, 169; French involvement in 166-9; labour migration 161, 162; Lagos $161,164,165$

Nkrumah, Kwame 1, 161, 162, 169

Non-Aligned Movement 78, 124

North Atlantic Treaty Organization (NATO) 44

Northern Rhodesia see Zambia

Nyerere, Julius 31, 127

official mind 179

oil industry 66, 72, 73; Arabian-American Oil Company (Aramco) 72-3; British Petroleum 66; CAMEL 81; Cities Service Company 74; Cold War 64, 67; Compagnie de recherche and d'exploitation de pétrole au Sahara (CREPS) 78; Compagnie Française de Pétrole (CFP) 67, 74, 75; ENI 80-1, 82; European energy demands 64, 65; Gulf Oil 66; international development 78, 81; Iran 75; Middle East, the 62, 65, 67, 72; Newmont Mining 74; Petroleum Press Service 77; Pétropar 75; Phillips Petroleum 74; Régie autonome des pétroles (RAP) 67; Royal Dutch Shell 66, 67; 'Seven Sisters' 62; Sinclair Oil 67, 74; SN REPAL 67, 74; Socony Mobil 66; SONATRACH 81, 82; Standard Oil of California 66, 72, 74, 78, 82; Standard Oil of New Jersey 66; state-owned enterprises (SOEs) 66, 80; Texaco 66; Tunisia 7, 78, 80; United States of America 65; Venezuela 65, 75, 78

Organisation for European Economic Cooperation (OEEC) 64

Organisation of African Unity 129

Organization of the Petroleum Exporting Countries (OPEC) 82

overseas voluntarism 135, 148, 150, 152; Voluntary Service Overseas (VSO) 56, 137, 155, 174

Oxfam 56, 126

pan-Africanism 28, 30, 32

Perham, Margery 20, 49

pieds noirs 22, 95-7, 102

Pineau, Christian 71, 73

Pirani, Mario 80

Portugal 29, 123, 124

Prentice, Reginald 55

Resha, Robert 123

Rhodesia see Zimbabwe 
Sahara; Edjeleh oil field 68, 70, 78; French energy policy 68, 69-75, 83; mineral deposits 69; oil exploration 7, 62-3, 67, 70; oil extraction 71-9, 81, 84; oil industry 63 , 71-4, 76; sovereignty 73, 76, 79-81, 82, 83 Sampson, Anthony 153

Sarawak 152, 153

Sarraut, Albert 98-9, 101

Saud, King (Saud bin Abdulaziz Al Saud) 72

Saudi Arabia 73

Scott, Rev. Michael 126

Seale, Bobby 127

Senegal 165; Dakar 21, 161, 165, 166

Senghor, Leopold 3-4, 8, 108, 184

Singapore 25

Six-Day War (1967) 82

South Africa 46, 57, 124; apartheid 111, 113, 114, 118-19, 120, 121, 123; exit from the Commonwealth (1961) 117; international opposition 115; Rivonia Trial (1963-64) 119; Sharpeville massacre (1960) 116-17, 120; South Asian community 115; Treason Trial (1956-61) 115

South-West Africa see Namibia sovereignty $59,61,173,175$; human rights $111,112,114,120,123,129$; nation state 31, 42, 184-5; self-determination 31 , 79 , 123; transfer of power 2, 51, 79, 124

Soviet Union 64, 65, 69

Stanley, Oliver 138

Steel, David 123

Stephenson, Gilbert 150, 151

Strachey, John 53

Sudan Political Service 138

Suez Canal Company 62

Suez Crisis 4, 7, 68, 146

Swaziland 117

Tambo, Oliver 118

Tanganyika see Tanzania

Tanzania 45; Arusha Declaration (1967) 127; East African Groundnuts Scheme 53
Togo 158, 169

Tolstoy, Leo 177-8

Touré, Sekou 10

trade unionism 52

Tuareg 69, 184

Tunisia 72, 77, 79, 80; Gabés 78

Uganda 30, 31

United Nations 44, 57, 112, 114, 124; Brasilia Human Rights Seminar on Apartheid (1966) 120; Commission on Human Rights 126; Development Decade 56; International Conference on Human Rights (1967) 121; International Conference on Human Rights (1968) 122; International Covenant on Economic, Social and Cultural Rights (1966) 124; International Day for the Elimination of Racial Discrimination (1967) 120; International Year for Human Rights (1968) 121; Kitwe seminar on apartheid (1967) 121; Special Commission on Human Rights 121; Special Committee on Apartheid 115, 120; Special Political Committee of the General Assembly 118; Trusteeship Committee 115; Universal declaration of human rights (1948) 6, 121, 125, 127

United States of America 24, 25, 32, 34, 69,73

Upper Volta see Burkina Faso

utopianism 11, 101, 112-13, 114, 134

Verwoerd, Hendrik 116, 117

West African labour migrancy 13, 156-71, 175

Woolf, Leonard 49

Zambia 153

Zeno's paradox; Achilles and the tortoise 177-80, 181, 185

Zimbabwe 29, 30, 122, 123, 124; Zimbabwe African Peoples' Union 122 
Looking at decolonization in the conditional tense, this volume teases out the complex and uncertain ends of British and French empire in Africa during the period of 'late colonial shift' after 1945. Rather than view decolonization as an inevitable process, the contributors together explore the crucial historical moments in which change was negotiated, compromises were made, and debates were staged. Three core themes guide the analysis: development, contingency and entanglement. The chapters consider the ways in which decolonization was governed and moderated by concerns about development and profit. A complementary focus on contingency allows deeper consideration of how colonial powers planned for 'colonial futures', and how divergent voices greeted the end of empire. Thinking about entanglements likewise stresses both the connections that existed between the British and French empires in Africa, and those that endured beyond the formal transfer of power.

Andrew W.M. Smith is Teaching Fellow at UCL and the Secretary of the Society for the Study of French History. His work focuses on concepts of centre and periphery, analysing various contexts in which this relationship has shaped developments within and beyond the structures of the modern state.

Chris Jeppesen is Teaching Fellow at UCL. His work focuses on the shifting place of empire within British culture, in particular in the period after the Second World War. 